\title{
Jean-Baptiste Say and the Classical Canon in Economics
}

This book explores the commonly-perceived paradigmatic conflict between the 'Ricardo School' and the contemporary French economics of JeanBaptiste Say.

Samuel Hollander provides the reader with extensive evidence, utilising all editions of Say's main texts and his lesser-known writings, demonstrating Say's adherence to much of Ricardian economics. The book focuses on methodology, selected doctrinal issues and the surrounding debates, including:

- value and distribution with extension to growth theory

- real income and its measurement with implications for trade and taxation

- the 'Law of Markets'

This intriguing book will interest all serious historians of economic thought and will find a place on the bookshelves of many economists across the world.

Samuel Hollander is University Professor Emeritus, University of Toronto, and Professor of Economics at Ben Gurion University in Israel. He is an Officer in the Order of Canada. 


\section{Routledge Studies in the History of Economics}

\author{
1 Economics as Literature \\ Willie Henderson \\ 2 Socialism and Marginalism in \\ Economics 1870-1930 \\ Edited by Ian Steedman \\ 3 Hayek's Political Economy \\ The socio-economics of order \\ Steve Fleetwood
}

4 On the Origins of Classical Economics Distribution and value from William Petty to Adam Smith

Tony Aspromourgos

5 The Economics of Joan Robinson

Edited by Maria Cristina Marcuzzo,

Luigi Pasinetti and Alesandro Roncaglia

6 The Evolutionist Economics of Léon Walras

Albert Jolink

7 Keynes and the 'Classics'

A study in language, epistemology and mistaken identities

Michel Verdon

8 The History of Game Theory, Vol 1

From the beginnings to 1945

Robert W. Dimand and Mary Ann Dimand

9 The Economics of W. S. Jevons

Sandra Peart

10 Gandhi's Economic Thought

Ajit K. Dasgupta

11 Equilibrium and Economic Theory

Edited by Giovanni Caravale

12 Austrian Economics in Debate

Edited by Willem Keizer, Bert Tieben and Rudy van Zijp

13 Ancient Economic Thought Edited by B. B. Price

14 The Political Economy of Social Credit and Guild Socialism

Frances Hutchinson and Brian Burkitt
15 Economic Careers

Economics and economists in Britain

1930-1970

Keith Tribe

16 Understanding 'Classical' Economics Studies in the long-period theory

Heinz Kurz and Neri Salvadori

17 History of Environmental Economic Thought

E. Kula

18 Economic Thought in Communist and Post-Communist Europe

Edited by Hans-Jürgen Wagener

19 Studies in the History of French

Political Economy

From Bodin to Walras

Edited by Gilbert Faccarello

20 The Economics of John Rae

Edited by O. F. Hamouda, C. Lee and D. Mair

21 Keynes and the Neoclassical Synthesis

Einsteinian versus Newtonian macroeconomics

Teodoro Dario Togati

22 Historical Perspectives on

Macroeconomics

Sixty years after the 'General Theory'

Edited by Philippe Fontaine

and Albert Jolink.

23 The Founding of Institutional

Economics

The leisure class and sovereignty

Edited by Warren J. Samuels

24 Evolution of Austrian Economics

From Menger to Lachmann

Sandye Gloria

25 Marx's Concept of Money: the God of Commodities

Anitra Nelson

26 The Economics of James Steuart

Edited by Ramón Tortajada 
27 The Development of Economics in Europe since 1945

Edited by A. W. Bob Coats

28 The Canon in the History of

Economics

Critical essays

Edited by Michalis Psalidopoulos

29 Money and Growth

Selected papers of Allyn Abbott Young

Edited by Perry G. Mehrling

and Roger J. Sandilands

30 The Social Economics of Jean-

Baptiste Say

Markets \& virtue

Evelyn L. Forget

31 The Foundations of Laissez-Faire

The economics of Pierre de Boisguilbert Gilbert Faccarello

32 John Ruskin's Political Economy Willie Henderson

33 Contributions to the History of

Economic Thought

Essays in honour of R. D. C. Black

Edited by Antoin E Murphy and Renee

Prendergast

34 Towards an Unknown Marx

A commentary on the manuscripts of

1861-63

Enrique Dussel

35 Economics and Interdisciplinary

Exchange

Edited by Guido Erreygers

36 Economics as the Art of Thought

Essays in memory of G. L. S. Shackle

Edited by Stephen F. Frowen and Peter Earl

37 The Decline of Ricardian

Economics

Politics and economics in Post-Ricardian theory

Susan Pashkoff

38 Piero Sraffa

His life, thought and cultural heritage

Alessandro Roncaglia

39 Equilibrium and Disequilibrium in

Economic Theory

The Marshall-Walras divide

Michel de Vroey
40 The German Historical School

The historical and ethical approach to economics

Edited by Yuichi Shionoya

41 Reflections on the Classical Canon in Economics

Essays in honor of Samuel Hollander

Edited by Sandra Peart and Evelyn Forget

42 Piero Sraffa's Political Economy

A centenary estimate

Edited by Terenzio Cozzi and Roberto

Marchionatti

43 The Contribution of Joseph

Schumpeter to Economics

Economic development and institutional change

Richard Arena and Cecile Dangel

44 On the Development of Long-run

Neo-Classical Theory

Tom Kompas

45 F. A. Hayek as a Political Economist Economic analysis and values

Edited by Jack Birner, Pierre Garrouste

and Thierry Aimar

46 Pareto, Economics and Society

The mechanical analogy

Michael McLure

47 The Cambridge Controversies in Capital Theory

A study in the logic of theory development Jack Birner.

48 Economics Broadly Considered Essays in honor of Warren J. Samuels Edited by Steven G. Medema, Jeff Biddle and John B. Davis

49 Physicians and Political Economy Six studies of the work of doctor-economists Edited by Peter Groenewegen

50 The Spread of Political Economy and the Professionalisation of Economists Economic societies in Europe, America and Japan in the Nineteenth Century Massimo Augello and Marco Guidi

51 Historians of Economics \& Economic Thought

The construction of disciplinary memory

Steven G. Medema and Warren J. Samuels 
52 Competing Economic Theories

Essays in memory of Giovanni

Caravale

Sergio Nisticò and Domenico Tosato

53 Economic Thought and Policy in

Less Developed Europe

The 19th Century

Edited by Michalis Psalidopoulos and

Maria-Eugenia Almedia Mata

54 Family Fictions and Family Facts

Harriet Martineau, Adolphe Quetelet

and the population question in England

1798-1859

Brian Cooper

55 Eighteenth-Century Economics

Peter Groenewegen

56 The Rise of Political Economy in the Scottish Enlightenment

Edited by Tatsuya Sakamoto and Hideo Tanaka

57 Classics and Moderns in Economics

Volume I

Essays on nineteenth and twentieth century economic thought

Peter Groenewegen

58 Classics and Moderns in Economics Volume II

Essays on nineteenth and twentieth century economic thought

Peter Groenewegen

59 Marshall's Evolutionary Economics Tiziano Raffaelli

60 Money, Time and Rationality in

Max Weber

Austrian connections

Stephen D. Parsons

61 Classical Macroeconomics

Some modern variations and distortions James C.W. Abiakpor

62 The Historical School of Economics in England and Japan

Tamotsu Nishizawa
63 Classical Economics and Modern

Theory

Studies in long-period analysis

Heinz D. Kurz and Neri Salvadori

64 A Bibliography of Female Economic Thought to 1940

Kirsten K. Madden, Janet A. Sietz and Michele Pujol

65 Economics, Economists and Expectations

From microfoundations to

macroeconomics

Warren Young, Robert Leeson and William

Darity Jnr.

66 The Political Economy of Public Finance in Britain, 1767-1873

Takuo Dome

67 Essays in the History of Economics Warren J. Samuels, Willie Henderson,

Kirk D. Johnson and Marianne Johnson

68 History and Political

Economy

Essays in honour of P. D. Groenewegen

Edited by Tony Aspromourgos and John

Lodewijks

69 The Tradition of Free Trade

Lars Magnusson

70 Evolution of the Market

Process

Austrian and Swedish economics

Edited by Michel Bellet, Sandye Gloria-Palermo and Abdallab Zouache

71 Consumption as an Investment The fear of goods from Hesoid to Adam Smith

Cosimo Perrotta

72 Jean-Baptiste Say and the Classical Canon in Economics

The British connection in French

classicism

Samuel Hollander 


\section{Jean-Baptiste Say and the Classical Canon in Economics}

The British connection in French classicism

Samuel Hollander 
First published 2005 by Routledge

Published 2017 by Routledge

2 Park Square, Milton Park, Abingdon, Oxon OX14 4RN

711 Third Avenue, New York, NY 10017, USA

Routledge is an imprint of the Taylor \& Francis Group, an informa business

Copyright (C) 2005 Samuel Hollander

Typeset in Garamond by

Taylor \& Francis Books

The Open Access version of this book, available at www.tandfebooks. com, has been made available under a Creative Commons Attribution -Non Commercial-No Derivatives 4.0 license.

British Library Cataloguing in Publication Data

A catalogue record for this book is available from the British Library

Library of Congress Cataloging in Publication Data

A catalog record for this book has been requested

ISBN 978-0-415-32338-3 (hbk) 
Dedicated to Paul A. Samuelson 
James Mill to Say, 25 February 1817:

'My dear and never to be forgotten friend ...';

Mill to Say, 28 May 1825: 'My dear Sir ...'

(Heertje 1971) 


\section{Contents}

Preface

1 Introduction

The classical canon 1

The Ricardo-Say relation: a review of the literature 15

Plan of work 23

2 Value, distribution and growth before 1823

Say's cost-price analysis 180325

Cost-price analysis 1814-17 26

The Notes (1819) on Ricardo's Principles: cost price 30

The Notes (1819) on Ricardo's Principles: rent 46

Modifications to the Traité 181955

A further modification: the falling rate of interest and the inverse profit-wage relation 64

The 'subsistence' wage and population size 67

The utility dimension 70

The Say-Ricardo correspondence 1820-2: approaching accord on value theory 75

3 Value, distribution and growth after 1823

Cost-price analysis 86

Pricing and 'utility' 97

Service-supply conditions 106

The earnings structure 119

Land-based limits to growth, the falling wage path and the stationary state 122

The falling rate of interest 128

Summary: Say's representation of Ricardo 129 
4 On 'riches': real income and its measurement

Introduction 144

The early Say-Ricardo exchange 1815145

'Riches' as real-income flow: the case elaborated 146

The late Say-Ricardo exchange 1821-2 156

Post-1823 statements 158

Malthus on Say and 'riches' 165

Capital accumulation: productive and unproductive consumption 170

On surplus: gross and net revenue 177

Taxation and economic activity 179

The gains from trade 184

Summary and conclusion 185

\section{The Law of Markets}

Introduction 189

Say's first statement, 1803189

The evolution of Say's position: general excess supply and the problem of 'counter-commodities' 194

The interpretation of contemporary depression 203

'Limits to production': the Law of Markets recanted? 212

The Law of Markets and Say's entrepreneur 214

Questions of priority: Say and James Mill 219

Summary and conclusion 222

6 Say and the classical canon: an overview

Jobn Stuart Mill's conciliatory position 226

Methodology 227

Doctrine 250

Say and the canonical growth model 254

Internal paradigmatic conflicts 258

\section{Conclusion}

The impression of systemic discord 262

Say's increasing bostility 266

An bypothesis 276

Appendix I Say's Notes on Ricardo's Principles

Appendix II On Say's charges against McCulloch of plagiarism 287

Appendix III McCulloch's review of Say 1821 (1819a) 289

Notes 293

Bibliography $\quad 311$

Index 


\section{Preface}

This study does not seek to provide a comprehensive analysis of Say's economics in the manner of my elephantine volumes on Ricardo, Mill and Malthus. Nor does it take account of Say's social philosophy and intellectual milieu, in the manner of Palmer (1997), Forget (1999) and several essays in Potier and Tiran (2003). I focus rather on select doctrinal issues and the debates surrounding them: value and distribution with extensions to growth theory; 'riches' in the sense of real income and its measurement with implications for trade and taxation; and the 'Law of Markets'. Matters relating to Say's methodology, in principle and in practice, are taken up in the course of a concluding overview.

Some two decades ago, inspired by a film of the day, I chose 'The French Connection in British Classicism' as the subtitle for a lecture on the substantive identity of the Ricardian and neo-classical conceptions of economic organisation (Hollander 1982). My interpretation of Ricardo has been the subject of extensive debate and it would not be sensible to rehearse in detail the exegetical and logical grounds on which it is based. Nonetheless, some readers might find it convenient to have on hand a brief summary of that interpretation. This I provide in the Introduction with particular attention to matters that will prove pertinent to the body of the work, a procedure that will reduce the force of any charge that might otherwise be directed against me that I proceed entirely by assertion. Having said this, I do believe that the documentation provided in this volume not only makes Say more comprehensible in his own right, but adds to the evidence favouring my view of Ricardo's economics. Say, for example, in his important Notes to Ricardo's Principles committed himself to the falling rate of profit in consequence of increase in wage-goods costs, and admitted that Smithian increasing competition of capitals clashed with the Law of Markets perspective. He also came to appreciate the demand component in the Ricardian approach to value and growth. Furthermore, his doctrine of services was understood by Ricardo, by Malthus, and indeed by Say himself, to be a restatement of orthodox cost theory; while his circular-flow orientation precluded neither an 'advances' conception of capital including the wages component nor the classical proposition relating to accumulation that 'demand for commodities is not demand for labour'. I am 
inclined, in the light of these and similar results, to refer to a 'British Connection in French Classicism'. Furthermore, Say's economics emerges as firmly in the 'deductive' tradition - and to a greater degree than is usually supposed - contributing further to the common ground.

I do not argue, however, that there evolved an identity of position. Despite the canonical features mentioned above, Say retained others inconsistent with the canon. I have in mind, in particular, a Smithian adding-up-costs approach whereby increase in the general wage raises prices, which conflicts with the inverse wage-profit relation; Smithian investment priorities - including the peculiar significance attached to agriculture - which imply systematic deviations between social and private returns and conflict with standard allocation theory, as Ricardo insisted; and historical constancy of the corn price explained in terms of the population mechanism whereby increase in corn supply generates corresponding increase in corn demand again at odds with demandsupply analysis. Furthermore, Smithian competition of capitals remains on the books despite the admission of its untenability. These happen to be the matters on which Malthus, equally inconsistent, deviated from the canon. On the other hand, we shall find that Say frequently adopted a stronger version of the subsistence-wage doctrine than did either Ricardo or Malthus; and by incorporating allowance for new technology and free trade he formulated an empirical version of diminishing returns, contrasting with the standard analytical version of the canonical model. I note that in an investigation of materials touching on the Say-Ricardo relation, Professors Gehrke and Kurz have posited their intention '[w] henever possible [to] let the authors speak for themselves' (Gehrke and Kurz 2001: 485-6). I applaud the design and try to follow it myself, but suspect that we may not have been tuned into the same wavelength.

I commenced this study in France at LATAPSES (Centre National de la Recherche Scientifique and Université de Nice-Sophia Antipolis) during my tenure there as Directeur de Recherche 1999-2000 and continued my investigation early in 2002 under the same auspices. The substance of my argument on the Say-Ricardo nexus in so far as it relates to the theory of value was presented at the Conference on 'British and Continental Traditions on Classical Political Economy’ organized by Professor Richard Arena, Dr Agnes Festré and myself, held at Sophia Antipolis, France, 13-14 December 2001 under the sponsorship of LATAPSES-IODE.

It is a pleasure to acknowledge both the financial and research support provided by the CNRS and the Universite de Nice, and the initiatives taken by Professor Arena regarding my appointments. My obligations to Professor Arena are very great indeed, for it is he who persuaded me to widen the scope of my long-standing project on classical economics. I am also indebted to him and to Professor André Lapidus (Université de Paris I) for initiating my personal French connection. The standard proviso of course applies, but I do not doubt that this book is the better for the wise counsel I was fortunate to receive from Professor Philippe Steiner 
(Université de Paris IX) and Professor Tom Kompas (Australian National University). Dr Tim Davis, Dr Karine Goglio and Dr Rafael Gomez have kindly helped with documentation and I am once again in Professor Steiner's debt in this regard too.

My research programme has been supported by the Department of Economics, Ben-Gurion University of the Negev, Be'er Sheva, Israel. A friendly environment, splendid facilities and generous research funding have proven a godsend - as is perhaps appropriate in this part of the world. The efficient services of the inter-library loan department at the Aranne Library have also facilitated my task.

It remains for me to express my wonderment at the willingness of three secretaries to deal with a complex bilingual document - Claudine Renzacci (Nice) who knows no English, and Norma Rankin (Ottawa) and Estelle Shulgasser (Be'er Sheva) who know no French. My wife Perlette came to my rescue at the proof-reading stage - but then she is French.

$$
* * *
$$

In my citations I reproduce Say's original, sometimes archaic, spelling but correct his frequent omission of accents in his letters to Ricardo. References to his Notes on Ricardo's Principles are to the original text of 1819 , but the punctuation is sometimes that of later editions.

Be'er Sheva, Israel

May 2004 



\section{Introduction}

\section{The classical canon}

This book is concerned with the frequently-encountered notion of a paradigmatic clash between the economics of Jean-Baptiste Say and of David Ricardo, and with the more specific claim that after Ricardo's death in 1823 Say's opposition hardened. I demonstrate to the contrary that despite his attribution to Ricardo of extreme positions regarding doctrine and method, Say's adherence to much of Ricardian theory - the cost dimension to value theory in particular and major elements of the growth doctrine - emerges throughout his writings; and that it is even reinforced in the 1826 edition of the Traité d'économie politique, and in the Cours complet (1828-9). The Introduction, drawing on Hollander (2001), lays out the themes constituting the 'classical' or Ricardian canon, provides a review of the secondary literature on the Ricardo-Say relation and establishes the plan of work.

\section{The pure analytics}

In considering the pure analytics of classicism (Ricardianism) I focus on growth, distribution and value theory, in effect the 'real' dimension; and the theory of aggregate activity. Where to start is somewhat arbitrary, considering the interdependencies involved.

\section{Elements of growth theory}

The essence of Ricardo's growth theory lies in its perception of the average real wage or, in the simplest models, the average corn wage, as a marketdetermined variable which, because of the land-scarcity constraint and in the absence of prudential population control, is subject - along with the profit (interest) rate - to downward secular pressure. The proximate cause of the falling real wage is the deceleration in capital accumulation (and thus in aggregate labour demand) imposed by increasing land scarcity, since '[the] motive for accumulation will diminish with every diminution of profits' (Ricardo 1951-73, 1: 122). Whether or not the wage decline is steep or 


\section{Introduction}

shallow, rapid or slow, the essential feature of the model is the necessarily simultaneous decline of the profit and wage rates, or the shared incidence of the falling marginal product of variable labour-cum-capital on fixed land. (Rent in this model is treated as a differential surplus, a position that implicitly assumes one-use land.) As for the 'subsistence' wage, that rules in the stationary state alone - the end-point of the growth process - and is reached simultaneously with that profit rate corresponding to zero net capital accumulation:

If . . wages were regulated by a yearly increase of capital, at the rate of 2 per cent., they would fall when it accumulated only at the rate of $1-1 / 2$ per cent. They would fall still lower when it increased only at the rate of 1 , or $1 / 2$ per cent., and would continue to do so until the capital became stationary, when wages also would become stationary, and be only sufficient to keep up the numbers of the actual population.

Thus, although the corn wage is falling, the burden of diminishing returns cannot be entirely shifted on to labour insulating the profit rate from decline. The logic of the matter is that the fall in the corn wage is necessarily smaller than that of the marginal product so that the wage share, or proportionate wages, rises. And it is proportionate wages that govern the profit rate. This is an application of the inverse wage-profit relation.

\section{The inverse wage-profit relation and the labour theory of value}

The inverse relation thus far has been expressed in terms of corn. But Ricardo also translated into money values (his chapter 1, passim). In the simple case where agricultural produce and money, the manufactured commodity 'gold', are produced by technologies entailing the same 'labour'-'capital' ratios (or the time labour is invested), then a labour theory of value will be applicable, for in that case changes in the wage leave relative gold prices unaffected, prices varying uniquely in proportion to labour embodiment; and if we further suppose the labour embodiment in gold to be constant while that in corn rises secularly with diminishing returns, than the gold value of a unit of corn rises precisely to reflect agricultural labour's reduced productivity. This in turn means that the gold value of the output of given labour is constant, the rise in the corn price compensating precisely for the fall in output whatever the magnitude of the output might be.

In terms of such reasoning involving a 'gold' measure of value - in effect a labour measure - the earlier proposition that the profit rate is inversely related to labour's proportionate share and tends downwards during the course of growth despite the fall in the corn wage, can be restated. For the labour embodied in the lower corn wage (and thus in the general wage basket) increases, and this increase is reflected in a higher money wage rate: 
As population increases . . necessaries will be constantly rising in price, because more labour will be necessary to produce them. If then the money wages of labour should fall, whilst every commodity on which the wages of labour were expended rose, the labourer would be doubly affected, and would be soon totally deprived of subsistence. Instead, therefore, of the money wages of labour falling, they would rise; but they would not rise sufficiently to enable the labourer to purchase as many comforts and necessaries as he did before the rise in the price of those commodities.

But since the money wage tends to rise while the money value of marginal output is constant, the residual (profits) is necessarily squeezed. In terms of labour, the money wage reflects both labour embodied in the wage basket and proportionate wages.

The status of the labour theory in the above account is to provide the simplest possible exposition of the inverse wage-profit relation in value rather than physical or corn terms. But Ricardo did not believe that everything hinged on the satisfaction of the strong conditions entailed. There were severe measurement problems, not least that commodities are not all produced with the same factor intensities. Yet he stood by the inverse wage-profit relation suggesting a measure entailing average factor proportions but also quite generally, assuming actual as distinct from 'ideal' money - basing himself on the assurance of a constant general level of prices in the face of changing money wages - and even assuming fiat rather than commodity money (104-5, 126-7).

\section{The labour theory, cost-price and demand-and-supply analysis}

The third element involves the theory of commodity pricing, and has been silently alluded to already in discussing labour values. For the labour theory is nothing more than a theory of long-run cost price assuming uniform factor intensities, as I shall explain.

'Cost of production' or 'natural price' includes profits as well as wages each at its average or ordinary rate. Ricardo's labour theory accounted for relative price movements and did not imply that full costs excluded the return to capital: 'I have not said' - as Malthus understood him - that

because one commodity has so much labour bestowed upon it as will cost $1000 l$. and another so much as will cost 2000l. that therefore one would be of the value of $1000 \mathrm{l}$. and the other of the value of $2000 \mathrm{l}$. . I affirm only, that their relative values will be governed by the relative quantities of labour bestowed on their production.

(46-7; see also 405-6) 
As expressed in the Essay on Profits of 1815: 'the price of all commodities is ultimately regulated by, and is always tending to, the cost of their production, including the general profits of stock' (Ricardo 1951-73, 4: 20n.).

The principle of profit-rate equalization itself turns on standard (Smithian) demand-supply analysis:

It is then the desire, which every capitalist has, of diverting his funds from a less to a more profitable employment, that prevents the market price of commodities from continuing for any length of time either much above, or much below their natural price. It is this competition which so adjusts the exchangeable value of commodities, that after paying the wages for the labour necessary to their production, and all other expenses required to put the capital employed in its original state of efficiency, the remaining value or overplus will in each trade be in proportion to the value of the capital employed.

(Ricardo 1951-73, 1:91)

And since it is 'through the inequality of profits, that capital is moved from one employment to another' (119), disturbances impinging equally on all commodities, including an economy-wide change in labour productivity, have no differential effects on profitability at the initial long-run cost prices and therefore generate no changes in supply, leaving those prices unchanged. By contrast, a disturbance limited to a single industry, such as a change in input coefficients or a specific tax or subsidy, raises or lowers the industry return on capital and so will generate an increase or decrease in industry output and consequent alteration in price, to re-establish the original return in that industry. Applications of the distinction in question extend to the fundamental nature of trade. For any 'cause' that raises the cost price of one or even a few manufactured commodities

would prevent or check their exportation; but if the same cause operated generally on all, the effect would be merely nominal, and would neither interfere with their relative [cost] value, nor in any degree diminish the stimulus to a trade of barter, which all commerce, both foreign and domestic, really is.

We return to the labour theory. Under conditions of uniform factor proportions, a state of general equilibrium such that prices reflect costs throughout the system will be one satisfying both profit-rate uniformity and proportionality of price to labour inputs; more accurately, uniformity of profit rates requires that proportionality, the equilibrium condition being that the capitalist 'should derive ... the usual and general rate of profits on stock, and that could only happen when his commodity sold for a price proportioned to the quantity of labour bestowed on its production' (73). It is the 
possibility of capital (and labour) movement between uses, or commoditysupply adjustment, which assures the tendency to cost price and proportionality to labour input. In circumstances of differential factor ratios the same assumption of factor mobility dictates a divergence of cost prices from labour inputs. But the entire notion of cost price presumes factors that do have alternative uses; and whether or not costs are proportional to labour inputs, only those returns that reflect alternative opportunities are allowed for in costs, for which reason Ricardo excluded land rent.

The principle that cost prices reflect the absence of preferable alternative opportunities also provides the rationale for the inverse wage-profit relation. In the event of uniform factor proportions the labour theory applies, and there will occur no price changes when the general wage is raised; and since prices do not vary at all, general profits must be affected inversely. In the case of differential factor proportions between industries the impact of a general wage increase is more complex. At the initial prices the profit rate must decline across the board; but the decline will be sharper in 'labourintensive' than in 'capital-intensive' industries and accordingly reallocation of resources between sectors will be set in motion in response to the disturbed structure of returns on capital. In the new equilibrium the prices of commodities produced by labour-intensive processes will have risen relative to those produced by capital-intensive processes - outputs contracting in the first category and expanding in the second - and the profit rate will again be equalized everywhere but at a lower level than in the initial equilibrium. The allocative rationale for the inverse wage-profit relation in the complex case is implied by Ricardian logic and explicitly formulated by J. R. McCulloch who also points to the constancy of the supply and therefore the prices of commodities produced with medium coefficients (McCulloch 1825a: 303-4; 1864: 286-7). Interindustry substitution thus provides the key to the Ricardian analysis of the allocative effects of a wage change, and in the general case of non-uniform factor ratios such changes in distribution affect relative cost prices by generating appropriate output variations.

Two details touching on allocation theory may be added here to our earlier discussion of the growth process. First, the downward pressure on the wage to which we there referred is motored proximately by the decelerating capital accumulation - and thus growth rate of aggregate labour demand - imposed by the land-scarcity constraint. Now labour-demand conditions turn, more specifically, not on total capital but on the so-called 'circulating' as distinct from 'fixed' component of capital. Thus they vary not only with technological change that plays on capital composition but also by changes in the pattern of demand for final goods, in the event of non-uniform factor intensities in the affected industries. Final expenditure patterns matter for distribution: 'the labouring class have no small interest in the manner in which the net income of the country is expended' (Ricardo 1951-73, 1: 392). Conversely, changes in distribution play upon final demand patterns: 'If in the division of the gross produce, the labourers commanded a great proportion, the demand would be for one set of 
commodities - if the masters had more than a usual share, the demand would be for another set' (Ricardo 1951-73, 8: 272-3). There is thus a mutual relationship between distribution and pricing which complicates the simple growth pattern. And secondly, the margin of cultivation itself is an endogenous variable, with the long-run cost price of corn subject to the mutual conditioning of demand as well as supply (see citation given below, p. 7).

Where strict constraints on factor supply are assumed Ricardo obtains the result that the return to that factor emerges as a demand-determined surplus. One instance is zero supply elasticity in the case of land where more intensive utilization is ruled out by assumption; here rent emerges as a demanddetermined surplus on every unit of corn produced including the last. In this case, the incidence of a tax on corn is borne entirely by producers:

The corn and raw produce of a country may, indeed, for a time sell at a monopoly price; but they can do so permanently only when no more capital can be profitably employed on the lands and when, therefore, their produce cannot be increased. . . . At such a time too, any tax which may be imposed on the farmer, will fall on rent, and not on the consumer. He cannot raise the price of his corn, because, by the supposition, it is already at the highest price at which the purchasers will or can buy it. He will not be satisfied with a lower rate of profits, than that obtained by other capitalists, and, therefore, his only alternative will be to obtain a reduction of rent, or to quit his employment.

(Ricardo 1951-73, 1: 250-1)

As for Ricardo's more general appreciation of the role of demand in a market system a striking instance is provided by his objection to the Malthusian sequence of increased food supply prior to population growth. As he explained to Hutches Trower, in a letter of 26 September 1820, only in a control economy can demand considerations be dispensed with; in a market system expansion of food supply, like that of any other commodity, turns on 'actual or expected demand':

It is undoubtedly true that if production were wholly under the control of one individual, whose object it was to increase population, he could not better effect his object than by growing more corn in the country than the existing community could consume - it would in that case be at a low price, and the greatest stimulus would be given to population. [But] ... what we want to know is, whether, in the present distribution of property, and under the influence of the motives which invite to production, corn is produced for any other reason than that iron, silk, wine, etc. are produced - whether they are not all produced on account of an actual or expected demand for them.

(Ricardo 1951-73, 8: 255-6) 
In this letter too the role of demand is explained in the analysis of the impact of net capital accumulation assuming short-run and long-run laboursupply conditions. It is only to the extent that such accumulation generates increased demand for food by labour that corn output expands (258). All this is laid out in the Principles in a passage that also elucidates the endogenous demand-determined margin of cultivation:

When a high price of corn is the effect of an increasing demand, it is always preceded by an increase of wages, for demand cannot increase, without an increase of means in the people to pay for that which they desire. ... Corn rises then because the demand for it increases, because there are those in the society who have improved means of paying for it; and the profits of the farmer will be raised above the general level of profits, till the requisite quantity of capital has been employed on its production. Whether, after this has taken place, corn shall again fall to its former price, or shall continue permanently higher, will depend on the quality of the land from which the increased quantity of corn has been supplied.

(Ricardo 1951-73, 1: 162-3)

There is a caution to introduce at this point, relating to the proposition in the terminology adopted by J. S. Mill - that 'demand for commodities is not demand for labour' (Mill 1963-91 [1848], 2: 78). This is not a denial of micro-economic 'derived demand', but alludes to the process - as outlined in the foregoing extracts from Ricardo - of saving and accumulation as source of demand for labour in the aggregate (see Hayek 1941: 433-9; Johnson 1949: 531-6). Secondly, the short-run labour-supply constraint is not to be taken lightly. Unlike regular commodities, you cannot increase their number in one or two years when there is an increase of capital, nor can you rapidly diminish their number when capital is in a retrograde state' (Ricardo 1951-73, 1: 165). 'There must be a considerable interval' before full adjustment to an increase or decrease in capital accumulation.

\section{The 'Law of Markets'}

One version of the 'Law of Markets' has it that the money value of commodities supplied is identically equal to the money value of commodities demanded; another, that the two are equal only in conditions of equilibrium. The former may be interpreted to imply that money per se has no utility to recipients who, having no reason to hold it in the form of cash balances, attempt to disburse it immediately for goods. Under these conditions prices will be driven up to infinity given any positive money supply, which in fact implies the absence of money stocks, that is, a barter system wherein the price level has no relevance. This version of the Law of Markets is inconsistent with the 'quantity theory', which implies a determinate level of prices for every given money supply. 


\section{Introduction}

A weaker version of the Law of Markets avoids this inconsistency. In the familiar terms of Lange (1942),

$$
\sum_{i=1}^{n-1} p_{i} D_{i}=\sum_{i=1}^{n-1} p_{i} S_{i}
$$

where $p_{i}$ denotes the going price of commodity $i$, and $D_{i}$ and $S_{i}$ the quantities demanded and supplied at that price, such that with $(n-1)$ commodities exclusive of money, money constituting the $n$th commodity, the aggregate money value of commodities demanded and supplied will be balanced in equilibrium. Here temporary periods of excess commodity supply are allowed to which correspond excess demand for money to hold. On this second view, a doubling of both the money supply and the price level will leave relative prices unchanged. Relative prices thus appear to be determined solely in the 'real' sector of the economy while the level of prices depends on the supply of money. But in fact substitution of money for commodities and substitution between commodities occur in any transition between equilibrium states as just described; relative prices - and the interest rate - may well be affected (temporarily) by changes originating in the money market.

That Ricardo subscribed to the equality version is clear from his allowances for depression reflecting excess demand for money and excess supply of commodities, generated by sudden contraction of the money supply:

a reduction in the amount of the circulating medium should speedily operate on prices, but the resistance which is offered - the unwillingness that every man feels to sell his goods at a reduced price, induces him to borrow at a high interest and to have recourse to other shifts to postpone the necessity of selling. The effect is however certain at last, but the duration of the resistance depends on the degree of information, or the strength of the prejudices of those who offer it, and therefore it cannot be the subject of any thing like accurate calculation.

(Ricardo 1951-73, 7: 67) ${ }^{1}$

When the market prices of goods fall ... from a rise in the value of money, a manufacturer naturally accumulates an unusual quantity of finished goods, being unwilling to sell them at very depressed prices. To meet his ordinary payments, for which he used to depend on the sale of his goods, he now endeavours to borrow on credit, and is often obliged to give an increased rate of interest. This, however, is but of temporary duration; for either the manufacturer's expectations were well grounded, and the market price of his commodities rises, or he discovers that there is a permanently diminished demand, and he no longer resists the course of affairs: prices fall, and money and interest regain their real value. 
Ricardo clearly allows for temporary deviations between the money values of commodities supplied and demanded, or temporary excess demand for money. And it is because of concern with the level of activity in such circumstances that he devised the ingot plan, recommended a degree of credit flexibility in the banking system, accepted temporary devaluation, and even justified permanent devaluation under some circumstances.

While temporary deviations between aggregate demand and supply are recognized, there is nothing in the course of secular expansion to bring them about. The only reason for profit-rate decline in the course of growth is either the rising cost of wage goods or (possibly) constraints on labour supply. In the absence of such land or labour limitations accumulation can proceed without check putting paid to the sort of concerns expressed by Malthus or Sismondi. It is to this secular sphere that the Law of Markets pertained.

\section{On surplus}

As we have indicated, Ricardo elaborated the market determination of wages and prices and their interdependence. Though a given wage permits (ceteris paribus) a 'forecast' of the average profit rate, the wage is not in fact a datum, but is determined in the labour market and played upon both by the growth rate of capital (partly motivated by the return on capital) and the pattern of final demand, the latter itself partly governed by the (variable) income distribution. The breakdown between wages and profits is, for Ricardo, a variable determined within the market economy.

At the same time, Ricardo was certainly deeply concerned with matters relating to 'surplus'. He focused particularly on the source of investible funds (and of tax capacity) in which context there is much said of the alternative savings patterns of the various classes. And that increased efficiency - via trade or technical change - expands the surplus available for accumulation and taxation, though not necessarily the profit rate, is a major theme (Ricardo 1951-73, 1: 8, 133). Even the 'source' of profits in surplus labour time - which was to be formally spelled out by J. S. Mill (1963-91, 2: 411) - is implicit in the Ricardian inverse profit-wage relation. But to isolate the source of profits (interest) in surplus labour time does not rule out the notion of interest as a necessary reward for saving such that ' $[\mathrm{t}$ ] $\mathrm{he}$ motive for accumulation will diminish with every diminution of profits' (above, p. 1). Productivity conditions assure an excess over the output consumed by labour and is the basis for investment demand, while abstention from present consumption relates to capital-supply conditions. But if, as for Ricardo, the wage rate is a variable partly governed by capital-supply conditions, it follows that the 'necessary' part of the work day is as much a consequence as a determinant of the 'surplus' part. As Ricardo put the matter in the taxation context, there is a 'natural equilibrium between profits and wages', profit taxation acting to reduce the rate of accumulation so that the burden is shared between capital and labour (Ricardo 1951-73, 1: 226). 


\section{Adherents to 'classicism'}

Paul Samuelson (1978) finds in the Wealth of Nations a fully fledged land-based growth model. There indeed are elements of the model in Smith's text: appreciation of increasing-cost industries and of differential rent - though not in the analysis of corn pricing; the impact of land-scarcity conditions in depressing the general profit rate to a minimum - though interspersed with the notion of increasing 'competition of capitals' during the course of growth reflecting upward pressure on wages and downward pressure on final prices; in the context of economic development the prediction of a fall in the agricultural relative to the manufacturing profit rate as population growth generates increasing land scarcity and a consequent rise in rents and fall in wages; and a downward wage path implicit in the notion of a minimum wage at which population growth ceases, that is, in the recognition of a stationary-state wage. But the growth analysis is incomplete: while high wages and high profits are said to characterize early states not yet subject to land-scarcity constraints - such as new colonies - the rationale for the downward course of wages in a deceleration of accumulation imposed by increasing land scarcity is not spelled out. And Smith did not ask why, given scope for a decline in the real wage, there should be a necessary reduction in the profit rate, and thus did not reach the Ricardian position that the inverse wage-profit relation holds good in terms of proportionate shares, the falling secular wage entailing a necessary rise in labour's share in the declining 'marginal' product. (There is also an uncoordinated 'increasing-returns' component of Smith's economics which treats innovation as an endogenous variable.) The growth model, it may be allowed, was 'in the air' when Ricardo came on the scene in so far as several of its elements are to be found in the Wealth of Nations, but there is no fully fledged Smithian version. Important too is the fact that the main contributors to the corn-law pamphlet literature of February 1815 (Ricardo, Malthus, Sir Edward West, Robert Torrens) did not find in Smith the principle of diminishing returns.

As mentioned, Smith lacked the inverse wage-profit relation as a proposition relating to proportions. This is a fortiori the case in a monetary system since he maintained that any increase in the money wage can be passed on either to landlords or to consumers, in sharp contrast to the Ricardian position. Ricardo himself thought of his own analysis in these respects as novel contributions to the science.

I turn to the Law of Markets. The Smithian doctrine of savings, which eulogized capital accumulation - Smith in one usage refers to labour in the capital-goods sector as 'productive' labour - and maintained that the process of savings entails no leakages from the income stream, implies that no attempt is made to add to money balances from sales proceeds. Yet Smith did not explicitly formulate the proposition that (given tolerable security) there can be no general excess supply of commodities - the counterpart of the absence of net hoarding. And, most significant, his increasing 'competition-of-capitals' concept implies a constraint on secular expansion wholly independent of 
increasing land scarcity and reflecting a failure of markets to expand in proportion with aggregate output.

What then did Ricardo take from the Wealth of Nations? Primarily the general principle of cost price, elaborated in Smith's chapter 'Of the Natural and Market Price of Commodities', or the analysis of pricing in the context of general equilibrium in the sense outlined earlier, whereby in equilibrium there are no further gains to be made by reallocation of resources between sectors; and also the relation between market-clearing short-run and long-run prices which assures a tendency to equilibrium. Full Smithian equilibrium (the achievement of 'natural prices') implies uniform returns to each factor at their 'natural rates', that is their average rates, which outcome is assured by factor mobility between industries (Smith 1937 [1776]: 56-8). But there is this difference, that Smith usually included rent within cost price on grounds of multi-use land. And he undertook much of his allocative analysis in a developmental context involving an open economy subject to variations in factor proportions over time.

On the other hand, there is Ricardo's correction of Smith's conclusion that a general wage increase will raise prices across the board. Standard partial-equilibrium analysis - the demand-supply analysis applied to a single industry - is inappropriate for the analysis of this disturbance. As we have seen, in the case of uniform factor ratios there will be no effect; in that of non-uniform ratios, while some prices will indeed be higher in the new equilibrium, others will be lower, supply conditions having deteriorated in the former case but actually improved in the latter, 'improved' in a relative sense as is meaningful only within a general-equilibrium framework.

In one other respect in a related context Ricardo corrected Smith. For Smith had asserted of agriculture that it was the most productive sector, having in mind a return to land (rent) in addition to the returns to capital (profit or, rather, interest) and labour (wages) which characterize the manufacturing sector, an easy error to make reflecting a degree of agricultural bias perhaps absorbed from the Physiocrats. Ricardo pointed out that the payment of rent to the third factor reflected not only productivity but scarcity conditions, so that, first, were agricultural land supplies to increase, rents would fall to the benefit of workers and capitalists; and secondly, were natural forces to become scarce in manufacturing a rent would have to be paid their owners at the expense of wage and profit earners (Ricardo 1951-73, 1: 76). The deemed advantage of agriculture was an optical illusion.

I turn next to Malthus. Malthus laboured under the misconception that Ricardo failed to apply demand-supply analysis to long-run cost pricing, working with what has recently been termed a 'one-legged' theory allowing solely for supply conditions. Certainly Malthus strived to show that 'the great principle of demand and supply is called into action to determine what Adam Smith calls natural prices, as well as market prices', that 'cost of production itself only influences the prices of these commodities as the payment of this cost is the necessary condition of their continued 
supply' (Malthus 1820: 74-5). But this was precisely Ricardo's position too. Nothing Ricardo could say caused him to abandon his misinterpretation, including Ricardo's repeated insistence, first, that growth of population, and therefore of demand, must precede extensions of agriculture (the matter of the endogenous margin); and secondly, more generally, that he was arguing for the primacy of supply, not for supply as the sole consideration in pricing. There is little then to justify designating Malthus as a 'subjective value' theorist in any sense that would not also apply to Ricardo. Indeed, in some important respects Ricardo's allocative orientation is more striking than Malthus's. For, much to Ricardo's distress (Ricardo 1951-73, 1: 405-6), Malthus excluded long-run corn pricing from treatment in terms of demand and supply on the grounds that the demand and supply schedules are interdependent in that special case - having in mind the corn-population relation - whereas regular pricing analysis requires their independence (Malthus 1986 [1815], 7: 121). On this view supply precedes population growth; Malthus in effect applies Say's Law to food in a strong form - supply creates its own demand.

Malthus laid claim to a typical and non-Ricardian concern with the 'short run'; but the corn-pricing analysis - which reflects in part his 'Physiocratic' heritage - belies the claim. Also to be noted is Malthus's acceptance of the Smithian notion of the superior productivity of agriculture - notwithstanding recognition elsewhere of the diminishing-returns property - against which Ricardo remonstrated in his Essay on Profits (Ricardo 1951-73, 4: 37-8).

As for Malthus on growth theory, specifically the 'shared-incidence' principle, splendid formulations will be found in the fifth edition of the Essay on Population (Malthus 1817, 2: 433-5) and in the Principles of Political Economy (Malthus 1820: 297-9), with explanations of the constraint on the fall in the real (corn) wage relative to the marginal product such that labour's proportionate share rises, thus depressing the profit rate. The precise incidence of diminishing returns between labour and capital is said to be market determined - an allusion to competition in the labour market - in criticism of Ricardo, though that was precisely Ricardo's position. At least Malthus paid warm tribute to Ricardo for the general inverse wage-profit relation while at the same time he insisted on his own measure of value to obtain the same result.

There is then little doubt of a profound contribution by Malthus as regards the central traditions of the theory of value and distribution, including here the theory of population in a land-scarcity context, once we silence the noise emanating from his misunderstandings of Ricardo and the exaggerated representation of his own procedures as substantively and methodologically distinct. At the same time, the physiocratic-based or Smithian agriculturalsurplus construct complicates the picture. So too does Malthus's position regarding aggregate equilibrium. This problem does not pertain to his various allowances for unemployment and excess capacity, since Ricardo did not rule out short-term excess supply. It is in the secular realm that any notion of a 
common 'classical system' seems to break down considering Malthus's concern with the possibility of non-sustainable growth unrelated to land scarcity. ${ }^{2}$

\section{A widening of scope}

Up until the present day we find reference to a Jevonian revolutionary break away from 'classicism' in the early 1870s, on the theory of value, though with allowance for Malthus as embryonic precursor. Thus Schumpeter denied that cost prices were understood by Ricardo as reflecting equilibrium between demand and supply, or market-clearing prices; it was Malthus who 'nicely indicat[ed] the locus of cost of production, which "only determines the prices of commodities, as the payment of it is the necessary condition of their supply" - pointing far ahead toward Jevonian teaching' (Schumpeter 1954: 602). Jevons himself wrote warmly of Malthus:

There were Economists such as Malthus and Senior, who had a far better comprehension of the true doctrines (though not free from the Ricardian errors), but they were driven out of the field by the unity and influence of the Ricardo-Mill school.

(Jevons 1879: li-lii)

This same misapprehension regarding Ricardo, that he rejected the demandsupply explanation of long-run price and excluded a subjectivist dimension, was also expressed by Malthus himself (as noted above) and numerous contemporaries; in early neo-classical writers in addition to Jevons, including Walras and Wicksell; in the modern literature (Arrow, Hicks, Samuelson); and - most conspicuously perhaps - in the Sraffian or 'Cambridge' literature, though for Sraffian writers the alleged rejection is a matter for applause not for blame. In reality, Malthus and Ricardo were at one - following Adam Smith - in maintaining a 'two-legged' theory of long-run price. And to this extent 'classicism' never died out, but was absorbed into modern doctrine via Alfred Marshall's great synthesis.

The same complex picture emerges in the context of classical growth theory. First, while nearly all the expert economists in the period 1815-75 (in addition to Ricardo, Malthus and J. S. Mill I would list West, Torrens, James Mill, Bailey, McCulloch, Chalmers, Senior and Cairnes) adhered to the 'shared-incidence' principle, they were, with some important exceptions (McCulloch, Senior and Cairnes), often unaware of Ricardo's own position, attributing to him some version or other of constant-wage growth. (See for details Hollander 1998a.) In brief, Ricardo did not fulfil the role of leader equivalent to Quesnay in eighteenth-century France; and the classical doctrine was upheld by, so to speak, an invisible school whose members in many cases made a living by attacking Ricardo. However, warm tribute was widely paid to Ricardo for his inverse wage-profit relation as a general proposition regarding proportions. There was, that is to say, almost universal 


\section{Introduction}

recognition of Ricardo's inverse wage-profit relation given productivity (the wage-profit frontier), but wide neglect of his elucidations of inward displacements of the frontier with increasing land scarcity such as assure a contemporaneous decline in the returns to both variable factors.

Secondly, I believe Samuelson is quite correct when he argues that the canonical model was subscribed to by the late nineteenth-century 'neoclassicals' and by moderns - that 'all tell essentially the same classical story'. For Samuelson justly denies that classical political economy offers an 'alternative paradigm', in Thomas Kuhn's sense, 'to modern mainstream economics' (Samuelson 1978: 1430n., 1415).

\section{Policy and application}

The classical theory of economic policy entails a general presumption in favour of the competitive market in a private-property environment as means to maximize real (per capita) national income - and thus the wherewithal for consumption and accumulation (see Eltis 2001). I briefly illustrate from some price-theoretic applications made by Ricardo.

There is first to note Ricardo's 'subjectivist' welfare orientation in his discussion of the benefits flowing from international trade, namely the increase in 'the mass of commodities, and therefore the sum of enjoyments':

It is quite as important to the happiness of mankind, that our enjoyments should be increased by the better distribution of labour, by each country producing those commodities for which by its situation, its climate, and its other natural or artificial advantages, it is adapted, and by their exchanging them for the commodities of other countries, as that they should be augmented by a rise in the rate of profit.

(Ricardo 1951-73, 1: 132)

International specialization - by the 'pursuit of individual advantage' 'distributes labour most effectively and most economically: while, by increasing the general mass of productions, it diffuses general benefit' (133-4).

Given this orientation, it is scarcely surprising to find Ricardo insisting that corn-law abolition would entail much more than a mere transfer of wealth away from landlords; there would be assured a net social gain deriving from improved efficiency of resource allocation (314). The same logic underlies Ricardo's proposal in 1822 for a countervailing duty on corn envisaged as an instance of legitimate intervention, the duty compensating for the differential burden on domestic agriculture imposed by the system of tithes; again notice the consumer-directed orientation:

[W] ith a view to the real interest of the consumer, in which the interests of the whole community are, and ever must be, included, whenever any peculiar tax falls on the produce of any one commodity, from the 
effects of which all other producers are exempted, a countervailing duty to that amount, but no more, should on every just principle be imposed on the importation of such commodity; and further, that a drawback should be allowed, to the same amount also on the exportation of the like commodity.

(Ricardo 1951-73, 4: 243)

By this means, runs the argument, '[t] the course of trade would be left precisely on the same footing as if we were wholly an untaxed country, and every person was at liberty to employ his capital and skill in the way he should think most beneficial to himself' (244).

Policy considerations relating to the theory of growth are our next concern. Diminishing agricultural returns were the source of an increase in proportionate wages (wages as a share of the marginal product), and thus a fall in the profit rate, notwithstanding a secular decline in the real wage. But Ricardo and Malthus made no literal prediction of falling real wages. To the contrary: the raison d'être of their analysis was to encourage the creation and development of institutional arrangements likely to assure against deterioration of standards, by altering labour-supply conditions in favour of prudential population control. Such efforts would, they fully realized, bring about a sharper rise in labour's proportionate share in the marginal product and thus a sharper fall in the profit rate than in the absence of prudential population control and hasten the arrival of the stationary state; but it would be a tolerably comfortable state for the masses. (In any event, even the sharper fall in the profit rate that would result from successful population control might be avoided by the fortuitous intervention of technical change.) The classics, in brief, utilized their engine of analysis to indicate what might happen under alternative assumptions. Their models were classificatory devices to aid in framing social policy, not predictive devices.

\section{The Ricardo-Say relation: a review of the literature}

For a recent subtle statement of a perceived paradigmatic contrast between a Sayian and a Ricardian orientation I cite Gehrke and Kurz:

In one place the author of the Treatise wrote about his analysis of the sources of production and of revenue that it leads us 'into the labyrinth of the science of political economy'.... If one had to describe Ricardo's analysis in terms of Say's metaphor, one might say that it was designed to show the reader a way out of that labyrinth.

(Gehrke and Kurz 2001: 477-8; also 2003: 257)

From a different historiographical standpoint but to much the same effect, O'Brien asserts: 'That Say was an economist in a distinct French tradition, with the emphasis on utility, and not a mere popularizer of Adam Smith is 
not, I think, any longer in dispute' (O’Brien 2001: 382). Even more strongly, Say's French tradition was 'wholly different' from the British costof-production approach,

one consistent with the post-1870 approach to value theory: of the interaction of subjective valuation (underlying demand) and limitations in supply. Say argued that both goods and productive services derived their value from the utility of the final product. Price was determined by the intersection of a negatively sloped demand curve (described verbally) and a rising supply schedule.

(O’Brien 2003: 116)

In a summary of position regarding the Traité, Schoorl makes no mention whatsoever of costs, opining that Say's 'greatest merit in the field of value probably lies in the subjective elements on which he contemplated' (Schoorl 1980: 150).

This sort of contrast constitutes a conspicuous feature of Schumpeter's History of Economic Analysis:

it was the 'subjective' or 'utility' theory of price that had the wind until the influence of the Wealth of Nations - and especially of Ricardo's Principles - asserted itself. Even after 1776, that theory prevailed on the Continent, and there is an unbroken line of development between Galiani and J. B. Say.

(Schumpeter 1954: 302; see also 234)

More specifically, Schumpeter maintained that, for Say, exchange value depends on utility as 'source' or 'cause' of value - rather than merely being 'a condition of exchange value' (as it was with Ricardo), but that he could not carry the issue further, 'failing (like Condillac) to add scarcity', and 'ineptly' explaining that the reason why useful things like air and water normally have zero exchange value was because their value was infinitely great so 'that nobody could pay for them and hence they go for nothing' (599-600). Schumpeter, however, added

that he did not stop at this ineptitude. He did rise to the imperfect (yet so significant) statement that price is the measure of the value of things and value is the measure of their utility, a statement that heralds Walras': 'Les valeurs d'échange sont proportionnelles aux raretés [marginal utility]'.

And he here allowed also that Say ' $[\mathrm{m}]$ ostly ... merely used a rather primitive supply-and-demand analysis'.

What though of costs of production and its relation with supply and demand? Schumpeter's response implies a failure on Say's part to deal adequately with the technicalities of the relation: 
Say's contribution is enshrined in the proposition that cost of production is nothing else than the value of the productive services that are consumed in production; and that the value of the productive services is nothing else than the value of the commodity which is the result another of those sayings of his that indicate possible insights without making them explicit enough for contemporaries and later critics to understand.

Malthus, by contrast, 'though he probed less deeply, explained things much better so far as he saw them ... nicely indicat[ing] the locus of cost of production which "only determines the prices of commodities, as the payment of it is the necessary condition of their supply", thereby "point[ing] far ahead toward Jevonian teaching'. Notwithstanding, Schumpeter inserted a note to the effect that 'Say and Malthus were so far as value is concerned, as much on one side as they were on opposite sides in the question of saving and general gluts', though 'there was no perfect agreement between the two in the first case, and no perfect agreement between Say and Ricardo on the second' (599n.).

Schumpeter seems to have neglected the fact that Malthus's perception of things is simply that of Adam Smith in his chapter 'Of the Natural and Market Price of Commodities' - a chapter greatly admired by Schumpeter himself as a fine statement of embryonic general equilibrium or allocation economics (189). As for Ricardo, he is not even listed among those concerned with the question 'How cost of production fits with supply and demand', Schumpeter referring only to 'Lauderdale, Say, Malthus, and others' (602). This omission is deliberate, reflecting Schumpeter's attribution to Ricardo of a 'one-legged' cost theory of long-run price (220).

Schumpeter's reading of Ricardo is not my immediate concern. Rather it is the implication - spelled out in O'Brien's version - that Say neglected the cost dimension, working at best in 'primitive supply and demand' terms and (unlike Malthus) failing to 'indicate the locus of cost of production'. This is perhaps not so much an attribution of contrasting paradigms - cost of production analysis on the one hand and demand-supply analysis on the other - as an alleged failure on Say's part to link the two analyses appropriately. Schumpeter apparently focused entirely in his account of Say on instances of some form or other of factor specificity which precludes the tendency of market to cost price and uniformity of return. But a notion of paradigmatic contrast between the cost and demand-supply approach is certainly to be found in the literature, as in Joan Robinson's assertion that in a market economy either there may be a tendency towards uniformity of wages and the rate of profit in different lines of production, or prices may be governed by supply and demand, but not both', for 'where supply and demand rule, there is no room for uniform levels of wages and the rate of profit' (Robinson 1961: 57). This assertion is misleading. Certainly given each and every type of capital good, labour and land, returns to each emerge 
as a 'rent' determined by demand conditions; but assume factor mobility, and 'rents' - positive and negative - are eliminated as returns tend to uniformity, and this by way of supply adjustment.

Ricardo, like Malthus following Adam Smith, elaborated with care the supply adjustments which assure the tendency of market to cost price (above, p. 4). But Say we shall show was in this same tradition. There is no gainsaying his concern also with cases of 'permanent' constraint on supply due to some form or other of factor specificity such as a peculiar 'talent' in the case of labour. In such cases, an increase in the demand for a product and in its market price generates a 'permanent' rise in some one or more of the returns; and these cases - 'pseudo-cost' we shall call them - were sometimes represented by Say as formally satisfying the cost determination of price since the sum of the service prices composes costs. (Even market prices temporarily exceeding natural price imply that one or more of the factors will earn positive rents, so that it might be said that prices cover costs even in the short run.) This, however, is not a paradigmatic contrast, but a matter of alternative assumption. Thus where strict constraints on factor supply are assumed by Ricardo, he obtains the same result - the return to a factor as a demanddetermined surplus (above, p. 6); while conversely, Say also elaborated upon factor mobility, uniformity of return, and 'genuine' cost price.

We come now to the more specific claim that after Ricardo's death in 1823 Say 'resisted the Ricardian School more and more resolutely', the fifth edition (1826) of the Traité and the Cours Complet (1828-9) 'revealing this change of tone', by 'includ[ing] a much more marked criticism of Ricardo, and especially McCulloch' (Steiner 1998a: 206, n. 26). Steiner does not positively deny that, for Say, 'an equalisation of profit rates can take place', or that - as '[słome of his remarks lead us to believe' - 'the owners of resources, particularly of capital in monetary form, invest their capital on the basis of the rate of return expected for a given risk' (209-10). But these are rather hesitant allowances. Essentially, from 1823 on, 'Say radicalise sa réflexion en accentuant le côté demande de son analyse et en s'efforçant d'expliciter aussi clairement que possible les relations entre besoins, utilité, demande, revenus et prix' (Steiner 2003: 342-3). And Steiner proposes a numerical measure of the alleged change of tone in the 1826 Traité:

L'ouvrage offre maintenant une version de plus en plus négative de l'oeuvre de Ricardo: le ratio références négatives/positives était nul en 1817; il était égal à 1,15 en 1819; il est maintenant de 2,14, niveau que maintiendra le Cours complet avec un ratio égal à 2,22 (Steiner 1999, table IX).

(Steiner 2003: 355)

A similar position is maintained by Potier:

Nous tenterons de montrer que Jean-Baptiste Say, engagé dans une controverse avec David Ricardo entre 1815 et 1822, dans sa réflexion sur les 
fondements de la valeur des marchandises, va attacher une importance croissante à l'utilité et s'efforce de réduire celle des frais de production.

(Potier 2003: 283)

Again:

Jean-Baptiste Say, au fil des éditions successives du Traité d'économie politique entre 1803 et 1826, sous l'effet de la polémique avec Ricardo, privilégie de plus en plus l'utilité et tente de réduire l'importance des frais de production en tant que fondement de la valeur des merchandises.

Soliani maintains to similar effect that from 1814 onwards Say distanced himself from the 'surplus' tradition enunciated in the Traité of 1803, in favour of the Italo-French ('supply-demand') tradition represented by Galiani and Condillac (Soliani 2003). Forget claims that Say abandoned the cost explanation of value in the fifth edition of the Traité (1826) and the Cours Complet (1828-9), when he argued that the prices of productive services depend upon the prices generated by the demand and supply for final commodities. The case of rent illustrates this transition' (Forget 1999: 156). Similarly, she affirms that

over time, Say's position does change dramatically in such a way that, by the fifth edition of the Traité, he explicitly rejects any suggestion that land rents help to determine prices of final commodities in a Smithian sense, while adamantly maintaining his independence from the Ricardian suggestion that land rent depends upon the extension of cultivation to marginal lands.

In more general terms, Gehrke and Kurz contend that

already at the time of his notes [1819] to the French edition of [Ricardo's Principles 1819] Say, who originally had expressed his concern with adapting his doctrine in order to gain Ricardo's approval of it, changed his attitude. After Ricardo's death he openly attacked Ricardo and diminished his achievements.

(Gehrke and Kurz 2001: 476; also 2003: 256)

It will be our argument that while Say sought to convey an impression of growing divergence, he approached closer and closer to the canonical position not only regarding value theory but also with respect to growth theory and the nature of 'riches'. As for value theory, we note that Richard Arena also places considerable weight on Say's allowance for 'difficulty of production', seeing in it a 'rapprochement' with the Ricardians which is 'loin d'être 
superficiel' (Arena 2003: 311); and so too does Diemer when he writes that Say attempted a reconciliation between 'les partisans de la théorie d'utilité et ceux des coûts de production' (Diemer 2003: 372). The historiographical implication of our conclusion is apparent. Both Say and Ricardo were precursors of Marshall in attending to demand-and-supply considerations in the analysis of price, in both the short run and the long run with emphasis on the priority of supply (cost) conditions in the latter case. It may be remarked incidentally that Piero Sraffa, in discussing the nature of 'costs' in his famous Cambridge lectures of the late 1920s, also represented Say's perspective as running along embryonic 'Marshallian' lines, in contrast to the idea of cost maintained by the Physiocrats, Petty and Cantillon (see Hollander 2000). Needless to say, Sraffa did not place Ricardo in that line.

We turn now to another feature of the secondary literature - the view, as expressed for example by Steiner - that Say "produces nothing comparable to the "grandiose dynamic" that Ricardo constructs on the basis of his theory of distribution' (Steiner 1998a: 209); or in Forget's version, that Say

never develops anything like a Ricardian distributional scheme, in which increasing population forces the cultivation of marginal lands that yield no rents, driving down the rate of return on capital until a stationary state emerges when the return on capital disappears and all of the produce of society is used either to maintain the population at a subsistence level or to pay rent on intramarginal land.

(Forget 1999: 160) 3

As for the main claim, while it cannot be gainsaid that Say focused less on the growth process than did his British contemporaries, what there is, we shall show, is in major respects shared property. Specifically, Say committed himself finally to the zero-rent, demand-determined margin - at least the extensive margin. Mahieu errs in my view when contrasting what he refers to as mutual 'incompréhension' regarding value theory with 'une opposition totale' between Say and Ricardo on rent (Mahieu 1992: 36). Say also came to adopt the falling profit rate due to the effect of rising wage-goods' costs on money wages, in brief the inverse wage-profit relation, admitting the untenability of Smith's 'increasing competition of capitals' doctrine as in conflict with the Law of Markets. However, by also subscribing to a strict subsistence-wage trend on the basis of hard-line Malthusianism, he fell short of the analytically more sophisticated and logical 'shared-incidence' principle (above, p. 2). And he frequently forgot his admission, reverting to Smithian elements antagonistic to the canonical system, including the effect of wage increase on prices rather than on profits.

Say's entrepreneur and the element of risk undertaken will appear on our stage. The secondary literature provides a disparate range of opinion on these issues. Steiner proposes 'to situate Say's conception of the entrepreneur in the time which, from R. Cantillon to F. Knight, stresses that the entrepreneur is 
fundamentally defined by his confrontation with uncertainty' (Steiner 1998a: 211). By contrast, Hébert and Link make the point that though, for Say, in carrying out his function [as "catalyst" in the production process] the entrepreneur frequently puts himself at risk . . this was not the main strain of his argument as it was for Cantillon' (Hébert and Link 1982: 32-3); in fact, the main source of entrepreneurial income is not profit as a premium for risk but rather a wage payment for a highly skilled type of labour' (34). In our view, and without in any way disparaging Say's contribution, the opinion of Hébert and Link regarding Say is convincing. ${ }^{4}$ Koolman's excellent and justifiably sympathetic account also comes to this conclusion (Koolman 1971). It is a perspective adopted by Knight himself in 1921. Knight refers to the British practice - Smith, Malthus, McCulloch and J. S. Mill are mentioned - of qualifying their usual identification of 'profit' and 'interest', by including within profits ('even normally') an element that is not interest on capital but remuneration for supervisory functions and risk in the sense of risk of loss of capital (Knight 1964 [1921]: 24-5). French practice was different:

The early French writers, beginning with J. B. Say, adopted a different view of profit, or at least a different use of the word, insisting on a separation of profit from interest and defining the former explicitly as a wage. The difference in procedure may have been due, as v. Mangoldt suggests, to the different character of typical French industry and the greater importance of the manager's personality in it relatively to the capital factor. It is worthy of note that in the fourth edition of his 'Traité, Say included in profit the reward for risk-taking; he had in the earlier editions viewed this income as accruing to the capitalist as such, but now transferred it to the entrepreneur.

Yet the point to note is that Knight himself goes on to maintain that it was not Say but Courcelle-Seneuil (in 1852) who 'glimpsed the fact . . that the assumption of a "risk" of error in one's own judgment, inherent in the making of a responsible decision, is a phenomenon of a different character from the assumption of "risk" in the insurance sense' (25n.). This too is consistent with von Mangoldt's reading of Say (Hennings 1980: 663-4).

Our discussion of the Law of Markets will trace the evolution of Say's position from its beginnings in 1803. Say is shown to have ascribed to the 'equality' rather than 'identity' version of the Law, allowing for disequilibrium states entailing excess demand for money to hold (above, p. 8), in fact going further than Ricardo by recognizing aggregate-demand contraction as a possible cause and not merely as an accompaniment of depression. Baumol seems to be rather too strict when he says that while Say recognized features of depression, he could find 'very little' regarding causation in Say's expositions (Baumol 2003: 42). At the same time, there is truth to Schumpeter's observation that Say could be his own worst enemy by expressing himself too strongly (Schumpeter 1954: 619). 
Our orientation is that of J. S. Mill who insisted that Say correctly applied the Law not to deny short-run disequilibrium states but to support the view of growth unhindered by constraints emanating from lack of aggregate demand, the concern of Sismondi and Malthus (Mill 1963-91 [1848], 3: 571f.). (For modern insistence on the secular context, see Baumol 1977: 160; Sowell 1987b: 250; Jonsson 1977: 205; Forget 1999: 170; 2003: 57.) From this perspective we consider the charge that while Ricardo, basing himself on James Mill, formulated the non-tautological proposition that 'general equilibrium of the economy with prices equal to costs (including "profit"), is compatible with any level of real income', Say remained on the level of pure tautology (Stigler 1965: 317-18). This turns out to be an unjustified criticism of Say who formulated the non-tautological version very early on. Chipman's evaluation (Chipman 1965) that the doctrinaire version of the Law belongs to James Mill is confirmed. As for the matter of intellectual debt, it has been affirmed that 'neither Ricardo nor Malthus ever attributed the origin of the Law of Markets to J. B. Say' (Forget 1999: 166; 2003: 53). In fact, Ricardo - explicitly and repeatedly - insisted on Say as originator of the Law.

In the course of our discussion attention will be accorded two posthumously published letters to Malthus - one of February 1827 in which Say is supposed to have 'recanted' the Law of Markets (Lambert 1956; Sowell 1972a: 77; 1974: 47-8; 1987a), and one dated July 1827 which has been read as warding-off challenge by a mere play of words (Lambert 1956; Baumol 1977; Thweatt 1979). As for the first, we show Say to be expounding Ricardian doctrine regarding a variety of constraints on secular expansion unrelated to any aggregate-demand constraint. All in all, the Ricardo-Say nexus in this regard turns out to be closer than I once argued (Hollander 1979: 506-7, 538). The July letter is indeed deficient but here and in other instances of terminological sleights-of-hand, Say does not do justice to his own case. We shall also address critically a particular theme recently argued by Forget that 'Say used the law in the context of the active creation of new, often foreign, markets by entrepreneurs' (Forget 2003: 51); and that 'Say's amalgamation of the law with his analysis of entrepreneurship allows us to distinguish his own use of the concept from that of the classical school' (60).

Throughout our study we will be faced by Say's formal charge against the British writers of excessive 'abstraction' similar in some respects to the complaints addressed by Schumpeter under the rubric 'the Ricardian Vice' (Schumpeter 1954: 473). It is, I believe, an unjustified complaint based on a failure to appreciate the nature of Ricardo's Principles which was intended not as a 'practical' monograph, but as a sort of textbook entailing often artificial constancies for purely analytical and pedagogic purposes. For Ricardian applied economics we must turn to his pamphlets, speeches and correspondence, where appropriate qualifications to the model in practical applications become apparent. All this was clear to Marshall: Ricardo in 
devising 'strong cases' was omitting the conditions and limitations that were needed 'to make his results applicable to real life' (Marshall 1920: 508-9); and to Dunbar: 'behind the abstract discussions of [Ricardo's] book lay a great reserve of facts and observations, ready to be drawn upon whenever the task at hand seemed to require it' (Dunbar 1886-7: 474-6). I have argued this point (Hollander 1979: 658-9) and it is reinforced by Davis in a study of Ricardo's monetary thought (Davis 2005).

Partly for the foregoing reason, Sowell's generalization that 'Say was a policy-oriented economist rather than a model-builder like Ricardo' (1987a: 249) is too strong. Magnan de Bornier and Tosi (2003) refer to Say's opposition to 'system-building' in favour of a 'practical' political economy (see also Legris and Ragni 2003). But there is enough evidence for us to doubt that so sharp a contrast is justified. Say, for example, paid much lip-service to verification; and his frequent willingness to draw strong practical conclusions from his conceptualization of economic process and his rather too casual treatment of so-called 'exceptions' to principle will be documented. These weaknesses are less apparent in the Law of Markets context, though it is precisely the chapter 'Des débouchés' that for Schumpeter reveals Say to be 'an addict of the Ricardian Vice' (Schumpeter 1954: 618). By and large, our position is that there was no substantive difference regarding method between Ricardo and Say, although Say did, of course, insist on a special role for political economy in modern society, the celebrated 'practical' dimension.

\section{Plan of work}

My analysis of value and related distribution issues will occupy Chapters 2 and 3, the first dealing with Say's position from 1803 until 1823 - the year of Ricardo's death - and the second with the fifth edition of the Traité (1826) and the Cours complet (1828-9). Considerable accord emerges regarding value - the primacy of supply in particular; and Ricardo's positive view of the 'doctrine of services' becomes apparent. I also document Say's formulation of several major canonical themes relating to distribution. In these exercises the Notes to the 1819 French translation of Ricardo's Principles (1817) and also the correspondence are heavily weighed in an attempt to understand the difficulties impeding mutual comprehension. For Say attributed to Ricardo positions the latter denied, specifically that he rejected the demand-supply determination of long-run price, and allowed only for labour in costs excluding not only rent but also the return on capital - the same attributions to Ricardo made by Malthus. Similarly, Ricardo protested at misreadings of his chapter 'On Gross and Net Revenue'.

The Say-Ricardo debate regarding 'riches' touched on only tangentially in the discussions of Chapters 2 and 3 regarding the positive theory of value - Say's insistence on an exchange index contrasting with Ricardo's utility index - is explored in Chapter 4. Here the substantive identity of Say's doctrine of services and Ricardian cost theory is confirmed. But beyond this 
we document the extensive common ground emerging when Say, changing the terms of reference from riches as a stock to riches as a flow of real income, effectively abandons his own in favour of Ricardo's position which denies the possibility of obtaining meaningful statistical measures of the concept. Thus Say's methodological case for the quantification of 'riches' breaks down. We also take account of Say's discussions with Malthus on this issue.

The Law of Markets is the subject of Chapter 5. Here Say's misunderstanding of Ricardo in attributing to him an extreme interpretation of the Law is conspicuous, though belatedly he did make partial amends. However, it is also apparent that Say himself was innocent of some of the charges laid against him in the literature, in particular that he emptied the law of all content by definitional sleights-of-hand.

Two final chapters summarise our evidence for a greater extent of common ground between Say and Ricardo than is generally envisaged regarding both methodology and doctrine, and cites J. S. Mill to this effect. But I do not in the end make a case for Say as an enthusiastic adherent to the canon. There are too many remaining Smithian features to allow such a case including attribution to agriculture of a peculiar national profitability, based on appeal to a hierarchy of investment priorities, and the interdependence of demand and supply in the case of corn due to the operation of the population mechanism. (In both these respects the differences with Ricardo parallel those between Malthus and Ricardo.) The inverse wage-profit relation is expounded by Say in 1819, yet he continued to argue the Smithian case for an effect of the wage on general prices; again, he then rejected Smithian increasing 'competition of capitals' only to forget in his later work that he had done so. And beyond this matter of internal paradigmatic conflict, Say increasingly sought to disguise what common ground existed, especially after Ricardo's death, by setting up a straw-man version of Ricardianism for easy disposal. This campaign, however, must not be understood, as often seems to be the case, as evidence of growing discord relating to substantive methodological and doctrinal matters, but rather - as we propose in a final chapter - may be better approached in psychological terms as a reflection of Say's sensitivity to criticism. 


\section{Value, distribution and growth before 1823}

Say's cost-price analysis 1803

A formulation of the Smithian market-natural-price distinction and the 'tendency' of the former to the latter by way of appropriate supply adjustments will be found in the Traité of 1803:

Le prix courant d'une marchandise tend toujours à se mettre au niveau de son prix naturel. Car lorsqu'il s'élève au-dessus du prix naturel, la production de cette marchandise, mieux payée que les autres productions, attire de ce côté des terres, des capitaux, de l'industrie; la quantité offerte augmente relativement à la quantité demandée, et le prix baisse.

(Say 1803, 2: 60)

Conversely, should market price fall below natural price, some or all services transfer to other industries, and the market price rises 'jusqu'à ce qu'il atteigne un taux où il puisse payer convenablement les services productifs'. The general principle is that 'la concurrence des producteurs réduit le prix courant au niveau du prix naturel, et le prix naturel détermine l'étendue des demandes qui sont faites de chaque produit' (72). By the same token, some goods were beyond the reach of the masses: 'Le prix de cette denrée ne baisse pas au niveau des facultés du peuple, parce que ce niveau est au-dessous de son prix naturel' (73). All this of course rehearses Smith's analysis in Wealth of Nations, Book I: vii. While frictions might impede transition between industries, disequilibrium states are temporary:

Je conçois que la circulation peut être obstruée par certains produits trop abondans; c'est un mal qui ne peut jamais être que passager, car on cesse bientôt de se livrer à une production, dont les produits excèdent les besoins et tombent dans l'avilissement, pour s'occuper de la production des denrées recherchées. 
It will be a matter of judgement whether such formulations - which again clearly derive from the Wealth of Nations - recognise the role of scarcity in long-run (natural) price determination. Forget, for example, allows Say's recognition of 'the role that scarcity plays in determining current price', but believes 'that there is no real recognition' of its role 'in the determination of natural price in the first edition of the Traité" (Forget 1999: 137). (She goes much further when she asserts tout court that 'Say did not emphasise the role of scarcity in his analysis, despite the fact that J. S. Mill found it there' (135).) To my mind, the role of scarcity is inherent in the notion of appropriate supply adjustment relative to the pattern of demand. Should there remain any doubt we may point to explicit use of the term 'bornes' (limits) in the natural-price context. Thus the chapter in question is entitled 'Que l'étendue de la demande est bornée par le prix naturel des produits', and commences: 'La demande des produits utiles ou agréables n'aurait . . . point de bornes, si l'on pouvait les obtenir sans les payer au moins suivant leur prix naturel' (Say 1803, 2: 69).

\section{Cost-price analysis 1814-17}

We turn to the Traité of 1814, and an important formulation of the rapid adjustment of market to cost price assured by commodity-supply responses to deviations between them. Implicit in this analysis - as in that of the Wealth of Nations - is the contrast between shifts in demand or supply schedules and movements in response to price changes given the schedules:

La concurrence des producteurs fait ordinairement tomber le prix des choses au niveau des frais de leur production [Note: Le montant des frais de production est ce que Smith appelle le prix naturel d'une chose.], dans lesquels je comprends les profits des producteurs, qui sont la rétribution qui leur revient pour le concours de leur fonds de terre, de leurs capitaux, de leur industrie, dans la formation de la chose produite. Si quelquefois le prix d'une chose tombe au-dessous de la valeur ou du prix de ses frais de production, c'est parce qu'il en a été produit par-delà les besoins, ou parce que les besoins ont diminué inopinément. Ce prix ne reste jamais bien long-temps trop bas; car dès lors la production de cet objet particulier donnant de la perte, on cesse de s'y livrer; il ne s'en produit plus, ou s'en produit moins, ce qui diminue la quantité offerte.

(Say 1814, 2: 5)

The increased quantity demanded at lower cost price is elaborated in what follows immediately:

Le prix qui s'établit ainsi concourt à déterminer l'étendue de la demande, qui augmente à mesure que le produit baisse; parce qu'à mesure que le produit baisse, il tombe au niveau des facultés d'un plus grand nombre de 
consommateurs. On vient de voir qu'il ne baisse d'une manière durable, qu'autant que les frais de production viennent à diminuer.

A carefully expressed notion of costs, rather than utility, as 'determinant' of value - by acting as limit to 'gratuitous enjoyment' - is formulated in the 1814 edition, and attracted the favourable attention of Ricardo. Ricardo sets off with a free summary of his understanding of Say:

utility is the foundation of value ... commodities are only desirable, because they are in some way useful, but ... their value depends not on their utility, not on the degree in which they are desired, but on the quantity of labour necessary to procure them.

(Ricardo 1951-73, 1: 287n.)

This summary is a faithful rendition of the following formulation apart from the specification 'quantity of labour' since Say refers also to land and capital:

L'utilité d'une chose ... la rend désirable aux yeux des hommes, la fait souhaiter, établit une demande de cette chose. Lorsqu'il suffit de la désirer pour l'obtenir, elle peut être considérée comme une richesse naturelle livrée sans mesure aux besoins de l'homme, et dont il jouit sans l'acheter au prix d'aucun sacrifice: tels sont l'air, l'eau, la lumière du soleil. S'il obtenait ainsi les objets de tous ses besoins et de tous ses désirs, il serait infiniment riche; rien ne lui manquerait.

Malheureusement il n'en est pas ainsi; la plupart des choses qui lui sont, je ne dis pas seulement commodes et agréables, mais indispensablement nécessaires ... ne lui sont pas accordées gratuitement [1817: ... accordées en quantité illimitée]; elles n'ont pu exister que par le moyen d'un certain travail [1817: sans le concours d'un travail humain], l'emploi d'un certain capital [1817: d'un capital accumulé\}, et, dans beaucoup de cas, l'usage d'un fonds de terre.

(Say 1814, 2: 3; 1817, 2: 3)

Say summarised in 1814 in terms of a simple cost constraint: "Voilà des difficultés opposées à la jouissance gratuite de ces choses, des difficultés desquelles il résulte de véritables frais de production; car il faut bien payer le concours de ces agens de la production.' A similar passage also pleased Ricardo who italicized the key concepts, as he saw them, in his translation:

Ainsi toutes les choses qui ont de l'utilité pour l'homme ne sont pas des produits; elles ne sont des produits qu'autant que cette utilité leur a été communiquée par l'action de ce que nous avons nommé les agens de la production, c'est-à-dire, l'industrie, les capitaux et les terres. C'est seulement lorsque cette utilité a été communiquée ainsi à une chose qu'elle 
est un produit, et qu'elle a une valeur [and that it has a value]. Son utilité établit la demande qu'on en fait; mais les sacrifices, les frais qu'il faut faire pour l'obtenir, ou en d'autres termes, le prix qu'il faut y mettre [but the sacrifices, and the charges necessary to obtain it, or in other words, its price], bornent l'étendue de cette demande.

(Say 1814, 2: 4)

The cost orientation is amply confirmed in early correspondence with Ricardo. In a letter of 18 August 1815, Ricardo objected to a passage in the first edition of Say's Catéchisme d'Economie Politique (1815) which he read as taking 'the degree of utility' to be the 'measure' - the sense is actually the determinant - of value:

Utility is certainly the foundation of value, but the degree of utility can never be the measure by which to estimate value. A commodity difficult of production will always be more valuable than one which is easily produced although all men should agree that the latter is more useful than the former. A commodity must be useful to have value but the difficulty of its production is the true measure of its value. For this reason Iron though more useful is of less value than gold.

(Ricardo 1951-73, 6: 247-8) ${ }^{1}$

To this criticism Say responded (10 September 1815) that Ricardo had misunderstood him, since he in fact fully agreed regarding the status both of utility as 'première cause' (Ricardo's 'foundation of value') and cost as determinant - subject to the utility engendered by the product justifying the outlays - the misunderstanding arising from Say's attempt to convey elementary propositions to beginners leaving qualifications to a later stage of the exposition: 'Je dis donc comme vous, que les frais de production d'une chose, déterminent la plus basse limite de son prix; mais ils ne sont pas la cause première du prix qu'on en offre' (Say, in Ricardo, 1951-73, 6: 271). Say concludes: 'Il me semble qu'il n'y a rien là de contraire à ce que vous établissez.' In an alternative version of this letter dated 2 December Say makes the same point:

Je conviens de même, avec vous, que la valeur d'un produit ne peut pas baisser au-dessous de ce que coûtent les difficultés de sa production. Si les hommes estiment que son utilité vaut ce prix-là, ils le produisent; s'ils estiment que son utilité ne vaut pas ce prix-là, ils ne le produisent pas.

The extract from the Traité of 1814 stressing obstacles to 'gratuitous enjoyment' imposed by scarce labour, land and capital is repeated almost without change in the third edition of 1817 (see above, p. 27). The brief summary that follows the reference to the contribution of these factors is, 
however, altered to read: 'concours auquel nous avons donné le nom de service productif de l'industrie, des capitaux et des terres' (1817, 2: 3). This replacement of the term costs is simply of a terminological nature since the two formulations come to the same thing, as is readily seen from the Epitome des principes fondamentaux in both editions:

La production a lieu par les services productifs que rendent les trois grands agens de la production (l'industrie, les capitaux, les terres). Ces services productifs ayant une valeur, la production peut être considérée comme un échange de la valeur des services productifs, ou des frais de production, contre leurs produits.

The rapid tendency of market to cost price is also reformulated in 1817 , even reinforced:

La concurrence des producteurs entre eux tend sans cesse à faire baisser la valeur des produits au niveau de leurs frais de production, qui se composent de la valeur de tous les services productifs qui ont concouru à la création de ce produit. ... Il est difficile en effet que l'un de ces produits demeure long-temps hors de proportion avec ses frais de production; car les producteurs afflueraient vers la production d'un produit qui donnerait de plus gros profits qu'un autre, et se retireraient de la production de celui qui ne leur donnerait que des profits inférieurs.

$(1817,2: 8-9)$

The increased quantity demanded at a lower cost price follows immediately in the same terms as in 1814.

$$
* * *
$$

Say had little to offer on distribution theory as such at the time of the appearance of Ricardo's Essay on Profits. But in the alternative version of the letter of 10 September 1815, dated 2 December (see note 2), he opined that the theory of profit and rent was of small importance compared with the return to 'le talent, la capacité industrielle', doubtless a reference to entrepreneurship, though he did not feel yet sufficiently sure of his own position:

Que vous dirai-je à l'égard de votre polémique avec M. Malthus? Vous avez l'un et l'autre étudié la question of rent and profits sans doute beaucoup mieux que moi; et puis je vous confesse que ma façon d'envisager les profits, soit d'un capital, soit d'un fonds de terre, rend très difficile pour moi la tâche de débrouiller cette question. Je ne peux m'empêcher de faire entrer pour beaucoup, dans l'appréciation des profits, le talent, la capacité industrielle de celui qui fait valoir un terrain ou un capital; 
et je regarde comme comparativement peu important le profit propre, le profit inhérent à ces deux instruments. Au surplus, je dois me défier beaucoup de mon opinion, et je crains de l'énoncer à côté de la vôtre.

(in Ricardo 1951-73, 6: 274)

\section{The Notes (1819) on Ricardo's Principles: cost price}

Say's annotations of the first edition of Ricardo's Principles were begun in mid-1817 and designed for use in the projected fourth edition of the Traité that appeared in 1819. In the event, they were added to the French translation of Ricardo's Principles (1817) by Constancio that also appeared in 1819. (On these details see Appendix I.)

We start with the notion of 'cherté réelle' appearing in the Notes and alluding to the Traité of 1817. The formulation, while confirming Say's own cost orientation, inexplicably charges Ricardo with failing to appreciate the notion of real value and the fact that should technical change reduce all commodities in 'cherté réelle' there may occur no relative price alterations: 'Il y a une cherté propre, une cherté réelle indépendamment de la valeur relative des choses, et cette cherté propre est en raison des frais de production. (Voyez le Traité d'Économie politique [1817]. liv. II, chap. 4)' (Say 1819b, 1: 277); 'la baisse du prix d'un produit est réelle lorsque, avec les mêmes moyens de production, les mêmes frais de production, le même terrain, le même capital, le même travail, on obtient une plus grande quantité de produits' (364);

une marchandise ... est chère, lorsqu'elle est le résultat de beaucoup de frais de production, du service de beaucoup de capitaux ou d'industrie. ... C'est une preuve de plus qu'il y a autre chose que des variations relatives dans les prix, comme toute la doctrine de M. Ricardo semble l'établir.

Despite his 'cherté réelle', in one Note Say seems to deny any regular tendency of market to natural price or, more accurately, he jettisons these concepts. For the exchange of products is portrayed as reducing to an exchange of productive services (a standard theme in the Traité), leading to the representation of the contrast between market and natural price as 'chimérique' since there are only current prices in the system including the prices of services. Here Say emphasises derived demand and says nothing of service-supply conditions:

La distinction entre le prix naturel et le prix courant que M. Ricardo admet après Smith, paraît être tout-à-fait chimérique. Il n'y a que des prix courans en Économie politique. En effet, que voyons-nous dans toute espèce de production? 1 . des services productifs fonciers (l'action 
productive de la terre), dont le prix courant s'établit comme la valeur de toute autre chose, en raison composée de la quantité de ce service, offerte et demandée en chaque lieu; 2 . des services rendus par des capitaux productifs dont le prix courant, le loyer, se règle sur les mêmes motifs; 3. enfin des travaux de tout genre, dont le prix courant dépend des mêmes causes.

Qu'est-ce qui établit la demande du service productif de ces divers agens? La demande qu'on fait du produit qui doit en résulter. Et qu'estce qui établit la demande de ce produit? Le besoin qu'on en a, l'utilité dont il est.

Mais comme on n'achète un produit qu'avec un autre produit, et que le produit qui achète n'a pu exister de son côté que par des services productifs analogues à ceux qui ont donné naissance au premier, les hommes qui composent la société ne font, dans la réalité, qu'offrir les services productifs propres à un genre de production, en échange des services productifs propres à un autre genre, propres à créer le produit dont ils ont besoin, - et par services productifs j'entends non-seulement les services que rend le travail que l'auteur [Ricardo] aurait dû nommer industrie, mais de plus les services que rendent les capitaux et les terres.

Il en résulte, pour chaque genre, une quantité d'offres et de demandes qui règle la valeur courante, le prix courant de tous ces différens services. Il n'y a point là de prix naturel, de taux commun et fixe, parce qu'il n'y a rien de fixe dans ce qui tient aux valeurs. Ce n'est pas un prix que le taux auquel une chose ne se vend pas; et si elle se vend à ce taux, ce taux devient son prix courant. Tout le reste est hypothétique et de peu d'usage dans la pratique.

(Say 1819b, 1: 125-7)

Now, if one looks closely at the passage in Ricardo on which Say is commenting, there will be found nothing at odds with Say's insistence that service prices themselves are indeed prices determined by demand and supply; it is only that Ricardo decides for his analytical purposes to set aside 'accidental' disturbances:

In the 7th chap. of the Wealth of Nations, all that concerns this question is most ably treated. Having fully acknowledged the temporary effects which, in particular employments of capital, may be produced on the prices of commodities, as well as on the wages of labour, and the profits of stock, by accidental causes, without influencing the general price of commodities, wages, or profits, since these effects are equally operative in all stages of society, we leave them entirely out of our consideration, whilst we are treating of the laws which regulate natural prices, natural wages and natural profits, effects totally independent of these accidental causes. In speaking then of the exchangeable value of commodities, or the power of purchasing possessed by any one commodity, I mean always that 
power which it would possess, if not disturbed by any temporary or accidental cause, and which is its natural price.

(Ricardo 1951-73, 1: 91-2)

We shall later also document Ricardo's acceptance of Say's 'doctrine of services' (below, p. 58). The question to be addressed now is whether or not Say, by his dismissal of the market-natural dichotomy, intended to deny a regular tendency of market to cost price such as Ricardo - following Smith - insisted on, and such as he himself expounded in 1803, 1814 and 1817.

It will become clear in what follows that, though Say disliked the term 'natural price', cost pricing remained part and parcel of his analysis. But costs determine only the scarcity or supply conditions of a product, and he took issue with the view he attributed to Ricardo that costs alone determine exchange value, demand playing no role:

M. Ricardo me semble à tort ne considérer ici qu'un des élémens de la valeur des choses, c'est-à-dire le travail, ou, pour parler plus exactement, l'étendue des sacrifices qu'il faut faire pour les produire. Il néglige le premier élément, le véritable fondement de la valeur, l'utilité. C'est l'utilité qui occasionne la demande qu'on fait d'une chose. D'un autre côté, les sacrifices qu'il faut faire pour qu'elle soit produite, en d'autres mots, ses frais de production, font sa rareté, bornent la quantité de cette chose qui s'offre à l'échange. Sa valeur s'élève d'autant plus qu'elle est plus demandée et moins offerte, et s'élève d'autant moins qu'elle est moins demandée et plus offerte. Ce principe est fondamental en économie politique; il est confirmé par une expérience constante; il est expliqué par le raisonnement (Voyez mon Traité d'Économie politique [1817], Liv.II, ch. 1). Ce ne sont donc pas les frais de production seuls, ce que M. Ricardo, d'après Smith, appelle le prix naturel d'une chose qui règle sa valeur échangeable, son prix courant, si l'on veut exprimer cette valeur en monnaie.

(Note to Ricardo 1951-73, 1: 13) (Say 1819b, 1: 9-10)

This formulation appearing near the outset of the Notes, whereby costs including labour, capital and land - govern scarcity conditions, is repeated again at the close, in response to Ricardo's formal contrast (Ricardo 1951-73, 1: 385) between so-called 'monopolized' commodities subject to demand-supply analysis and commodities 'subject to competition' - 'whose quantity may be increased in any moderate degree' - and whose prices 'will ultimately depend, not on the state of demand and supply, but on the increased or diminished cost of production':

La quantité de travail, de capitaux et de terrain nécessaires pour accomplir un produit constitue la difficulté de sa production, sa rareté. Un produit qui ne peut être le fruit que de beaucoup de services productifs est plus rare que celui qui peut être le fruit de peu de services; en 
d'autres termes, un produit est d'autant plus abondant, que la même quantité de services productifs en fournit davantage. De là une plus grande quantité offerte, un prix plus bas. Lorsqu'au contraire, la quantité de services nécessaires augmente, le prix s'élève.

(Note to Ricardo 1951-73, 1: 385) (Say 1819b, 2: 296)

And to confirm the role of costs, Say as always treats the effect of a technical change using his own terminology, arriving - without mentioning the fact at precisely the same conclusions as Ricardo:

Une plus grande puissance de produire équivaut à une plus grande quantité de services productifs versés dans la circulation. Si quelque grand perfectionnement en agriculture me permet d'obtenir trente-six livres de blé là où je n'en obtenais que dix-huit, c'est comme si je doublais l'offre de mes services propres à faire du blé. Ils baisseront de moitié, et l'on pourra obtenir alors dix-huit livres de blé pour une demilivre de café seulement. Les services productifs propres à faire dix-huit livres de blé vaudront autant que les services productifs propres à faire une demi-livre de café. ${ }^{3}$

(Say 1819b, 2: 296-7)

Say sometimes posits limiting or extreme situations where the supply price rises to levels exceeding all possible demand prices so that the commodity is not produced at all: 'Je ne pense point que ce soient les frais de production qui définitivement règlent le prix des choses; car, lorsqu'une chose coûte trop cher à faire, elle ne se vend point' (1819b, 1: 79; see also $85-6)$. But this is scarcely a serious objection to cost-price analysis.

Forget maintains that '[o]nly Malthus seemed to argue that Ricardo rejected demand and supply in determining the long-run cost of production' (Forget 1999: 272). But Say too neglected Ricardo's insistence in the increasing-cost case that the agricultural margins are demand determined (see above, p. 7). He had fallen into a standard misreading of Ricardo - indeed, he may be considered one of the sources of this misreading. For whereas Ricardo was expounding the priority of supply conditions in determining long-run price, Say understood him as positively eliminating demand:

La plupart des Economistes politiques établissent que la valeur ou le prix d'une chose s'élève ou s'abaisse en raison directe de la demande qui en est faite, et en raison inverse de l'offre. M. Ricardo affirme que l'offre et la demande n'y font rien; que le prix baisse par la concurrence des producteurs jusqu'au niveau des frais de production, et s'arrête là.

(Say 1819b, 2: 294-5)

Similarly, that Ricardo's analysis of long-run price ran counter to demandsupply principles is asserted in a criticism of Ricardo's proposition that land 


\section{Value, distribution and growth before 1823}

taxes, pace Adam Smith, do not affect rent or agricultural profits but are 'compensated by the rise of raw produce' (Ricardo 1951-73, 1:184): ' ' [C]'est qu'il admet pour la fixation des prix d'autres bases que la quantité offerte et la quantité demandée de chaque chose en chaque lieu, quoiqu'il n'y en ait point d'autre' (Say 1819b, 1: 305). But Say should have realized his misunderstanding, since he himself allows that Ricardo all but appreciated the 'correct' position in writing of paper money that ' $[\mathrm{t}]$ hough it has no intrinsic value, yet, by limiting its quantity, its value in exchange is as great as an equal denomination of coin' (Ricardo 1951-73, 1: 353):

Cet exemple devrait suffire, ce semble, pour convaincre l'auteur que la base de toute valeur est, non pas la quantité de travail nécessaire pour faire une marchandise, mais le besoin qu'on en a, balancé par la rareté. Le travail, ou en général les frais de production, sont une difficulté à vaincre qui borne la quantité d'une marchandise qu'on peut apporter sur le marché, et c'est en ce sens qu'ils sont un des élémens de la valeur des choses.

(Say 1819b, 2: 234)

This statement of the role played by supply constraints is, of course, entirely 'canonical'. And we conclude that the Notes of 1819 contain no substantive differences with Ricardo on the principle of long-run cost determination (apart from the elements that comprise costs).

* * *

We now return to the passage cited above (p. 32) from the Notes (1819b, 1: 9-10). Say proceeds to the 'Marshallian' conclusion that in cases of rising supply price, an exogenous increase in cost will not bring about an 'equivalent' - in the sense of proportionate - price increase, and this because of the effect of a higher price on quantity demanded. The effect of price on demand had been neglected by Ricardo, Say added diplomatically:

Lorsque les frais de production augmentent, pour que la valeur échangeable augmentât aussi, il faudrait que le rapport de l'offre et de la demande restât le même; il faudrait que la demande augmentât aussi; et il est de fait qu'elle diminue; il est impossible, toutes circonstances étant d'ailleurs les mêmes, qu'elle ne diminue pas. La valeur échangeable ne peut donc pas monter comme les frais de production. C'est pour avoir perdu de vue ce fait constant et, par conséquent, ce principe fondamental, que M. Ricardo a été entraîné, je crois, dans quelques erreurs, que je prendrai la liberté de relever dans l'intérêt de la science, et sans m'écarter des égards que mérite l'auteur par ses qualités personnelles autant que par ses talens.

(Say 1819b, 1: 10) 
An exogenous cost increase is well illustrated by a tax, and Say maintained in a Note on Ricardo (1951-73, 1: 220) that tax-incidence analysis portrayed the contrast between his own methodological approach and Ricardian oversimplifications (Say 1819b, 1: 380). The incidence of a tax between consumer and producer was a complex matter, depending on relative price elasticities:

L'impôt aura porté en partie sur les producteurs, entrepreneurs et ouvriers, mais dans des proportions fort diverses; en raison de la diminution de leurs gains, et en partie sur les consommateurs, à cause de l'augmentation du prix, et la production de cet article, comme sa consommation, auront diminué.

This result, he was 'sadly' obliged to conclude, undermined Ricardo's approach:

cet effet, résultat de la nature des choses et du raisonnement qui l'explique suffisamment, ébranle, je le dis avec chagrin, l'édifice que $\mathrm{M}$. Ricardo, non-seulement dans ce chapitre, mais dans quelques autres, élève avec beaucoup d'habileté sur des principes trop absolus.

Now the fact is that Ricardo also recognized a variety of outcomes involving demand elasticity. For example:

It is undoubtedly true, that a taxed commodity will not rise in proportion to the tax, if the demand for it will diminish, and if the quantity cannot be reduced. If metallic money were in general use, its value would not for a considerable time be increased by a tax, in proportion to the amount of the tax, because at a higher price, the demand would be diminished, and the quantity would not be diminished.

(Ricardo 1951-73, 1: 220; emphasis added)

Ricardo should have written that assuming a negatively-sloped demand curve and a given supply, the price will not rise at all, but this he in fact appreciated as is clear from the case of a tax on corn in the case where maximum output has been reached:

At such time ... any tax which may be imposed on the farmer, will fall on rent, and not on the consumer. He cannot raise the price of his corn, because, by the supposition, it is already at the highest price at which the purchasers will or can buy it. He will not be satisfied with a lower rate of profits, than that obtained by other capitalists, and, therefore, his only alternative will be to obtain a reduction of rent, or to quit his employment. 
So far so good. But in discussing Say's shared-incidence analysis in the Traité, whereby sellers cannot pass on the entire tax considering the effect of higher price on consumption, Ricardo objected:

should the consumption be diminished, will not the supply also speedily be diminished? Why should the manufacturer continue in the trade, if his profits are below the general level? M. Say appears here also to have forgotten the doctrine which he elsewhere supports [Say 1814, 2: 26], 'that the cost of production determines the price, below which commodities cannot fall for any length of time, because production would be then either suspended or diminished'.

(Ricardo 1951-73, 1: 243n.)

Yet Say certainly did allow for contraction of output, as is made very clear in a passage actually cited in translation by Ricardo himself:

un impôt quelconque mis sur un produit, n'en élève pas le prix total de tout le montant de l'impôt. Il faudrait pour cela que la demande totale restât la même; ce qui est impossible. L'impôt, dans ce cas, porte donc en partie sur le consommateur qui paye le produit plus cher, et en partie sur le producteur qui, l'impôt déduit, se trouve l'avoir moins vendu. Le trésor public profite de ce que le consommateur paye de plus, et du sacrifice que le producteur est obligé de faire d'une partie de ses profits.

(Say 1814, 2: 333; emphasis added)

Ricardo's objection is surprising. ${ }^{6}$ It implies that, in his view, the burden of taxation falls entirely on consumers. This is true assuming a negativelysloped demand curve and infinitely-elastic supply reflecting constant costs. But, as we have seen (above, p. 6), Ricardo himself recognized that in the event of given supply, the burden falls entirely on producers; and elsewhere in his Principles he makes the point that the extent of any price rise will depend in part on responsiveness of supply:

In proportion as the supply of a particular commodity can be more easily reduced, without inconvenience to the producers, the price of it will more quickly rise after the difficulty of its production has been increased by taxation, or by any other means.

(Ricardo 1951-73, 1: 191) $)^{7}$

All in all, Say's tax-incidence analysis is an impressive achievement, proceeding in general terms in contrast with Ricardo's frequent appeal to limiting elasticity values. Moreover, the facility with which he undertakes the analysis implies appreciation of the contrast between movements along and shifts of the demand and supply curves, a matter we shall take up in Chapter 3. 
We return to the Notes and Say's reaction to a criticism by Ricardo of the Traité for adopting the Smithian proposition that 'wages regulate price' (Ricardo 1951-73, 1: 74). ${ }^{8}$ In the chapter 'Taxes on Wages' Ricardo makes the same complaint:

M. Say appears to have imbibed the general opinion on this subject. Speaking of corn, he says, 'thence it results, that its price influences the price of all other commodities. A farmer, a manufacturer, or a merchant, employs a certain number of workmen, who all have occasion to consume a certain quantity of corn. If the price of corn rises, he is obliged to raise, in an equal proportion, the price of his productions [Say 1814, 1:255].

Now, paradoxical as it may seem, Say in his Notes formally supports Ricardo, arguing in terms of the significance of a negatively-sloped demand curve to make the case for some, if only a small, effect on price of a wage increase:

Au surplus, je crois, avec M. Ricardo, que la valeur des salaires, dans la plupart des cas, influe, sinon point du tout, au moins faiblement, sur la valeur des produits. Toute augmentation dans les frais de production diminue l'avantage que l'entrepreneur d'un certain produit en particulier trouve à le produire, diminue, par conséquent, la quantité de ce produit qui est apportée sur le marché et, par suite, en fait monter le prix; mais, d'un autre côté, à mesure que le prix monte, la demande diminue de son côté. C'est ce qui fait que les producteurs ne peuvent jamais faire supporter au consommateur la totalité de l'augmentation de leurs frais.

(Say 1819b, 1: 80)

But this agreement is a partial one only; for Say is not dealing here with the case Ricardo had in mind. Thus, Ricardo's denial that a wage increase 'regulates' price refers to a general wage rise and its effect on commodity prices in general; assuming uniform factor ratios a general wage increase leaves prices unaffected, while allowing for differentials it alters the structure of prices. Say is dealing in the passage just cited with a wage increase peculiar to one industry 'l'entrepreneur d'un certain produit' - and concludes that it cannot be passed on fully to consumers. Now for Ricardo as well as for Say (and Smith) it is indeed true that a wage increase peculiar to a particular industry necessarily raises cost price to prevent a fall in the rate of return on capital below the general level. But as for the effect of a general wage increase on prices, while the particular statement from the Traité cited critically by Ricardo is omitted in the 1819 edition and thereafter - this suggests perhaps some second thoughts the principle remains on the books elsewhere, as is clear from a rhetorical question relating to the 1815 Corn Law debate posed by Say: 
Ou bien fallait-il, en prohibant les grains étrangers, donner aux fermiers une prime aux dépens des consommateurs, augmenter pour l'ouvrier la difficulté de subsister, et, par le haut prix des denrées de première nécessité, renchérir encore tous les produits manufacturés de l'Angleterre, et leur ôter la possibité de soutenir la concurrence de ceux de l'étranger?

(Say 1817, 1: 262; 1819a, 1: 282; also 1826a, 1: 334-5)

* * *

Say himself, we have amply confirmed, subscribed in his Notes to a cost theory of price though convinced that, by stating the analysis in demand-supply terms, he was diverging in a major way from Ricardo. We now look more closely at Say's own attempt at one point to discover the source of what could only be, he says, a matter of misunderstanding considering an identity of method and general good judgement:

Lorsque divers auteurs, qui suivent les mêmes méthodes d'investigation et qui ont fait preuve de jugement en plusieurs occasions, different complètement d'avis sur un principe, leur dissentiment ne peut venir que faute de s'entendre. Essayons si l'on peut, dans ce cas-ci, de présenter la question sous un jour nouveau qui rallie toutes les opinions.

$\left(\right.$ Say 1819b, 2: 294) ${ }^{10}$

In his accommodating elaboration, Say again confirms his own adherence to a cost explanation of price but in such away as to allow within costs for the return to specialized factors - in the example that he gives 'les services propres à produire du café' - or what we have called the 'pseudo-cost' case:

Mais que fait-on, dans la réalité, lorsqu'on demande à échanger une marchandise contre une autre ... ? Il offre les services productifs (ou leur prix, c'est-à-dire les frais de production) qui ont servi ... à payer les services productifs dont la livre de café est le résultat.... Et quand M. Ricardo dit qu'un produit vaut toujours ce que valent ses frais de production, il dit vrai; mais la question reste à résoudre: Qu'est-ce que valent ces frais de production? Quel prix met-on aux services capables de produire un produit appelé une livre de café?

Je réponds qu'on y met d'autant plus de prix et qu'on est disposé à les payer d'une quantité d'autant plus grande de tout autre service productif, que les services propres à produire du café sont plus rares et plus demandés, et c'est dans ce sens qu'il faut entendre la demande et l'offre, le besoin et l'approvisionnement, le principe si connu des Anglais sous les noms de want and supply.

(Say 1819b, 2: 295-6) 
In all probability, Say's intention by focusing here on specialized factors was to reveal as clearly as possible that the elements composing costs, including profits, are themselves determined by the demand-supply process. This perspective emerges also in a criticism of Ricardo on the 'natural price' of the precious metals (Ricardo 1951-73, 1: 86), where - as is so usual with him - Say writes as if Ricardo excluded profits from costs, with labour input alone accounting for relative price:

Si la quantité de travail industriel nécessaire pour se procurer les métaux précieux déterminait seule leur valeur, cette valeur, au lieu de décroître comme elle a fait depuis deux cents ans, se serait accrue; car ces frais d'extraction ont été toujours plus considérables à mesure que les mines se sont approfondies.

(Say 1819b, 1: 110-11)

The Notes do, nonetheless, provide extensive elaborations of the tendency towards uniformity of returns based on alternative opportunities. This matter must be carefully established since Say approaches the Ricardian assumption critically on methodological grounds:

J'ai déjà eu l'occasion de remarquer que M. Ricardo admet trop généralement et sans restriction que les capitaux et l'industrie se retirent d'une production qui ne donne pas des profits égaux aux profits des autres commerces.... Il est impossible de négliger des circonstances qui influent si puissamment sur les résultats; on risque beaucoup de se tromper quand on n'a les yeux fixés que sur quelques grands principes, et qu'on ne veut compter pour rien les modifications qu'ils reçoivent des considérations accessoires. Les circonstances agissent en vertu de principes tout aussi incontestables et qui, de même que les principes les plus généraux, dépendent de la nature des choses.

(Note on Ricardo 1951-73, 2: 243) (Say 1819b, 2: 3-4)

There is also a discussion of Ricardo's proposition that a tax on agricultural produce must be passed on to consumers to prevent the agricultural return falling below the general return, where Say refers to the empirical problem of capital mobility:

Peut-être M. Ricardo [1951-73, 1: 166] ne tient-il pas assez de compte de la difficulté que les capitaux ont, dans beaucoup de cas, pour changer d'emploi. Un très-grand nombre d'entrepreneurs d'industrie ... sont obligés de faire marcher leurs capitaux avec eux, c'est-à-dire de les laisser dans l'emploi où ils restent eux-mêmes.

(Say 1819b, 1: 269-70) 
This was the case whether the entrepreneur used his own or borrowed capital. In the latter case,

il en paye bien toujours l'intérêt, mais il n'y fait point de profit par delà les intérêts; il peut même en tirer moins de profit qu'il n'en paye d'intérêts, sans cependant interrompre durant de nombreuses années une entreprise qui, à capital égal, à mérite égal dans son entrepreneur, rapporte moins que beaucoup d'autres entreprises.

Now it is all very well moralising in these terms, but the fact is that Say in his own analysis of tax incidence assumes capital mobility, as we have seen earlier and as he himself affirms in a denial that the burden of a tax on hats can fall entirely on producers: 'il faudrait que les producteurs payassent en totalité l'impôt sur leurs gains; or, cette circonstance, rendant cette production moins avantageuse, diminuerait la quantité offerte des moyens de production des chapeaux' (381). And Say assumes capital mobility with explicit allusion to alternative opportunities in treating taxation of agriculture. Exception is made for permanent land improvements - which, of course, is precisely Ricardo's exception. Such investment, usually undertaken by landlords, 'est tellement engagé dans la terre à laquelle il a été consacré, qu'on ne peut plus l'en séparer; c'est une valeur ajoutée à la valeur du sol, et qui en subit toutes les chances, bonnes ou mauvaises' (Say 1819b, 2: 32-3). The return takes on the character of rent Say should have said Ricardian rent - in contrast to the return to the mobile factors labour ('l'industrie') and capital:

Or, je dis que lorsqu'une terre est directement ou indirectement grevée d'impôts, ce n'est pas le profit de l'industrie et du capital du fermier qui en supporte le faix, parce qu'alors ses talens, ses travaux et son argent, qui se sont mis en avant pour un métier où l'on gagnait autant que dans tout autre, cetera paribus, abandonneraient une terre qui ne leur offrirait plus que des profits inférieurs, s'il fallait en déduire de nouvelles charges. Dès lors, au premier renouvellement de bail, il faudrait bien que le propriétaire baissât le prix de son bail; autrement il ne trouverait point de locataires.

(Note on Ricardo, 1951-73: 1: 255-6) (Say 1819b, 2: 33)

A further instance of common ground on the matter of capital mobility, uniformity of profit rates and cost price emerges in the analysis of the effects of protection. Say maintained in his Traité that protection forces market price above 'le taux naturel' in the affected industry, thereby increasing the profit rate:

Un gouvernement qui défend absolument l'introduction de certaines marchandises étrangères, établit un monopole en faveur de ceux qui 
produisent cette marchandise dans l'intérieur, contre ceux qui la consomment; c'est-à-dire, que ceux de l'intérieur qui la produisent, ayant le privilège exclusif de la vendre, peuvent en élever le prix au-dessus du taux naturel, et que les consommateurs de l'intérieur, ne pouvant l'acheter que d'eux, sont obligés de la payer plus cher.

(Say 1814, 1: 200-1; 1817, 1: 197; 1819a, 1: 209)

For Ricardo, protection obliges production at lower efficiency than the foreign equivalent. Thus ' $[t]$ he price, though permanently higher, was not sustained by scarcity' - intending a constraint on domestic output - 'but by difficulty of production; and, therefore, though the sellers of such commodities sold them for a higher price, they did not sell them, after the requisite quantity of capital was employed in producing them, at higher profits' (Ricardo 1951-73, 1: 316).

On this matter Say admitted error in a note in the 1819 edition of the Traité (without altering the text) and in a Note to Ricardo's Principles:

M. David Ricardo ... observe avec raison, à l'occasion de ce passage, que le gouvernement ne saurait, par une prohibition, élever un produit audessus de son taux naturel; [1819b: M. Ricardo me paraît avoir ici raison contre moi. En effet, quand le gouvernement prohibe un produit étranger, il ne saurait élever dans l'intérieur les bénéfices qu'on fait sur sa production au-dessus du taux commun des profits; ] car alors les producteurs de l'intérieur, en se livrant à ce genre de production, en ramèneraient bientôt, par leur concurrence, les profits au niveau de tous les autres.

(Say 1819a, 1: 209n.; 1819b, 2: 161)

He then restated his position in Ricardo's terms precisely, though implying that there remained a difference between them. Protection raises cost price to the detriment of consumers but with no benefit to producers in consequence of capital mobility into the protected industry:

Je dois donc, pour expliquer ma pensée, dire que je regarde le taux naturel d'une marchandise, comme étant le prix le plus bas auquel on peut se la procurer, soit par la voie du commerce, ou par toute autre industrie. Si l'industrie commerciale peut la donner à meilleur marché que les manufactures, et si le gouvernement force à la produire par les manufactures, il force dès lors à préférer une manière plus dispendieuse. C'est un tort qu'il fait à ceux qui la consomment, sans qu'il résulte pour le fabricant indigène un profit équivalent à ce que le consommateur paie de plus; car la concurrence intérieure force le fabricant à réduire ses profits au taux général des profits. Il ne jouit d'aucun monopole. [1819b: C'est un tort qu'il fait à ceux qui la consomment, mais ce n'est pas au profit de ceux qui la produisent.] C'est à ce point de vue que la 
critique de M. Ricardo est fondée; mais la mesure que je combats n'en est que plus mauvaise; elle augmente la difficulté naturelle qui s'oppose à la satisfaction de nos besoins, et c'est sans profit pour personne.

(Say 1819a, 1: 209-10n.; 1819b, 2: 161-2)

Say's costs thus include profits paid at the uniform rate. This, of course, is also the case for Ricardo, although Say repeatedly alleged in his Notes that Ricardo had allowed only for labour; and though we have encountered the treatment of rent as surplus, it too appears within costs in some formulations: 'M. Ricardo [1951-73, 1: 25] ne comprend, dans ce qu'il nomme, d'après Smith, le prix naturel des choses, ni l'intérêt du capital, ni les profits du fonds de terre qui ont concouru à leur production' (Say 1819b, 1: 28-9). Again (in a Note on Ricardo 1951-73, 1: 385), Say complained that Ricardo maintained throughout his Principles 'que la quantité de travail nécessaire pour faire un produit, est le seul élément de son prix, et qui ne tient nul compte de ce que peut avoir coûté le concours du capital et du fonds de terre' (Say 1819b, 2: 297).

Say's error was to forget that Ricardo's labour theory is designed to explain relative price changes, and does not imply that full costs for each product excluded the return to capital. Ricardo was obliged to spell this out in 1821 in response to Malthus (above, p. 3). Apart from the rent issue to which we shall return, there is no difference between Say and Ricardo on the composition of costs.

$$
\text { * * * }
$$

It will be patently clear by now that Say's representation of the marketnatural price contrast as 'chimérique' (above, p. 30) is misleading on his own terms. Now Say in his Notes also represented the notion of 'absolute' or 'invariable' value as 'chimérique' and here too he misleads, as we shall explain.

The relevant Note is attached to Ricardo's proposition that 'we have no knowledge' of a commodity 'which at all times requires the same sacrifice of toil and labour to produce', though 'we may hypothetically argue and speak about it, as if we had; and may improve our knowledge of the science by shewing distinctly the absolute inapplicability of all the standards which have been hitherto adopted' (Ricardo 1951-73, 1: 275). Say's comment might be read to imply that there are only current prices with no central tendencies though it turns out as we shall see (below, p. 46) that this was not his intention:

La vérité est que la valeur des choses étant une qualité essentiellement variable d'un temps à un autre, d'un lieu à un autre, la valeur d'une chose (fût-ce celle du travail) ne peut servir de mesure à la valeur d'une autre chose, si ce n'est pour un temps et pour un lieu donné. C'est pour cela que, pour chaque lieu, il y a, tous les jours, un nouveau prix courant des marchandises, et un nouveau cours du change (qui n'est que le prix 
courant des diverses monnaies). Une mesure invariable des valeurs est une pure chimère, parce qu'on ne peut mesurer les valeurs que par des valeurs, c'est-à-dire par une quantité essentiellement variable. Il n'en résulte pas que la valeur soit chimérique; elle ne l'est pas plus que la chaleur des corps, qui ne peut pas se fixer davantage.

(Say 1819b, 1: 12-13)

La valeur est une qualité inhérente à certaines choses; mais c'est une qualité qui, bien que très réelle, est essentiellement variable, comme la chaleur. Il n'y a point de valeur absolue, de même qu'il n'y a point de chaleur absolue; mais on peut comparer la valeur d'une chose avec la valeur d'une autre, de même qu'on peut dire qu'une eau où l'on plonge le thermomètre, et qui le fait monter à quarante degrés, a autant de chaleur apparente que tout autre liquide qui fait monter le thermomètre au même degré. ... .

La valeur ne peut être mesurée que par la valeur. Si l'on entreprenait de mesurer la valeur des choses par une autre de leurs propriétés, ce serait comme si l'on voulait mesurer leur poids par leur forme ou par leur couleur; mais toute valeur étant essentiellement variable, aucune n'a la qualité nécessaire d'une mesure: l'invariabilité. Aucune ne peut donc servir à donner une idée exacte d'une autre valeur qui est dans un autre temps ou dans un autre lieu.

(Say 1819b, 2: 69-70)

Now on the denial of invariability itself, there is nothing that Ricardo would dispute. ${ }^{11}$ He himself pointed out that his 'gold' was selected as a measure on the suppositions (1) of constant labour productivity in mining, and (2) of the conditions required for the operation of a labour theory of exchange value both of which he realized were unrealistic (above, p. 3). But what strikes the reader forcefully is the fact that Say himself sought the best candidate as measure of value, selecting corn on the 'Malthusian' grounds laid down by Smith - that corn supply as it were 'creates its own demand' via the effect on population:

Dans un autre endroit de mon Économie politique, je donne les raisons qui me font croire que bien que la valeur d'aucune espèce de choses ne soit invariable, la valeur du blé est sur un grand nombre d'années communes la moins variable de toutes.

(Say 1819b, 2: 68) $)^{12}$

We illustrate from the Traité: 'Si la quantité de blé décuplait dans le monde, la demande du blé décuplerait aussi, parce qu'il naîtrait des hommes pour le manger; et le blé, relativement aux autres denrées, garderait, année commune, à peu près sa même valeur' (1814, 2: 21; 1817, 2: 27; 1819a, 2: 61); again: 'la cultivation de toute l'Amérique septentrionale ne ferait pas sensiblement baisser la valeur du blé en Europe; car alors l'Amérique se peuplerait 
de consommateurs en même temps qu'elle se couvrirait de moissons' (1814, 1: 362; 1817, 1: 357; 1819a, 1: 382; also 1826a, 2: 99). As for output reductions:

Les produits de l'industrie agricole ont même cela de particulier, qu'ils ne deviennent pas plus chers en devenant plus rares, parce que la population décroît toujours en même temps que les produits alimentaires diminuent; et que, par conséquent, la quantité de ces produits qui est demandée, diminue en même temps que la quantité offerte.

$$
\begin{array}{r}
\text { (1814, 2: 337n.; 1817, 2: 346n.; 1819a, } \\
\text { 2: 376n.; also 1826a, 3: 199n.) })^{13}
\end{array}
$$

Say does not even recognize a lagged relation between population growth and food supply; rather it expands 'en même temps'.

Ricardo cited this last passage in his Principles and objected: 'Has not M. Say forgotten ... that it is the cost of production which ultimately regulates price?' (1951-73, 1: 73n.). To this query, Say merely replied in the Notes: 'Je ne pense point que ce soient les frais de production qui définitivement règlent le prix des choses' (1819b, 1: 79) - a weak reply since (as we have shown at some length) Say did not reject the tendency of market to cost price, only (at times) the classical 'market-natural' terminology. In any event, in several conspicuous passages relative constancy of production costs enters as a further reason for the choice of corn as measure in addition to the population argument: 'Je n'en vois point en outre dont les frais de production doivent avoir aussi peu varié' (Say 1814, 1: 358; 1817, 1: 353; 1819a, 1: 378; also 1826a, 2: 94). Indeed, the historical constancy of corn production costs relative to the metals is much emphasized: 'Depuis la découverte des mines d'Amérique, l'argent étant tombé au quart environ de son ancienne valeur' - the context relates to 'une variation réelle par rapport à ses frais de production' - 'a perdu les trois quarts de sa valeur relativement à une marchandise, comme le blé qui n'a pas baissé de prix' (1814, 2: 42; 1817, 2: 49; 1819a, 2: 51). (Similarly in the last edition: 'le blé a toujours coûté à peu près les mêmes frais de production'; 1826a, 2: 196.) In all this, Say is rehearsing a familiar Smithian evaluation (Smith 1937 [1776]: 186-7).

We return to the justification for corn as measure in terms of the population mechanism. This mechanism was evidently of high importance to Say considering the number of times he returns to it in his Notes in defending Adam Smith. Thus the argument is spelled out in a rejection of Ricardo's insistence against Smith that corn be treated as a product like any other (in which context, incidentally, Ricardo also insists on the endogeneity of the margin):

Is it not . . subject to be enhanced in value from prohibition of importation, from increasing population and wealth, and the greater difficulty 
of obtaining the increased supplies, on account of the additional quantity of labour which the cultivation of inferior lands requires?

(Ricardo 1951-73, 1:15)

To this standard application of demand-supply analysis Say objects on grounds of its neglect of the hard-line population principle:

M. Ricardo ne tient nul compte de la raison qui a été donnée [by Smith] pourquoi la valeur du blé a dû être plus invariable que celle de toute autre marchandise.... Le blé est un produit qui, par sa présence, crée ses consommateurs, et qui par son absence les détruit. On n'en peut pas dire autant de l'or.

(Say 1819b, 1: 14)

He similarly draws on the population mechanism in disputing Ricardo's objection to the Smithian theme that the value of agricultural produce unlike that of the metals - is in proportion to their absolute, and not their relative fertility' (Ricardo 1951-73, 1: 330): 'Le motif qu'en donne Smith n'a rien qui répugne à ma raison. Partout où il peut crôitre des denrées alimentaires, il peut naître des hommes pour les consommer' (Say 1819b, 2: 186). He also adds that '[l]es démonstrations de Malthus, qui prouvent que la population tend toujours à surpasser les moyens de subsistances, confirment, ce me semble, la manière de voir de Smith'. Again, to the objection by Ricardo to Smith's proposition that 'corn is always of the same value because it will always feed the same number of people' - that it might equally be said 'that cloth is always of the same value because it will always make the same number of coats' (Ricardo 1951-73, 1: 374) - Say responded:

M. Ricardo oublie la raison que Smith en donne. La tendance qu'a la population à s'accroître au niveau des moyens de subsistance, multiplie l'espèce humaine partout où la production du blé augmente, et le travail humain, qui se multiplie en même temps, fournit le moyen de payer le blé.... De là, pour cette denrée, une demande toujours à peu près proportionnée à la quantité offerte.

(Say 1819b, 2: 271)

Say did add a defensive remark to the last formulation:

Je dis à peu près, car il n'y a rien de rigoureux en Economie politique, les besoins, les goûts, les passions, les craintes et les préjugés des hommes, exerçant une influence sur toutes les appréciations et n'étant point eux-mêmes des quantités rigoureusement appréciables.

But this cannot disguise the fact that, like Malthus, he approached a pricing problem in terms involving effectively interdependent supply and demand 
schedules, thereby undermining the market analysis of corn price. By contrast, Ricardo insisted on regular supply-demand analysis involving independent schedules with an eye on motivation. In a market economy as distinct from a centralized control system, so he insisted against Malthus's version of Sayian practice, expansion of food supplies turns, as with all products, on 'actual or expected demand' (above, p. 6).

It may be remarked in conclusion that Say at one point in his Notes appeals to the population effect to counter Ricardo's analysis of a tax imposed on corn - that a tax raises the corn price by generating output contraction upon the withdrawal of marginal land. Say's objection is that 'la production des substances alimentaires contrariée, entraîne la dépopulation', in brief that the demand schedule shifts back preventing any corn-price increase (Say 1819b, 2: 35).

Corn is a special case. 'Luxuries' are characterized by severe fluctuations of market price. Nonetheless, these occur about 'le prix naturel' or cost price:

La demande ... des superfluités ne s'élève pas à mesure que s'étendent les moyens de production de ces mêmes superfluités; si une vogue extraordinaire [1814, 1817: qui ne saurait jamais avoir lieu que dans une grande ville] en fait monter le prix courant fort au-dessus du prix naturel, c'est-à-dire du montant des frais de production, une vogue contraire le fait tomber fort au-dessous; les superfluités ne sont, pour les riches eux-mêmes, que d'un besoin secondaire, et la demande qu'on en fait est bornée par le petit nombre de gens à l'usage de qui elles sont.

(Say 1819a, 2: 83-4; also 1814, 2: 56-7;

1817, 2: 66-7; 1826a, 2: 249)

In the case of products other than corn Say thus applied standard 'classical' doctrine in the sense that there is said to exist some cost-based point of reference, though different disturbances will cause price fluctuations about it which are the more severe the less broadly based is the demand. Apart then from Say's Malthusian-based treatment of the corn price, there are no substantive disagreements between Say and Ricardo on cost pricing itself.

\section{The Notes (1819) on Ricardo's Principles: rent}

Say, we have seen, insisted against Ricardo on the inclusion of rent within costs. More specifically: '[d]ans les producteurs, je comprends toujours outre ceux qui fournissent le travail, ceux qui fournissent les fonds de terre et le capital, qui ne sont pas moins indispensables que le travail' (Say 1819b, 1: 79). Similarly:

Par services productifs j'entends l'action, le concours des travaux, des capitaux, des terres, dont il résulte un produit. Ceux qui fournissent leur travail, qui prêtent leur capital ou leur terrain, reçoivent le prix de ce concours, et ce prix compose les frais de production. 
During the course of a Physiocratic-flavoured panegyric upon land, Say traces out the consequences of failure to pay rent - the withdrawal of land with a consequential increase in food prices to assure the 'taux nécessaire' (1819b, 1: 83-4). ${ }^{14}$ And he applauded Smith's inclusion of rent within natural price, the market price assuring appropriate coverage:

ce loyer ferait partie des frais de production, de ce que Smith appelle le prix naturel du produit. Il entrerait aussi dans le prix vénal de ce même produit; car si l'acquéreur ne payait pas tout ce qu'il faut pour que la machine gagnât un loyer, cette machine, dont la volonté est représentée par la volonté de ses maîtres, cesserait de prêter son concours, et le produit n'aurait pas lieu.

Rather troublesome is Say's reaction in the following Note to Ricardo's conclusion that 'rent is not a component part of the price of commodities' (Ricardo 1951-73, 1: 78). For he seems uncertain regarding what falls within natural price: 'Entendons-nous. Si l'auteur veut dire que le profit foncier, le revenu du propriétaire, ne fait pas partie de ce que Smith appelle le prix naturel des choses, c'est-à-dire du montant des frais nécessaires de leur production, il peut avoir raison' (Say 1819b, 1: 94). But of course Ricardo had in mind the exclusion of rent from 'natural price'. And Say seems to allow that this might be justified. That this allowance must be taken very seriously indeed is confirmed by a further paragraph which insists only on the possibility of a corn price yielding rent even on the worst land, and this in the case of strict constraints on output:

les circonstances du pays peuvent être telles que les produits du sol, nécessairement bornés, soient toujours à un prix monopole qui assure aux propriétaires des plus mauvaises terres un profit foncier; que les capitaux ne peuvent pas être attirés vers ces produits, et les multiplier au-delà des bornes que leur opposent l'étendue du pays et la fertilité de son sol.

Now Ricardo himself had allowed for extreme cases of absolute output restraint where rent must be paid even on marginal output (above, p. 6). In any event, what we have here is a major concession by Say that marginal land might be rent free.

Moreover, in commenting on Ricardo's position that were landlords to relinquish rent, the price of corn - determined at the rentless margin would remain unchanged (Ricardo 1951-73, 1: 74-5), Say treats rent as a surplus not a cost, unlike profits which are paid at the uniform rate; his only reservation relates to the implication he found in Ricardo's formulation that private property as such yields no positive productivity advantages: 
La proportion entre l'offre et la demande fixe le prix des produits territoriaux comme de tout autre produit. Sur ces prix, l'industrie et les capitaux dont le concours a été nécessaire retirent des profits proportionnés aux risques, aux talens et au taux ordinaire des profits dans tout autre genre de production. Le surplus forme le revenu du propriétaire foncier, le profit annuel de son utile usurpation. [The productivity advantages flowing from private property.] En cela nous sommes d'accord avec M. Ricardo; mais lorsqu'il prétend que, n’y eût-il point de propriétaires, le prix du blé resterait le même, nous ne pouvons le croire.

This latter apologia does not touch on the analysis. ${ }^{15}$ But there is a further qualification that requires notice. Though Say treats rent here as a surplus over and above the costs of labour and capital, he insisted in some contexts on a minimum reservation price such that rent is paid on all land. This is the case in discussing the rent of mines:

Le propriétaire ... comme tout propriétaire foncier, exerce une espèce de monopole qui lui permet de soutenir la valeur de son produit au-delà des frais de main-d'œuvre et des intérêts de capitaux nécessaires pour le terminer et le mener sur le marché. Ce prix-monopole baisse par la concurrence, mais ne saurait, je crois, tomber à rien; car si le propriétaire des mines ne pouvait plus tirer aucun loyer de ses mines ... il ne les affermerait, ni ne les exploiterait; ce qui réduirait la quantité offerte de ce genre de produit, et le ferait monter jusqu'à ce qu'il offrît de nouveau un profit purement foncier et susceptible d'être affermé.

(Say 1819b, 1: 112)

Say recognized that the capital fixed in mines that have no alternative use might continue to be maintained though the return falls below the general level; such a case reduces in effect to that of land and Say allows that it supported Ricardo's perception of things. But even here he insists, 'il y a un profit foncier pour le propriétaire' if the mine remains in use:

Cependant il faut convenir, à l'appui de l'opinion de M. Ricardo, que les vastes capitaux engagés dans l'exploitation des mines sont un motif de les travailler même après qu'elles ne rapportent autre chose que l'intérêt de ces mêmes capitaux, même lorsqu'elles rapportent moins que l'intérêt de leurs capitaux; car des capitaux engagés à ce point, et qui ne peuvent se consacrer à aucun autre emploi sans perdre la majeure partie de leur valeur, contractent le désavantage du fonds: on continue à les faire travailler, quoiqu'ils rapportent moins que tout autre placement, afin de ne pas perdre même le peu qu'ils rapportent. Je les assimile complètement au fonds de terre ou à la mine; et je dis que, du moment 
qu'ils ne rapportent plus rien, on les abandonne; mais qu'aussi longtemps qu'ils rapportent quelque chose, il y a un profit foncier pour le propriétaire.

(Say 1819b, 1:112-13)

Similarly, in discussing Ricardo's position, based on zero-rent land, regarding taxes on land or agricultural products (Ricardo 1951-73, 1: 156), Say insists that all land pays rent 'quelque faible qu'il soit', because no landowner will agree to the free use of his land 'ne fût-ce que par mauvaise humeur' (Say 1819b, 1: 249). This position Say supported from 'experience' showing that in all populous and productive states 'les plus mauvaises terres, du moment qu'elles sont cultivées, rapportent toujours quelque fermage, et par conséquent quelque revenu foncier' (95). For example, '[o]n voit dans les montagnes des Alpes et du Jura une foule de mauvais pâturages sur lesquels il n'y a aucun capital répandu, qui tous rapportent un loyer à leurs propriétaires' (249).

Notwithstanding the qualification - it can easily be accommodated by adoption of continuity in place of the implicit discrete units - it remains true that Say, like Ricardo, distinguished rent from wages and profits. In any event, he at times allowed for no-rent lands, albeit of small empirical significance:

S'il y a quelques terres cultivées qui ne rapportent absolument rien à leur propriétaire pour son droit de propriété, elles sont en si petite quantité, que sur un grand pays elles exercent probablement peu d'influence sur la quantité et le prix des produits généraux.

Also indicative of substantive accord is Say's acceptance of Ricardo's position that rent is merely a transfer from the consumer:

On ne saurait disconvenir ... que le propriétaire foncier n'ajoute personnellement rien à l'utilité annuellement produite dans un pays. Si donc les circonstances du pays établissent, pour les produits agricoles, une demande telle que leur valeur vénale excède les autres avances, de manière à former un revenu pour le propriétaire foncier, il faut convenir que cet excédant est une portion de richesse tirée de la poche des consommateurs, pour être mise, sans équivalent de leur part, dans la poche des propriétaires fonciers.

(Say 1819b, 1: 91)

This accord is somewhat diluted when Say adds: 'On en peut dire autant du capitaliste qui fait valoir son capital.' And he changes the terms of reference when he goes on to the remark that since the private-property institution itself raised productivity, the landlord (and capitalist) may to some extent themselves be considered 'productive': 
Cependant s'il est impossible, comme il est prouvé dans mon Traité d'Économie politique (Liv.I), que la production ait lieu, non-seulement sans fonds de terre et sans capitaux, mais sans que ces moyens de production ne soient des propriétés, ne peut-on pas dire que leurs propriétaires exercent une fonction productive, puisque sans elle la production n'aurait pas lieu?

\section{Consider too his response to Ricardo's rhetorical question:}

Is it not, then, as certain, that it is the relative fertility of the land, which determines the portion of the produce, which shall be paid for the rent of the land, as it is that the relative fertility of mines, determines the portion of their produce, which shall be paid for the rent of the mines?

(Ricardo 1951-73, 1: 330)

Say's response is to accept Ricardo's position: 'Qui songe à nier cela, puisque le fermage est le prix annuel du pouvoir productif de la nature, toutes les fois que ce pouvoir est devenu une propriété?' (Say 1819b, 2: 187). His reservations alter nothing:

S'il arrive même, dans certains cas, que ce pouvoir ne soit pas payé, cela empêche-t-il qu'il le soit dans d'autres cas? Cela prouve-t-il que les produits du sol ne seront pas moins chers si ce pouvoir productif n'était payé dans aucun cas?

And it is also the case that we find him accepting Ricardo's position that a price rise would follow the imposition of a tax, provided (Say insisted) that it brought about a withdrawal of land from cultivation:

Il faudrait qu'un nouvel impôt sur les produits des terres fût considérable au point de faire abandonner des terres actuellement en culture, pour qu'il fit augmenter le prix des blés. Si un tel impôt n'augmente pas sensiblement l'étendue des terrains en friche, on ne voit pas pourquoi le prix des blés augmenterait, puisque l'approvisionnement serait le même.

$$
(1: 250)^{16}
$$

There is more pointing to Say's 'classical' stance. We commenced this section by indicating passages which perceive rent as a cost of production; these imply alternative opportunities in the case of land as well as capital and labour. However, in some contexts Say allows a degree of immobility peculiar to the land factor: 'Je conviens que ce profit du propriétaire foncier supporte, plus que les profits du capital et de l'industrie, les inconvéniens du local; car une certaine portion du capital et les travaux ne sont pas aussi 
immobiles que la terre' (Say 1819b, 1: 84). For this reason, one finds that 'certaines terres ne rapportent que 20 sous l'arpent à leur propriétaire, tandis que d'autres se louent 100 frs., 200 frs., et davantage'. And there is also the sharp contrast between the mobility of capital and of land encountered in the context of taxation (Say 1819b, 2: 32-3, discussed above, p. 40).

I turn now to Say's reaction to criticism by Ricardo of Buchanan for whom the corn price 'always yields a rent', so that a tax on corn falls on rent not the consumer (Ricardo 1951-73, 1: 251-2). For Ricardo, until the extreme limiting case of a maximum corn supply, the corn price is determined at the no-rent margin since 'there is always a portion of capital employed on the land which yields no rent, and ... it is this portion of capital, the result of which, as in manufactures, is divided between profits and wages that regulates the price of corn', so that the consequence of a tax is a higher price not a lower rent (252). Ricardo then cites Buchanan to the contrary: 'Manufacturing industry increases its produce in proportion to the demand, and the price falls; but the produce of land cannot be so increased; and a high price is still necessary to prevent the consumption from exceeding the demand' (Buchanan [1814] 4: 40). 'Is it possible', Ricardo objected, 'that Mr. Buchanan can seriously assert, that the produce of the land cannot be increased, if the demand increases?' (252n.).

At this point in his Notes Say attempts to justify Buchanan by reference to Malthus's population principle in an even stronger version than that used to support corn as measure of value (above, p. 43), asserting that rent is assured because demand for corn is always sufficiently high relative to a supply limited by land scarcity. Rent emerges in all this as a simple scarcity payment - a 'monopoly' return, or surplus, and not a cost of production:

M. Buchanan suppose, je pense, que la tendance qu'a la population à devancer les moyens de subsistance (Voyez les raisons irrésistibles qu'en donne Malthus), établit une demande telle que le prix des substances excède toujours ce qui serait rigoureusement nécessaire pour payer les seuls profits du capital et de l'industrie employés à la culture des terres. ... [L $]$ a demande n'étant jamais bornée, et l'offre l'étant toujours (puisque l'étendue des terres cultivables l'est), le produit des terres doit être à un prix monopole, qui s'élève d'autant plus que les facultés des consommateurs s'augmentent.

(Say 1819b, 2: 23-4)

Say intends a positive rent on all land in cultivation. Hitting upon the notion of discrete intervals, he adds that the mere existence of uncultivated land does not prove otherwise since costs might be too high on these lands to be relevant locally (24).

After all this, it comes as a surprise to find Say allowing that should demand pressure prove inadequate, then rent on land in cultivation might with one qualification - be eradicated: 
Si la concurrence des producteurs fait baisser ce prix au niveau des frais de production, ce n'est pas une raison pour que les propriétaires des terres réduisent leurs prétentions au niveau de rien; car, quoique les fonds de terre n'aient rien coûté dans l'origine, l'offre de leur concours est nécessairement borné, et les bornes de la quantité offerte sont aussi l'un des élémens de la valeur.

To insist that rent cannot fall literally to zero is a formality, taking us back to the earlier remark regarding la 'mauvaise humeur' of the landowner (above, p. 49). Say admits the substance of the canonical case, at least with respect to the extensive margin.

As for Ricardo, we recall from Chapter 1 that he readily allowed the 'monopoly' interpretation in the event of a maximum corn output. But this extreme case was highly unlikely and he relied on the possibility of defining a positive marginal product to capital applied to land as the prime basis of his rent doctrine; the general principle of a no-rent margin applied where only the more intensive use of given land is involved: 'rent is always the difference between the produce obtained by the employment of two equal quantities of capital and labour' (Ricardo 1951-73, 1: 71). Again, whether 'there were no lands remaining which did not afford a rent' was irrelevant: 'it is the same thing if there be any capital employed in Great Britain on land, which yields only the return of stock with its ordinary profits, whether it be employed on old or on new lands' (328). In correspondence of December 1818 with James Mill, Ricardo expressed his disappointment that Malthus proposed to adopt, in his forthcoming Principles, the same position as Say regarding the alleged empirical significance of the non-existence of no-rent land:

He has altered his position . . . about there being land in every country which pays no rent, and appears like M Say to think that when that is proved, my doctrine of rent not entering into price is overthrown they neither of them advert to the other principle which cannot be touched, of capital being employed on land, already in cultivation, which pays no rent.

(Ricardo 1951-73, 7:372)

Sismondi (1819) made the same error: 'He as well as Say attempts to refute the doctrine of rent, because there is no land they say which does not pay rent' (to Mill, 6 September 1819; Ricardo 1951-73, 8: 57). And to Say himself he wrote after reading the Notes that '[y]ou appear to me to have mistaken ... an opinion of mine on which you comment in a note of the translation of my book'; that his opinion was

founded on a supposition that there is land in every country which pays no rent, or that there is capital employed on land before in cultivation 
for which no rent is paid. You answer the first position, but you take no notice of the second. The admission of either will answer my purpose.

(11 January 1820: 149-50)

In the revisions to his Principles for the second (1819) and third (1821) editions he wrote with some annoyance:

M. Say, in his notes to the French translation of this work has endeavoured to shew that there is not at any time land in cultivation which does not pay a rent, and having satisfied himself on this point, he concludes that he has overturned all the conclusions which result from that doctrine. He infers, for example, that I am not correct in saying that taxes on corn, and other raw produce, by elevating their price, fall on the consumer, and do not fall on rent. He contends that such taxes must fall on rent. [1819: He infers, for example, that I am not correct in saying that taxes on raw produce do not fall on rent, but by elevating the price of raw produce they fall on the consumer. He contends that they do fall on rent.] But before M. Say can establish the correctness of this inference, he must also shew that there is not any capital employed on the land for which no rent is paid (see the beginning of this note, and pages 67 and 74 of the present work); now this he has not attempted to do. In no part of his notes has he refuted, or even noticed that important doctrine. By his note to page 182 of the second volume of the French edition, he does not appear to be aware that it has even been advanced.

(Ricardo 1951-73, 1: 413n.)

Ricardo was justifiably vexed. At no time did Say take the intensive margin seriously. But the fact remains that in the 1819 Notes he did adopt a (slightly qualified) notion of zero rent at the extensive margin, and this alone is significant indeed.

$$
\text { * * * }
$$

Say's perception of rent as a surplus income due to land scarcity was recognized by Malthus and heartily rejected because it clashed with the categorization of agriculture as a peculiarly productive sector. Malthus maintained this latter position in the Principles, where it is directed against Ricardo:

It seems rather extraordinary that the very great benefit which society derives from that surplus produce of the land which, in the progress of society, falls mainly to the landlord in the shape of rent, should not yet be fully understood and acknowledged. I have called this surplus a bountiful gift of Providence, and am most decidedly of opinion, that it fully deserves the appellation.

(Malthus 1820: 226) 


\section{Value, distribution and growth before 1823}

But he objected on just these grounds to Say's contrast, as expressed in the Traité, between free natural agents and scarce land (relative to demand), the latter envisaged as the source of land rent: 'Heureusement personne n'a pu dire, le vent et le soleil m'appartiennent, et le service qu'ils rendent doit m'être payé' (Say 1814, 2: 124). And though Say 'acknowledges that, for obvious reasons, property in land is necessary, yet he evidently considers rent as almost exclusively owing to such appropriation and the external demand' (Malthus 1820: 136). ${ }^{17}$

Ricardo entered the fray in his Notes on Malthus's Principles:

I repeat confidently that rent is owing to the limit which nature has set to her present, and not to the unbounded extent of it. If there had been no limits to fertility, if one capital after another had been equally productive of produce, no rent could have been generated,

(Ricardo 1951-73, 2: 211)

And in these terms he defended Say: 'Can any one doubt that if a person could appropriate to himself the wind and the sun, he would be able to command a rent for the uses to be derived from them?' (104). Needless to say, Ricardian rent doctrine reflects land scarcity and it comes as no surprise that he should see eye to eye with Say on this matter of principle.

Say, we have seen, did not admit frankly the extent of common ground. He was, as it were, forced to admit the possibility of zero (or near-zero) rent. And he certainly did not modify the Notes systematically in line with his revised position. Conspicuous here is his defence of Smith on the effect of corn taxes on rent rather than the corn price:

M. Ricardo [1951-73, 1: 184] part toujours du principe qu'on est loin de lui accorder, que l'impôt sur les premiers produits, et que l'impôt en nature, comme la dîme, ne tombent pas sur le propriétaire foncier, mais bien sur le consommateur. . . Smith a justement établi que l'impôt sur les terres ... n'en fait pas hausser le prix et, par conséquent n'est pas payé par le consommateur.

(Say 1819b, 1: 305-6)

This leads us to the further complexity that Say, without apparently recognizing his inconsistency, actually shared with Malthus and Smith the Physiocratic notion of agriculture as most productive sector on grounds of its generation of a rent income, a third income unavailable in manufacturing. Ricardo in his Principles cited in translation the Traité to the effect that 'the natural course of things draws capital, not to those employments where the greatest profits are made, but to those where their operation is most profitable to the community' (Say 1814, 2: 122); and he complained: 
M. Say has not told us what those employments are, which, while they are the most profitable to the individual, are not the most profitable to the State. If countries with limited capitals, but with abundance of fertile land, do not early engage in foreign trade, the reason is, because it is less profitable to individuals, and therefore also less profitable to the State.

(Ricardo 1951-73, 1: 349-50n.)

Responding to this challenge in a Note, Say refers to the superiority of agriculture on the grounds that an additional rental income is generated apart from the return to capital:

Les emplois de capitaux qui, tout en procurant un profit au propriétaire du capital, mettent en valeur les facultés industrielles des gens du pays, ou les facultés productives du sol, augmentent plus les revenus du pays que les emplois qui ne procurent d'autre revenu que le simple profit du capital.

(Say 1819b, 2: 226)

But this response is undermined by the allowance for zero-rent land. As for Ricardo's proposition that rent would have to be covered in manufacturing prices should the natural forces required in that sector become scarce (and subject to private ownership) (see p. 11), Say gives a poorly-conceived reply:

Oui, mais l'appropriation exclusive dans les arts n'étant point indispensable pour que le produit existe, on se passerait de celui qui voudrait faire payer la pesanteur de l'atmosphère ou la chaleur du soleil. La quantité offerte des produits des arts n'en étant pas moindre, leur prix ne monterait jamais au point de fournir un profit à ce propriétaire imaginaire.

(Say 1819b, 1: 90)

\section{Modifications to the Traité $1819^{18}$}

A footnote introduced into the fourth (1819) edition of the Traité purports to teach Ricardo a lesson regarding the demand-determined margin in the context of the cost of the precious metals, insisting on the extensions to and withdrawals of marginal mines upon variation in demand:

M. Ricardo, et quelques autres, soutiennent que les seuls frais d'extraction déterminent le prix des métaux, c'est-à-dire la quantité plus ou moins grande qu'on en offre en échange de toute autre chose. Ils établissent, par conséquent, que le besoin qu'on en a n'y influe en rien. C'est contredire la mieux constatée de toutes les expériences; celle qui nous montre chaque jour que la valeur des choses s'accroît par la demande. . . . 
La demande de l'or augmentant, il deviendrait plus précieux qu'il n'est; on chercherait à exploiter des mines d'or qu'on n'exploite pas en ce moment, parce que leur produit n'indemnise pas des frais d'extraction. Les frais d'extraction deviendraient plus considérables; mais pourrait-on nier cependant que l'augmentation de valeur ne fût due à l'augmentation de la demande? Le besoin qu'on éprouverait de cette marchandise ferait que l'on consentirait à payer de plus gros frais de production.

(Say 1819a, 1: 336n.)

Suivant M. Ricardo, la demande supérieure n'a eu aucun effet sur la valeur de l'argent, qui n'est déterminée que par ses frais de production; il ne fait pas attention que c'est la demande qu'on en fait qui permet de mettre ce prix à ses services productifs. Si la demande du métal argent venait à diminuer, son prix ne payant plus les frais de production de certaines mines, elles cesseraient d'être exploitées.

(Say 1819a, 2: 59n.)

Despite his insistence to the contrary, Say is expounding here pure Ricardian doctrine.

A further complaint of 1819 - removed in 1826 - is that Ricardo (Say also mentions Destutt de Tracy) reduced value to labour embodied alone excluding rent:

Plusieurs publicistes sont d'avis que la valeur des produits ne paie jamais que le travail nécessaire pour les produire, et que, par conséquent, aucune portion de leur valeur ne reste pour former le profit du fonds de terre, d'où naît le fermage payé par le fermier au propriétaire du sol.

Yet we find that Say goes on in his text to recognize zero-rent land and at least to imply the existence of differentials:

On voit en Écosse de mauvais terrains ainsi cultivés par leurs propriétaires, et qui ne pourraient l'être par aucun autre. C'est ainsi encore que nous voyons dans les provinces reculées des États-Unis, des terres vastes et fertiles dont le revenu tout seul ne suffirait pas pour nourrir leur propriétaire; elles sont cultivées néanmoins, mais il faut que le propriétaire les cultive lui-même, c'est-à-dire, qu'il porte le consommateur à l'endroit du produit, et qu'il ajoute au profit de son fonds de terre, qui est peu de chose ou rien, les profits de ses capitaux et de son industrie qui le font vivre dans l'aisance.

(Say 1819a, 2: 168-9)

This last allowance provides an instance of silent adberence to Ricardo's position, in line with what we have found to be the case in the Notes. More 
generally, the 1819 edition of the Traité suggests that Say was indeed coming ever closer, he himself writing to Ricardo on 10 October 1819 in such obsequious terms that one feels embarrassed for the author - of modifications in the new edition due to, perhaps in the sense of stimulated by, Ricardo:

Permettez-moi, Monsieur, de vous offrir un exemplaire de la $4^{\text {ème }}$ édition de mon Traité d'Economie politique qui vient de paraître. Vous verrez par les corrections que j'ai faites, notamment dans les premiers chapitres du Livre $2^{\text {ème }}$ sur la Distribution des richesses, combien vos critiques m'ont été utiles, puisqu'elles m'ont obligé à remettre sur le métier les parties les plus délicates de ma doctrine. Je m'estimerai bien heureux si ces corrections et quelques autres parviennent à vous ramener sur les points peu nombreux où $j$ 'ai eu le malheur de ne pas me rencontrer avec vous. J'espère que dans les occasions rares où je me suis permis de vous combattre, vous ne trouverez pas que je me sois écarté des égards que l'on doit à vos excellentes intentions et à vos vastes lumières. ${ }^{19}$

(Say, in Ricardo 1951-73, 8: 136)

Now the English translator of the fourth edition, C. R. Prinsep, points to a remodelling of the first three chapters of the second book appearing in the earlier editions and their condensation into two chapters with a particular focus on the cost determination of relative price:

The grand variation is, the admission of difficulty of attainment, to be a constituent part, if not the sole regulator of relative value. ... In former editions, utility was laid down as the basis; and so it still seems to be, in Book 1, with regard to positive value.

(Prinsep, in Say 1821 [1819a]: 1-2n.)

As for Say himself, he writes in his 1819 Avertissement: 'Les cinq premiers chapitres du Liv II, ont été refaits presque entièrement, et présentent une théorie complète des valeurs et de leur distribution dans la société sous la forme de revenus' (Say 1819a, 1: vii). But though the first chapter of Book II now emphasises the demand-supply determination of 'current prices' both of goods and services, we still find the assumption of factor mobility assuring a tendency to uniformity of return between uses. Thus, after a numerical example, Say traces out the consequences of higher earnings made available in some other industry: 'Une partie d'entre eux se retirerait de la première de ces fabrications en faveur des autres, jusqu'à ce qu'ils fussent demandés et payés autant que tout autre service analogue' (Say 1819a, 2: 8-9). This, of course, implies the canonical tendency of market to cost price. And the cost dimension emerges quite explicitly: 'Il se peut que l'utilité d'une chose, c'està-dire, le besoin qu'on en a, ne puisse pas en élever le prix au taux où le porteraient ses frais de production. Alors la chose n'est point produite. Elle coûterait plus qu'elle ne vaudrait' (17). ${ }^{20}$ In this light, I find the following formal objection to Ricardo in the same chapter difficult to appreciate: 
C'est, comme on voit, la valeur d'une multitude de produits balancés entre eux, qui fonde la valeur courante des services productifs, et ce n'est pas la valeur des services productifs qui fonde la valeur des produits, ainsi que l'ont avancé quelques auteurs [Ricardo, Principles, ch. 30]; et comme c'est l'utilité du produit qui le fait rechercher, qui lui établit une valeur, c'est la faculté de pouvoir créer cette utilité qui fait rechercher les services productifs, qui leur établit une valeur; valeur qui équivaut pour chacun d'eux à l'importance de sa coopération, et dont le total forme, pour chaque produit, ce qu'on appelle ses frais de production.

(Say 1819a, 2: 9-10)

This passage is, however, removed in 1826.

A discussion of the absolute prohibition of certain imports introduced in 1819 further confirms agreement with Ricardo on the 'natural-price' issue, in terms almost identical with those we encountered in the Notes (above, p. 41) when Say admitted his error in having contended that protection raises the profit rate (Say 1819a, 1: 209-10n.; 1826a, 1: 249-50n.).

$$
\text { * * * }
$$

Ricardo himself in his own third edition of 1821 cites approvingly Say's recognition of the cost principle in the Epitome at the end of the second volume of the 1819 Traité. The second and third extracts below relate to the very 'doctrine of services' that Say himself claimed particularly distinguished his own work:

There is no real dearness but that which arises from the cost of production. A thing really dear, is that which costs much in producing.

(Ricardo's translation from Say 1819a, 2: 457)

In the exchange of two products, we only in fact exchange the productive services which have served to create them.... The value of all the productive services that must be consumed to create a product, constitute the cost of production of that product.

(Ricardo's translation from Say 1819a, 2: 504-5)

It is utility which determines the demand for a commodity, but it is the cost of its production which limits the extent of its demand. When its utility does not elevate its value to the level of the cost of production, the thing is not worth what it cost; it is a proof that the productive services might be employed to create a commodity of a superior value. The possessors of productive funds, that is to say, those who have the disposal of labour, of capital or land, are perpetually occupied in comparing the cost of production with the value of the things produced, or which comes to the same thing, in comparing the value of different 
commodities with each other; because the cost of production is nothing else but the value of productive services, consumed in forming a production; and the value of a productive service is nothing else than the value of the commodity, which is the result. The value of a commodity, the value of a productive service, the value of the cost of production are all, then, similar values when every thing is left to its natural course.

(Ricardo's translation from Say 1819a, 2: 507-8)

(Ricardo 1951-73, 1: 282-3)

Now with one qualification Ricardo approved: 'M. Say maintains with scarcely any variation, the doctrine which I hold concerning value. In his productive services, he includes the services rendered by land, capital, and labour; in mine, I include only capital and labour, and wholly exclude land' $(283-4) .{ }^{21}$ Rent was to be considered

as the result of a partial monopoly, never really regulating price, but rather as the effect of it. .. [T] commodities produced on land, for which no rent is or can be paid, as the surplus produce is only sufficient to pay the profits of stock.

Ricardo mentioned to Malthus that he was favourably disposed towards Say's 'doctrine of services' except for the treatment of rent on a par with profits and wages: 'I think more may be said in defence of his doctrine of services - they are I think the regulators of value, and if he would give up rent, he and I should not differ very materially on that subject' (9 October 1820; Ricardo 1951-73, 8: 277). ${ }^{22}$ And Malthus himself seems to have taken the same view, perceiving any difference as terminological, as in the following comment:

the natural conditions of the supply of muslins which were to purchase the ounce of gold were lowered. To use the language of M. Say, the productive services required to obtain gold in England were diminished, and the value of gold naturally fell.

(Malthus 1986 [1823], 7: 250)

Before proceeding to Say's reaction it will be best if we return the three extracts that have preoccupied us to their context in the original, better to identify variations between the fourth edition of 1819 and the third of 1817 (and in Chapter 3 between the 1819 and the 1826 editions).

The full passage from which the first of the extracts is taken runs as follows in the original under the heading 'CHERTÉ, BON MARCHÉ':

La cherté est la haute valeur, le bon marché la basse valeur des choses. Mais comme la valeur des choses est relative, et qu'elle n'est haute ou basse que par comparaison, il n'y a de cherté réelle que celle qui provient des frais 
de production. Une chose réellement chère est celle qui coûte beaucoup de frais de production; qui exige la consommation de beaucoup de services productifs. Il faut entendre le contraire d'une chose qui est à bon marché.

Ce principe ruine la fausse maxime: quand tout est cher, rien n'est cher; car pour créer quelque produit que ce soit, il peut falloir, dans un certain ordre de choses, faire plus de frais de production [1817: frais] que dans un autre ordre. C'est le cas où se trouve une société peu avancée dans les arts industriels, ou surchargée d'impôts. Les impôts sont des frais qui n'ajoutent rien au mérite des produits. Les progrès dans les arts industriels sont, soit un plus grand degré d'utilité [1817: de mérite] obtenu pour les mêmes frais, soit un même degré d'utilité [1817: de mérite] obtenu à moins de frais. ${ }^{23}$

(Say 1817, 2: 431-2; 1819a, 2: 457)

There are no significant differences here between 1819 and 1817 on the cost basis of 'real' value.

The second passage in the original from which Ricardo's extract is taken reads thus, under the heading 'SERVICES PRODUCTIFS':

Dans l'échange qu'on fait de deux produits, on n'échange dans le fait que les services productifs qui ont servi à les créer. Dans cet échange chacun cherche à donner le moins de services productifs qu'il peut et à en recevoir davantage; c'est-à-dire, offre le produit qui en a exigé le moins, contre celui qui en a exigé le plus; ce qui dirige les services productifs vers les genres de production où il y a le moins de frais de production à faire.

La valeur de tous les services productifs qu'il faut consommer pour former un produit, compose les frais de production de ce produit.

(Say 1819a, 2: 504-5)

Now the paragraph of the 1819 version commencing 'Dans l'échange' replaces two paragraphs in 1817 , the second of which focuses explicitly on uniformity of return assured by appropriate commodity-supply adjustments:

La valeur des services productifs se règle suivant les principes qui déterminent la valeur de toutes les autres choses; c'est-à-dire que leur valeur s'élève en raison directe de la quantité de services demandée, et en raison inverse de la quantité de services offerte.

Les prix des services productifs (toutes choses d'ailleurs égales) s'égalisent entre eux, quel que soit le produit auquel ils concourent. Car si les services productifs appliqués à certain produit, étaient mieux payés que ceux qui sont appliqués à certain autre, on dirigerait plus de facultés productives vers le premier; il y aurait une plus grande quantité de ce produit dans la circulation: son prix baisserait jusqu'à ce que les services productifs nécessaires à son existence ne fussent pas mieux récompensés que dans tout autre emploi.

(Say 1817, 2: 481-2) 
It is not clear why Say deleted this emphasis on factor mobility in $1819 .^{24}$ It would certainly have to be weighed in the balance as indicating a retreat from Ricardian costs were it not that the third of the cited passages from the 1819 version expounds the factor-mobility principle at considerable length and in striking terms. For that passage asserts (in Ricardo's translation) that if demand for a product 'does not elevate its value' - evidently market value - 'to the level of the cost of production . . . it is a proof that the productive services might be employed to create a commodity of a superior value'; while those having 'the disposal of labour, of capital or land, are perpetually occupied in comparing the cost of production with the value of the things produced' (above, p. 58). It is implied here that the adjustments in the case of deviations between market values and costs - the transfers of resource services from lower to higher yielding sectors - raise the average level of returns.

Compared with the 1817 version that of 1819 in fact provides a significant elaboration, rather than a weakening, of the principle at hand. To see this, consider the original in full context:

VALEUR DES CHOSES, valeur échangeable, valeur appréciative des choses. C'est ce qu'une chose vaut; c'est la quantité d'autres choses évaluables qu'on peut obtenir en échange d'elle. La valeur de chaque chose est le résultat de l'évaluation contradictoire faite entre celui qui en a besoin ou qui la demande; et celui qui la produit, ou qui l'offre. Ses deux fondemens sont donc: 1. L'utilité qui détermine la demande qu'on en fait. 2. Les frais de sa production qui bornent l'étendue de sa demande.

Lorsque son utilité n'élève pas sa valeur au niveau de ses frais de production, la chose ne vaut pas ce qu'elle coûte; c'est une preuve que les services productifs pouvaient être employés pour créer une valeur supérieure à la sienne. Les possesseurs de fonds productifs, c'est-à-dire ceux qui disposent de quelques facultés industrielles, de quelques capitaux ou fonds de terre, sont en conséquence perpétuellement occupés à comparer les frais de production avec les valeurs produites, ou (ce qui revient au même) à comparer entre elles les valeurs produites; car les frais de production ne sont autre chose que la valeur des services productifs, consommés pour donner un produit; et la valeur d'un service productif n'est autre que la valeur du produit qui en sort. Valeur du produit, valeur du service productif, valeur des frais de production, sont donc des valeurs pareilles toutes les fois que les choses sont abandonnées à leur cours naturel. Or, c'est la valeur uniforme de toutes ces choses qui se règle d'après l'offre et la demande, d'après la quantité qu'on peut fournir d'un certain produit, et d'après le besoin qu'on en a. Ce qui, toutes les fois que la liberté existe, dirige toujours la production du côté des choses dont le besoin se fait le plus sentir.

(Say 1819a, 2: 507-8)

By contrast, in the 1817 edition, following the 'deux fondemens', we have only a rather bland formulation: 
La valeur des choses appréciée en monnaie est ce qu'on nomme leur prix. La richesse se compose de la valeur des choses qu'on possède. Pour les trois sortes de variations qui peuvent survenir dans la valeur des choses, voyez le mot prix.

(Say 1817, 2: 485; also 1814, 2: 478)

The reference just given to 'PRIX' in the Epitome to the 1814 and 1817 editions is substantive because of its insistence on the constant tendency of market to natural price:

Le prix courant est le prix auquel les choses se vendent couramment dans chaque lieu. Il s'établit par le débat contradictoire qui s'élève entre ceux qui ont besoin de vendre, et ceux qui ont besoin d'acheter. Il est toujours relatif, mais tend constamment à se rapprocher du [1814: se rencontrer avec le] prix naturel.

(Say 1817, 2: 464-5; also 1814, 2: 463-4)

Now the 1819 version of the entry is reworked to identify costs with the return to productive services and to avoid the expression natural prices, but these modifications leave untouched the substantive proposition regarding the tendency of market to cost prices:

Le prix courant de tous les produits, en raison de la libre concurrence, tend perpétuellement à se rapprocher du prix courant de leurs services productifs; c'est-à-dire à se rapprocher de leurs frais de production, de leurs PRIX NATURel, selon l'expression d'Adam Smith. [Note: Cette démomination de PRIX NATUREL paraît superflue. Le prix courant des services productifs n'a rien de plus naturel que le prix courant des produits.]

(Say 1819a, 2: 486) ${ }^{25}$

It is thus clear from the summaries of his position appearing in the Epitome in 1819, and remarked on favourably by Ricardo in 1821, that Say did not water down his position on cost price between 1817 and 1819 . There was no weakening even regarding the process whereby long-run equilibrium prices are achieved. On the contrary, Prinsep was right in perceiving a stronger cost orientation in the revised edition (above, p. 57).

Reference to other key entries reinforces our conclusion. An addition under PRODUCTION, PRODUIRE appearing in 1819 (below, pp. 201-2) certainly does imply factor mobility and a tendency to uniformity of return (Say 1819a, 2: 489). The entry under the same heading in 1817 does not elaborate the adjustment mechanism (1817, 2: 465; also 1814, 2: 465).

A second instance is provided by the entry under SPECULATEUR, SPECULATION: 
Le commerce de spéculation consiste plutôt à acheter une marchandise lorsqu'elle est à bon marché, pour la revendre lorsqu'elle est chère, qu'à l'acheter au lieu où elle vaut moins pour la revendre au lieu où elle vaut plus. Cette dernière opération constitue le commerce proprement dit; elle donne une véritable façon aux produits, leur communique, en les mettant à portée du consommateur, une qualité qu'ils n'avaient pas. Le spéculateur n'est d'aucune utilité, si ce n'est pourtant de retirer une marchandise de la circulation lorsqu'elle y est trop abondante, pour l'y reverser lorsqu'elle y est trop rare. [Note: Elle y est trop abondante lorsque l'avilissement de son prix nuit à sa production; elle y est trop rare lorsque les besoins de la consommation la font payer par le consommateur à un prix qui surpasse ses frais de production.]

(Say 1819a, 2: 505)

The 1817 version (and that of 1814) is identical with that of 1819 except for the close of the note: 'elle y est trop rare lorsque les besoins de la consommation la font payer par le consommateur au-delà de son prix naturel, c'est-à-dire, au-delà de ses frais de production' (1817, 2: 483n.; also 1814, 2: 476n.). But to omit in 1819 the term 'prix naturel' as synonym for 'frais de production' is scarcely substantive; as we have already pointed out, Say wished merely to avoid some of the standard expressions.

Say's formal objection to the market-natural-price contrast is repeated at about this time in the Lettres à M. Malthus:

the price of every thing being its exchangeable value estimated in money ... there is no other price in political economy than market price. . . [T] [That which Smith calls the natural price, is no more natural than any other; it is the cost of production; it is the market price of productive services.

(Say 1821 [1820]: 78)

But the orthodox market-natural distinction reflects the contrast between disequilibrium and equilibrium allocations of resources across industries. And Say's concern is precisely with equilibrium in the sense of resources satisfying the condition that a transfer elsewhere will not raise their net income. For example, in discussing the profits of the 'undertaker' - 'the reward of the labour and talents which he exerts in his business' - Say writes: 'He only continues this business while it produces such an income that he cannot expect a better in any other employment. He is one of the necessary producers, and his profits form part of the necessary charges of production' (34n.). Say is dealing with 'natural' or 'necessary' price whatever he calls it. His belief to the contrary reflects in part overenthusiasm for the doctrine relating to the earnings of 'productive services', since it is true enough that the excessive (or deficient) earnings of some or all of the productive services characterizing deviation of market from natural price can be formally represented as high (or low) 'cost', if by cost we mean simply actual rather than equilibrium earnings. 


\section{A further modification: the falling rate of interest and the inverse profit-wage relation}

Say appealed frequently in the Traité to Smithian 'increasing competition of capitals' to explain the falling profit rate. Now as Ricardo pointed out in the Principles, this perception of things conflicted with the Law of Markets:

Is the following quite consistent with M. Say's principle? 'The more disposable capitals are abundant in proportion to the extent of employment for them, the more will the rate of interest on loans of capital fall' [Traité 1814, 2, 108]. If capital to any extent can be employed by a country, how can it be said to be abundant, compared with the extent of employment for it?

(Ricardo 1951-73, 1: 290n.)

Since this objection is made in all editions of the Principles, it appears that Ricardo was unaware of a concession by Say in one of his Notes of 1819 that it is indeed the increasing cost of wage goods that depresses the profit rate via the increase in the (money) wage - the inverse wage-profit relation as it applies to the growth process - or, in Ricardo's own words, that

[t]here cannot ... be accumulated in a country any amount of capital which cannot be employed productively, until wages rise so high in consequence of the rise of necessaries, and so little consequently remains for the profits of stock, that the motive for accumulation ceases.

The letter to Say of 8 May 1821 also suggests that he was unaware of any change on Say's part:

Allow me also to remark that your work would be much more valuable if you entered more fully into the laws which regulate rent and profit. It certainly was a great mistake of Adam Smith to suppose that profits depended on the degree of accumulation of capital, without reference to the question of population, and the means of providing for that population.

(Ricardo 1951-73, 8: 380)

We turn now to the Note in question:

M. Ricardo tire ici une conséquence parfaitement juste du principe établi dans mon Traité d'économie politique, et il explique d'une manière qui me paraît très-satisfaisante la baisse des profits-capitaux, ou intérêts, à mesure que les capitaux s'accroissent, quoique les emplois se multiplient avec les capitaux. Il est également certain que j'ai eu tort de dire que les capitaux peuvent 
être plus ou moins abondans par rapport à l'étendue des emplois, ayant prouvé ailleurs que les emplois se multiplient en proportion de l'abondance des capitaux.

(Say 1819b, 2: 107; emphasis added)

Unfortunately, Say did not in this particular case (though perhaps the printer was at fault) number his Note to indicate precisely its intended location. It is printed immediately after Ricardo's footnote cited above charging him with inconsistency, and this would suggest that 'the principle' in the opening declaration - 'M. Ricardo tire ici une conséquence parfaitement juste du principe établi dans mon Traité' - refers to the Law of Markets (as a secular proposition). Against this, however, must be set the fact that the second sentence of the Note constitutes a mea culpa with respect to this very charge, suggesting that the first refers not to the Ricardo footnote just mentioned but to one immediately preceding, interpreting the low interest rate in Holland in canonical terms in place of Smithian competition of capitals:

Adam Smith speaks of Holland, as affording an instance of the fall of profits from the accumulation of capital, and from every employment being consequently overcharged. 'The Government there borrow at 2 per cent., and private people of good credit, at 3 per cent.' But it should be remembered, that Holland was obliged to import almost all the corn which she consumed, and by imposing heavy taxes on the necessaries of the labourer, she further raised the wages of labour. These facts will sufficiently account for the low rate of profits and interest in Holland.

(Ricardo 1951-73, 1: 290n.)

Now if our argument regarding the intended placement of the Note holds good, ${ }^{26}$ then the key declaration ' $\mathrm{M}$. Ricardo tire ici une conséquence parfaitement juste du principe établi dans mon Traité' presumably refers to the principle of a falling profit rate due to the rising cost of wage goods which Say claims is to be found in that work. Whether or not such a claim can be made will be discussed in my sixth chapter; but at the very least Say is here expressing loud and clear his accord with the 'very satisfying' explanation given by Ricardo of the falling profit rate and rejection of the Smithian analysis. It will be recalled too that Say also admitted error in having originally denied Ricardo's proposition that agricultural protection raises the corn price but not the profit rate (above, p. 41).

The concessions of 1819 might be said to mark an important stage in the development of Say's canonical bona fides. Also to keep in mind is an observation in the Lettres à M. Malthus which takes for granted falling real wage and profit rates as a consequence of secular increase in corn relative to manufacturing prices, though the tendency is represented as 'very gradual': 
But in proportion as the manufacturing class increased, alimentary produce would become more in demand and dearer with relation to manufactures. The latter would produce diminished profits and wages, which would discourage those engaged in such branches of industry; hence it is easy to conceive how the restrictions which nature imposes on agricultural production, limit the produce of manufacture. But this effect, like all which happens naturally and results from the nature of things, would be very gradual, and attended with fewer inconveniences than any other possible combination.

At the same time, some formulations are ambiguous. For example, in the Lettres Say accepted that the return on capital will tend to decline with accumulation, but could not appreciate Malthus's fears in this regard, 'excessive' saving being self-corrective:

Wherever capital becomes too abundant, the interest which capitalists derive from it becomes too small to balance the privations which they impose upon themselves by their economy. It becomes more and more difficult to find good securities for investing money, which is then placed in foreign securities. The simple course of nature stops many accumulations.

The notion here of diminishing investment opportunities is consistent both with Smith's increasing competition of capitals and Ricardo's rising cost of producing wage goods.

More serious is the fact that, despite the 1819 Note abandoning the former in favour of the latter, there remain other Notes expounding the disavowed doctrine. Say did not do a thorough house-cleaning. Thus we find at one juncture compensation for the upward effect on the price of metals due to rising labour input, exerted by a falling profit rate reflecting expansion of supply relative to demand:

tandis que les frais augmentaient, la masse de l'approvisionnement augmentait aussi, et même surpassait les progrès que la demande faisait de son côté. ... Il faut donc toujours en revenir à cet unique régulateur des prix: la proportion entre l'offre et la demande; ce qu'il faut chercher, c'est ce qui change les quantités offertes ou demandées, parce que cela seul influe sur les prix. Les profits eux-mêmes, fût-ce ceux du fonds, sont soumis à cette loi comme tout le reste, et varient selon les circonstances qui font varier la quantité offerte ou demandée du service de ces mêmes fonds. 


\section{The 'subsistence' wage and population size}

It is not generally realised that Say applied strict subsistence-wage reasoning in the case of unskilled labour. His strong position in this regard appears in his discussion 'Des Profits de l'Ouvrier' in the Traité, referring to workers 'dont l'ouvrage n'exige point ou presque point d'étude' (Say 1814, 2: 79n.; 1817, 2: 88n.; 1819a, 2: 106n.). The analysis follows the standard classical perception of 'subsistence' as that real wage at which population size (the labour force) remains unchanged:

Les travaux simples et grossiers pouvant être exécutés par tout homme, pourvu qu'il soit en vie et en santé, la condition de vivre est la seule requise pour que de tels travaux soient mis dans la circulation. C'est pour cela que le salaire de ces travaux ne s'élève guère, en chaque pays, au-delà de ce qui est rigoureusement nécessaire pour y vivre, et que le nombre des concurrens s'y élève toujours au niveau de la demande qui en est faite [added 1817, 1819: et trop souvent l'excède]; car la difficulté n'est pas de naître, c'est de subsister. Du moment qu'il ne faut que subsister pour s'acquitter d'un travail, et que ce travail suffit pour pourvoir à cette existence, elle a lieu.

(Say 1814, 2: 78-9; 1817, 2: 87-8; 1819a, 2: 106-7)

A qualification allows for a supplement to cover maintenance of the worker's replacement in the labour market: 'Il faut donc que . . . les ouvriers gagnent un salaire un peu supérieur à leur simple existence; c'est-à-dire qu'ils gagnent de quoi s'entretenir, et, de plus, de quoi élever leurs enfans.' Should the wage fall below the subsistence level there results a fall in population size, leading to an appropriate upward correction of the wage:

Si le salaire des ouvriers les plus grossiers ne leur permettait pas d'entretenir une famille et d'élever des enfans, le nombre de ces ouvriers ne serait pas tenu au complet. La demande de leur travail deviendrait supérieure à la quantité de ce travail qui pourrait être mise en circulation; le taux de leur salaire hausserait, jusqu'à ce que cette classe fût de nouveau en état d'élever des enfans en nombre suffisant pour satisfaire à la quantité de travail demandé.

$(1814,2: 80 ; 1817,2: 89 ; 1819 a, 2: 107-8)^{27}$

Say points out that to avoid this sort of adjustment the entrepreneur was prepared to hire married workers at a slightly higher cost than would be required to pay a single worker:

Ainsi, quand même il ne conviendrait pas aux chefs d'entreprises d'employer des ouvriers mariés parce qu'ils sont plus rangés, cela leur conviendrait, dût-il leur en coûter un peu plus, pour éviter de plus 
grands frais de main-d'œuvre qui retomberaient sur eux [1819 added: si la population déclinait].

$$
\text { (1814, 2: 80-1; 1817, 2: 90; 1819a, 2: 108) }
$$

All this must be kept in mind in considering the Say-Ricardo debate set in motion by Ricardo's chapter 'On Gross and Net Revenue'. That chapter was devoted to a critique of the Smithian proposition that national 'power' depends upon the magnitude of the total national income, Ricardo insisting that it is the net income - here identified with rent and profits which is important in this particular context (Ricardo 1951-73, 1: 348). And now we have the spectacle of Say, the hard-line Malthusian, objecting in his Notes that Ricardo's analysis erred by assuming that workers earn 'subsistence' wages in the technical sense of a wage assuring constant population precluding a surplus:

Si j'osais me permettre de faire une critique générale de la doctrine de M. Ricardo et de sa manière de traiter plusieurs questions d'Économie politique, je dirais qu'il donne aux principes qu'il croit justes une telle généralité qu'il en regarde les résultats comme infaillibles. De ce principe que la classe qui vit de salaires ne gagne que ce qui est rigoureusement nécessaire pour se perpétuer et s'entretenir, il tire cette conséquence qu'une industrie qui fait travailler sept millions d'ouvriers, n'est pas plus avantageuse qu'une industrie qui en fait travailler cinq millions; se fondant sur ce que dans l'un et l'autre cas, les ouvriers consommant tout ce qu'ils gagnent; il ne reste pas plus du travail de sept millions que du travail de cinq millions.

(Say 1819b, 2: 222)

Ricardo’s perspective was, Say complained, typically 'Physiocratic':

Cela ressemble tout-à-fait à la doctrine des Économistes du dix-huitième siècle, qui prétendaient que les manufactures ne servaient nullement à la richesse d'un état, parce que la classe salariée consommant une valeur égale à celle qu'elle produisait, ne contribuait en rien à leur fameux produit net.

For Say, on the contrary, a larger population and workforce implied a larger surplus and taxable capacity since the subsistence wage applied only to 'la classe la plus grossière des simples manouvriers' - confirming the analysis in the Traité - and not to skilled workers who are able to save out of their salaries (223). And even were subsistence wages the rule across the board, a larger population was desirable on grounds of national power (223-4); and on utilitarian grounds, Say adding that consumption was the end pupose of all activity: 
Sous le rapport du bonheur, on peut dire de même qu'il y a une plus grande masse de bonheur dans une population de sept millions qui gagne et consomme ce qu'elle gagne, élève sa famille, et jouit de l'exercise de ses facultés, que dans une population de cinq millions.

Ricardo is taken to task for implying that accumulation was the be all and end all: 'Il semblerait que l'homme n'est au monde que pour épargner et accumuler!'

Ricardo's first reaction - it is uncharacteristically harsh - occurs in a letter to James Mill dated 28 December 1818 touching on Say's utilitarian argument for a large population. Say had raised a matter extraneous to Ricardo's proposition, illustrating his broad strategy in the Notes:

I did not expect that you would be satisfied with Say's notes. - Some of them are ingenious, but he does not grapple with the real question in dispute, - he makes a shew of answering it, but he completely evades it. In his note on gross and net revenue - he begs the question; - he first supposes that a part of the revenue received by the labourers is more than their wants require - that is to say is net revenue, and then he says that there is an advantage in increasing the gross revenue altho' you do not thereby increase the net revenue. In what I said on that subject [1951-73, 1: 348-9] I expressly guarded myself, by saying, that Adam Smith had not argued this question on a supposition that by increasing the number of labourers you were increasing the number of human beings susceptible of and enjoying happiness, - but as it regarded the increase of the disposable wealth and power of the country; and yet M Say answers my observations by saying that there would be a greater number of human beings enjoying happiness.

(Ricardo 1951-73, 7: 378-9)

Say's reading of Ricardo had much in common with that by Malthus, and Ricardo also protested in his Notes on Malthus that he was positively not recommending a reduction of the gross produce in favour of a higher net revenue, as he read the attributions to him by both Malthus and Say (Ricardo 1951-73, 2: 382-3); and to the third edition of the Principles Ricardo appended the observation that

M Say has totally misunderstood me in supposing that I have considered as nothing, the happiness of so many human beings. I think the text sufficiently shews that I was confining my remarks to the particular grounds on which Adam Smith had rested it.

(Ricardo 1951-73, 1: 349n) 
Now Malthus believed that Ricardo countenanced an actual reduction in gross produce - implying reduced employment and ultimately reduced population - in the interest of a higher net product consisting of profit and rent alone: 'what is to become of ... the people in the case of such a change?' (Malthus 1820: 425n). Ricardo was right to protest since his was a comparative-statics argument. And Say may have realized this since he does not go quite so far.

As for the prime technical issue, Ricardo did not deny that wages might contain a disposable element, insisting that his limiting net income to profit and rent was a simplifying assumption without substantive purpose:

Mr. Malthus says 'the additional two millions of men would some of them unquestionably have a part of their wages disposable' [Malthus 1820: 425n.]. Then they would have a part of the neat revenue. I do not deny that wages may be such as to give to the labourers a part of the neat revenue - I limited my proposition to the case when wages were too low to afford him any surplus beyond absolute necessaries.

(Ricardo 1951-73, 2: 380-1)

And he added a conciliatory note to the same effect to the third edition of the Principles in reaction to Say's version of the objection:

Perhaps this is expressed too strongly, as more is generally allotted to the labourer under the name of wages, than the absolutely necessary expenses of production. In that case a part of the net produce of the country is received by the labourer, and may be saved or expended by him; or it may enable him to contribute to the defence of the country.

(Ricardo 1951-73, 1: 348n.)

But Ricardo would have easily turned the tables on Say, had he referred to the latter's position, documented above, that the unskilled labourer typically earns a subsistence wage with no surplus element - his 'hard-line' Malthusianism. Ricardo by contrast allows for a general wage rate exceeding subsistence and a disposable element even in the earnings of unskilled labour.

\section{The utility dimension}

We return to value theory and a matter thus far left in abeyance - the role of utility in value formation. In his first and second editions Ricardo complained that Say in the Traite of 1814 'confounded two things which ought always to be kept separate, and which are called by Adam Smith, value in use and value in exchange' (Ricardo 1951-73, 1: 280n.). He paraphrased Say's argument thus: 
if mankind attach value to a thing, it is on account of the uses to which it is applicable. This faculty, which certain things have, of satisfying the various wants of mankind, I call utility. To create objects that have a value of any kind is to create riches, since the utility of things is the first foundation of their value, and it is the value of things which constitutes riches. But we do not create objects: all we can do is to reproduce matter under another form - we can give it utility. Production then is a creation, not of matter but of utility, and it is measured by the value arising from the utility of the object produced. The utility of any object, according to general estimation, is pointed out by the quantity of other commodities for which it will exchange.

Say, he concluded, engaged in circular reasoning:

If we ask M. Say in what riches consist, he tells us in the possession of objects having value. If we then ask him what he means by value, he tells us that things are valuable in proportion as they possess utility. If again we ask him to explain to us by what means we are to judge of the utility of objects, he answers, by their value. Thus then the measure of value is utility, and the measure of utility is value.

Ricardo himself carefully distinguished between total utility and exchange value, the latter 'measured', in a causal sense, by unit cost not utility:

If by an improved machine I can, with the same quantity of labour, make two pair of stockings instead of one, I in no way impair the utility of one pair of stockings, though I diminish their value. If then I had precisely the same quantity of coats, shoes, stockings, and all other things, as before, I should have precisely the same quantity of useful objects, and should therefore be equally rich, if utility were the measure of riches; but I should have a less amount of value, for my stockings would be of only half their former value.

'Utility' - referring to total utility - 'is not the measure of exchangeable value', Ricardo concluded.

Say responded in his Notes to the charge of circular reasoning - that his riches consist in products having values, values being in proportion to utility while the measure of such utility is value. While two goods with equal prices do indicate equal 'degrees of satisfaction', this equality should not be understood to mean that a fall in the price of a commodity implies a fall in utility, for utility might remain high though price declines with a reduction in costs; now by 'utility' Say here refers specifically to total utility, so that his defence in fact concedes to Ricardo that cost, not total 'utility', is 'the measure of exchange value': 


\section{Value, distribution and growth before 1823}

J'ai dit que la valeur qu'on met aux choses est la mesure de leur utilité, de la satisfaction qu'on peut tirer de leur usage, en ce sens, que lorsque deux choses ont le même prix courant, c'est une preuve que les hommes de ce lieu et de ce temps estiment qu'il y a le même degré de satisfaction à retirer de la consommation de l'une ou de l'autre. Mais j'aurais eu trèsgrand tort si l'on pouvait inférer de ce que j'ai dit, que lorsque le prix d'une chose baisse, son utilité diminue. L'utilité d'une chose qui baisse de prix, se rapproche alors de l'utilité de l'air, qui ne coûte rien, quoique fort utile. . . . Du reste, il n'y aurait pas eu de cercle vicieux à dire que la valeur est la mesure de l'utilité de, et l'utilité, la mesure de la valeur, si ces quantités suivaient une marche absolument pareille dans leurs variations; ce qui n'est pas.

(Say 1819b, 2: 89)

In his closing Note to the 'Value and Riches' chapter Say protested at the manner Ricardo addressed his charge against him of self-contradiction by defining riches sometimes in value terms, sometimes in product or utility terms:

M. Ricardo, en rapprochant divers passages pris en plusieurs endroits de mes ouvrages, sans pouvoir citer les développemens que j’y donne, ni les restrictions que j'y mets, y trouve de l'obscurité et des contradictions. Il peut être fondé; mais a-t-il éclairci cette obscurité? a-t-il levé ces contradictions?

But as we have shown, Say's defence concedes Ricardo's position.

* * *

A conspicuous instance of misunderstanding from Say's point of view, as expressed in the Lettres à M. Malthus, is Malthus's complaint that Say along with James Mill and Ricardo -

considered commodities as if they were so many mathematical figures, or arithmetical characters, the relations of which were to be compared, instead of articles of consumption, which must of course be referred to the numbers and wants of the consumers.

(Say 1821 [1820]: 10, citing Malthus 1820: 355)

He protested: 'I have repeated, in a great variety of forms ... that the value of things (the only quality by which they become wealth) is founded on their utility; on the aptitude which they possess to satisfy our wants.' This did not, however, imply that exchange values are solely demand determined, since Say proceeds to cite his Traité (Say 1819a, 2: 5) on the distinction 
between cases where utility is generated but at zero cost and thus zero exchange value, from cases where production costs are entailed, a contrast expressed as one between 'natural' and 'social' riches, the latter alone subject to 'scientific' study since 'they alone are formed, distributed, and destroyed, according to laws which we are able to assign' (1821 [1820]: 11-12). ${ }^{28}$

The first of the Lettres ends with a rendering of Say's perspective on 'production' as utility creation, and on exchange (21-2). His position regarding the latter, Say claimed in the letter dated 10 August 1820 accompanying a presentation copy of the book, was in fact identical to Ricardo's; and he hoped the reformulation of value doctrine would be found an improvement over earlier efforts:

Je désire vivement que les explications que je donne ici de ma doctrine des valeurs, vous satisfasse mieux que celles qui se trouvent dans mes précédens écrits. Cette doctrine me semble maintenant digne d'être adoptée et étendue par vous; et j'attendrai avec impatience les premiers ecrits que vous publierez pour savoir ce que vous en pensez; car je crois avoir montré qu'elle n'est autre que la vôtre en d'autres termes, puisqu'elle admet que la valeur d'une chose n'est que la faculté qu'a cette chose d'obtenir en échange (to command) une quantité quelconque d'utilité: et que cette valeur est proportionnée à la quantité d'utilité qu'elle peut obtenir. Valeur et quantité d'utilité sont donc les termes égaux d'une même équation; et nous ne différons pas vous et moi, lorsque nous fesons entrer, vous, l'un de ces termes, moi, l'autre, dans la définition des richesses.

(Say, 10 August 1820, received 14 October 1820; in Ricardo 1951-73, 8: 280-1)

This apparently accommodating letter takes for granted that exchange values are 'proportional' to utility. Now in the Notes Say had strongly denied that value and utility 'suivaient une marche absolument pareille dans leurs variations' (above, p. 72). There would be grave doubt as to the coherence of Say's position, unless we read his letter as referring to a sort of marginal (or, at least, average) utility rather than the total utility of the Notes. And this may well be his intention, in which case we are witness to a major technical advance on Say's part. It is regrettable that in this specific context he made no attempt to accommodate the cost dimension which we know he also recognized.

Ricardo saw red. And he conveyed his frustration to Malthus:

I quite agree with you in thinking that M. Say's letters to you are not very well done. He does not even defend his own doctrine with particular ability, and on some other of the intricate questions, on which he touches, he appears to be very unsatisfactory.

(9 October 1820; 276) 
To James Mill he wrote rejecting Say's contention that their positions were substantially identical (14 October: 284); and to Trower he observed that the Lettres was 'written with more self satisfaction than its merit deserves' (26 November 1820; 305). ${ }^{29}$ In an important letter to McCulloch (23 November), he extends the objections to Say's revisions in the Traité of 1819:

I have looked over carefully all the new matter in his fourth edition without discovering any thing to induce me to alter the opinion which I have given of the confusion of his ideas respecting value. Utility, riches, value, according to him are all the same thing. A commodity is more valuable because it is more useful. A man is rich in proportion as he is possessed of value - of utility, and it makes no difference whether commodities are of a low value or of a high value.

Ricardo notices in closing the apparent incoherence we remarked on above:

Erroneous as I think these views are he has not the merit of uniformly adhering to them, for he often acknowledges that commodities will fall in value if their cost of production be diminished, altho' they preserve the same utility. The book I think is altogether an able one, but I am quite convinced that $\mathrm{M}$ Say does not see quite through the subject. ${ }^{30}$

Setting aside those 'acknowledgements', Ricardo was under the distinct impression that Say championed a demand or utility theory of exchange value by focusing on the proportionality of value to utility. He expressed his objections in a letter to Malthus even before receiving the presentation copy of the Lettres, basing himself entirely on a total utility conception. Thus - to Malthus on 9 October 1820:

[Say] certainly has not a correct notion of what is meant by value, when he contends that a commodity is valuable in proportion to its utility. This would be true if buyers only regulated the value of commodities; then indeed we might expect that all men would be willing to give a price for things in proportion to the estimation in which they held them, but the fact appears to me to be that the buyers have the least in the world to do in regulating price - it is all done by the competition of the sellers, and however the buyers might be really willing to give more for iron, than for gold, they could not, because the supply would be regulated by the cost of production, and therefore gold would inevitably be in the proportion which it now is to iron, altho' it probably is by all mankind considered as the less useful metal.

(Ricardo 1951-73, 8: 276-7) 
And a month later he mentioned to Malthus certain critical notes he had composed on the Lettres:

I have also written some notes on M. Say's letters to you, with which I am by no means pleased. He is very unjust to me, and evidently does not understand my doctrine.... In Say's works, generally, there is a great mixture of profound thinking, and of egregious blundering. What can induce him to persevere in representing utility and value as the same thing?

(24 November 1820: 301-2)

These notes, no longer extant, apparently contained similar matter to that introduced into the 1821 version of the 'Value and Riches' chapter in the Principles (see editorial note in Ricardo 1951-73; 1: 301n.). ${ }^{31}$

\section{The Say-Ricardo correspondence 1820-2: approaching accord on value theory}

The Say-Ricardo correspondence of 1820-2, turning largely on the revised 1819 Traité and the Lettres à M. Malthus, starts out unpromisingly on 'the utility dimension' as we have seen, reflecting confusion on the part of both parties between marginal and total utility. But it ends with general accord on the theory of value as a whole, an accord explicitily recognized by Ricardo but subject to Say's unawareness of his correspondent's position on the demand-determined margin.

We set out with Ricardo's remark to Say regarding the revised Traité that while the value chapter was 'greatly improved', he was unable yet to 'subscribe to all [its] doctrines' (11 January 1820; Ricardo 1951-73, 8: 149). For one thing, Say had misunderstood Ricardo's labour theory:

I do not say that it is the value of labour which regulates the value of commodities, for that is an opinion I do all in my power to overthrow; but I say that it is the comparative quantity of labour necessary to the production of commodities, which regulates their relative value.

To Ricardo's insistence that relative labour input, not the 'value of labour' or the wage, was the determinant of relative value, Say replied on 2 March 1820 that he could not fathom the difference since the labour dimension was governed by its price which entered into costs as both Ricardo and himself accepted:

Je vous avoue que je ne comprends pas trop la différence que vous établissez entre la valeur du travail qui ne détermine pas la valeur des produits, et la quantité de travail nécessaire à leur production qui détermine la valeur des produits. Il me semble que vous ne pouvez déterminer la quantité et la 
qualité du travail que par le prix que l'on paie pour l'obtenir. C'est du moins ce que j'ai toujours entendu par la quantité de ce service productif que j'ai appelé service industriel.

(Say, in Ricardo 1951-73, 8: 161)

Doubtless there was some misunderstanding between the two, Ricardo referring to the effect on relative prices of a change in the general wage and minimising (or rather here denying) such effect; and Say referring to the structure of wages. Ricardo, in establishing his 'principles', assumed the structure to be given, but of course accepted that, should the assumption be relaxed, any alteration might affect relative prices. But these issues do not detract from the agreement on cost price expressed by Say with crystal clarity at the close of the passage: 'Son prix fait partie des frais de production, et vousmême établissez très-justement que l'ensemble des frais de production règle la valeur du produit.'

Say's declaration accords with Ricardo's position that the doctrine of services (excepting rent) coincided with his own cost theory (recorded above, p. 59). But a letter to Say of 8 May 1821 takes us a major step forward in appreciating the nature of the accord. Ricardo found no substantive difference between the correspondents on absolute cost prices, exception made for rent:

In your doctrine of productive services I almost fully agree, but I submit to you, whether, as rent is the effect of high price, and not the cause of it, it should not be rejected when we estimate the comparative value of commodities. I have two loaves of bread before me, one raised on the very best land in the country, for which there is probably paid $£ 3$ or $£ 4$ per acre for rent; the other raised on land for which there is not paid per acre as many shillings for rent, and yet both loaves are precisely of the same value, and are equally good. You would say that in one the productive service of land was highly paid, while comparatively little was paid for the productive services of capital and labour; while in the other much was paid for the productive services of capital and labour, and little for that of the land.

(Ricardo 1951-73, 8: 379-80)

But while Say's formulation was 'no doubt true', it did not account for movements in relative price as effectively as did his own labour theory:

This is no doubt true, but the information is not useful and can lead to no inference whatever that can guide our future practice. What we wish to know is what the general law is that regulates the value of bread, as compared with the value of other things, and I think we find that one description of bread, namely, that for the raising of which little or no rent is paid, regulates the value of all bread; and that its value in 
relation to other things depends on the comparative quantity of labour bestowed on its production, and the quantity of labour bestowed on the production of those other things.

(Ricardo 1951-73, 8: 380)

So much for the positive economics. In this same letter Ricardo also repeated what he perceived to be the main difference between them despite the reworkings in the 1819 Traité: that is,

the meaning which should be attached to the word 'value'. You use it in the same sense as 'riches' and as 'utility' and it is this part of your valuable work which I am very anxious should have the benefit of your further consideration.

This complaint will be found in all editions of the Principles, including the last which takes account of the changes made to the 1819 Traité. A technical improvement which reduces cost prices entails doubling

the quantity of riches - double the quantity of utility - double the quantity of what Adam Smith calls value in use, but not double the quantity of value, and therefore M. Say cannot be right in considering value, riches, and utility to be synonymous.

(Ricardo 1951-73, 1: 281)

At the same time, he allowed - confirming our reading of the Notes - that 'there are many parts of M. Say's work to which I can confidently refer in support of the doctrine which I maintain, respecting the essential difference between value and riches'; and hoped

that M. Say may, if he should do me the honour to notice these observations in any future edition of his work, give such explanations of his views as may remove the difficulty, which many others, as well as myself, feel in our endeavours to expound them.

A second formulation of the objection also appears in all editions of the Principles:

In contradiction to the opinion of Adam Smith, M. Say ... speaks of the value which is given to commodities by natural agents, such as the sun, the air, the pressure of the atmosphere, \&c., which are sometimes substituted for the labour of man and sometimes concur with him in producing [Say 1814, 1: 27-8; also 1817, 1: 28; 1819a, 1: 28-9; 1826a, 1: 33-4]. But these natural agents, though they add greatly to value in use, never add exchangeable value, of which M. Say is speaking, to a 
commodity: as soon as by the aid of machinery, or by the knowledge of natural philosophy, you oblige natural agents to do the work which was before done by man, the exchangeable value of such work falls accordingly.

(Ricardo 1951-73, 1: 285-6)

'M. Say', Ricardo added in the 1819 and 1821 editions, 'constantly overlooks the essential difference that there is between value in use and value in exchange' (286). From this perspective he rejected Say's complaint that Smith 'attributes to the labour of man alone, the power of producing value', whereas 'value is owing to the action of labour, or rather the industry of man, combined with the action of those agents which nature supplies, and with that of capital' (Say 1814, 1: li-lii; see for the identical statement, Say 1817, 1: xlix; 1819a, 1: liii; 1826a, 1: lxv-lxvi). ${ }^{32}$ Say's reading was unjustified since 'Adam Smith no where undervalues the services which these natural agents and machinery perform for us', but

they are serviceable to us, by increasing the abundance of productions, by making men richer, by adding to value in use; but as they perform their work gratuitously, as nothing is paid for the use of air, of heat, and of water, the assistance which they afford us, adds nothing to value in exchange.

(Ricardo 1951-73, 1: 286-7)

In all this Ricardo is giving Say a lesson in the scarcity principle underlying price or exchange value. But the fact is that he goes on in the 1817 and 1819 editions to remind readers that Say himself had recognized the 'obstacles in the way of gratuitous enjoyment', those obstacles engendering 'a real expense of production' (287n., citing Say 1814, 2: 3-4; see above, pp. 27-8). Say really knew better than to confuse value in use and value in exchange. Now Say's letter of 10 September 1815 on cost of production as determinant of exchange value (above, p. 28) as well as his Notes of 1819 (above, p. 32) confirm all of this. But so too does a reply of 19 July 1821. In this letter, Say formulates a simple scarcity condition for value in exchange, that is the condition that costs of production be entailed; indeed, it is precisely those costs that determine the relevant degree of utility. We shall demonstrate. ${ }^{33}$

Say found it an outrageous suggestion that he should reconsider his position regarding riches measured in terms of exchange value. It was precisely what he had sought to do in response to Ricardo's earlier objections: 'Je l'avais déjà fait à l'époque où je fus critiqué par vous dans votre première édition; j'ai recommencé le même examen en publiant la quatrième édition de mon Traité d'Economie politique' (19 July 1821; in Ricardo 1951-73, 9: 32). He stood by this position: 'cette doctrine me semble toujours conforme aux faits (qui sont nos maîtres à tous) et qu'à mes yeux elle ne laisse sans explication aucun des phénomènes de l'Economie politique'. And he was incorporating it in an 
ambitious work in the course of preparation, alluding to the Cours complet. More specifically, he rejected the concept value in use as unhelpful since 'value' entails an exchange relation - indeed the expression 'value in use' was a contradiction in terms; and though he allowed to Ricardo that to create utility is to create riches, the only measure of such utility was that provided by exchange value, quantifiability being the sine qua non of science:

Elle a de plus l'avantage de raisonner sur des quantités appréciables, caractère essentiel de toute doctrine scientifique, caractère qui peut seul assurer la marche des investigateurs. Car enfin pour savoir ce qui fait grandir ou diminuer nos biens, il faut savoir ce qui les constitue grands ou petits. C'est, permettez-moi de vous le dire, ce que ne peut enseigner la considération de la valeur en utilité (value in use) mots qui me paraissent incompatibles, parce que l'idée de valeur ne peut être séparée de celle de comparaison et d'échange.

In conclusion:

Je persiste donc à croire que créer de l'utilité c'est créer de la richesse, mais que nous n'avons d'autre mesure de cette utilité créée, que la plus ou moins grande quantité d'un autre produit quelconque; quantité qui forme la valeur échangeable du premier, son prix-courant.

It was precisely because political economy had no interest in utility as such, that 'richesse naturelle' - free goods - were excluded from consideration:

L'utilité qui est naturellement dans une chose, et qui ne lui a pas été donnée, comme celle de l'eau, fait partie de nos richesses naturelles; mais n'ayant aucune valeur échangeable, elle ne peut être l'objet de recherches de la science économique. Et pourquoi l'eau n'a t'elle point de valeur échangeable? Parce qu'elle n'est pas un sujet d'échange, parce que, pour en avoir, personne n'étant obligé d'en acquérir, elle n'est l'objet d'aucune demande.

Now all that is intended by an 'absence of demand' (as for water) is that no one is willing to pay for a commodity that is not scarce. And in what follows immediately a simple scarcity condition for value in exchange is indicated by the requirement for inclusion in the science, that costs of production be entailed:

Une grande utilité qui peut se donner à peu de frais, rapproche la chose à laquelle elle est conferée, d'une richesse naturelle, d'une chose qui a son utilité par elle même et sans frais; mais en Economie politique, nous ne pouvons nous occuper que de la portion d'utilité qui a été donnée avec des frais. 
And this is the response Say gives to Ricardo's main objection in the Principles that 'Mr. Say constantly overlooks the essential difference that there is between value in use, and value in exchange':

Certainement je néglige ce qui n'a qu'une valeur d'utilité, ou plutot de l'utilité sans valeur, car je regarde ces mots: valeur d'utilité (value in use) comme un contre sens; et que je prétends que l'utilité sans valeur n’entre pas dans les considérations de l'Economie politique.

Fully to appreciate Say's position we should also consider his response to Ricardo's challenge in the 1821 edition: 'When I give 2000 times more cloth for a pound of gold than I give for a pound of iron, does it prove that I attach 2000 times more utility to gold that I do to iron?' (Ricardo 1951-73, 1: 283). Ricardo's own answer to this question - and he insists, quite rightly as we shall see, that it has Say's stamp of authority - is of course cost based:

certainly not; it proves only as admitted by M. Say . . that the cost of production of gold is 2000 times greater than the cost of production of iron. If the cost of production of the two metals were the same, I should give the same price for them; but if utility were the measure of value, it is probable I should give more for the iron. It is the competition of the producers 'who are perpetually employed in comparing the cost of production with the value of the thing produced' ... [Say 1819, 2: 508] which regulates the value of different commodities. If, then, I give one shilling for a loaf, and 21 shillings for a guinea, it is no proof that this in my estimation is the comparative measure of their utility.

Ricardo evidently understands utility here as a sort of 'usefulness', iron exceeding gold pound for pound in that regard in a permanent order. Had he proceeded in terms of neutral desirability it might have been easier to appreciate that at the cost-determined price ratio of 2000:1 the marginal utilities would in fact also be 2000:1. Now the same can be said of Say's response in the letter of 19 July 1821 to Ricardo's initial question. For it proceeds on the working assumption of equal utilities - 'un service parfaitement égal' - and proposes that iron conveys 1999 units of utility reflecting the contribution of 'nature' (which did not concern economics), and 1 unit reflecting costs (he includes land as well as labour and capital):

Non; mais en supposant pour un moment qu'une livre d'or et une livre de fer rendent à l'homme un service parfaitement égal malgré l'inégalité de leur valeur, je dis qu'il y a dans une livre de fer: 1999 degrés d'utilité naturelle faisant partie des richesses que la nature ne nous fait pas payer, et qui ne concernent pas l'Economie politique; et 1 degré d'utilité créée par l'industrie, les capitaux et les terres, utilité que nous payons et qui est 
la seule qui fasse partie des richesses échangeables, unique objet de nos recherches. 2000 degrés d'utilité en tout, résidans dans une livre de fer.

(Say, in Ricardo 1951-73, 9: 33-4)

By contrast, all 2,000 utility units yielded by gold reflect costs:

Tandis que dans une livre d'or il y a: 2000 degrés d'utilité tout entière échangeable parce qu'elle est tout entière le fruit de notre industrie, de nos capitaux et de nos terres; utilité qui fait partie, non de nos richesses naturelles, mais de nos richesses sociales, les seules dont l'Economie politique puisse s'occuper.

One further passage in the letter to Ricardo of 19 July 1821 reveals the substantive agreement on cost pricing notwithstanding all appearance. It is a very nice statement indeed of standard classical doctrine reflecting the market-natural-price distinction, expresed in demand-supply terms, such that in equilibrium the various 'services' receive uniform rates of return:

Vous ajoutez: "What we wish to know is what the general law is that regulates the value of bread as compared with the value of other things.'

C'est ce qu'enseigne la doctrine de l'offre et de la demande (want and supply). Le besoin qu'on a d'une chose en fait naître la demande; la nécessité de produire la chose en restreint la demande. Lorsqu'aux yeux du consommateur, une chose vaut autant que les frais de production qu'elle coûte, on la produit. Lorsque la valeur qu'on y attache n'égale pas la valeur des services productifs nécessaires pour qu'elle existe, on ne la produit pas. Cette dernière circonstance est une preuve que la même quantité de services productifs peut former un produit qu'on estime valoir plus que cette chose.

(Say, in Ricardo 1951-73, 9: 35)

Clearly, what mattered for Say operationally is the determination of equilibrium exchange ratios by relative costs; that relative prices measure or provide an index of relative utilities - it is implicitly relative marginal, not total, utility that is intended - in no way reflects causation. ${ }^{35}$

It is in these terms that we can appreciate Say's complaint in May 1821 that his English translator, Prinsep, had repeatedly charged him with a neglect of 'difficulty of attainment' in value formation, whereas the entire 'services' terminology in fact referred to costs:

Je montre ensuite que ces travaux de l'industrie secondée par les instruments qu'elle emploie, constituent des frais de production, et que les gens qui ont fait ces frais n'en cèdent les produits qu'autant qu'on leur donne en échange d'autres produits qui ont coûté des frais équivalents, c'està-dire les mêmes difficulties of attainment. Voilà, dis-je, ce qui constitue 
la valeur échangeable, la seule qui entre dans les considérations de l'économie politique, within the province of politial economy; ce sont les propres mots de votre traduction. Comment, dès lors, pouvez-vous me reprocher de ne point faire mention de ces difficultés, de ces frais dont je parle durant tout le cours de l'ouvrage sous le nom de services productifs, de frais de production, que vous traduisez vous-même par les mots productive agency, cost of production?

C'est donc bien inutilement, Monsieur, que chaque fois que je parle de l'utilité donnée à une chose, et de la valeur qui résulte de l'action de l'industrie, vous prenez la peine de me corriger et que vous surchargez votre traduction de notes pour me reprocher de ne point faire mention de the difficulty of attainment, comme si cette difficulté n'était pas une chose convenue et même positivement exprimée chaque fois qu'il est question de déterminer le prix courant des produits qui ne saurait, d'une manière suivie, tomber au-dessous des frais de production, cost of production, lesquels ne sont autre chose que le prix qu'il faut payer pour vaincre la difficulté d'obtenir, the difficulty of attainment.

(Say 1848: 432-3)

*** $*$

Say and Ricardo were operating on the same wavelength, for a sea-change in Ricardo's hitherto negative evaluation is discernible in his belated response of 5 March 1822 to Say's letter of 19 July $1821 .{ }^{36}$ Here in most accommodating fashion, he asserted that their value doctrines were very close though differently expressed:

I am happy to observe that the difference between us is much less than I had bitherto considered it. You speak of two different utilities which commodities possess, one, which they derive from nature, without any of the labour of man, the other, which they derive exclusively from his labour. You say that from the first of these, which you call natural utility, nothing valuable can be obtained in exchange, and it is only for that portion of utility which is given to a commodity by labour or industry, for which anything valuable can be obtained. You add 'mais en Economie Politique nous ne pouvons nous occuper que de la portion d'utilité qui a été donné avec des frais' [above, p. 79]. You explain on these principles the case I had put to you of a pound of iron and a pound of gold, which I had supposed had exactly the same utility, ${ }^{37}$ though the gold was 2000 times more valuable. If we give 2000 times more for the gold than the iron, you say, it is because that particular utility of which only Political Economy treats, namely that given by labour, is 2000 times greater than that given to iron, and you add that the iron has 1999 portions of natural utility for which nothing is given; of which the gold has none. 
Although I cannot quite approve of the terms used to explain this truth, yet I do now, and always have substantially agreed in the reasoning which proves it, for I have always contended that commodities are valuable in proportion to the quantity of labour bestowed upon them, and when you say that they are valuable in proportion as they are useful, and they are useful in proportion to the quantity of labour or industry bestowed upon them, you are in fact expressing the same opinion in other words.

(Ricardo 1951-73, 9: 168-9; emphasis added)

This letter of March 1822 amply confirms the common ground. It is very different indeed from Ricardo's earlier response to Say's own attempt at accommodation when he sent Ricardo a copy of the Lettres à M. Maltbus. ${ }^{38}$ Say had then failed to convince Ricardo probably because he neglected to spell out explicitly in the manner of his letter of 19 July 1821 that exchange ratios, though they reflect or measure utilities, are determined by relative costs.

We must, though, take account of Say's apparent objection that he alone - by his 'natural'-'social' distinction - excluded free goods from the 'riches' category, and included only goods subject to a cost constraint and thus having exchange value. But Ricardo in fact took this position precisely, maintaining that riches, though indeed comprised of scarce goods only, could not be measured in terms of the relevant exchange values as Say would have it. It was this issue of measurement alone that separated the protagonists. Ricardo's position in this regard is elaborated in the letter of 5 March 1822 when he takes up the test case of a new process which, by allowing use of free natural forces, halves labour input requirements. In such a case Ricardo would insist that any given quantity of the product constituted the same amount of 'riches', or utility, since the product's use value is independent of cost considerations; whereas Say would insist that riches had halved measuring, as he purported to do, riches by exchange value (5 March 1822; Ricardo 1951-73, 9: 169). But even this apparent difference turns out to be a mirage as will emerge in Chapter 4.

$$
* * *
$$

We turn now to Say's response of 19 July 1821 to Ricardo's observations of 8 May regarding differential rent (above, p. 76), specifically 'l'exemple ingénieux ... de deux pains d'égale valeur, provenus de deux terrains d'inégale fertilité' (Say, in Ricardo 1951-73, 9: 34). Say does not proceed positively to reject the no-rent margin but rather bypasses it, representing land rent as a pure scarcity or 'monopoly' phenomenon such that given the demand for land services, rent is higher the more limited its supply:

La nature fait présent au propriétaire du terrain, d'un service productif qu'il peut faire payer au consommateur, parce qu'il a le monopole de ce service indispensable. Ce présent que lui fait la nature, est plus grand 
lorsque le terrain est fertile.... Si le service du terrain était sans bornes, inépuisable, à la portée de tout le monde, ce serait un présent fait à tout le monde et dont nous jouirions sans le payer, comme du vent qui enfle nos voiles, chaque fois que nous voulons nous en servir. Le consommateur serait infiniment riche s'il pouvait acquérir au même prix toutes les portions d'utilité qu'il voudrait consacrer à la satisfaction de ses besoins; mais toutes ses richesses seraient naturelles: elles n'auraient plus de valeur échangeable; il n'y aurait plus d'Economie politique; mais l'on n'en aurait plus besoin.

(Say, in Ricardo 1951-73, 9: 34-5)

Now Ricardo, responding on 5 March 1822, was happy with the formulation in terms of scarcity, and readily adopted the terminology 'monopoly of land of a certain fertility' in stating his own doctrine of differentials, reiterating as always that land is rent free at the margin:

On the ... point respecting the circumstances which make two loaves raised on land of unequal fertility of equal value, although the rent derived from them will be different, we in many respects agree. Rent is the effect of the monopoly of land of a certain fertility, and must rise with the value of the loaf, and with the difficulty of producing additional loaves. But the last loaf produced pays little or no rent, and its value, as well as the value of all other loaves, rises, because a greater quantity of its utility is derived from labour and industry, and a smaller quantity from natural means.

(Ricardo 1951-73, 9: 171-2)

Beyond this, Ricardo also accepted Say's formulation in terms of demandsupply pricing (above, p. 81):

You say demand and supply regulates the price of bread; that is true, but what regulates supply? the cost of production, - the quantity of utility imparted to bread by industry. Rent is the effect of high price, not the cause. In some loaves there must necessarily be little rent, I should say no rent at all.

And Say's rendition of costs in terms of 'services' was equally acceptable, though, as in his letter of 8 May 1821 (above, p. 76), he preferred his own because of its greater precision:

You say bread is regulated in value by productive services, true but in some bread of five shillings value the productive services may be divided thus Rent 2/- Profit 1/- and labour 2/- and in another equal quantity of bread of the same value they may be divided as follows Rent nothing, Profit 1/- and labour 4/-. I object to the lumping the 
productive services altogether, I want to know the part which each performs in giving value to bread.

The acceptance by Ricardo of Say's dual position that 'demand and supply regulates the price of bread' and that 'bread is regulated in value by productive services' is of the highest doctrinal significance. We have here in effect a statement of long-run equilibrium such that market price equals cost. Here too we find the emphasis on the primacy of supply in answer to the question: 'What regulates supply? the cost of production.' This must be kept in mind to avoid any misreading of that earlier observation by Ricardo in writing to Malthus (9 October 1820) regarding Say's Lettres, which might give an impression of the irrelevance of demand (above, p. 74).

Say unfortunately fell into this common misreading. For a note in Say's handwriting attached to the manuscript of Ricardo's letter of 5 March 1822 accepting the dual proposition regarding price, that price is determined by 'demand and supply' and by 'productive services' or costs, overlooks Ricardo's approval of the first element, and insists - as if it were Say's position alone that the productive-services doctrine governs supply conditions only:

Je ne dis pas que les services productifs seuls déterminent le prix du pain; ils déterminent l'offre; mais le prix n'est pas le résultat de l'offre seule. Il est le résultat de l'offre combinée avec la demande. Or c'est le besoin qu'on a de pain accompagné de l'offre de le payer au prix où l'on en demande une quantité quelconque, qui est ce que j'appelle la quantité demandée ou l'autre élément du prix. ... Je ne dis pas Bread is regulated in value by productive services, je dis: Supply is regulated by productive services, but supply is only one of the elements of price.

(Say, in Ricardo 1951-73, 9: 172n.)

Furthermore, Say goes on to point out that, unlike the return to labour and capital, rent - perceived as a surplus - might fall to zero upon a contraction of demand:

Si le besoin de pain est tel qu'on en demande une quantité de ... à 5 Shillings; et que le travail pour créer cette quantité de pain coûte dans un terrain déterminé 2 Shillings, l'intérêt du capital 1 shilling le profit de la terre (Rent) sera 2. Si le besoin est moins grand ou la société moins riche au point que l'on ne puisse plus demander la même quantité de pain qu'au prix de 3 Shillings alors il y aura 2 Shillings pour le travail: 1 shilling pour le capital et rien pour la terre.

Say writes as if oblivious that for Ricardo too rent falls as differentials are reduced upon a contraction of the demand-determined margin. But the fact remains that Say was expounding canonical doctrine. 


\section{Value, distribution and growth after 1823}

\section{Cost-price analysis}

This chapter considers Say's perspective on value and distribution after Ricardo's death in 1823 . Here we investigate the claim that a reorientation of substantive position, increasingly hostile to the British economists, is discernable (above, p. 18).

We set out by comparing the three items cited by Ricardo in 1821 from the Epitome in the fourth (1819) edition of the Traité as indicating Say's acceptable cost doctrine (above, p. 58) with those in the fifth edition of 1826. We shall consider the full context (above pp. 59-61) in each case. It emerges from the exercise that Say's classical cost analysis is as strong as ever.

The first of the three items (1819a, 2: 457) remains unchanged between 1819 and 1826 apart from italicization (1826a, 3: 273). As for the second (1819a, 2: 504-5), we find a yet sharper definition of costs of production in the revised version than in 1819: 'Ce sont les services rendus par l'homme, les capitaux et les agens naturels dans l'œuvre de la production. Leur prix, quand le service rendu n'est pas gratuit, compose les frais de production' (1826a, 3: 325). On the other hand, in the revisions, our two paragraphs containing Ricardo's brief citations are omitted. Since the second merely restates the notion of costs as the price of services consumed it is inconsequential for us. But we must look more closely at the other alteration.

The first paragraph of 1819 points out that the exchange of two products implies an exchange of the services involved in their production, and here mobility of services between uses is taken for granted. In 1826, Say focuses by contrast on cases of immobility, especially specialized land or labour services:

Les services productifs qui se trouvent avoir un mérite spécial et qui ne peuvent être suppléés par d'autres, exercent une sorte de monopole qui en élève le prix, lorsque d'ailleurs les circonstances font demander les produits qui en résultent ... ; ces services étant alors plus demandés que d'autres à proportion de leur quantité offerte, leur prix n'a de bornes que celles qu'y mettent les goûts et les facultés des consommateurs. 
A footnote attached to the first paragraph in 1819 (1819a, 2: 504-5n.) touching on the transfer of services between industries, in the event of a technical change in one of them, also disappears.

These modifications do not positively reject the mobility assumption; they merely direct attention to an alternative. But this is not the case in the third of the entries, on VALEUR DES CHOSES, where Say in 1826 provides a reduced-form version of the original and adds a phrase to the second of the 'deux fondemens' of value, namely utility and costs:

VALEUR DES CHOSES, valeur échangeable, valeur appréciative des choses. C'est ce qu'une chose vaut; c'est la quantité d'autres choses évaluables qu'on peut obtenir en échange d'elle. La valeur de chaque chose est le résultat de l'évaluation contradictoire faite entre celui qui en a besoin, ou qui la demande; et celui qui la produit, ou qui l'offre. Ses deux fondemens sont donc: 1. L'utilité qui détermine la demande qu'on en fait; 2 Les frais de sa production qui bornent l'étendue de cette demande; car on cesse de demander ce qui coûte trop de frais de production. Lorsque son utilité n'élève pas sa valeur au niveau de ses frais de production, la chose ne vaut pas ce qu'elle coûte.

(1826a, 3: 328-9)

Here Say does not merely cut short the analysis of the case where "la chose ne vaut pas ce qu'elle coûte', leaving it to the reader to provide the sequence involving exit of services in a quest for preferable opportunities as spelled out in 1819; he seems rather to direct the reader away from such a sequence by focusing on the extreme case where costs exceed demand prices so that the product is no longer produced at all, a notion of which Say was fond (e.g. 1826a, 2: 167; 3: 293). Though in this case services will presumably transfer to other sectors, the contrast between the accounts of 1819 and 1826 perhaps suggests that Say was somewhat adjusting his sights.

Yet there certainly was no fully fledged rejection of the standard or Ricardian cost-price analysis. One needs only look at the entry under PRODUCTION, PRODUIRE to be convinced of that, for the competitive process involving supply adjustment whereby market price tends to cost price is formulated with eminent clarity:

Quand le produit vaut plus que les services productifs nécessaires pour le créer, les services, ou une partie d'entre eux, tels que ceux de l'entrepreneur, sont plus largement payés. L'effet de cette circonstance est de multiplier les producteurs dans ce genre de production, jusqu'à ce que la concurrence ait amené le produit à ne plus valoir que ses frais de production.

(1826a, 3: 309-10)

The adjustment mechanism appears again under the entry SPECULATION as in 1817 and 1819 (326). 
When we extend our coverage beyond the Epitome to the Traité proper we find further incontrovertible evidence that Say in 1826 reconfirms his earlier position on the relationship between the values of final products and of factor services, whereby entrepreneurs are continually engaged in comparing market prices of particular commodities with cost price in order to make production decisions:

Les entrepreneurs d'industrie ne sont, pour ainsi dire, que des intermédiaires qui réclament les services productifs nécessaires pour tel produit en proportion de la demande qu'on fait de ce produit. Le cultivateur, le manufacturier . . comparent perpétuellement le prix que le consommateur veut et peut mettre à telle ou telle marchandise, avec les frais qui seront nécessaires pour qu'elle soit produite.

(1826a, 2: 229-30; also 1814, 2: 45-6; $1817,2: 53-4 ; 1819 a, 2: 67-8)^{1}$

An opinion that "the "Austrian" turn, i.e., something that looked like imputation theory' was abandoned after the 1819 Traité (Steiner 1998b: 234-5) goes too far. Notwithstanding the deletions and modifications of 1826, Say reiterates the derived-demand principle, clarifying that only the demand prices of productive services are determined thereby; thus once entrepreneurs reach a decision to produce, 'ils établissent une demande de tous les services productifs qui devront y concourir et fournissent ainsi une des bases de la valeur de ces services' (emphasis added). For there is also the matter of service supply:

D'un autre côté, les agens de la production, hommes et choses, terres, capitaux, ou gens industrieux, s'offrent plus ou moins, suivant divers motifs auxquels nous remonterons dans les chapitres qui suivent, et forment ainsi l'autre base de la valeur qui s'établit pour ces mêmes services.

(1826a, 2: 230; also 1814, 2: 46; 1817, 2: 54; 1819a, 2: 68)

An important note is here attached in 1826, as in the earlier editions, regarding the merits of a discussion of production before that of value, the sequence later adopted by J. S. Mill. Say's justification turns on the need to obtain a clear idea of the nature of costs of production:

Il m'a semblé que, pour bien connaître les fondemens de la valeur, il fallait savoir en quoi peuvent consister les frais de production, et pour cela, se former d'avance des idées étendues et justes des agens de la production et des services qu'on en peut attendre.

(1826a, 2: 230n.; 1814, 2: 46n.; 1817, 2: 54n.; 1819a, 2: 68n.)

The same orientation will also be found in the chapter 'Des fondemens de la valeur des choses' (Book II, Chapter 1), in a discussion of the lower quantity demanded at higher cost price ('frais de production'): 
De là naît pour chaque produit une certaine quantité recherchée et demandée en chaque lieu, quantité qui est modifiée par le prix auquel il peut être fourni; car plus il revient cher au producteur en raison des frais de production dont il est le résultat, et plus, dans la classification qu'en font les consommateurs, il est reculé et se voit préférer tous les produits capables de procurer une satisfaction plus grande pour le même prix.

(1826a, 2: 161-2)

What is required, Say concludes, is an appreciation of the determinants of costs, or the prices of productive services:

J'ai dit que le prix des produits s'établissait en chaque endroit au taux où les portent leurs frais de production, pourvu que l'utilité qu'on leur donne fasse naître le désir de les acquérir. ... Il nous reste à connaître les bases qui déterminent leurs frais de production, c'est-à-dire qui déterminent le prix des services productifs.

$(169-70)$

The correspondence between the cost theory of price and Say's own services doctrine is clear from the foregoing. In fact, a footnote is attached which is explicit on the matter - the two versions came to the same thing, allowance made for the services to be taken into account, Say as usual erring in the belief that for Ricardo labour alone entered into costs:

Les personnes qui pensent, avec David Ricardo et d'autres, que le travail (et non le concours du travail, des capitaux et des terres) est le seul élément des valeurs, peuvent substituer, dans cette démonstration, le mot travail aux services productifs; elle sera également concluante.

The correspondence is insisted upon strongly in Say's 1824 response to Sismondi:

Un produit qui ne rembourse pas ses frais de production, c'est-à-dire un produit dont la valeur vénale ne paie pas les profits et les salaires indispensables pour le mettre au point de satisfaire les besoins quels qu'ils soient des consommateurs, n'est point un produit, c'est le résultat inerte d'une peine perdue, du moins jusqu'au point où sa valeur vénale demeure au-dessous de ses frais de production. Telles sont les choses dont l'interêt personnel tend constamment à prévenir l'encombrement. Et si la valeur vénale du produit paie les frais de sa production, quel encombrement est à craindre, puisque cette production procure à ceux qui s'en occupent, les profits et les salaires qu'ils sont en droit d'en attendre? 
Cette considération fondamentale nous montre combien sont encore retardés les écrivains qui, en écomonie politique, ont cru pouvoir faire abstraction de la relation qui existe entre la valeur vénale des produits et celle des services productifs. Cette question et beaucoup d'autres sont mises à la portée de tout le monde dans l'ouvrage que je me propose de publier bientôt, et d'après lequel on pourra, je l'espère, se former une idée complète de nos connaissances économiques.

(Say 1848 [1824]: 258n.)

All of this makes it easy to appreciate Ricardo's, and Malthus's, acceptance of the services doctrine (see above, p. 59).

We return to the Traité, and the chapter 'Des variations relatives et des variations réelles dans les prix', for further evidence of the general cost-price perspective. Here Say works with Smithian 'natural price' and even refers to reductions in 'real', 'original' and 'absolute' price when describing the social benefits deriving from technical change. For example: 'Leurs variations réelles sont celles que subissent les frais que coûte leur production', adding in a note 'c'est ce qu'Adam Smith appelle le prix naturel, par opposition avec le prix courant (market price)' (1826a, 2: 176; for similar formulations, see $1814,2: 26 ; 1817,2: 33 ; 1819 a, 2: 33)$. He then traces out the consequences of a fall in the labour input by way of illustration:

Si les frais de production nécessaires pour produire une aune de drap, et qui s'élevaient à 40 francs, ne s'élèvent plus qu'à 30 francs; si, par exemple, cette aune qui exigeait 20 journées de travail à 40 sous, au moyen de quelques procédés plus expéditifs se trouve n'en exiger plus que 15 , le producteur voit sa richesse augmentée de 10 francs pour chaque aune qu'il vend, et personne n'en est plus pauvre; car s'il achète cinq journées de travail de moins, il laisse à l'ouvrier la disposition de son temps; l'ouvrier vend son travail à un autre producteur, au lieu de le vendre au premier.

(Say 1826a, 2: 177; for similar formulations, see 1814, 2: 27-8; 1817, 2: 176-7; 1819a, 2: 32-3)

The advantage to consumers in consequence of 'competition between producers', once the process becomes common knowledge, is then elaborated:

Quand la concurrence des producteurs oblige celui-ci à baisser son prix au niveau des frais de production, ce sont alors les consommateurs du produit qui font leur profit de cette baisse. ... Cette variation de prix est absolue; elle n'entraîne pas un renchérissement équivalent dans l'objet avec lequel l'échange est consommé.

That the social advantage pertains in the long run, in consequence of 'competition', is restated in 1826 in Book II, Chapter 4 'De ce qui fait l'importance de nos revenus', along precisely the same lines as in 1819 (1826a, 2: 224-5; cf. 1819a, 2: 28). ${ }^{2}$ 
The consequences of technical change are expounded over and again in 1826 as in 1819 - elaborating the accounts of 1817 and 1814 - particularly the extension of quantity demanded at lower cost price, all fully in accord with the British doctrine:

La moindre baisse d'un produit étend tellement la classe de ses consommateurs, que toujours, à ma connaissance, la demande a surpassé ce que les mêmes fonds productifs, même perfectionnés, pouvaient produire; et qu'il a toujours fallu, à la suite des perfectionnemens qui ont accru la puissance des services productifs, en consacrer de nouveaux à la confection des produits qui avaient baissé de prix.

(1826a, 2: 184; 1819a, 2: 41; cf. 1814, 2: 32; 1817, 2: 39)

Once more Say proceeds in 'classical' terms to emphasise the net social benefits that flow from cost-saving technology (1826a, 2: 187-8; also 1814, 2: 35-6; 1817, 2: 42-3; 1819a, 2: 43-4); and here he insists against the Physiocrats and 'mercantilist' writers, including Melon and Forbonnais, that technical change affecting wage goods reduces wage costs but not real wages (1826a, 2: 188-9n.; also 1814, 2: 35-6n.; 1817, 2: 43n.; 1819a, 2: 44-5n.). In the 1819 and 1826 editions the complaint is extended to Sismondi:

M. de Sismondi a reproduit les mêmes erreurs dans ses Nouveaux principes d'Economie politique, liv. IV, chap.8, où il regarde la baisse du prix des produits comme un profit fait sur le producteur par le consommateur; il ne fait pas attention que ceuli-ci $[s i c]$, l'ouvrier compris, ne perd rien à donner à meilleur marché s'il a moins de frais à faire.

(1826a, 2: 189n.; 1819a, 2: 45n.)

The cost analysis provided, we may add, a basis for measuring the benefits derived from public works (1814, 2: 282f.; 1817, 2: 292f.; 1819a, 2: 320f.; 1826a, 3: 133f.).

Finally, Say's strong cost orientation is confirmed by his reaction in 1826 to Prinsep's complaint that he had neglected to take account of 'les difficultés de l'exécution des produits (the difficulties of attainment)' in value determination we recall that this is the theme of the letter to Prinsep of May 1821 (above, p. 81) - a complaint relating to Book I of the Traité where 'utility was laid down as the basis ... with regard to positive value', though not to relative value, apparently referring to the contrast between source and determinant of prices. In response Say insisted on utility as governing demand price, while at the same time be conceded fully costs as determinant of price:

[Prinsep] ne s'aperçoit pas que ce qu'il appelle de ce nom, est la même chose que ce que je nomme plus loin les frais de production; car ces frais ne sont que le prix qu'il faut payer pour surmonter les difficultés de l'exécution. 
Il est très-vrai que le prix courant d'un produit ne saurait, d'une manière suivie, tomber au-dessous des frais de sa production; personne alors ne voudrait contribuer à sa création; mais ce ne sont pas les frais que l'on fait pour le produire, qui déterminent le prix que le consommateur consent à y mettre: c'est uniquement son utilité; car on aurait beau surmonter d'immenses difficultés pour produire un objet inutile, personne ne consentirait à les payer. Quand vous présentez un vase au devant d'une fontaine, ce ne sont pas les bords du vase qui amènent l'eau dont il se remplit, quoique ce soient les bords du vase qui empêchent le niveau du liquide de baisser au-dessous d'une certaine hauteur.

(Say 1826a, 1: 6n.)

$$
\text { *** } *
$$

The Cours complet (1828-9) confirms our reading of the Traite of 1826 regarding the late Say-Ricardo relation. Far from indicating rejection of the British themes relating to cost price, the common ground emerges distinctly, even enhanced.

There is the continued reiteration of the cost-price principle, a nice instance appearing in the important chapter 'De l'échange des frais de production contre des produits ...', with its distinctive emphasis on the 'entrepreneur' and with allowance made in costs for 'risk':

Le concours de l'entrepreneur dans l'opération productive, est un concours nécessaire, et sans lequel le produit n'aurait pas lieu. . . Mais nul entrepreneur ne prendrait la peine de réunir ces éléments épars et de courir les risques de cette fabrication, s'il ne prévoyait pas que le produit qui en résultera doit être suffisant, non seulement pour lui rembourser ses avances, mais pour lui donner en outre un profit qui sera le salaire de son temps, de ses talents, de ses peines. Quand l'événement lui prouve qu'il se trompe, il ne continue pas l'entreprise. Si le travail de l'entrepreneur est indispensable, et s'il est nécessairement payé dans toute entreprise qui se soutient, il faut considérer son bénéfice comme un des frais de l'entreprise, comme une des dépenses indispensables pour qu'un produit soit créé.

(Say 1843 [1828-9]: 55)

Say proceeds to expound the consequences of failure of the market price to cover costs, in terms that one can readily find in any Ricardian text of the day, though again with the characteristic attention accorded the entrepreneur (56). Equally forceful statements of cost pricing appear in the chapter 'De la comparaison, dans la pratique, de la somme des frais avec la valeur des produits', dealing with 'les bases, les principes sur lesquels il faut appuyer les conseils que réclame chaque position particulière' (135).

In the chapter 'De la nature et de l'effet des échanges', Say raises the question why prices settle at particular rates: 'Nous savions, à la vérité, 
que l'utilité donnée à une chose, est le fondement de son prix; mais nous ne savions pas pourquoi son prix s'arrête à un taux plutôt qu'à un autre' (158). His response turns entirely on supply conditions:

$\mathrm{Au}$ fait, on ne produit véritablement que lorsque, tous les services productifs étant payés, le produit vaut ses frais de production. Il faut pour cela que le besoin que la société en a, la détermine à en élever le prix à ce point; et il faut de plus que la société n'ait aucun autre moyen plus économique de se le procurer; ... On paye chaque objet le moins qu'on peut; mais on ne le paye plus du tout, du moment que son prix originaire, les frais de sa production, excèdent la satisfaction qui peut résulter de sa consommation.

This account is referred to later in the text, in an illustration involving costs expressed in terms of labour days: 'Les frais de production représentent un certain sacrifice que l'on fait pour produire une certaine satisfaction; si nous voulons nous représenter nettement ce sacrifice, exprimons-le par un nombre de jours de travail' (323). Most important - albeit tucked away in a footnote - is Say's explanation that costs can fairly be said to determine the lowest level to which price can descend - an old refrain - but are best seen not as a 'cause' of price but as restraints, 'des empêchements'; he certainly did not exclude 'difficulty of attainment' as Prinsep, the English translator of his Traité, had complained was the case:

Voilà la raison pour laquelle j'ai commencé dans ce Cours complet par établir nettement en quoi consistent les besoins de la société. Ce qu'il y a de vrai dans la proposition de Smith, c'est que le prix ne peut pas descendre au-dessous des frais de production, quand les besoins de la société ne suffisent pas pour l'élever jusque-là; mais des frais ne sont pas une cause: ce sont des empêchements. C'est ce que n'a pas compris le traducteur anglais de mon Traité d'économie politique, qui me reproche toujours de ne pas faire mention parmi les causes du prix, of the difficulties of attainment.

(363n.)

Here Say is once again repeating the protestation of his letter to Prinsep in May 1821.

A chapter on 'le prix courant et de la manière dont il s'établit' elaborates the tendency to cost price with specification of the mechanism assuring this outcome. The analysis sets out by distinguishing between price as 'cause' and as 'effect' of demand and supply; the text is unclear as it stands, apparently requiring insertion of 'cost price' as indicated:

On en a tiré la conclusion qu'une chose est d'autant plus chère qu'on en offre moins, et d'autant moins chère qu'on en offre davantage. On n'a 


\section{Value, distribution and growth after 1823}

pas fait attention que la quantité offerte ou demandée est un effet du prix [cost price] qu'ont les choses, et n'en est pas la cause. Dans un échange que l'on traite, on offre beaucoup d'une chose parce qu'elle est à bon marché [at lower cost]; et elle n'est pas à bon marché par la raison qu'on en offre beaucoup.

It remained then to understand 'les causes du prix courant' - he intends long-term equilibrium price - 'dont cette offre et cette demande ne sont que l'effet'. And he proceeds to spell out the supply adjustments assuring such equilibrium:

La quantité de deux marchandises [safran, blé] que l'on peut offrir pour le même prix, c'est-à-dire qui constitue la différence de leurs prix respectifs, c'est, messieurs, la quantité de l'une et de l'autre que l'on peut produire pour les mêmes frais de production.... Je dis qu'elle coûte autant, car si elle coûtait moins, on pourrait avoir du blé à meilleur marché en cultivant du safran, qu'en cultivant le blé lui-même ...; pour faire une aussi bonne spéculation, on cultiverait plus de safran et moins de blé, jusqu'à ce que les quantités respectivement offertes exigeassent des frais égaux. Alors seulement on ne serait pas intéressé à créer un de ces produits préférablement à l'autre.

Quand les choses valent accidentellement plus ou moins que leurs frais de production, elles sont donc à un prix forcé qui tend sans cesse à reprendre son niveau.

All this is in line with the classical canon. Not surprisingly, Say's conclusion is typically orthodox, pointing to the priority of supply in long-run price determination:

C'est ainsi que les frais de production bornent la quantité de chaque produit qui est demandée, et qu'il suffit des suggestions de l'intérêt personnel de chaque producteur, pour que l'on ne fasse de chaque produit que la quantité qu'on en peut consommer au prix où le portent ses frais de production.

There is too the effect of technical change on costs acting via the pressures of 'competition' once the new process becomes common knowledge (173). Cost reductions, Say points out, may affect all industries: 'Et, ce qui est digne de remarque, c'est que le prix originaire, ou les frais de production, et le prix courant qui suit ordinairement ses variations, peuvent baisser pour tous les produits à la fois' (emphasis added). In such a case, 'le prix d'une 
marchandise ne se compare pas avec le prix d'une autre, mais avec les frais de sa production, avec le prix qu'elle coûtait auparavant' (550).

The observation we have italicized above, whereby current prices ordinarily follow the pattern of cost prices, is a generalization of high importance turning on full mobility of services between uses. In our present context:

Ces diverses hypothèses sont fondées sur la supposition que les moyens de production du produit dont il s'agit, du safran par exemple, ne sont pas bornés; que beaucoup plus de terrains qu'il n'en est besoin sont propres à cette culture; et qu'au prix de 60 francs la livre, on peut multiplier le safran de manière à satisfaire toutes les demandes qui pourraient en être faites.

Where this was not the case - as with highly specialized types of land - the analysis required modification in so far as the pattern of final demand affected service returns and thereby played on 'costs':

Cela n'est pas le cas pour tous les produits. Il n'y a qu'une quantité bornée de terrains propres à produire les vins fins. Si les services productifs que rendent les vignobles de la Côte d'Or ne se payaient pas plus cher que les services rendus par les vignobles de Surène, la demande de l'excellent produit qui en sort excéderait beaucoup la quantité qui peut en être fournie. Qu'arrive-t-il? Le prix du vin de Bourgogne monte jusqu'à ce point où la hausse du prix en fait cesser la demande; et le prix auquel les consommateurs consentent à acheter la quantité de vin que fournissent les premiers crus, permet aux propriétaires de ces premiers crus de louer chaque arpent de leurs vignobles plus cher qu'on ne paye le loyer de chaque arpent du coteau du Surène, c'est-à-dire de vendre le service de leur instrument, de leur vigne, plus cher que le service d'un autre bien-fonds.

Say's objection to Ricardo is that while he was correct to insist on cost pricing, he had failed to appreciate that this did not exclude the play of final demand on costs by way of its effect on the prices of specialized services:

David Ricardo soutient que le prix courant des produits est toujours déterminé par les frais de production; et il a raison. Mais il en tire la conséquence que l'étendue de la demande n'influe pas sur ce résultat; et je crois qu'il a tort; car l'étendue de la demande fait monter le prix courant des services nécessaires pour l'espèce du produit, et le produit devient plus cher, quoiqu'il n'excède pas les frais de production.

(171; emphasis added) 
Ricardo's conclusion required the mobility axiom 'que tous les services productifs fussent également propres à tous les produits . . . . Similarly:

Plusieurs économistes politiques sont d'opinion que le prix des choses ne s'augmente pas à cause de la demande, et se règle uniquement sur les frais de production; cette assertion est fondée jusqu'à un certain point; mais les frais de production se composent du prix des services productifs et sont plus chers quand les services productifs sont plus demandés. Avec une même quantité de services productifs offerts, une demande plus grande fait monter à la fois et les frais de production et le prix des produits.

(332n.; emphasis added)

This same perspective will be found also in a more general account of derived demand acting, via the entrepreneur, to raise the prices of 'tous les services qui sont indispensables pour sa création', intending specialized services (320; also 205n.). The case of special talent illustrated strict scarcity and absence of entry generating returns exceeding the competitive rate:

Lorsqu'un produit ne peut être le fruit que d'un talent distingué, le profit qui en résulte excède alors tous ceux qui peuvent être obtenus en vertu des lois précédentes.... Ils retireront en un an dix fois leur capital. C'est qu'il y a fort peu de concurrence dans les talents éminents.

The analysis of the consequences of introducing an immobility assumption is presented by Say as a scientific novelty. He was mistaken. Ricardo had shown long before that constraints on factor supply yield returns in the nature of a demand-determined surplus (above, p. 6). But, unlike Say, he did not represent this outcome as a 'cost price'. To call it thus is a formality - for which reason we have labelled it 'quasi-cost' - and not helpful. Indeed, by this device Say could occupy all positions and even include within a formal cost designation not only the rents enjoyed by special talent but monopoly price quite generally:

Quant au monopole, il ne fait que varier les données; mais il ne change rien à la théorie. Regardez la quantité d'une marchandise que le monopoleur met en vente, comme la quantité que l'on peut obtenir sur la production, et les profits qu'il fait, comme étant des frais de production indispensables, et vous aurez, aussi bien que dans les exemples précédents, un prix qui sera tout à la fois le résultant du rapport entre la demande et l'offre, et l'expression des frais de production.

(Say 1848 [1823]: 291-2) 


\section{Pricing and 'utility'}

Say's cost analysis of prices, assuming service mobility, must be understood subject to his insistence that 'utility' is the ultimate 'source' of exchange value - it is this that contributed to disguise his adherence to classical cost theory - in so far as sacrifices are only made in expectation of the utility inherent in the product:

Or cette qualité qui fait qu'une chose a de la valeur, il est évident que c'est son utilité. Les hommes n'attachent du prix qu'aux choses qui peuvent servir à leur usage; c'est en vertu de cette qualité qu'ils consentent à faire un sacrifice pour les acheter; car on ne donne rien pour se procurer ce qui n'est bon à rien.

(Say 1843 [1828-9]: 38)

None of this dilutes the positive theory of cost pricing. As Say himself had expressed it succinctly in the Traité: 'J'ai dit que le prix des produits s'établissait en chaque endroit au taux où les portent leurs frais de production, pourvu que l'utilité qu'on leur donne fasse naître le désir de les acquérir' (1826a, 2: 169).

The demand component in price determination in the late 1820s effectively reiterates the position as it had emerged in Say's exchange with Ricardo 1820-2, discussed in Chapter 2. By way of background, we note Say's reiteration of the distinction between free goods or richesse naturelle the term 'richesse' here used, he adds, only in a 'philosophical' sense - and true 'richesses', or 'richesses sociales', namely scarce goods resulting from some sort of sacrifice - 'des travaux, des économies, des privations' - and implying the existence of private property:

On ne peut pas séparer de ces biens l'idée de la propriété.... On ne fait point entrer dans l'inventaire d'un homme, les biens naturels dont il a la jouissance en commun avec l'humanité tout entière; mais on y fait entrer cette portion des richesses sociales qui lui appartient personnellement, qu'il a acquise par ses propres soins, ou qu'il tient à titre de don ou d'heritage.

(Say 1843 [1828-9]: 31-2)

Furthermore, scarce goods alone are subject to scientific investigation because of their quantifiability in terms of exchange value:

elles peuvent seules devenir l'objet d'une étude scientifique, car elles seules sont appréciables rigoureusement; seules elles suivent, dans leur formation, leur distribution dans la société, et leur consommation, des règles invariables, où les mêmes causes sont toujours suivies des mêmes effets. 
With this in mind, Say proceeds to technical detail and what used to be referred to as 'the paradox of value':

Tout le monde reconnaît que les choses ont quelquefois une valeur d'utilité fort différente de la valeur d'échange qui est en elles; que l'eau commune, par exemple, n'a presque aucune valeur, quoique fort nécessaire; tandis qu'un diamant a une valeur d'échange considérable, quoiqu'il serve peu. Mais il est évident que la valeur de l'eau fait partie de nos richesses naturelles, qui ne sont pas du domaine de l'économie politique; et que la valeur du diamant fait partie de nos richesses sociales, les seules qui soient du ressort de cette science. ${ }^{3}$

We shall see that Jules Dupuit, one of the undisputed founders and applicators of the marginal-utility doctrine, objected to this formulation, the clumsiness of which becomes apparent when Say attempted to generalize:

Il y a même des objets qui renferment en eux ces deux genres de valeur, et même dans des proportions fort différentes. Il suffit, pour s'en convaincre de comparer la valeur du fer avec celle de l'or. L'or est certainement moins utile que le fer, et cependant il vaut beaucoup plus. C'est qu'il y a dans l'or une très-forte portion de richesse sociale et d'échange; tandis qu'il y a dans le fer, par des raisons qui vous seront expliquées, une faible dose de valeur sociale, et beaucoup de valeur naturelle, qui ne fait point partie de nos richesses sociales.

Despite the inelegance of Say's approach in terms of 'richesses naturelles' and 'richesses sociales', various strictures by Stigler and Schumpeter and earlier by Dupuit are too harsh. Thus Stigler writes that '[i]n order to support the thesis that prices are proportional to utilities' Say was driven to invent the metaphysical distinction between natural and social wealth' (Stigler 1965: 77; emphasis added); ${ }^{4}$ and Schumpeter, that Say 'spoiled his chance [of furthering the Franco-Italian utility approach to value] by his handling of the matter that was still more clumsy than it was superficial and led nowhere' (Schumpeter 1954: 1054). ${ }^{5}$ Say, we suggest, went much further than these comments allow.

We note first that Say gives a satisfactory reading of 'value in use' in terms of general desirability rather than the quasi-physiological sense that might be understood from the discussion of the water-diamond case:

Aux yeux du moraliste, une fleur artificielle, une bague au doigt, peuvent passer pour des objets complètement inutiles. Aux yeux de l'économiste, ils ne sont plus méprisables du moment que les hommes y trouvent assez de jouissances pour y mettre un prix quelconque.

(Say 1843 [1828-9]: 38-9) 
And consistently with his late correspondence with Ricardo (above, pp. 79-81), he proceeds to distinguish between total utility and the utility 'communiqué par l'homme', namely the utility engendered by costs entailed, which effectively amounts to marginal supply price:

C'est l'utilité des choses ainsi conçue qui est le premier fondement de la valeur qu'elles ont; mais il ne s'ensuit pas que leur valeur s'élève au niveau de leur utilité: elle ne s'élève qu'au niveau de l'utilité qui leur a été communiquée par l'homme.

Consequently there resulted a consumer surplus to which is assignable a monetary equivalent:

Le surplus de cette utilité est une richesse naturelle qui ne se fait pas payer. On consentirait peut-être à sacrifier vingt sous pour une livre de sel, s'il fallait la payer en proportion du service qu'elle peut rendre; mais on n'est heureusement obligé de la payer qu'en proportion de la peine qu'elle coûte. Tellement que, s'il vous plaît d'évaluer la jouissance que vous procure cette denrée à vingt sous la livre, et qu'elle ne vous coûte qu'un sou, il y a dans une livre de sel pour 19 sous de richesse naturelle qui vous est donnée gratuitement par l'auteur de la nature, et pour un sou seulement de richesse sociale, c'est-à-dire, de valeur non gratuite donnée par l'homme qui a recueilli le sel et qu'il vous fait payer.

A footnote relating to the market reinforces this reading:

les prix, à mesure qu'ils s'élèvent par les difficultés de la production, bornent le nombre des demandeurs à ceux à qui leurs facultés permettent d'atteindre à l'usage de certaines utilités; ce qui arrête la production de toutes les utilités qui excèdent un certain prix.

Say's position in the Cours complet - as in the late exchange with Ricardo himself (above, pp. 75f.) - is in line with Ricardo's proposition that technical progress reduces per unit value but increases total utility - and, conversely, that with increased scarcity unit value rises but total utility falls. Now this led Marshall to his famous attribution:

in a profound, though very incomplete, discussion of the difference between 'Value and Riches' [Ricardo] seems to be feeling his way towards the distinction between marginal and total utility. For by Riches he means total utility, and he seems to be always on the point of stating that value corresponds to the increment of riches which results 
from that part of the commodity which it is only just worth the while of purchasers to buy; and that when the supply runs short ... there is a rise in that marginal increment of riches which is measured by value, at the same time that there is a diminution in the aggregate riches, the total utility, derived from the commodity.

(Marshall 1920: 814)

If this can be said of Ricardo - and I believe it can - it applies equally to Say. ${ }^{6}$

It follows also that the celebrated strictures against Say by Dupuit go too far. Dupuit applauded Ricardo's adoption of the Smithian distinction between value in use and value in exchange, contrasting it with Say's campaign to displace the former by the latter; for by confining economic science to exchange values, Say had precluded the notion of a surplus utility on intra-marginal units over the marginal unit of consumption. ${ }^{7}$ Dupuit bases his interpretation on the citations encountered above:

L'erreur capitale de J.-B. Say n'est pas d'avoir méconnu la valeur en usage ou utilité, mais de l'avoir repoussée de la science, en y substituant la valeur en échange, qu'il a considérée comme sa mesure, et pouvant, par conséquent, la remplacer. Dans les citations que nous avons faites plus haut, on aura, sans doute, remarqué cette phrase: Tout le monde reconnaît que les choses ont quelquefois une valeur d'utilité fort différente de la valeur d'échange qui est en elles [Say 1843 [1828-9]: 33, cited above, p. 98]. Dans une autre citation: Que la valeur ne s'élève pas au niveau de l'utilité, qu'elle ne s'élève qu'au niveau de l'utilité donnée par l'bomme [paraphrase of Say 1843: 39, cited above, p. 99]. L'utilité et la valeur avaient donc, suivant J.-B. Say, deux niveaux différents; mais il ne voulait pas tenir compte de toute la hauteur dont le niveau d'utilité dépassait celui de la valeur. ${ }^{8}$

(Dupuit 1933 [1853]: 173)

Dupuit's reading is difficult to reconcile with Say's remarkable recognition of a surplus utility generated by the purchase of all units at a price dictated at the margin, a surplus to which corresponded a monetary equivalent.

Having arrived at the above conclusion, it is all the more important to emphasize that Say - again like Ricardo - did not follow through and analyse consumer behaviour as such in utility terms. Say arrived at the equilibrium condition that the long-run price ratio between two products reflects both the marginal-cost and marginal-utility ratios, but beyond that he did not proceed. A revealing index of the absence of a workable notion of marginal utility and a fortiori of diminishing marginal utility appears in a passing remark in the Traité relating to the increase in quantity demanded at lower price: 'le même produit ou plusieurs produits, sans que leur utilité [1826: utilité intrinsèque] soit devenue plus grande, seront [1826: sont] plus demandés à mesure qu'ils seront [1826: sont] à plus bas prix' (Say 1819a, 2: 11; 1826a, 2: 162). 
We turn now to Say's rationalization of the negative demand-price relation. By way of introduction we recall that J. S. Mill distinguished carefully an increase in quantity demanded as price falls from an increase in the entire demand schedule, thereby solving the apparent contradiction that while 'demand ... partly depends on the value ... value depends on the demand' or 'the paradox, of two things, each depending on the other' (Mill 1963-91 [1848], 3: 466). Now, though the equation of demand and supply 'must be familiar to all political economists', Mill was unable to recall any one before himself who had laid it out properly 'except the eminently clear thinker and skillful expositor, J. B. Say'. Mill neglected to provide citations, and it has been argued that '[p]erhaps Say was not very clear that equality between the quantity supplied and the quantity demanded was the price-determining condition, else he would have expressed it by something more specific than rapport' (Smith 1951: 245n. referring to Say 1803, 2: 58). Yet we might on Say's behalf refer to the contrast between movements along and shifts of the demand schedule neatly summarized in the 1819 version of the Traité: 'La consommation des produits augmente quand ils baissent de prix. Elle diminue ou cesse tout-à-fait quand ils haussent.... Les prix s'élèvent en raison directe de la quantité demandée, et en raison inverse de la quantité offerte' (Say 1819a, 2: 418). The Cours à l'Athénée expresses the matter very well:

Vous savez donc généralement parlant quelles sont les causes qui font la quantité offerte, et la quantité demandée de chaque chose ayant une valeur échangeable. Or le raisonnement tout seul suffirait pour nous apprendre (si l'expérience ne le confirmait pas constamment) que la valeur de chaque chose (ou son prix si vous estimez sa valeur en argent) s'élève d'autant plus qu'elle est moins offerte et plus demandée, et que ce même prix s'élève d'autant moins qu'elle est plus offerte et moins demandée. Le point où se rencontrent ces deux intérêts contradictoires, est celui où se fixe la valeur courante, le prix courant des choses qui ont une valeur. Dès lors elles sont une portion de richesse proportionnée à leur valeur.

(Say 1996 [1819]: 106)

The rationing function of price, taking proper account of the demand schedule, is well formulated in the Cours complet in discussing correction of an excess quantity demanded at a given price (Say 1843: 170; see above, p. 95). And the effect of a shift in the demand curve in raising market price, and thus the returns to some or all services, is also clear: 'l'étendue de la demande fait monter le prix courant des services nécessaires pour l'espèce du produit, et le produit devient plus cher, quoiqu'il n'excède pas les frais de production' (171; above p. 95). A particularly striking formulation of equilibration will be cited below (p. 237). 
Our concern now is the basis for the demand curve itself. Say in the Cours complet starts off in terms of a 'Mengerian' classification of utilities: 'Les hommes ... en leur qualité de consommateurs, font une sorte de classement de leurs besoins, selon le degré d'importance qu'ils attachent à la satisfaction de chacun de ces besoins' (1843: 168). But he merely takes this as a datum of 'moral' significance irrelevant for the matter at hand: 'C'est une considération morale de la plus haute importance qu'un classement judicieux de nos besoins; mais ce n'est pas ce qui doit nous occuper ici. Nous ne considérons encore ce classement que comme une chose de fait et d'observation.' He even goes on to dilute the idea of a stable preference ordering: 'Il est de fait que l'on satisfait généralement certains besoins préférablement à d'autres; et l'on accorde en général cette préférence, non d'après un plan arreté d'avance, mais pour obéir aux habitudes prises, ou à l'impulsion du moment.' And though the preference scale is not, after all, abandoned, Say's emphasis is rather on an income effect - as was the common British practice - a stronger supply constraint reflected in higher cost price obliging reduced consumption by the individual and, conversely, a reduced cost price allowing expanded consumption:

C'est de cette préférence accordée à certains produits, à commencer en général par les plus indispensables au soutien de la vie, que se forme la demande générale de tel ou tel produit. Mais cette demande est modifiée par les frais de production qu'exige la création du produit. Quand le produit est cher, c'est-à-dire, lorsqu'il ne peut avoir lieu sans beaucoup de frais de production, la demande qu'on en fait est moindre. Cela doit être nécessairement ainsi; autrement le produit dont il est question absorberait une portion du revenu du consommateur, plus considérable que celle qu'il peut y consacrer. ... C'est pour cette raison que, lorsque les moyens de production viennent à se perfectionner, et que les produits baissent de prix, leur consommation devient tout de suite plus considérable.

The income-based rationale for the market demand-price relation is laid out in a 'tableau' portraying a pyramidal structure describing the pattern of income distribution, a device used as early as 1803 drawing apparently on Garnier (1796) (see Theocharis 1983: 82-4; Ekelund and Thornton 1991: 398-401; Forget 1999: 143; Diemer 2003: 363-6). ${ }^{9}$ The diagram portrays 'comment, à mesure qu'un produit baisse de prix, il rencontre plus de consommateurs, et comment il en rencontre d'autant moins qu'il est plus cher' (Say 1843: 169). Marginal demand price for the market thus emerges clearly, quantity demanded at each (cost) price turning on the numbers of consumers in the appropriate income group, those numbers varying inversely with the price, since wealth is distributed such that individual fortunes are more numerous the smaller they are: 
Les fortunes des particuliers, en tout pays, s'élèvent par des degrés insensibles, depuis les plus petites jusqu'à la plus grande. Elles sont d'autant plus nombreuses qu'elles sont moindres, et deviennent d'autant plus rares qu'elles sont plus grandes. De sorte que l'on pourrait les comparer à cette multitude de lignes verticales qui remplissent une pyramide. Si l'on représente, par une ligne horizontale tracée plus ou moins haut, la hauteur des frais de production d'un produit quelconque, le nombre des lignes verticales qui atteindra cette section représentera le nombre des fortunes capables d'atteindre à ce prix, et par conséquent le nombre des consommateurs du produit. Plus la section sera haute, et moins il y aura de fortunes capables de faire le sacrifice de cette somme de frais. Plus au contraire la section sera basse, plus les frais de production seront réduits, et plus seront nombreuses les fortunes qui pourront faire l'acquisition du produit.

(Say 1843 [1828-9]: 168-9)

The limiting bounds are also defined, the lower limit entailing free goods (Say's 'richesses naturelles'):

Le prix des richesses naturelles, des choses que l'on peut se procurer sans aucuns frais, comme l'air et l'eau, serait représenté par une ligne horizontale inférieure, même à la base de la pyramide; et une ligne qui surpasserait le sommet de la pyramide, représenterait un produit dont les frais de production seraient tellement élevés qu'ils excéderaient les facultés des gens les plus riches.

Say plays some lively tunes on his instrument with an eye to alternative income distributions, portrayed by the height and shape of the pyramid:

Un pays où les fortunes seraient en général très-bornées pourrait être représenté par une pyramide fort surbaissée. Celui où il y aurait beaucoup de petites fortunes et un petit nombre de grandes serait représenté par une pyramide dont les côtés seraient rentrants ou concaves.

And Say indicates his own preference, on grounds of maximum happiness, for a structure with a higher proportion in the middle classes: 'Celui où les fortunes moyennes seraient les plus nombreuses et les extrêmes rares serait représenté par une pyramide dont les côtés seraient bombés ou convexes. Ces derniers pays sont les plus heureux.' Say's preference, incidentally, corresponds with Malthus's view of desirable income distribution (Hollander 1997: 911-14).

Say does, it is true, generalize to include the individual consumer but only briefly: 'La section de la pyramide représente plus exactement encore le 
nombre des proportions de fortune, que chaque particulier peut et veut consacrer à l'acquisition d'un produit qui s'élève à un prix déterminé' (1843: 169n.; emphasis added). Here by his 'peut et veut', Say alludes to underlying preferences, in line with various formulations in the late Traité:

En même temps que la quantité demandée de chaque produit est modifiée par ses frais de production, elle l'est par le nombre de ses consommateurs, par le nombre des personnes qui éprouvent le besoin de le consommer et qui ont en même temps les moyens de se satisfaire.

(1826a, 2: 162; emphasis added)

Similarly: 'Il faudra, pour que ce produit puisse être créé, que ses consommateurs aient la volonté et le pouvoir d'y mettre le prix' (171; emphasis added). But this is far too general, and a further statement proposing a conceptual splitting up of the individual into two is consistent with the usual income effect and absence of any sort of meaningful utility calculation. Thus upon an increase in the price of a commodity,

non-seulement le nombre des consommateurs diminue, mais chaque consammateur réduit sa consommation. Il est tel consommateur de café qui, lorsque cette denrée hausse de prix, peut n'être pas forcé de renoncer entièrement aux douceurs de ce breuvage. Il réduira seulement sa provision accoutumée: alors il faut le considérer comme formant deux individus; l'un disposé à payer le prix demandé, l'autre se désistant de sa demande.

This position, which dates back to the first edition $(1803,2: 71)$, is repeated almost word for word in the Cours complet (1843: 169), with one difference that Say now has only 'un certain nombre des consommateurs' cutting back consumption upon a price increase.

* * *

We take account now of Malthus's estimate of Say's position on utility in the value context. We note first his harsh reaction in writing to Ricardo in 1821, who had passed on to him the long letter from Say dated 19 July 1821 (see p. 78): 'I have always thought his doctrine of utility an abuse of the natural meaning of the term, and even according to his present mode of explanation, much contradiction is involved in it' (13 September 1821; in Ricardo 1951-73, 9: 64). This objection was reiterated after Ricardo's death in Malthus's Quarterly Review article of 1824 on McCulloch's rendition of Ricardian economics. Malthus commended McCulloch for distinguishing between value and utility, but rejected the identification of his own position with that of Say, for he himself had consistently 'adhered to the distinction 
stated by Adam Smith, which is plain and intelligible, and requires neither the rejection nor the alteration of common terms' (Malthus 1986 [1824], 7: 258). Malthus's Definitions spells out the precise objection to Say's use of the term 'utility'. A definition must accord with what is understood in 'common conversation' and also concord with 'the language of those who are considered as the best authorities in political economy' (Malthus 1986 [1827c], 8: 14). Say had violated the rule:

he has strangely identified utility and value, and made the utility of a commodity proportionate to its value, although the custom is universal of distinguishing between that which is useful and that which is merely high priced, of that which is calculated to satisfy the acknowledged and general wants of mankind, and that which may be only calculated to satisfy the capricious tastes of a few.

(Emphasis added)

Later in the Definitions, Malthus again complained of a confusing use of the term 'utility' by Say when he maintained in the Traité (1819a, 2: 506) 'that the price of an article is the measure of its utility, although it might be according to his own expression, la chose la plus inutile' (Malthus 1986 [1827c], 8: 116).

Now we know from the Say-Ricardo exchange of 1820-2 and elsewhere that Say in fact subscribed to a cost theory of long-run price determination (above, pp. 75f.); we have seen as much even in the Lettres à M. Malthus (above, pp. 72-3). And Malthus may have realized this, since later in the Definitions we find a formulation, using Say's terminology, of the cost determination of price: 'the effectual demand for commodities must, on an average, be proportioned to the productive services set in motion to obtain them' (100). ${ }^{11}$ For Say, relative cost prices are proportionate to relative utility; or to be more specific he represents 'utility' - intending utility at the margin rather than total utility - sometimes as synonymous with, or sometimes less strongly as measured by, value in exchange, and in that limited sense he may be said to maintain a utility theory of value. Beyond this he did not go; he did not ascribe to utility a technical role in value formation. Even so, he had gone too far for Malthus.

Better to appreciate Malthus's reaction, we recall that in the Principles he had dismissed 'value in use' as 'metaphorical', descriptive of 'a clear spring of water' or 'fine air' and thus as irrelevant to exchange value (Malthus 1820: 51). The independence of exchange value from 'metaphorical' value in use is strongly formulated in The Measure of Value:

It is generally allowed that the word value, in common language, has two different meanings; one, value in use, the other, value in exchange; the first expressing merely the usefulness of an object in supplying the most important wants of mankind, without reference to its power of 
commanding other objects in exchange; and the second expressing the power of commanding other objects in exchange, without reference to its usefulness in supplying the most important wants of mankind. It is obviously value in the last sense, not the first, with which the science of Political Economy is mainly concerned.

(Malthus 1986 [1823], 7: 181)

But although Say too allowed 'utility' no causative role in value formation, he at least carried matters a step further in that direction by his proportionality approach; he certainly was less dismissive than Malthus. Beyond this there is the 'Marshallian' reading of Ricardo that may be applied to Say as we have argued earlier (above, p. 99).

\section{Service-supply conditions}

We return to costs of production, specifically the proposition that the service returns turn partly on service-supply conditions (above, p. 88). We shall take account, first, of the general wage, interest on capital, the earnings of the entrepreneur and rent, and thereafter of the structure of earnings.

\section{The general wage}

In the analysis of general wages in the 1826 Traité -'Des profits de l'industrie en général' (Book II, Chapter 7, Section 1) - we find the standard classical proposition, as in earlier editions, that they are a function of the relative growth rates of capital and population:

Et d'abord, comparant les profits de l'industrie avec ceux des capitaux et des terres, nous trouverons qu'ils sont plus forts là où des capitaux abondans réclament une grande quantité de qualités industrielles, comme c'était le cas en Hollande avant la révolution. Les services industriels y étaient très-chèrement payés; ils le sont encore dans les pays, comme les États-Unis, où la population, et par conséquent les agens de l'industrie, malgré leur rapide multiplication, restent en arrière de ce que réclament des terres sans bornes [1814: des terres imbornées] et des capitaux journellement grossis par une épargne facile. ${ }^{12}$

(Say 1826a, 2: 256; also 1814, 2: 62; 1817, 2: 72; 1819a, 2: 90)

But subsequently, when dealing with the wages of unskilled labour - 'les travaux simples et grossiers' in his Section 4 'Des profits de l'ouvrier', Say goes much further by providing a very strong formulation of the subsistence wage involving what can only be called hard-line Malthusianism. The formulation is as in the earlier versions (above p. 67), with one variation that further emphasizes the speed of population response: 'Du moment qu'il 
ne faut que subsister pour s'acquitter d'un travail, et que ce travail suffit pour pourvoir à cette subsistance, l'homme capable d'un semblable travail ne tarde pas à exister [1814, 1817, 1819: . . à cette existence, elle a lieu]' (1826a, 2: 277). There follows the same allowance for maintenance of children, the worker's replacement in the labour force; and the same adjustment process should the wage fall below subsistence: 'le taux de leur salaire hausserait, jusqu'à ce que cette classe fût de nouveau en état d'élever des enfans en nombre suffisant pour satisfaire à la quantité de travail demandé' (278). Say thus remained committed to an infinitely elastic, long-run labour-supply function.

\section{The rate of interest}

Even where the entrepreneur uses his own capital, the final price must be such as to cover his own particular services - 'le profit qui le dédommage de ses peines' - and in addition 'la compensation du service rendu par son capital' (301). Here in the 1826 version of Book II, Chapter 8 'Du revenu des capitaux', we find contrasted the contractual payment of interest paid in advance where capital has been borrowed and the residual income obtained by the entrepreneur upon sale of the product which may exceed or fall short of the outlay:

Le revenu d'un capitaliste est déterminé d'avance quand il prête son instrument et en tire un intérêt convenu; il est éventuel et dépend de la valeur qu'aura le produit auquel le capital a concouru, quand l'entrepreneur l'emploie pour son compte. Dans ce cas, le capital, ou la portion du capital qu'il a empruntée et qu'il fait valoir, peut lui rendre plus ou moins que l'intérêt qu'il en paie.

$(301-2)$

The earlier versions had said much the same, though the contrast between a contractual and residual payment was then only implicit (1814, 2: 95; 1817, 2: 104; 1819a, 2: 126).

In addition to interest proper there is an insurance premium paid the lender:

dans le prêt il s'agit ... d'évaluer le risque que court le prêteur, de ne pas rentrer en possession de la totalité ou d'une partie de son capital. Ce risque est apprécié et payé au moyen d'une autre portion d'intérêt ajoutée à la première [le loyer du capital], et qui forme une véritable prime d'assurance.

$$
\text { (1826a, 2: 306; also 1814, 2: 98; 1817, 2: 107; 1819a, 2: 129) }{ }^{13}
$$

Here Say silently follows the Wealth of Nations where the interest rate includes an allowance for the risk of default. ${ }^{14}$ 
As far as concerns interest proper, or 'le véritable loyer qui paie l'utilité et l'usage d'un capital' (1826a, 2: 314; also 1814, 2: 106; 1817, 2: 115; 1819a, 2: 137), we note first a concession introduced in the 1819 edition to Adam Smith 'et ses partisans' that capital itself may be perceived as past labour: 'Ce capital, disent-ils, est lui-même composé de produits qui sont un travail accumulé. J'en conviens' (1819a, 2: 154). Say nonetheless proceeds to insist on the independent contribution of capital, its 'cooperation' in the production process:

mais je distingue la valeur du capital lui-même, de la valeur de sa coopération; de même que je distingue la valeur du fonds de terre, de la valeur de sa coopération; la valeur d'un champ, de la valeur de son loyer. ... Ce capital est un produit antérieur: le profit que j'en ai recueilli dans l'année, est un produit nouveau et tout-à-fait indépendant du travail qui a concouru à la formation du capital lui-même. ${ }^{15}$

This perspective Say saw as confirming the return on capital as the price of a productive service independent of labour:

De ce qui précède, il faut inévitablement tirer la conséquence que le profit du capital, ainsi que celui du fonds de terre, est le prix d'un service qui n'est pas un travail bumain, mais qui est néanmoins un service productif, lequel concourt à la production des richesses, de concert avec le travail humain.

(154-5; emphasis added)

The 1826 edition makes no mention of Smith and withdraws the concession regarding capital as past labour which is now simply attributed to 'des écrivains':

Il est impossible d'adopter l'opinion des écrivains qui pensent que ce prix ne représente que le travail de l'homme. - Les capitaux eux-mêmes, disent-ils, sont le fruit d'un travail antérieur; il faut les considérer comme un travail accumulé. - En premier lieu, ils ne sont pas le fruit du travail uniquement, mais du concours des travaux, des capitaux et des fonds de terre.

(1826a, 2: 337-8)

Say then posits that even were capital reducable to labour alone, it would not be less true that it made an independent contribution generating a return:

en supposant qu'ils fussent le fruit du travail uniquement, il faudrait encore distinguer les produits qui composent le capital, des produits qui résultent de sa coopération. Entre eux se trouve toute la différence d'un fonds à un revenu; la même différence qu'on aperçoit entre une terre et les produits de la terre, entre la valeur d'un champ et la valeur de son 
loyer. Le fonds est le résultat d'un travail antérieur, j'y consens pour un moment; mais le revenu est un nouveau produit, fruit d'une opération récente.

The general conclusion is exactly as in 1819, though now expressed in Sayian utility-oriented terminology, that demand price must be such as to cover the full costs or supply price for a product to be produced, costs including not only wages, including the return to entrepreneurship proper, but also profits or more precisely interest and - Say here also insists - rent:

La retribution qui constitue le profit du capital, fait partie des frais de production des produits qui ne peuvent parvenir à l'existence sans le concours du capital. Pour que de tels produits soient créés, il faut que l'utilité qu'on leur donne élève leur prix assez haut pour rembourser à l'entrepreneur les profits du capital aussi bien que ceux de l'industrie dans tous ses grades, et ceux du fonds de terre.

As for the course of the interest rate proper - the 'prime d'assurance' presumed given - Say adopted the eighteenth-century competition-of-capitals perspective, writing of 'la loi générale et permanente, qui veut que plus les capitaux disponibles sont abondans en proportion de l'étendue des emplois, et plus on voie baisser l'intérêt des capitaux prêtés' (1826a, 2: 316; also 1814, 2: 108; 1817, 2: 116; 1819a, 2: 138). And he also followed tradition in specifying that it is specifically the demand and supply of loanable funds capital in 'circulation' - that governs the interest rate, or that borrowing entails 'une ... portion de la valeur du capital prêtable de la société' (1826a, 2: 328; also 1814, 2: 116; 1817, 2: 127; 1819a, 2: 149). On the other hand, on the matter of capital-supply conditions he diverges in a major way from Smith - at least in a closed economy (Smith 1937 [1776]: 798-800) - when he denied that the interest rate might fall to zero. He rejects such an eventuality on the grounds that a fall in the rate reduces the motive to save: 'car plus les profits [des] capitaux diminuent, et plus diminuent aussi les motifs qui portent les hommes à l'épargne' (Say 1826a, 2: 337). A lower interest rate thus directs funds towards consumption purposes including expenditures on social projects, such opportunities becoming increasingly available in advanced economies:

Il est évident que l'homme qui pourrait épargner une somme sur ses revenus, la dépensera, si cette somme devient incapable d'être employée avec profit; car après tout elle renferme en elle une source de jouissances, et il y a des jouissances inépuisables, comme celles qui prennent leur source dans des actes de bienfaisance et de munificence publiques. C'est aussi dans les pays industrieux et économes que de tels actes sont les plus fréquens. 
It has been asserted that Say 'semble n'avoir jamais considéré l'interêt comme récompense pour l'attente individuelle ou l'épargne par le capitaliste (abstinence)' (Gootzeit 2003: 564). But this is surely not the case. In his Notes Say referred to accumulation as entailing 'une privation antérieure' (1819b, 1: 92), and similarly in the Lettres à M. Malthus: '[w]herever capital becomes too abundant, the interest which capitalists derive from it becomes too small to balance the privations which they impose upon themselves by their economy' (1821 [1820]: 40). The formulation of 1826 regarding the motive to save - reiterated, we shall see, in the Cours complet (below, p. 129) - is wholly consistent with these earlier allusions to a psychic cost requiring compensation.

\section{Entrepreneurial income}

The issues raised above are better clarified when we extend the discussion to entrepreneurship. We should settle first what the entrepreneurial function amounted to for Say. In the broadest terms it is to act as intermediary 'entre toutes les classes de producteurs et entre ceux-ci et les consommateurs' (1826a, 2: 275; also 1814, 2: 78; 1817, 2: 87; 1819a, 2: 105). But Say was more specific. Constraints on entrepreneurial supply assuring an appropriate return included scarce traits pertinent to attracting funds: 'il faut ... qu'il soit solvable, connu pour un homme intelligent et prudent, rempli d'ordre et de probité, et que, par la nature de ses relations, il soit à portée de se procurer l'usage des capitaux qu'il ne possède pas lui-même' (1826a, 2: 271-2; also 1814, 2: 74-5; 1817, 2: 84; 1819a, 2: 102). (The lower his creditworthiness the higher the element in the interest rate constituting 'une prime d'assurance'; above, p. 107.) Also relevant were scarce traits pertinent to business management proper both with respect to technological and marketing matters and also risk taking:

En second lieu, ce genre de travail exige des qualités morales dont la réunion n'est pas commune. Il veut du jugement, de la constance, la connaissance des hommes et des choses. Il s'agit d'apprécier convenablement l'importance de tel produit [1814: de telle production], le besoin qu'on en aura, les moyens de production [1814: de la procurer]; il s'agit de mettre en jeu quelquefois un grand nombre d'individus; il faut acheter ou faire acheter des matières premières, réunir des ouvriers, chercher des consommateurs, avoir un esprit d'ordre et d'économie; en un mot, le talent d'administrer. Il faut avoir une tête habituée au calcul, qui puisse comparer les frais de production avec la valeur que le produit aura lorsqu'il sera mis en vente. Dans [1814: . . d'administrer. Dans] le cours de tant d'opérations, il y a des obstacles à surmonter, des inquiétudes à vaincre, des malheurs à réparer, des expédiens à inventer. Les personnes chez qui les qualités nécessaires ne se trouvent pas réunies, font des entreprises avec peu de succès; ces entreprises ne se soutiennent 
pas, et leur travail ne tarde pas a être retiré de la circulation. Il n'y reste par conséquent que celui qui peut être continué avec succès, c'est-a-dire avec capacité. C'est de cette façon que la condition de la capacité borne le nombre de gens qui offrent le travail d'un entrepreneur.

(Say 1826a, 2: 272-3; also 1814, 2: 75; 1817, 2: 84-5; 1819a, 2: 102-3)

Say's understanding is that the Wealth of Nations traces the income of entrepreneur as 'organizer', together with the return to the capitalist proper or interest, to the use of capital goods in production, a practice that camouflages entrepreneurship as a separate factor (see Steiner 1998a: 206-7). The complaint appears in the early editions thus:

Smith (Liv. I, ch. 8) s'est jeté dans un grand embarras, faute d'avoir séparé les profits de l'entrepreneur d'industrie des profits de son capital. Il les confond sous le nom de profits du fonds (profits of stock); et, malgré sa profonde sagacité, il a grand'peine à démêler les causes qui influent sur leurs variations. Je le crois bien. Leur valeur se règle d'après des principes différens. Les profits de l'industrie dépendent du degré d'habileté, de la longueur des études nécessaires etc; [1819: du degré d'habilité, de l'activité, du jugement, etc., de l'entrepreneur;] les profits du capital dépendent de l'abondance ou de la rareté des capitaux, de la sûreté du placement, etc. ${ }^{16}$

(Say 1814, 2: 72-3n.; 1817, 2: 82n.; 1819a, 2: 100n.)

The 1826 version extends the complaint beyond Smith to "la plupart des économistes anglais' who sought to account for the income of entrepreneurial activity 'en les confondant avec les profits du fond capital' (1826a, 2: $235 n$.). Say rationalizes the 'confusion' in terms of legal practice:

D'après les lois anglaises, un capitaliste qui n'est-pas un simple prêteur touchant un intérêt fixe, mais qui a une part proportionelle dans les bénéfices et les pertes d'une entreprise, est considéré comme un associé gérant; ce qui explique la confusion que les économistes anglais font presque tous du profit de l'entrepreneur avec celui du capital.

Elsewhere he adds a linguistic rationalization:

Les anglais n'ont point de mot pour rendre celui d'entrepreneur d'industrie; ce qui les a peut-être empêchés de distinguer ... le service que rend le capital, du service que rend, par sa capacité et son talent, celui qui emploie le capital; d'où résulte ... de l'obscurité dans les démonstrations où ils cherchent à remonter à la source des profits. 


\section{Value, distribution and growth after 1823}

Thomas Tooke alone (Tooke 1824: 15) had fully appreciated Say's distinction between the profits of industry reflecting entrepreneurship and the profits of capital proper (Say 1826a, 2: 236n., 334n.).

The complaint is yet stronger - that the orthodox principle whereby the return on capital, after allowance for risk, tends to equality implicity excluded an entrepreneurial income. The standard view is expressed as follows:

Plusieurs économistes, sur ce fondement que les capitalistes donnent toujours la préférence, toutes choses d'ailleurs égales, aux emplois qui rapportent le plus, présument que les profits des capitaux s'égalisent par la concurrence, et que, si nous voyons des capitaux, engagés dans des entreprises périlleuses, rapporter de plus gros profits que d'autres, cette supériorité ne provient que d'une prime d'assurance suffisante pour compenser les pertes auxquelles le capital est exposé. Ils affirment en conséquence que, les pertes déduites, un capital ne rapporte pas plus qu'un autre.

(Say 1826a, 2: 331-2)

In reality, 'on s'aperçoit qu'ils ne suivent pas une marche si simple et si rigoureuse' (332). Two specific constraints generating differentials - and differentials pertinent to the entrepreneur - are noted. The first relates to nonmonetary advantages or disadvantages attached to various applications of capital (332-3); and the second to earnings differentials due to unequal entrepreneurial talent or 'capacités industrielles':

Smith, et après lui la plupart des économistes anglais, prétendent que le profit est en raison du capital d'une entreprise et non de l'industrie de son entrepreneur.... Ces diverses suppositions sont gratuites; [1826: Ces hypothèses ne suffisent pas pour fonder le principe;] car je peux supposer . . . deux manufactures dans un même endroit, travaillant un produit semblable, avec chacune 1,000 liv. sterl. de capital, mais conduites, l'une par un entrepreneur rempli d'intelligence, d'activité, d'économie, qui gagnera 150 liv. st. par an; et l'autre, conduite par un homme incapable et négligent, qui n'en gagnera que 50. La différence des profits, dans ce cas, ne viendra pas de la différence des capitaux qui seront pareils, mais bien de la différence des capacités industrielles.

$$
\text { (Say 1826a, 2: 333-4n.; 1819a, 2: 150-1) }
$$

This same sort of case is spelled out also in an important review of McCulloch's Discourse where Say objects to according Ricardo 'l'honneur d'avoir pleinement dévoilé les lois de la distribution des richesses', referring to the laws of income distribution, when the key player - the risk-taking entrepreneur - was omitted: 
Ne pourrait-on pas faire observer à M. M'Culloch que les points auxquels il attache une si haute importance ne sont pas les parties de la science les plus applicables et les plus utiles. Ce ne sont, convenons-en, ni la part du propriétaire foncier, ni la part du capitaliste, ni celle de l'ouvrier, sur quelques règles qu'il plaise à des théoriciens abstraits de les établir, qui exercent la plus notable influence sur la distribution des richesses. C'est la capacité des entrepreneurs d'industrie. Dans le même genre d'industrie, un entrepreneur qui a du jugement, de l'activité, de l'ordre et des connaissances, fait sa fortune, tandis qu'un autre, qui n'a pas les mêmes qualités, ou qui rencontre des circonstances trop contraires, se ruine.

(Say 1825: 712; emphasis added)

Most striking is Say's strong insistence on profit-rate uniformity, along with differential entrepreneurial returns:

Il convenait donc, ce me semble, de distinguer avec soin la capacité de l'entrepreneur d'industrie de la capacité du capitaliste, même lorsque ces deux capacités se trouvent réunies dans le même individu. La dernière, celle du capitaliste, ne peut éprouver que de faibles variations dans la part qu'elle obtient des valeurs produites. Celle de l'entrepreneur en éprouve de considérables. Voilà les vérités pratiques qui sont d'une grande utilité pour les particuliers.

This matter we shall take up again in Chapter 6 (below, p. 252).

In the Cours complet, Say again addressed the attribution to capital, by Smith and 'most British writers', of returns properly attributable to entrepreneurship, including both talent and also risk taking:

Adam Smith, et après lui la plupart des écrivains de sa nation, appellent les profits du capital, ce que j'appelle ici les profits de l'industrie; et ils disent en conséquence que les profits du capital sont plus ou moins forts, selon que la profession réclame plus ou moins de talents; selon qu'elle présente plus ou moins de risques. Il est évident que ces risques, ces pertes et ces profits regardent les capacités industrielles.

(Say 1843 [1828-9]: 331) ${ }^{17}$

M. Macculloch, professeur d'économie politique à l'université de Londres, dans un Commentaire qu'il a publié sur la Richesse des nations de Smith, en parlant du profit des capitaux, dit que c'est ce que reste à un entrepreneur après que son capital a étéétabli, et qu'il a été indemnisé de la peine qu'il a prise pour la surintendance de l'entreprise. On voit qu'il y a ici complication du service rendu par le capital et par le travail de l'entrepreneur. C'est seulement l'importance du gain qu'il doit à son travail et à son intelligence, qu'il s'agit d'évaluer ici: or ce gain n'est pas toujours proportionné à son capital. 


\section{Value, distribution and growth after 1823}

And a splendid statement will be found in the earlier Commentary on Storch, with particular emphasis on constraints on the supply of entrepreneurial services reflecting inter alia risk-taking ability:

Un entrepreneur d'industrie, c'est-à-dire, un agriculteur, un manufacturier, ou un négociant, est celui qui, à ses périls et risques, entreprend de fournir à la société les produits dont elle a besoin. Il apprécie les frais de production que nécessitera un produit; il préjuge la valeur qu'il aura étant terminée; il rassemble tous les éléments d'une entreprise, en compose l'administration et le régime. Comme il a perpétuellement des achats et des ventes à faire, des conventions de toutes sortes à conclure, il doit connaître les hommes et les affaires, évaluer les risques, prévoir les vicissitudes du commerce, l'influence de la paix, de la guerre et des mauvaises lois. La réunion des qualités et des talents qui sont nécessaires pour faire prospérer, et pour soutenir seulement une enterprise industrielle, établit une espèce de monopole en faveur des hommes qui sont en état de la concevoir, de la former et de la conduire. Ceux qui manquent de prudence et de lumières, ne font pas longtemps concurrence à ceux qui en sont pourvus. Telles sont les causes qui établissent, pour les entrepreneurs, des profits indépendents de leurs capitaux, et fort supérieurs au salaire d'un simple commis en chef, qui ne court aucun risque pour son compte, touche son traitement dans toutes les suppositions, et ne hasarde ni ses fonds, ni sa réputation en cas de mauvaise fortune.

(Say 1848 [1823]: 303)

Knight has noted that Say originally viewed the reward for risk taking as accruing to the capitalist, but in the Traité of 1819 transferred the function and its return to the entrepreneur (above, p. 21). We have encountered a passage appearing in all editions describing 'les qualités morales' which touches on the entrepreneur's ability to deal with risky situations (above, p. 110); yet there are modifications that perhaps point to a reattribution of the risk function in 1819 that do justify Knight's view.

In discussing the profit-rate structure in the earlier editions Say maintained that

les seuls motifs qui peuvent déterminer les possesseurs de capitaux pour tel emploi ou pour tel autre, ne peuvent être que le plus ou le moins de risque les perdre en tout ou en partie, ou bien le plus ou le moins de facilité d'en réaliser la valeur, et de retrouver la liberté de l'employer d'une autre façon.

(1814, 2: 117; 1817, 2: 128-9; emphasis added)

Even here 'les possesseurs de capitaux' might refer to entrepreneurs who are in possession of capital (whether their own or borrowed) rather than to 
capitalists; and indeed the relevant section sets out to investigate 'les causes des profits qu'on fait sur un capital ... soit qu'on l'ait emprunté, ou bien qu'on en soit le propriétaire' $(116 ; 127)$. The removal of the passage in 1819 and its reformulation (1819a, 2: 152) may reflect an attempt to avoid such ambiguity. But there are late statements that unambiguously attribute the risk function and its return to the entrepreneur: 'c'est l'entrepreneur, celui qui entreprend de créer pour son compte à son profit et à ses risques, un produit quelconque' (1826a, 1: 51n.); the section 'Des profits de l'entrepreneur d'industrie' itself opens in those terms:

Comme il est impossible de conduire une entreprise industrielle sans y employer un capital, les profits qu'y fait l'entrepreneur comprennent ordinairement les profits de son industrie et ceux de son capital. Une portion de ce capital lui appartient presque toujours en propre; une autre portion est fort souvent empruntée; dans tous les cas, que le capital soit emprunté ou non, le profit qui résulte du service qu'on en retire, est gagné par l'entrepreneur, puisqu'il a pris a son compte toutes les chances, bonnes et mauvaises, de la production.

(Say 1826a, 2: 269)

And we have seen that this is the stance taken in the Cours complet (above p. 113).

We return to the entrepreneurial function in its broadest terms, which is to act as intermediary between all 'classes of producers' and between these latter and consumers (above, p. 110). It is thus the entrepreneur - not the capitalist - who compares expected market prices with costs of production in determining output decisions: 'Il faut avoir une tête au calcul, qui puisse comparer les frais de production avec la valeur que le produit aura lorsqu'il sera mis en vente' (above, p. 110). This is not to weaken the long-run equilibrium process of the British tradition but to render it more precise - it is via the entrepreneur that outputs expand (or contract) as a result of the attraction (or expulsion) of productive services to relatively profitable (or from relatively unprofitable) industries. The end result is the same, that market prices tend to cost prices, with the difference that costs include a return to that 'fourth' factor, in consequence of the global scarcity of entrepreneurial services.

Here we note a particularly striking formulation in the Cours complet, where Say rejects the notion he attributes to the British writers that capital has a decision-making life of its own:

Les capitaux n'ont aucun motif de s'appliquer à certaines productions plutôt qu'à d'autres; ils n'ont ni goûts, ni volontés. Dire que les capitaux affluent là où ils trouvent de meilleurs profits, ne présente pas un sens plus juste que cette autre phrase: Les chevaux affluent dans les entreprises où ils mangent le plus d'avoine.

(Say 1843 [1828-9]: 332) 
Say has set up a straw-man, since it is surely true, on his own terms, that services are attracted into a sector by the entrepreneurial offer of relatively good terms to their suppliers; that is the case of labourers and landowners and it is difficult to see why it would not be true of capitalists. Indeed, were the passage taken literally there would be no scope for the emergence of a structure of interest rates, whereas Say had allowed compensation to the lender in the form of a 'prime d'assurance' which varies with the borrower's - that is, the entrepreneur's - creditworthiness and 'la sûreté de l'emploi' (above, note 13). Evidently, the capitalist lender has tastes and a will!

It must be noted, however, that the passage proceeds immediately to the assertion: 'Le fait est que l'on applique plus de capitaux aux entreprises qui donnent le plus de profits, mais que les profits plus ou moins grands qu'on tire de ces entreprises, sont ceux qui résultent de l'industrie de leurs entrepreneurs.' Here Say is assuming a case where the market-cost-price difference is actually due to entrepreneurial ability rather than the fortuitous play of market demand, suggesting a return to peculiar talent in some firm, that is to differential as distinct from global entrepreneurial scarcity. Even so, Say posits an inflow of capital, though he neglects to clarify whether, in consequence, the firm in question expands thereby whittling down the high entrepreneurial return, or whether that return is in the nature of a 'differential rent', rendered 'permanent' by competition on the part of capitalists. ${ }^{18}$

However we are to understand the above extract from the Cours complet, there are certainly other late statements allowing capital suppliers a degree of 'volonté'. One such is found after the discussion of constraints (relating to non-monetary characteristics and to entrepreneurship, above, p. 112) impeding the tendency to profit-rate uniformity. Here allowance is made for an active role by capitalists in the adjustment process which is said to be strongest in advanced economies, such as Britain and Holland:

Concluons que les profits qu'on peut tirer de l'emploi des capitaux, varient selon les lieux et les circonstances; et, malgré la difficulté qu'on éprouve à établir les lois générales qui déterminent ces profits divers, on peut présumer que toutes les circonstances qui contribuent à diminuer, pour chaque emploi, la quantité des capitaux qui se présentent, et à augmenter la quantité que réclament les besoins, tendent à élever les profits auxquels peut prétendre, pour sa quote-part, cet instrument de l'industrie. Dans les pays où l'on a plus généralement des habitudes économiques, comme en Angleterre, les capitaux étant plus communs, leurs profits, soumis à plus de concurrence, sont en général plus restreints. Quand l'ignorance, les préjugés, ou une timidité mal calculée, éloignent les capitaux des professions industrielles, ils s'y présentent en moins grande quantité et y font de plus gros profits. Avec des capacités industrielles égales, ils rendent bien plus en France qu'en Hollande, d'où non-seulement l'épargne les a rendus abondans, mais où nul préjugé 
ne les écarte des entreprises de commerce. On en peut juger par le taux de l'intérêt que l'on consent à payer dans l'un et l'autre pays.

(Say 1826a, 2: 335-6)

* * *

Say's retension of capital flows in the equilibration process is clear also from his observations regarding risk. Let us recall Smith's position that 'the ordinary rate of profit varies more or less with the certainty or uncertainty of the returns', which are borne by the borrowing entrepreneur (see note 16). But what is the nature of this uncertainty? That the context concerns the profit-rate structure strongly suggests 'measurable' risk consistent with the achievement of long-run equilibrium. And when Smith refers to novel 'projects' it is a temporary return to the 'projector' that concerned him, for '[w]hen the trade or practice becomes thoroughly established and well known, the competition reduces them to the level of other trades' (Smith 1937 [1776]: 115).

Did Say carry the analysis any further in this regard? We should emphasize first - drawing on the Table Analytique of the Traité under SERVICES PRODUCTIFS - the residual character of entrepreneurial income contrasting with the contractual character of the incomes received by regular service suppliers: 'S'il vend le service productif d'un fonds, celui qui l'achète est un entrepreneur. La valeur produite est alors au compte de l'entrepreneur, et l'indemnise, bien ou mal, de la valeur des services productifs qu'il a achetés et consommés pour produire' (Say 1817, 2: 481; 1819a, 2: 504). This formulation, though absent from the 1826 version, reflects Say's position throughout; and, considering the residual nature of his receipts, the entrepreneur carries the risk that sales proceeds fall short of contractual outgoings. Yet all our citations from the Traité (in all editions) relating to risk reflect constraints on entrepreneurial supply examined in the course of investigating competitive cost conditions. ${ }^{19}$ Moreover, Say adopts the Smithian perspective on new industries: 'Le même raisonnement', referring to the citation from Say given above in note 17 ,

explique aussi pourquoi les profits sont plus forts dans une industrie neuve que dans une industrie commune et courante, où la production et la consommation sont connues depuis nombre d'années. Les concurrens, dans le premier cas, sont écartés par l'incertitude du succès, et dans le second, ils sont attiré par la sûreté de l'emploi.

It is by restricting output - as with Smith and the classics - that the equilibrating adjustment for risk is brought about, the passage suggesting that Say like them intended measurable risk rather than Knightean uncertainty, which is indeed how Knight himself read him (see above, p. 21). The passage 
is removed from the reworked 1826 section 'Des profits des capitaux', but the principle itself reappears in wholly orthodox observations regarding the outcome of entrepreneurial innovation based on knowledge derived from the 'savant', where again long-run calculable costs are conspicuous:

Les sciences ne suffisent donc pas à l'avancement des arts: il faut de plus des expériences plus ou moins hasardeuses, dont le succès ne dédommage pas toujours de ce qu'elles ont coûté; lorsqu'elles réussissent, la concurrence ne tarde pas à modérer les bénéfices de l'entrepreneur; mais la société demeure en possession d'un produit nouveau, ou, ce qui revient exactement au même, d'un adoucissement sur le prix d'un produit ancien.

(1826a, 1: 59; also 1814, 1: 48; 1817, 1: 47-8; 1819a, 1: 48)

The entry under ENTREPRENEUR D'INDUSTRIE in the Epitome of 1826 is of considerable interest. It makes no mention of an innovative function and also seems to set at nought all the qualifications to the canonical uniformityof-returns principle; at the least it reconfirms the importance of "la concurrence' in eliminating surpluses:

ENTREPRENEURS D'INDUSTRIE. Ils concourent à la production en appliquant les connaissances acquises, le service des capitaux et celui des agens naturels, à la confection des produits auxquels les hommes attachent une valeur.... Ils ne sont capitalistes que lorsque le capital, ou une portion du capital dont ils se servent, leur appartient en propre; ils sont alors à la fois capitalistes et entrepreneurs.

Ce qui fait la difficulté de la tâche de l'entrepreneur, c'est de créer des produits qui vaillent autant ou plus que leur frais de production. Du moment qu'ils valent autant, la production est avantageuse; elle paie tous les services productifs, et par conséquent tous les profits, les revenus des producteurs. Si les produits valent plus que les frais de production, c'est un surcroît qui lui est ordinairement enlevé par la concurrence.

(Say 1826a, 3: 286-7)

'Costs' probably include a return to the (marginal) entrepreneur, any surplus in excess removed by competition, though Koolman is right to caution that 'it is not really clear whether Say regarded the entrepreneur as a separate factor of production' (Koolman 1971: 279).

\section{Rent}

We turn briefly to the treatment of rent. We recall that though at times Say in 1819 treats rent as a cost element on a par with wages and profits (interest), there are also indications of the differential-rent and zero-rent principles (see above, p. 56). Now in the chapter of the Traité devoted to 
'Des revenus territoriaux' (Book II, Chapter IX) Say explicitly spells out in 1826 the notion of a zero-rent, endogenously-determined, extensive margin, yielding differential rent on poorer lands, insisting on the principle as one established throughout his work:

Or, qui ne voit que si l'étendue des besoins de la société porte le prix du blé à un prix qui permet de cultiver les plus mauvais terrains, pourvu qu'on y trouve le salaire de ses peines et le profit de son capital, c'est l'étendue des besoins de la société et le prix qu'elle est en état de payer pour avoir du blé, qui permet qu'on trouve un profit foncier sur les terres meilleures ou mieux situées? C'est aussi le principe établi dans tout le cours de cet ouvrage-ci.

(1826a, 2: 357)

Say's claim that the principle was to be found throughout his work will be considered more fully in the concluding chapters. Material in the Cours complet is also relevant for, as we shall presently see, Say there traces the diminishing-returns principle to Adam Smith and claims appreciation of the phenomenon in the 1803 edition of the Traité (below, pp. 135-6). And we note here that in a letter to Mrs George Grote dated 11 May 1827, he mentions correcting the assertion that 'rent raises the price of wheat' in the 1826 edition (below, pp. 135-6).

\section{The earnings structure}

Cost analysis based on service-supply conditions in the case of unskilled labour presumes service mobility between alternative uses. As for the wage structure, Say's formal analysis in the Traité (Book II, Chapter 7, Section 1 'Des profits industriels en général') proceeds along Smithian lines, entailing monetary differentials which compensate for disutilities, regularity of employment, and human capital formation: '1. Ou les travaux de cette industrie entraînent des dangers, ou simplement des désagrémens; 2. Ou bien ils ne fournissent pas une occupation constante; 3 . Ou bien ils exigent un talent, une habileté, qui ne sont pas communs' (Say 1826a, 2: 257; also 1817, 2: 73; 1819a, 2: 91). Of course, appropriate supply constraints of each type of labour are responsible for the differentials:

Il n'y a pas une de ces causes qui ne tende à diminuer la quantité de travail mis en circulation, dans chaque genre, relativement à la quantité qu'on en demande, et par conséquent à élever le taux naturel de ses profits. $^{21}$

As for human capital, Say like Smith allows for interest on educational investment: 
le salaire du travail n'est plus un salaire seulement: c'est un salaire accru de l'intérêt [1814: plus l'intérêt] des avances que cette étude a exigées; cet intérêt est même supérieur à l'intérêt ordinaire, puisque le capital dont il est ici question est placé à fonds perdu, et ne subsiste pas au-delà de la vie de l'homme: c'est un intérêt viager.

(1826a, 2: 260; also 1814, 2: 67; 1817, 2: 76; 1819a, 2: 94-5)

In his expansion of the discussion in 1826 Say seems to object to the entire principle of compensatory wage differentials, particularly as elaborated by McCulloch in his Encyclopaedia Britannica account of the New School (McCulloch 1824), on the empirical grounds - 'la pratique' - that the most unpleasant jobs are usually found to be scarcely rewarded adequately:

dans la pratique les choses ne s'arrangent pas ainsi. Les hommes font rarement ce qu'ils veulent. Il y a des professions qui coûtent constamment la vie à ceux qui les exercent, comme celles de tailleur de grès, d'émouleur d'épingles, de vernisseur de faïences: il semble qu'il faudrait un énorme dédommagement pour un si grand sacrifice; cependant ces professions sont à peine plus lucratives que les autres.

(Say 1826a, 2: 263)

But here Say merely repeats what Smith had already said regarding characteristic overestimation of the likelihood of success: 'Le penchant de l'homme pour se flatter lui-même, pour croire que, s'il y a une chance heureuse, elle lui sera réservée, détermine vers certaines professions plus de travaux que les profits qu'on y peut faire ne sembleraient devoir en appeler' (264). And that he stood by the general principle of wage compensation is suggested by his further remark that it is the return to highly scarce 'talent' - referring to the exceptional artist, doctor and lawyer - that cannot 'en aucune manière' be absorbed by the Smithian principle. For this implies that for the most part the principle holds good:

Mais ce qui ne peut en aucune façon s'accommoder au système des compensations, ce sont les immenses disparités qu'établit dans les profits industriels et dans des carrières semblables, la différence des dispositions naturelles.... La rareté de certains talens en proportion des besoins qu'éprouve la société, fait qu'on paie les services productifs qui en émanent incomparablement plus cher que d'autres.

Much of relevance regarding this matter will be found in Book II, Chapter 1 'Des fondemens de la valeur des choses', where Say again insists in 1826 that the returns to highly specialized talent or land are demand determined: 
Un produit sera donc moins [sic] cher, selon que sa production réclamera non seulement plus de services productifs, mais des services productifs plus fortement rétribués. Il faudra, pour que ce produit puisse être créé, que ses consommateurs aient la volonté et le pouvoir d'y mettre le prix; autrement il ne sera pas produit.

But he also adds a crucial caveat - that service returns will be governed by the intensity of consumer demand in a particular industry only if service suppliers are in a position to insist on and obtain a bigher return:

Ce prix s'élèvera d'autant plus que les consommateurs sentiront plus vivement le besoin de jouir du produit, qu'ils auront plus de moyens de le payer, et que les marchands de services productifs seront dans une situation à exiger une rétribution plus forte. Le prix du produit sera dès-lors la somme nécessaire pour payer les services indispensables pour sa création.

Needless to say, service suppliers will be in no position to insist on 'une rétribution plus forte', whatever the pressure of consumer demand, if there is free entry into the industry; only assuming constraint on service supply - cases of specialist factors in short supply or severe institutional obstacles to entry into a profession - will service returns be entirely demand determined generating cases of 'pseudo-cost' such that market price coincides definitionally with natural (cost) price - or rather that natural price in that particular sector rises to equal market price.

Now Say, of course, did refer to varieties of service specificity relating to labour, capital and land, impeding in practice the tendency towards strict uniformity of service prices. For example, in Book II, Chapter 6 ('Quels genres de production paient plus largement les services productifs'), he considers in 1826 as in earlier editions cases where certain types of land, or fixed capital, cannot be turned towards a product for which there is high demand. Nonetheless, even here a tendency towards uniformity is reiterated, and we are left only with a mild qualification that service supplies cannot always be so adjusted to demand patterns as to assure uniform payment:

Il est vrai que les producteurs cherchent toujours à placer leurs services productifs dans les emplois où les profits sont meilleurs, et font ainsi baisser par la concurrence des prix que la demande tend à élever; mais leurs efforts ne peuvent pas toujours tellement proportionner les services aux besoins, qu'ils soient, dans tous les cas, également récompensés. Telle industrie est toujours rare dans un pays où le peuple n'y est pas propre; bien des capitaux se trouvent engagés de manière à ne pouvoir jamais concourir à une autre production que celle à laquelle ils ont été voués dans l'origine: la terre enfin peut se refuser à un genre de culture pour les produits de laquelle il y a beaucoup de demandeurs.

(Say 1826a, 2: 247-8; also 1814, 2: 55-6; 1817, 2: 65-6; 1819a, 2: 82-3; emphasis added) 


\section{Land-based limits to growth, the falling wage path and the stationary state}

In a posthumously published letter to Malthus of 24 February 1827 relating to the latter's Definitions in Political Economy, Say refers to qualifications made to the Law of Markets in the 1826 edition of the Traité. The statement is of high methodological interest:

je confesserai que ma doctrine des débouchés que vous avez combattue dans vos autres ouvrages, et dans celui-ci ... est en effet sujette à quelques restrictions. Je l'ai tellement senti que, dans la cinquième édition de mon Traité (tome Ier, page 194 et suivantes), qui a été publiée en trois volumes, à la fin de l'année dernière [1826], j'ai exposé cette restriction, quoique MM. Ricardo, Mill et MacCulloch aient adopté ma doctrine à cet égard, et que le ministère actuel de la GrandeBretagne [Huskisson] en ait fait la base de son nouveau système commercial; il vaut mieux s'attacher à l'investigation des faits et de leur enchaînement qu'à des syllogismes. Dans cette cinquième édition, j'ai en même temps combattu vivement les abstractions sur lesquelles on bâtit une économie politique idéale.

(Say 1843: 645; 1848: 504-5)

This so-called 'recantation' is sometimes read as a rejection of the Law of Markets interpreted as a denial of short-term limits to production (Lambert 1956). This view of the matter can be ruled out since such rejection is repeatedly made in all preceding editions of the Traité, not only in 1826. There would be nothing new here. Rather, in those 1826 passages to which he referred Malthus, Say was dealing with non-monetary limitations on secular expansion - despite his misleading allusion to a qualification relating to 'Des débouchés' (see further on this issue Chapter 5, note 9) - his criticisms of the 'abstract' writers alluding to their pure theory of a growing economy which he contrasts with his own 'practical' method:

On voudra savoir peut-être quel serait le terme d'une production croissante et où des produits, chaque jour plus considérables, s'échangeraient constamment les uns contre les autres; car enfin ce n'est que dans les quantités abstraites qu'il y a des progressions infinies, et dans la pratique la nature des choses met des bornes à tous les excès. Or, c'est l'économie politique pratique que nous étudions ici.

(Say 1826a, 1: 194-5)

Now Say proceeds to lay out what he perceived to be the so-called 'practical' limits to production - all in alleged opposition to the 'abstract' theorists - closing with a wholly 'canonical' exposition of the effect of increasingly scarce land in raising prospective labour cost of production 
above labour commanded, checking population growth and thus growth of demand, and bringing expansion to a halt:

Au-delà d'un certain point, les difficultés qui accompagnent la production, et qui sont en général surmontées par les services productifs, s'accroissent dans une proportion plus rapide, et ne tardent pas à surpasser la satisfaction qui peut résulter de l'usage qu'on fait du produit. Alors on peut bien créer une chose utile, mais son utilité ne vaut pas ce qu'elle coûte, et elle ne remplit pas la condition essentielle d'un produit, qui est d'égaler tout au moins en valeur ses frais de production. Quand on a obtenu d'un territoire toutes les denrées alimentaires qu'on en peut obtenir, si l'on fait venir de plus loin de nouvelle denrées alimentaires, leur production peut se trouver tellement dispendieuse que la chose procurée ne vaille pas ce qu'elle coûte. Si le travail de trente journées d'homme ne pouvait les nourrir que pendant vingt jours, il ne serait pas possible de se livrer à une semblable production; elle ne favoriserait pas le développement de nouveaux individus, qui par conséquent ne formeraient pas la demande de nouveaux vêtements, de nouvelles habitations, etc.

(Say 1826a, 1: 195-6)

To this Say adds a constraint on expansion imposed by increasing demand for leisure relative to goods, namely a labour constraint:

A la vérité, le nombre des consommateurs étant borné par les denrées alimentaires, leurs autres besoins peuvent se multiplier indéfiniment, et les produits capables de les satisfaire peuvent se multiplier de même et s'échanger entre eux. Ils peuvent se multiplier également pour former des accumulations et des capitaux. Toutefois les besoins devenant de moins en moins pressans, on conçoit que les consommateurs feraient graduellement moins de sacrifices pour les satisfaire; c'est-à-dire qu'il serait de plus en plus difficile de trouver dans le prix des produits une juste indemnité de leurs frais de production. Toujours est-il vrai que les produits se vendent d'autant mieux que les nations ont plus de besoins, et qu'elles peuvent offrir plus d'objets en échange; c'est-à-dire qu'elles sont plus généralement civilisées. ${ }^{22}$

By implication, in the absence of land or labour constraints - and other nonmonetary constraints to be discussed presently - the economy could expand ad infinitum, putting paid one would think to Smithian 'competition of capitals'.

Say's objection to concerns expressed by Sismondi regarding limits to growth points in the same direction. Those limits reflecting land scarcity - Say alludes to a future stationary state - are recognized, but did not justify restraints on the adoption of new technology on Sismondi's grounds of a lack of markets to absorb expanding output: 
Mais en fin, dira M. de Sismondi, il y a un terme à la possibilité de produire; et si les produits qui servent à loger, vêtir, instruire et amuser l'homme, peuvent se multiplier indéfiniment, et s'échanger les uns contre les autres, ceux qui le nourrissent et qui sont les plus indispensables, sont bornés par l'étendue du territoire; ou, du moins, à mesure que l'on est obligé de les faire venir de plus loin, on est obligé de les payer de plus en plus cher; dès lors, il arrive un point où les revenus qu'il est possible de gagner en produisant sont insuffisants pour mettre un plus haut prix aux denrées alimentaries, et une nouvelle extension de population devient alors impossible. J'en demeure d'accord; mais puisque la nature des choses toute seule met graduellement un terme à cette augmentation de production et de population qui est un bien, pourquoi accélérer ce moment? Pourquoi refuser aux nations la jouissance de tout le développement que leur permettent l'intelligence de l'homme et les progrès possibles des arts?

(Say 1848 [1824]: 256)

The theme is elaborated in a chapter of the Cours complet specifically devoted to 'Des bornes de production'. Again, in the absence of such constraints growth can proceed indefinitely with demand expanding along with supply, presumably at cost-covering prices:

Une conséquence nécessaire du chapitre qui précède ['Des causes qui ouvrent de plus ou moins grands débouchés à nos produits'] parait être qu'il n'existe aucune borne assignable aux productions qui peuvent naître de l'industrie et des capitaux d'un pays; en effet, si tous les produits peuvent s'acheter les uns par les autres, s'ils ne peuvent même s'acheter que de cette manière, il semble qu'on en peut conclure la possibilité qu'ils trouvent tous des acheteurs, quelle qu'en soit la quantité.

(1843 [1828-9]: 163)

But the growth process can be brought to a halt - or even prevented from commencing in the first place - as a result of a high demand for leisure rather than goods on the part of labour, a low level of technology, government interferences, all in addition to land scarcity. (It is surprising that no mention is made of a qualitative or quantitative paucity of 'entrepreneurship'.) All four constraints are phrased in terms of an inability of marginal producers to cover cost prices:

Maintenant, si nous voulons chercher quelles sont, dans chaque pays, les circonstances qui font que les produits, ou certains produits, y reviennent trop cher pour que la satisfaction qu'on en peut recueillir égale leurs frais de production, nous trouverons que cet effet tient à quatre causes, et que les débouchés sont d'autant plus faciles que l'on réussit mieux à se soustraire à leur influence. 
1. Ou la civilisation est trop retardée pour que les hommes éprouvent les besoins que les produits sont capables de satisfaire; 2. Ou l'art de produire est trop peu avancé pour que l'on produise à peu de frais; 3. Ou les vices de l'administration publique multiplient trop les frais de production; 4. Ou enfin, l'excès de la population ayant épuisé toutes les denrées qu'on peut se procurer à un prix modéré, la société ne peut s'en procurer davantage que par les frais qui en rendent les prix inaccessibles.

We turn now to the details of Say's analysis of 'les causes naturelles qui peuvent élever la valeur d'un produit à un taux qui exclut la possibilité de s'en servir et, par conséquent, d'en faire la demande', with particular reference to land scarcity:

Admettons que la population d'un pays, ses capitaux, son industrie, n'opposent aucune borne à sa production; il arrivera un point où son territoire en opposera une à sa consommation. Ce sera le point où les denrées alimentaires vaudront plus que le service qu'elles peuvent rendre; où la subsistance d'un jour coûtera plus que les produits d'un jour en quelque genre que ce soit.

That Say did not see stationariness as anything like an imminent prospect is scarcely surprising since his version of diminishing returns assumes an open economy and is thus stronger than anything typically found in Ricardo:

Quand l'agriculture aura été perfectionnée au point que le sol aura été amené à produire tout ce qu'il est capable de produire, il faudra tirer des aliments d'un pays étranger. On pourra encore en obtenir en donnant en échange quelque autre produit; mais comme dans un progrès que l'on suppose constant, après avoir tiré des denrées alimentaires du voisinage, il faudra les tirer d'un peu plus loin; leur production, par la voie du commerce, deviendra de plus en plus dispendieuse, jusqu'à ce que, même par cette voie, la quantité de denrées alimentaires que l'on pourra se procurer par le travail industriel d'un jour ne sera plus suffisante pour subsister un jour.

Say goes on to point out that at the maximum limit to food supply expansion of population and accordingly of demand in general cease; and that however slowly these tendencies might operate they were inevitable:

Il est évident qu'alors on ne produira plus la moindre augmentation de denrées alimentaires. Ces denrées étant celles que l'on peut le moins se dispenser de consommer, celles dont le besoin se renouvelle le plus promptement, ce sont elles qui mettent inévitablement un terme à la 
population, et par conséquent à toute espèce de consommation. On n’y arrive jamais tout à coup. Les difficultés de la production se multiplient graduellement, et la population se développe de plus en plus difficilement; mais on conçoit un terme qu'elle atteint, tantôt plus tôt, tantôt plus tard, selon la fécondité du pays, ses moyens de communication, soit au dedans, soit au dehors, selon la manière de vivre de la nation et son administration.

The discussion in Part VI 'Du nombre et de la condition des hommes' confirms what has just been said. We again find the land constraint acting on population growth: 'Qu'est-ce donc qui manque aux êtres organisés pour multiplier à ce point?', alluding to a sort of potential geometric growth rate. 'L'espace et l'aliment' is the answer. 'La difficulté n'est jamais pour eux de se multiplier, mais de se procurer les moyens de subsister'; when the restriction is removed '[c]ette puissance procréatrice s'est manifestée', at least when 'la multiplication de l'espèce humaine n'a pas été contrariée par les circonstances' (369). American experience, in contrast with that of Europe where 'l'accroissement est presque insensible, comparé à celui-là', provided the proof (369-70). And Say goes on to spell out decelerating population growth in consequence of decelerating food supply:

Il est évident . . . que la cause qui retient les populations dans les limites où nous les voyons, ou du moins qui les condamne à un accroissement toujours de plus en plus lent, est la borne de leurs moyens d'existence. La tendence des hommes à se reproduire et leurs moyens de se multiplier, sont pour ainsi dire infinis, mais leurs moyens de subsister sont finis, et il est incontestable qu'on ne saurait exister par delà.

Say cautions that the population relation turns not necessarily on food supplies but on national product as a whole allowance made for foreign trade (371-2). But this said, it is specifically the food constraint that is at issue in that 'les moyens qu'on a pour multiplier les denrées alimentaires, ont des bornes qu'on atteint plus tôt que celles qui existent pour les autres produits' (377). Here Say insists that it is not a question of a physical but of an economic limit, taking account of rising costs estimated in terms of a labour calculation:

On a prétendu que jusqu'à ce que la terre entière fût cultivée comme un jardin, elle pouvait fournir des subsistances à une population exubérante; mais on n'a pas fait attention que le prix auquel on peut acquérir les subsistances, n'est pas une consideration de moindre importance que l'aliment lui-même. S'il faut sacrifier deux journées de travail, ou la valeur de deux journées de travail, pour amener la nourriture d'un homme pendant un jour seulement, il est impossible qu'on ait recours à cet aliment, car il ne soutiendrait l'existence que pendant la moitié du temps nécessaire pour se le procurer. 
And this constraint, entailing rising food costs, comes into play notwithstanding allowance for foreign trade: 'On dit que le transport maritime peut amener le blé de fort loin avec peu de frais; mais cette assertion vague ne suffit pas; il s'agit ici de préciser le montant de ces frais.' Rising transport and related trade costs 'porte le blé des contrées les plus fécondes, à un prix inabordable pour la classe laborieuse'.

Most striking is the further assertion that not even technical change could be relied upon in the last resort since knowledge creation too is subject to diminishing return: 'Plus les arts utiles se perfectionnent, et plus de nouveaux perfectionnements deviennent difficiles; et lorsque cette marche se ralentit, les progrès de la population qui peuvent leur être attribués, se ralentissent à proportion' (379). The same evaluation will be found earlier in the Lettres à Malthus: 'in proportion as machines and accelerating methods become more numerous, the difficulty of still discovering new improvements is increased' (1821 [1820]: 70-1).

* * *

The consequence of increasing food costs is increasing misery in terms of clothing and lodging as well as food, implying a downward real wage trend:

la disette des denrées alimentaires entraîne pour la classe indigente, la disette de tous les autres produits nécessaires au maintien de la vie. Elle est obligée de consacrer à l'achat de sa nourriture une portion de ses profits qu'elle aurait, sans la cherté des vivres, consacrée à se vêtir plus chaudement, à se tenir plus proprement; et, bien qu'il soit vrai que ce soient généralement tous les moyens d'exister qui contribuent au maintien de la population, elle est presque toujours bornée, en effet, par la quantité de denrées alimentaires, que l'on peut se procurer au-dessous d'un certain prix. La disette de l'aliment le plus commun entrâne, pour le peuple, la privation de tous les autres produits.

(1843 [1828-9]: 378)

The falling real-wage path provides the logical explanation for decelerating population growth as with Ricardo and Malthus. But this is not consistently argued, since elsewhere in the Cours complet, as in the Traité, it is the subsistence path that is elaborated in the case of unskilled labour ('le simple manouvrier') with population adjusting to deviations above or below the subsistence level defined in standard terms as the level consistent with constant population, or that rate of pay 'nécessaire pour que chaque famille puisse élever jusqu'à l'âge adulte assez d'enfants pour remplacer le père et la mère' (333). Should the real wage rise slightly above that rate, 'les enfants se multiplient, et une offre plus grande se proportionne bientôt à une demande plus étendue'; in the opposite case: '[l]es familles les plus accablées d'enfants et d'infirmités dépérissent', resulting in reduced labour supply and upward 
adjustment of the wage. All in all, 'vous voyez par là ... qu'il est difficile que le prix du travail du simple manouvrier s'élève ou s'abaisse longtemps au-dessus ou au-dessous du taux nécessaire pour maintenir la classe au nombre dont on a besoin'. ${ }^{23}$ Say provides the standard qualification that the subsistence level varies according to cultural conditions; and adds that the close proximity of the real wage to the subsistence level applies in 'l'état naturel et ordinaire des choses' since disastrously large reductions in population would vary the wage far in excess of the subsistence level (334).

\section{The falling rate of interest}

We have seen that the downward real-wage trend, so central to the 'canonical' model, was by no means foreign to Say, though it remains true that he reasoned for the most part in terms of a constant long-run (subsistence) wage. To appreciate the fuller picture regarding the secular trends of the factor returns, we recall his concession in 1819 under pressure from Ricardo that the Smithian downward profit-rate trend in terms of increasing 'competition of capitals' had to be abandoned as in conflict with the Law of Markets and also his representation of Ricardo's explanation in terms of rising wage costs as inherent in, or consistent with, his own account once rid of Smith's error (see above, pp. 64-5).

One would expect that Say would spell out the concession and justify the claim fully in his later texts. Yet he does not do so. In the 1826 Traité he still argues in Smithian terms (above, p. 109). As for the Cours complet, there is nothing on the falling return on capital due to land scarcity in Part VI on population growth, while the chapter on 'des causes qui influent sur le taux de l'intérêt' (Part V, Chapter XVI) proceeds in terms general enough to be consistent with both the outdated and the Ricardian view: 'à mesure que ces capitaux se multiplient, leurs propriétaires en tirent un moindre intérêt' (Say 1843: 351). But it is competition of capitals he probably intended. Thus he stated the principle in question, albeit with a qualification:

On a cru, trop légèrement peut-être, que le bas intérêt était un signe assuré de la prospérité du commerce; on l'a cru, parce qu'on supposait qu'il indiquait toujours une grande abondance de capitaux. Mais le bas intérêt peut naître aussi bien de la rareté de la demande que de la quantité offerte des capitaux. On demande peu d'une chose dont on ne peut tirer qu'un médiocre parti.

Now the qualification is illustrated by special circumstances such as those of the late-Napoleonic years where ' $[u]$ ne résolution capricieuse, intempestive, peut alors changer toutes les données et déranger les combinaisons les plus méditées'. In normal circumstances the generalization held good and it is the Smithian rather than the Ricardian perspective that seems to be intended: 
c'est la quantité, la somme de toutes ces valeurs à prêter, sous quelque forme qu'elles s'offrent, qui composent les capitaux disponibles, et qui influent sur le taux de l'intérêt, toutes choses étant d'ailleurs égales, c'est-à-dire . . . qu'avec un état donné de l'industrie, l'intérêt baisse lorsque les valeurs capitales disponibles sont considérables, et hausse quand elles deviennent rares.

Say had apparently forgotten his admission of 1819 that the Smithian view is inconsistent with Law of Markets reasoning in its secular application.

Say did, however, retain the canonical position with respect to the negative effect exerted by a falling return on capital on the rate of accumulation: à mesure que ces capitaux se multiplient, leurs propriétaires en tirent un moindre intérêt, et par conséquent le motif qui porte à les accroître par des économies, devient de moins en moins puissant' (351). This reiterates what we found to be the case in the Traite of 1826 and even earlier (above, p. 109), with an important refinement rejecting the possibility of a zero rate of return: 'C'est ainsi qu'à mesure que les capitaux vont croissant, le motif qui porte à accumuler va en diminuant, et qu'il n'y a aucun degré assignable où le motif qui porte à accumuler devienne absolument nul' (352). Say makes no mention of the centrality of this savings-interest functional relation for the 'canonical' growth model.

\section{Summary: Say's representation of Ricardo}

Despite the common ground relating to cost pricing documented in the early sections of this chapter, Say continued in the Traité of 1826 to misread Ricardo on this matter - though by this time he had little excuse considering Ricardo's repeated efforts to restate his actual position against the readings of both Say and Malthus. I shall give some examples from material newly introduced in the last edition.

There is first the old canard that for Ricardo labour alone determines values to the exclusion of profits (not only of rent):

Les personnes qui pensent, avec David Ricardo et d'autres, que le travail (et non le concours du travail, des capitaux et des terres) est le seul élément des valeurs, peuvent substituer, dans cette démonstration, le mot travail aux services productifs; elle sera également concluante.

(Say 1826a, 2: 170n.)

Again: 'Si, généralement parlant, le prix des produits indemnise l'entrepreneur des frais qu'il fait pour le loyer de son capital, que devient le principe de David Ricardo, que le prix des choses ne contient rien qui représente les profits capitaux?' (330n.). A further instance appears in the discussion of 'la rétribution, qui constitue le profit du capital'. Here will be found the objections addressed in 1819 against Smith 'et ses partisans' 
regarding the reduction of capital to past labour, now turned against most of the English writers in general (above, p. 108); to this discussion Say added a new note in 1826: 'Voyez, dans l'Epitome qui termine cet ouvrage la démonstration rigoureuse de cette double production. Le capital employé paie les services rendus, et les services rendus produisent la valeur qui remplace le capital employé' (339n.), remarking in his text: 'Sur ce point, l'analyse de la plupart des écrivains anglais est singulièrement incomplète.'

Ricardo, it is true, sometimes wrote loosely of fixed capital as 'accumulated labour'; but he does so even when explaining cost differentials between products arising from the inclusion in the price of capital goods of profit on the machine-makers' investment (Ricardo 1951-73, 1: 34). His analysis belies Say's interpretation. More generally, there is Ricardo's insistence that though under specific technological conditions relative long-run (cost) prices will reflect relative labour inputs, the production cost of each product necessarily includes allowance for the return to capital at a uniform rate. But at least the first of the three notes cited above, by proposing a mere terminological substitution, does recognize that there is no substantive difference between systems on the cost-price proposition itself, Say remarking in his text: 'Il nous reste à connaître les bases qui déterminent leurs frais de production, c'est-à-dire qui déterminent le prix des services productifs' (Say 1826a, 2: 170, cited above, p. 89). That there is indeed nothing but a difference of terminology is fully confirmed by Say's explicitly stated agreement with Ricardo that prices can never in the long run - 'd'une manière suivie' - fall below cost:

lorsque quelques auteurs, comme David Ricardo, ont dit que c'étaient les frais de production qui réglaient la valeur des produits, ils ont eu raison en ce sens que jamais les produits ne sont vendus d'une manière suivie à un prix inférieur à leurs frais de production'.

Say, however, proceeds immediately to reject the view - the view that he attributed to Ricardo - that demand cannot influence value, on the grounds that this neglected the potential impact of an increase in final demand on the prices of the productive services themselves:

mais quand ils ont dit que la demande qu'on fait des produits n'influait pas sur leur valeur, ils ont eu, ce me semble, tort en ceci, que la demande influe sur la valeur des services productifs, et, en augmentant les frais de production, élève la valeur des produits sans pour cela qu'elle dépasse les frais de production.

Now the British writers - assuming mobility - predict an inflow of competing services from other sectors, the demand for whose products must have fallen, thus imposing a roof on the returns generated in the industry under 
consideration. And Say himself effectively does the same by introducing in the present context the caveat that service owners must be in a position to be able to claim a higher return, which would not be possible assuming free entry and exit (see above, p. 121). Conversely, if we introduce constraints on entry into the picture - as the British classics sometimes did - then both formulations will yield precisely the same 'pseudo-cost' outcome whereby market price coincides definitionally with 'cost' price. For we recall that where Ricardo treated specialized factors or factors in strictly limited supply, he arrived at all the results insisted on by Say in such cases. The most striking instance is his analysis of the extreme case of zero marginal product (at both margins) where land rent becomes entirely demand determined and yet can be said formally 'to enter into costs' in our sense of 'pseudo-costs' (above, p. 6). But beyond this, Ricardian analysis showed in a sophisticated manner how a change in the pattern of demand for final goods requiring differential factor ratios would act on the wage rate thereby changing the entire cost structure (above, p. 5). Say's attributions are unjustified.

Say's text amplifies the complaints with reference to McCulloch's treatment of training expenses in the Encyclopedia Britannica supplement (McCulloch 1825 [1823]), specifically his reduction of buman capital to pure labour costs (Say 1826a, 2: 172-3). Say himself followed Adam Smith in insisting on a wage differential which reflects training costs interpreted as including an implicit interest element (above, p. 120). But in this instance he did not extend his complaint to Ricardo.

We turn now to an assertion in Book II, Chapter 8 (336n.) that Ricardo had denied any effect of capital accumulation on the profit (interest) rate, considering the course of labour supply. Say bases his charge on a remark in the chapter 'Effects of accumulation on profits and interest': 'If the funds for the maintenance of labour were doubled, trebled, or quadrupled, there would not long be any difficulty in procuring the requisite number of hands, to be employed by those funds' (Ricardo 1951-73, 1: 289). But Say neglected the fact that elsewhere in his Principles Ricardo relaxed the assumption and, in an extended discussion of the matter in his chapter 'Taxes on raw produce', allowed explicitly for the effect of labour shortage on the return to capital (162-5). In any event, the objection is scarcely serious since Say himself expounded hard-line Malthusianism in the case of unskilled labour (above, p. 106).

$$
* * *
$$

Our next port of call is rent where we have found Say himself moving back and forth from its treatment as cost element and as differential surplus (above, p. 118). Here his continued misreading lies in attributing to Ricardo a denial of the endogenous, demand-determined margin in favour of an allegedly new foundation for rent - that the existence of poor land is the cause of rent on good land. ${ }^{25}$ Two insertions are made in 1826. First, 
[Ricardo] prétend que ce sont les frais qu'on est obligé de faire pour cultiver les plus mauvaises terres, qui font qu'on paie un fermage pour les meilleures, tandis que ce sont les besoins de la société qui font naître la demande des produits agricoles et en élèvent le prix asez haut pour que les fermiers trouvent du profit à payer au propriétaire le droit de cultiver sa terre.

(Say 1826a, 1: 6n.)

Similarly: 'Depuis les premières éditions de ce Traité, M. David Ricardo a cru trouver un nouveau fondement au profit des biens-fonds' (1826a, 2: 355). Say then proceeds to paraphrase that foundation involving differential land qualities:

Les unes excèdent beaucoup plus que les autres en qualité les plus mauvais terrains mis en culture; mais ce n'est jamais que la nécessité de cultiver ceux-ci pour satisfaire aux besoins de la société, qui procure un profit aux autres et permet d'en tirer un loyer. Il en déduit la conséquence que le profit foncier ne doit pas être compris dans les frais de production; qu'il ne fait pas, qu'il ne peut pas faire, le moins du monde, partie du prix de blé.

Now at this point we find Say's own formulation of the zero-rent principle entailing the endogenously determined margin and the claim that it had been established 'dans tout le cours de cet ouvrage-ci' (above, p. 119). But Say was, of course, actually expounding Ricardian doctrine; and there is every indication that he knew this well enough since he admitted that any differences between them were purely terminological, albeit that his own formulation was more revealing as to the 'immediate cause' at play:

Dire que ce sont les mauvaises terres qui sont la cause du profit que l'on fait sur les bonnes, c'est présenter la même idée d'une façon qui me semble moins heureuse; car le besoin qu'on éprouve d'une chose est une cause directe du prix que l'on consent à payer pour la posséder.

(357; emphasis added)

He goes even further by attaching a footnote recognizing that Ricardo in his rent chapter, 'montre très-bien que le profit foncier n'est pas la cause mais l'effet du besoin qu'on a de blé' (358n.) - as if this does not already emerge in the paraphrase of Ricardo's position itself with its references to 'les besoins de la société that raise the market price of corn above 'les frais de production qu'exigent les premiers terrains' (356). Again, the entire controversy which he blamed on Ricardo - was, Say repeated, nothing but a verbal matter despite McCulloch's insistence on a wholly novel contribution by Ricardo: 
On voit que la controverse élevée par Ricardo sur ce point, n'est guère autre chose qu'une dispute de mots; et je ne sais pas trop sur quel fondement Macculloch a pu dire que la publication de ces principes était la découverte la plus importante et la plus fondamentale dans la science de la distribution des richesses, et qu'elle formait une ère nouvelle et mémorable dans l'bistoire de l'économie politique.

He goes on to claim that while Ricardo had led him to make corrections in the monetary domain, this was not the case with respect to rent: 'il ne m'a fourni aucune amélioration à introduire dans ce qui a rapport aux profits fonciers' (358-9). Taken out of context, this might be read as a rejection of the rent doctrine, but such a reading is excluded by the explicit formulation of that doctrine on the previous page and also by recognition that any differences with Ricardo reflected only 'une dispute de mots'.

In a letter to Mrs George Grote of 11 May 1827, Say points to corrections made in the 1826 edition of earlier statements whereby rent raises the price of wheat, and in so doing he was at one with Ricardo in substance:

As for rent; j'avais en effet dit dans mes précédentes éditions, que le fermage augmentait le prix du blé; mais je me suis corrigé et je ne le dis pas dans cette 5e édition. Je dis seulement que ce ne sont pas les mauvais terrains qui font que les bons terrains fournissent un fermage (rent), mais que ce sont les besoins et les facultés de la société qui portent le prix du blé à un taux tel qu'il convient, outre les frais de la culture, de payer un fermage au propriétaire [Say 1826a, 2: 357-8]. Or, Ricardo dit la même chose, lorsqu'il dit [Ricardo 1951-73, 1: 77] rent is always the effect of the increasing wealth of the country. Mais si le blé monte à un prix tel que le cultivateur may afford to pay a rent, I may say that the price of corn contains a part of the rent, though rent is not the cause of $i$.

(Say 1848: 571)

We have seen, however, that Say had gone far in Ricardo's direction in earlier editions of the Traité too and in the 1819 Notes, though not consistently. In his later publications there is a rather more consistent recognition of the exclusion of rent from costs, at least at the extensive margin.

In two footnotes in the Traité of 1819 Say had objected that Ricardo neglected to apply the principle of endogeneity of the margin to the precious metals (above, p. 56). Now one (1819a, 2: 59n.) is removed in 1826, but the other (1819a, 1: 336n.) is reprinted with slight modifications. Here Say expounds, as his own alone, the diminishing-returns notion and resultant higher cost price upon demand expansion notwithstanding his recognition elsewhere in the same edition that this was also standard Ricardian doctrine: 
MM. Ricardo, Garnier, et quelques autres, soutiennent que les frais d'extraction déterminent seuls le prix des métaux, c'est-à-dire la quantité plus ou moins grande qu'on en offre en échange de toute autre chose. Ils méconnaissent conséquemment l'influence du besoin sur la valeur du métal. C'est contredire la mieux constatée de toutes les expériences, celle qui nous montre chaque jour que la valeur des choses s'accroît par la demande. . . Il n'est pas douteux que si, par des circonstances quelconques, le besoin qu'on a d'argent augmentait, son prix s'élèverait par rapport à celui de toutes les autres marchandises; on chercherait à exploiter des mines qu'on n'exploite pas en ce moment, parce que leur produit n'indemnise pas des frais d'extraction.

(Say 1826a, 2: 34-5n.)

Let us return to Say's allowance that Ricardo had in fact recognized rent to be the effect of the demand for corn (1826a, 2: 358n.; above, p. 132). This particular note proceeds to complain that Ricardo should have applied the same demand-oriented logic to the wage: 'les raisons qu'il en apporte peuvent servir à prouver contre lui que les autres frais de production, notamment les salaires du travail, ne sont pas davantage la cause, mais l'effet du prix courant des produits'. What could Say have intended? If it was the wages of unskilled labour, he had himself adopted subsistence-wage reasoning to explain their return. Here would be a fine case of the kettle calling the pot black. This certainly cannot be excluded (see above p. 131). But conceivably he was referring to what he considered to be one of the most essential of his contributions, that is the notion that all factor returns derive from the consumer: 'On ne peut concevoir aucune portion de la valeur de ce drap, qui n'ait servi à payer un revenu. Sa valeur tout entière y a été employée' (1826a, 2: 237-8; 1819a, 2: 73). The consumers' ability to purchase, Say had also elaborated in 1826, ultimately reflected their own production capacity, namely ownership of services:

Les facultés des consommateurs sont très-diverses; ils ne peuvent acquérir les produits dont ils ont envie qu'en offrant d'autres produits de leur propre création, ou plutôt de la création de leurs fonds productifs, qui se composent, on doit s'en souvenir, de la capacité industrielle des hommes, et des propriétés productives de leurs terres et de leurs capitaux; l'ensemble de ces fonds compose leur fortune.

$(1826 a, 2: 160)^{27}$

Again, in treating 'les motifs qui favorisent la demande des produits en général' - a reference to the discussion in 'Des débouchés' - Say in 1826 cites 'le nombre' and 'la richesse des consommateurs. En même temps que la civilisation multiplie leurs besoins, elle étend leurs facultés. Ils désirent plus vivement et paient mieux les services productifs par le moyen desquels on peut obtenir les produits' (1826a, 2: 255; cf. 1814, 2: 61; 1817, 2: 71; 1819a, 2: 89). 
These joint propositions - that the ultimate source of demand is to be found in production, and that all service returns are paid for by the consumer - constitute, of course, the circular-flow process repeatedly and brilliantly hammered home by Say. It is only regrettable that he presented this conception of the economic system as in conflict with the British view. Ricardo's explicit approval of Say's doctrine of services and derived demand was encountered above (p. 59). And when Ricardo - and this is true of Smith or J. S. Mill - wrote of costs as the 'cause' of price, he intended not to deny the role of demand or the proposition that factor prices are paid out of the final price. (As for the famous 'demand for commodities is not demand for labour', that relates not to this issue at all but to aggregate capital accumulation.) What was intended is the technical point that, assuming factor mobility between uses, market prices will tend to cost prices. This we know Say accepted, while all Say's results in cases of factor specificity or limitation of some sort are to be found in the canonical texts.

* * *

The Cours complet contains an extensive body of Ricardian theory relating to rent and confirmation of what we have found to be the case in the 1826 edition of the Traité - that Say admits a far greater degree of common ground than he leaves the casual reader to believe.

We start out with a formal attribution to Ricardo of the (Smithian) view that labour costs alone determine price - except for special cases of scarcity value:

David Ricardo .... adopte la doctrine de Smith sur ce point que (sauf dans les choses qu'il ne dépend pas de l'homme de multiplier à volonté, et auxquelles leur rareté sans remède, peut accidentellement faire mettre un très haut prix) les choses ne valent que la peine, le travail, qu'elles ont coûté.

(Say 1843: 102)

That for Ricardo land makes no contribution to costs resulted from the diminishing-returns principle; but proceeding to a summary of Ricardo's position Say himself allows that Ricardo did include a return to capital in (marginal) costs - that 'le prix suffit pour lui rembourser toutes ses autres avances, en y comprenant ses profits' - undermining his initial assertion to the contrary.

Now, we have seen that in the 1826 Traité, Say insisted that Ricardo had no claim to priority for the zero-rent margin where costs include wages and profits, since the diminishing-returns principle and differential rent had been adopted by Say himself very early on (above, p. 119). This same position is to be found in the Cours complet, with precedence accorded Smith the position championed in our day by Paul Samuelson (above, p. 10): 
Cette manière de décrire les faits est exacte; les choses se passent ainsi, et la remarque en a été faite dès longtemps. Adam Smith a consacré une partie considérable de son livre, à rechercher les cas où les terres rapportent plus ou moins de profits en commençant par celles qui n'en donnent point. Il trouve que le fermage (rent) varie non-seulement en raison de la fécondité de la terre, mais en raison de sa situation et des circonstances de la société [Note: Dès la première édition de mon Traité d'économie politique, publié en 1803, quatorze ans avant la première édition de l'ouvrage de Ricardo, j'avais assigné, d'après Smith, comme les causes du profit foncier (rent), la position du terrain, sa fécondité et la richesse du pays où il se trouve placé. Voyez 1 ère édit., tome II, page 307]; il n'y a donc rien de neuf dans l'observation de Ricardo.

(Say 1843 [1828-9]: 103)

In this light, we can well appreciate Say's complaint - again, as in 1826 regarding McCulloch's pretentious claims on behalf of the master - 'M. Macculloch a été jusqu'à dire que les recherches de David Ricardo ont été les plus importantes et les plus fondamentales qu'on ait faites dans la science de la distribution des richesses' - since the whole matter was old hat (104n.).

It must be emphasized now that Say - as in 1826 - shows that he was fully aware of the demand-determined margin in the Ricardian doctrine. Thus he cites Ricardo's summary statement [1951-73, 1: 77]:

If the high price of corn were the effect, and not the cause of rent, price would be proportionally influenced as rents were high or low, and rent would be a component part of price. But that corn which is produced by the greatest quantity of labour is the regulator of the price of corn; and rent does not and cannot enter in the least degree as a component part of its price.

He also cites the note Ricardo added in 1821: 'The clear understanding of this principle is, I am persuaded, of the utmost importance to the science of political economy'. And he expressly states that

ces paroles de l'estimable auteur ne sont qu'une autre manière d'exprimer cette vérité, que les besoins de la société sont la cause de la demande qu'on fait des produits quels qu'ils soient; et que la demande est cause du prix qu'on y met, pourvu que ce prix suffise pour payer les frais de production; car, si le prix courant ne s'élève pas assez pour payer les frais, le produit n'a pas lieu.

As in 1826, he insisted that this doctrine 'est exprimée partout dans mes ouvrages'. 
But Say - apparently wishing to occupy all positions - reiterated a series of complaints. First, he adds the invalid charge that Ricardo's correct vision of things in the present context conflicted with his alleged rejection elsewhere of the demand-supply mechanism in favour of cost pricing seen as an alternative:

On peut remarquer à ce sujet que Ricardo en reconnaissant implicitement que ce sont les besoins de la société, qui font monter le blé assez haut pour que son prix suffise à payer des travaux et des fermages plus élevés, dément une doctrine à laquelle il tient beaucoup: c'est que la proportion entre l'offre et la demande n'a point d'influence sur les prix, et que ce sont les seuls frais de production qui déterminent le prix courant.

Secondly, the notion of rent as 'effect' rather than 'cause' of price is represented as an 'abstraction' of no practical significance, a protestation that has a hollow ring to it given the concession that rent 'costs' do reflect 'des causes différentes' distinct from profits and wages costs:

Ces frais, du reste, quoique appartenant à des causes différentes, sont de même nature, quant au prix. La question de savoir s'ils font partie du prix, ou s'ils n'en font pas partie, quoiqu'on ne puisse pas se dispenser de les payer, est une question de pure abstraction, dont la seule solution n'influe en rien sur la pratique. Les conséquences qu'on en tire sont d'autres abstractions, comme, par exemple, que le prix n'est jamais déterminé par la nécessité de payer un fermage, mais par la nécessité de donner une certaine quantité de travail pour faire naître tout le blé dont les consommateurs ont besoin.

There is a third complexity that dissipates on close inspection. Despite his adherence to the Ricardian position, Say in our present context also insisted on the inclusion of rent within costs:

le profit foncier ou le fermage qui représente en général le profit foncier, fait partie des frais de production, et par conséquent du prix des choses de la même manière que tous les autres frais de production, ni plus ni moins.

But this representation turns out to be a mere formality and inconsequential, since it refers to the differential rent appearing on intra-marginal corn units: 
En tout pays, il se trouve des terres qui ont différents degrés de fertilité, depuis celles dont on ne saurait tirer aucun fermage, jusqu'à celles dont on paye le plus haut loyer. Le froment qui pousse sur les plus mauvaises ne se paye pas plus cher que celui qui pousse sur les meilleures, parce que les frais de production sont les mêmes pour le froment, quoiqu'ils se composent d'éléments différents. Le froment produit sur les mauvaises terres, coûte beaucoup en main d'œuvre, en engrais, etc. Le froment produit sur les bonnes, coûte moins en main d'œuvre et plus en fermage.

It has emerged then from the materials of 1828-9 thus far considered that Say not only accepted the diminishing-returns principle and the no-rent (extensive) margin, as in the 1826 Traité, but recognized the endogenous, demand-determined, component in Ricardo's account. To appreciate the significance of this allowance we need only compare the formulation in the earlier versions of the Traité (above, pp. 55-6). Yet it is frustratingly difficult to pin Say down, since subsequently in the Cours in discussing the cost of producing the precious metals (Part III, Chapter IX), Say returns to the charge that Ricardo neglected the endogenous margin:

Un auteur anglais dont l'opinion a beaucoup de poids en cette matière, et que, par conséquent, je ne peux pas passer sous silence, David Ricardo, dit à l'occasion de cette doctrine, que l'étendue de la demande n'exerce aucune influence sur la valeur de l'argent ni d'aucune autre denrée; que leur valeur, à toutes, est irrévocablement déterminée par leurs frais de production; qu'on les obtient toutes pour le prix qu'elles coûtent à produire, parce que si l'une d'elles valait sur le marché plus qu'elle ne coûte à produire, la concurrence des producteurs qui se porteraient de préférence vers ce genre de production, en ramènerait le prix au niveau des frais.

Yet he makes up for this misrepresentation by immediately conceding that 'Ricardo a raison' on the cost determination of price, adding for his own part 'et je crois n'avoir pas tort', intending by this the demand determination of the cost margin, with land rent entering as cost in the case of intra-marginal land or mines:

On ne paye pas un produit, fût-ce le métal d'argent, au-delà de ses frais de production; mais la demande qu'on peut en faire quand les nations parviennent à une situation plus prospère, permettant d'élever le prix qu'on peut y consacrer, les producteurs de cette marchandise peuvent exploiter des mines plus dispendieuses, soit en raison des difficultés de l'exploitation, soit à cause des prétentions plus élevées des propriétaires 
du fonds. . . . Les plus fécondes se louent plus cher; ou si le propriétaire lui-même les fait exploiter, il en tire un profit foncier supérieur à celui que tire tel autre propriétaire.

On substance, we conclude, Say is in accord with Ricardo despite efforts to differentiate his product, half-hearted efforts considering the accommodating remarks relating to what Ricardo in fact appreciated if only implicitly, and what even his followers must sooner or later come to appreciate:

Il est impossible que les partisans de l'opinion de Ricardo nient cet effet qui se manifeste dans beaucoup d'autres produits. Entre personnes qui entendent bien l'économie politique, il ne peut y avoir que des dissentiments apparents; et en s'expliquant sur le sens que chacun a donné aux expressions, il est impossible que l'on ne soit pas tôt ou tard du même avis.

$(188 n$.

The importance to Say of the diminishing-returns principle is such that he returns to the same arguments yet again in the fifth part of the Cours (Chapter $\mathrm{XX}$ ). Here he once more rejects Ricardo's belief repeated by his followers he writes politely of Ricardo - that Adam Smith had neglected the principle:

Quelques écrivains anglais, marchant à la suite de David Ricardo, mais dont il n'est pas permis de méconnaître les services et les talents, ont cru que Smith n'avait pas assigné les véritables causes du profit foncier; qu'il n'avait pas trouvé les lois qui en déterminent le montant, et qu'il n'avait pas connu de quelle manière il est affecté par les progrès de la société.

Ricardo had added nothing: 'N'est-ce pas convenir de ce qui est établi dans Adam Smith et dans mes ouvrages? Quelle découverte nouvelle y a-t-il là dedans?'

Now Say returns to the claim that the Ricardian version - at least as expounded by McCulloch in his notes to Smith's Wealth of Nations (McCulloch 1828) - ascribed rent to the circumstance of 'l'inégalité des frais' rather than to the true cause (the pressure of demand), and unnecessarily restricted the principle to land only. It comes then as a surprise to find in this very context Say allowing that even McCulloch in fact recognized the play of the demand element:

C'est si bien là la cause qui fait monter le prix du blé, que M. Macculloch [1828: 105] lui-même dit en propres termes que la valeur du blé tend à monter par L'AUGMENTATION DE LA DEMANDE qui résulte de l'augmentation de la population. ... N'est-ce pas convenir que le prix qui fournit un profit au propriétaire foncier, provient de l'étendue de la demande? 
As for Ricardo, he too had understood the truth of the matter:

David Ricardo convient de même que c'est l'augmentation de la population, c'est-à-dire de la somme des besoins, qui élève assez le prix du blé pour qu'un fermier trouve son compte à payer un fermage. Il en conclut que 'le blé a une valeur, non par la raison qu'on est obligé de payer un fermage, mais qu'on paye un fermage parce que le blé a de la valeur' [1951-73, 1: 74].

Say even agreed with the Ricardian deduction that were landlords to relinquish their rent the price of corn would not decline:

'Quand même', poursuit Ricardo, 'les propriétaires abandonneraient la totalité de leurs fermages, le prix du blé ne baisserait pas'. Je le crois bien, puisque c'est l'étendue du besoin qui est la cause première de la valeur, et que l'abandon que feraient les propriétaires ne diminuerait en rien l'étendue du besoin.

His only objection was to the expression 'rent does not enter into price', since this after all is not the case on intra-marginal land:

Ricardo veut prouver, contrairement à Smith, que le fermage ou profit foncier n'est point une partie constitutive du prix des denrées: mais ce qu'il dit ne le prouve pas. Si dans un hectolitre de 18 francs il y a 3 francs pour le propriétaire, les 3 francs sont bien une partie constitutive du prix, quoique ces 3 francs fussent payés à un autre, dans le cas où le propriétaire n'en ferait pas son profit.

Say had one objection to make regarding Smith. Though Smith had expounded the valid distinction between rent as effect not cause of price long before Ricardo, he erred elsewhere in the Wealth of Nations where he identified rent and other costs. He erred because in all cases it is demand that dictates what prices must be to permit the necessary service payments to be met. In this context Say refers to rent payments as the return to 'monopoly' referring to the scarcity property of land, as was standard early nineteenthcentury practice:

Au surplus, Adam Smith avait dit longtemps avant David Ricardo, que le fermage est l'effet et non la cause de la valeur du blé (Liv.I, chap.2). Il est vrai qu'il dit en même temps qu'il n'en est pas de même des profits du travail et du capital, qui sont la cause du prix et n'en sont pas l'effet. Je crois que, dans ce dernier cas, Smith est lui-même dans l'erreur; ce sont, de même que pour le blé, les besoins de la société qui font le prix des produits quels qu'ils soient, et qui permettent à un entrepreneur de 
payer les profits du travail et du capital, et quelquefois même un profit pour le monopole, quand le monopole est nécessaire pour que le produit soit créé, comme c'est le cas relativement aux produits de la terre.

Say, even in the present context, was prone to forget his concession regarding McCulloch's recognition of the demand-determined margin in corn production. And he cites Malthus's evidence in the Third report on emigration from the United Kingdom for the true perspective, whereby it is the level of demand, by raising price and permitting inferior land to be cultivated, which is the cause of rent, not the cultivation of inferior land as such:

Il faut rendre à $\mathrm{M}$. Malthus la justice de dire qu'il a senti le défaut de cette doctrine, et qu'il a précisé son opinion dans une réponse consignée dans une enquête parlementaire. Sur la question qu'on lui adressait pour savoir si la mise en culture de nouvelles terres n'élèverait pas le loyer des anciennes, il a répondu: 'Le renchérissement des produits comparativement avec les frais de production, qui est la cause de l'élévation du fermage, a lieu d'abord, et ensuite vient la culture des mauvaises terres; mais ce n'est pas la culture des mauvaises terres qui fait renchérir les fermages: telle est la doctrine que j'ai établie dans mes écrits, et c'est, je crois, la véritable: d'autres en ont soutenu une autre' [Malthus 1827a: 321].

To this he adds a note further reducing any claims that might be made for Ricardo as 'discoverer': 'M. Macculloch qui avait fait honneur de cette prétendue découverte a David Ricardo, l'a attribuée ensuite à $\mathrm{M}$. Edward West; et finalement a reconnu que c'est M. James Anderson qui l'a donnée au monde: ce sont ses expressions.'

Say's commendation of Malthus, rather than Ricardo, is ironic. For in Malthus's formal work on corn pricing he failed to treat the demand dimension adequately, writing as if supply governed demand, which fact had provided Ricardo with an opportunity to instruct him on the elements of what effectively amounts to Marshallian price theory (above, p. 12). Yet more ironic is the fact that Say himself, as in his earlier writings (above, p. 43), adopts the population-based viewpoint: 'On verra plus loin, lorsque je traiterai de la population [368-74], que les hommes aussi se multiplient indéfiniment, lorsqu'on leur fournit des moyens de subsister' (132n.); or again: 'les hommes naissent partout où ils peuvent obtenir les choses capables de les faire subsister' (160). On these grounds he commended corn as the best measure of value conceivable:

Il est bien vrai que le pain étant moins cher, le cercle des consommateurs de blé a dû s'étendre; mais de toute manière le nombre des consommateurs n'a pas pu s'étendre au-delà de ce que la quantité de blé, 
quelle qu'elle fût, a pu nourrir. Si les consommateurs ont augmenté en nombre, ce n'est qu'autant que l'agriculture a produit davantage. . . . Le consommateur a pu alors payer le blé le même prix qu'auparavant.

There remains one further matter, Say's mockery of the intensive margin, a concept which he implies at one point was due to McCulloch engaging in a sort of rearguard or defensive action:

Le même auteur, s'apercevant sans doute du ridicule qu'il peut y avoir à assigner les mauvaises terres comme la cause qui fait que les bonnes donnent du profit, ne voit là dedans qu'une petite chicane (a petty cavil), et il exprime la même idée par cette autre formule: sur le capital tout entier employé à l'agriculture, il y a une portion qui ne donne aucun profit foncier [1828: 113], et c'est là que se trouve le véritable fondement du profit foncier $(r e n t)$. Mais cette nouvelle formule est susceptible de la même objection. Est-ce qu'une absence de profit dans un cas peut être une cause de profit dans un autre?

But a little earlier we find a mysterious footnote addressed at Ricardo which turns out to refer to just this matter, which Say dismisses as of 'no importance':

David Ricardo, dans la $3^{\text {ème } e ́ d i t i o n ~ d e ~ s o n ~ l i v r e, ~ a ~ l ' a i r ~ d ' e ̂ t r e ~ f a ̂ c h e ́ ~ d e ~}$ ce que je ne me suis pas arrêté sur ce qu'il appelle une importante doctrine. C'est précisément parce que je ne la crois pas importante que je n'en ai rien dit. Rien ne me paraît important que ce qui est utile et applicable.

Say's allusion is to Ricardo's complaint that

[i]n no part of his notes has he refuted, or even noticed that important doctrine. By his note to page 182 of the second volume of the French edition [Say 1819b, 2: 182], he does not appear to be aware that it has even been advanced.

(Cited above, p. 53) ${ }^{28}$

It is regrettable that Say failed to face up properly to Ricardo's criticism and admit the significance of the intensive margin. But by the late 1820s he had, we have shown, committed himself to the stronger version of the doctrine - the absence of rent at the extensive margin - abandoning apparently all his earlier empirically based objections. That the existence of zero-rent land areas is now taken for granted can be seen in Part V, Chapter XIX of the Cours complet: 
En tout pays, il y a des terres que leurs propriétaires seuls peuvent faire valoir et dont aucun fermier ne voudrait offrir un loyer. Par quelle raison? Parce que leur produit peut bien payer la peine et les avances, mais ne peut rien payer pour le profit du sol. 


\section{On 'riches' \\ Real income and its measurement}

\section{Introduction}

The Say-Ricardo debate regarding 'riches' has been touched on tangentially in our discussion of the positive theory of value in Chapters 2 and 3. Much of the debate, we shall now show, concerned measurement of the flow of real income, and this from an economy-wide perspective. ${ }^{1}$ On this welfare issue, we find the protagonists to be in agreement. The story is a comedy of errors, though in retrospect easy to appreciate. Say's vehement insistence against Ricardo on riches as a value rather than a utility entity turns out to relate specifically to valuation of a stock of goods; his main concern, however, was the increased flow of real income and its utility counterpart resulting from output-expanding technology and here there is clear accord with the canonical position. For the notion of riches as entailing an exchange relation relates to the purchasing power of the nominal incomes of service suppliers, 'riches' rising with reductions in cost prices due to new methods. This wholly orthodox 'solution' is represented in the Traité as a major novelty:

Nous trouvons là-dedans l'explication et la preuve d'une vérité qu'on ne sentait que bien confusément, et qui même était contestée par plusieurs sectes et par un grand nombre d'écrivains: c'est qu'un pays est d'autant plus riche et mieux pourvu, que le prix des denrées y baisse davantage.

(Say 1814, 2: 35; 1817, 2: 42-3; 1819a, 2: 44; 1826a, 2: 188)

As expressed in the Cours complet:

Cette démonstration, poussée à la dernière évidence par l'étude des principes fondamentaux, a donné la clef d'une proposition qui semblait paradoxale: on ne pouvait pas jusque-là concilier ces deux idées également vraies, que la valeur des choses qu'on possède constitue le degré de richesse qui réside en elles; et, en même temps, qu'un peuple est d'autant plus riche, que les produits y sont à meilleur marché. En effet, nous serions tous infiniment riches si tous les objets que nous pouvons désirer ne coûtaient pas plus que l'air que nous respirons; et notre indigence 
serait extrême, si les mêmes objets coûtaient infiniment cher, si nous n'avions aucun moyen d'atteindre à leur prix.

(Say 1843 [1828-9]: 550-1)

The theme and the claim to novelty will be found repeated over and again throughout Say's writings.

\section{The early Say-Ricardo exchange 1815}

The exchange commences with Ricardo's objections to the representation both of 'riches' and 'value' expressed in the Catéchisme d'économie politique (1815), a work Ricardo found to be in general 'excellent' with '[a]ll the grand principles ... perspicuously and forcibly laid down' (letter dated 18 August 1815; Ricardo 1951-73, 6: 247). As for 'riches', Ricardo disputed Say's formulation which seemed to deny that '[r]iches are measured by the quantity of valuables which a man possesses':

Riches are valuable only as they can procure us enjoyments. That man is most rich, and has most valuables, who can procure in exchange for his commodities, not those things which he himself or the world generally consider as most desirable, because they may possibly be procured at little cost, but those things which are of difficult production, which is always the foundation of great value. It appears to me therefore incorrect to say as you do ... that that man is superlatively rich, although he has few valuables, who can procure easily or for nothing those things which he wishes to consume. He may only wish to consume bread and water and may be able to procure no more. He cannot be so rich as his neighbour who has abundance of valuables which he can exchange for all the luxuries of life, which it is his desire to consume. Riches are measured by the quantity of valuables which a man possesses, not by the moderation of his wants.

(Ricardo 1951-73, 6: 248)

The expression 'quantity of valuables' is an unfortunate source of confusion since evidently command over real goods is the object of the exercise; indeed, as we shall see, Ricardo in the Principles perceives riches explicitly in terms of the utility counterpart of those real goods.

Say maintained in his response that he had been misread - and implies that he was at one with Ricardo - insisting as he did on the relativity property of value and therefore of riches; accordingly, riches are higher the lower the cost prices of desired commodities in the sense that purchasing power over real goods is thereby raised:

Je ne dis pas comme Epictète [Epicurus] que la richesse est d'autant plus grande que les désirs sont plus moderés, mais d'autant plus grande 
que les choses qu'on veut avoir sont moins chères. En un mot toute valeur est relative, et la richesse n'étant que de la valeur, est relative aussi.

(Say, in Ricardo 1951-73, 6: 271-2)

Although Say insisted on riches in value terms, real income is intended, the relativity property in effect referring to the ratio between money incomes and money prices.

The alternative version of the letter, dated 2 December 1815 (above, p. 28 and note), points out rightly that Ricardo himself seemed to adopt a notion of riches in value terms by his expression 'quantity of valuables', but since this was only in so far as 'they can procure as enjoyments', there was no discord: 'quand vous ajoutez: "Riches are valuable only as they can procure us enjoyments; and the man is most rich who has most valuables", vous tenez exactement le même langage que moi' (273). In the limiting case where all goods are free, riches could only be perceived in real terms. In the more realistic case - and in this context we find a hint of an incremental notion - values enter the picture to complicate matters; nonetheless, the main proposition holds good that command over goods rises as production costs and thus values tend downwards:

Je m'aperçois que je me suis encore mal exprimé dans un autre endroit (page 95), en disant que: 'le comble de la richesse, quelque peu de valeurs qu'on possédât, serait de pouvoir se procurer pour rien tous les objets qu'on voudrait consommer.' Je n'ai point voulu dire comme les stöiciens, et comme vous m'en accusez, qu'on est d'autant plus riche qu'on a moins de désirs, mais d'autant plus, qu'on peut acquérir à meilleur marché les choses qu'on désire, quelles qu'elles soient, c'est-à-dire des maisons, des domestiques, des chevaux, si on les désire; ce qui arriverait, en effet, dans la supposition où les difficulties des frais de production se réduiraient à peu de chose ou à rien. Cette supposition est inadmissible dans son excès, je le sais; mais, ce qui ne l'est pas, ce sont les différents degrés de bon marché (cheapness) qui s'éloignent ou se rapprochent plus ou moins du bon marché absolu.

(Say, in Ricardo 1951-73, 6: 274)

\section{'Riches' as real-income flow: the case elaborated}

We take up in this section the renewed Say-Ricardo debate after the appearance of Ricardo's Principles in 1817, with its confirmation that riches entailed a utility concept:

riches do not depend on value. A man is rich or poor, according to the abundance of necessaries and luxuries which he can command; and whether the exchangeable value of these for money, for corn, or for labour, be high or low, they will equally contribute to the enjoyment of their possessor.

(Ricardo 1951-73, 1: 275-6) 
By confusing value and riches, Ricardo complained, Lauderdale (1804) had been led to assert

that by diminishing the quantity of commodities, that is to say, of the necessaries, conveniences, and enjoyments of human life, riches may be increased. If value were the measure of riches this could not be denied, because by scarcity the value of commodities is raised; but if Adam Smith be correct, if riches consist in necessaries and enjoyments, then they cannot be increased by a diminution of quantity.

As for Say, he appeared to Ricardo inconsistent by conceiving riches sometimes in product and sometimes in value terms.

As a conspicuous example of the value conception, Say in the Catéchisme had argued in the case of a technical change halving the price of a commodity, that though the 'riches of a society [are] composed of the sum total of the values which it possessed', the posited fall in value of a product does not diminish the mass of its riches as might appear to be the case:

the sum of the society's riches will not fall on that account. Two pair of stockings are produced instead of one; and two pair at three francs, are equally valuable with one pair at six francs. The income of the society remains the same, because the manufacturer has gained as much on two pair at three francs, as he gained on one pair at six francs.

(Say 1815: 99, translated by Ricardo 1951-73, 1: 287-8n.)

In Ricardo's estimate, Say erred in defining riches in value terms, but so far his argument was 'at least consistent'. This could not be said of the further 'inference' - this is the inference we have touched on earlier (above, pp. 145-6) - that

when the income remains the same, and productions fall in price, the society is really enriched. If the same fall took place in all commodities at the same time, which is not absolutely impossible, the society by procuring at half their former price, all the objects of its consumption, without having lost any portion of its income, would really be twice as rich as before, and could purchase twice the quantity of goods.

(288n.)

Here Ricardo points out correctly that Say estimated riches 'by the abundance of commodities contributing to human enjoyments', which was his own position. There was also a conflict between the Catéchisme and the Traité. For the former has it 'that a man is infinitely rich without valuables, if he can for nothing obtain all the objects he desires', but in the Traité (Say 1814, 2: 2) we are told 'that riches consist, not in the product itself, for it is not riches if it have not value, but in its value' (Ricardo 1951-73, 1: 288n.). 
The Notes on Ricardo's Principles carries the story forward from Say's perspective. Here we encounter a detour, for Say once more insists on riches in value terms, only to end up - as in the 1815 correspondence - with Ricardo's real income or utility conception.

At the outset Say describes Smith's contrast between value in use and value in exchange with the focus specifically on the latter as a fundamental scientific advance, but a matter Ricardo in his first chapter had neglected to emphasize:

La distinction que fait ici M. Ricardo [1951-73, 1: 11], d'après Adam Smith, entre la valeur d'utilité et la valeur échangeable, est fondamentale en économie politique. Peut-être aurait-il dû remarquer que cette dernière, la valeur échangeable, est celle dont Smith s'est exclusivement occupé dans tout son ouvrage, et que c'est en cela que consiste le grand pas qu'il a fait faire à l'économie politique, à la science de toutes peut-être, qui influe le plus directement sur le sort des hommes.

(Say 1819b, 1: 2)

(This sort of formulation lends support to Dupuit's contention (above, p. 100) that Say sought to displace value in use by value in exchange.) More specifically, exchange value - strangely he calls it an 'abstract quality' allowed the quantification of riches:

En effet, la Valeur, cette qualité abstraite par laquelle les choses deviennent des Richesses, ou des portions de richesses, était une qualité vague et arbitraire que chacun élevait ou abaissait à son gré selon l'estime que chacun faisait de sa chose; mais du moment qu'on a remarqé qu'il fallait que cette valeur fût reconnue et avouée pour qu'elle devînt une richesse réelle, la science a eu dès lors une base fixe: La valeur courante ou échangeable des choses, ce qu'on appelle leur prix courant, lorsque l'évaluation en est faite dans la monnaie du pays. En raisonnant sur cette valeur, sur ce qui la crée, sur ce qui l'altère, on n'a plus raisonné sur des abstractions, pas plus que deux héritiers, après avoir fait l'inventaire d'une succession, ne se partagent des abstractions.

But, surprisingly, Say immediately deflects attention from riches evaluated at exchange values 'dans la monnaie du pays', by pointing to the real products that exist prior to and sometimes independent of exchange and objecting to 'the majority' of writers who misused Smith's insight:

cette nécessité de fixer la valeur des choses par la valeur qu'on peut obtenir en retour de ces mêmes choses, dans l'échange qu'on voudrait en 
faire, a détourné la plupart des écrivains du véritable objet des recherches économiques.... [C] ]e n'est point dans les échanges mêmes que consiste la production ou la consommation des richesses. Il y a beaucoup de richesses produites, et même distribuées sans échange effectif.

We are already close here to a notion of riches independently of exchange value - Ricardo's view. Say apparently wanted to cover all positions. In fact, the main conclusion at this juncture is that exchanges need not actually occur for the quantification of riches in value terms:

La valeur échangeable d'une chose, même lorsque l'échange ne s'effectue pas, sa valeur vénale, c'est-à-dire la valeur qu'elle aurait dans le cas où l'on jugerait à propos de la vendre, suffit donc, même sans qu'aucune vente ait lieu, pour constituer la richesse. C'est ainsi qu'un négociant connaît sa richesse par l'inventaire qu'il fait de son fonds, même sans avoir l'intention de le vendre.

Later in his Notes Say adds the qualification that for value comparisons over time (also from place to place) it must be supposed that variations emanating from the monetary measure are precluded or that a correction is made for them:

En disant, par exemple, que telle circonstance a fait monter le prix d'une chose de 2 francs à 3 francs, je suppose que la marchandise appelée franc n'a éprouvé aucune variation; et si elle en a éprouvé, il est de droit qu'il faut faire à mon résultat une correction équivalente.

(Say 1819b, 2: 72)

The matter was important to Say since he emphasizes it in an effort to understand the source of his apparent differences with Ricardo. The elaboration comes in reaction to Ricardo's insistence in the chapter 'Value and Riches' on the relevance of the Smithian notion of riches in terms of the enjoyment derived from real goods independently of their values (above, p. 147). Say recognized the appeal made to Smith both by himself and by Ricardo, a fact that suggested to him that their difference must turn on some simple misunderstanding, one that he would attempt to clear up:

Toute cette doctrine est puisée dans mon Traité d'Economie politique (โ1817] liv. II, chap. IV), mais l'auteur en tire une conclusion opposée, c'est-à-dire que la richesse n'est pas la même chose que la valeur, tandis que j'établis que la richesse n'est que la valeur des choses. Ce qu'il y a de singulier, c'est qu'Adam Smith dit dans une circonstance comme M. Ricardo, et dans beaucoup d'autres circonstances, comme moi. On sent 
bien que des auteurs d'un si grand sens, et accoutumés à ne juger que d'après l'observation, ne peuvent être divisés sur ce point essentiel que par un malentendu; or, c'est ce malentendu qu'il faut éclaircir.

Say sets out by representing as a simple fact of life that riches - in the sense of a stock of goods - are expressed as a value magnitude. 'Que la richesse n'est autre chose que la valeur courante des choses qu'on possède, c'est un point de fait' (77). And since 'la richesse . . . n'est autre chose que de la valeur', it necessarily reflected two 'properties' of value. First its variability, from place to place and over time, a property that did not justify the conclusion - he implies it is Ricardo's - that wealth could not be quantified in value terms: 'En conclure que ce n'est pas de la richesse, ce serait vouloir conclure que la chaleur n'est pas de la chaleur, parce qu'il fait frais le matin et chaud à midi.' The second property of value is its 'relativity', Say reverting to the monetary medium, which did not preclude its use as measure of riches at any one timeagain an implied attribution to Ricardo (77-8). And it is indeed the case that Ricardo had in his letter of 18 August 1815 objected to a money measure of a capital inventory on just these grounds. ${ }^{2}$ But all this is by way of introduction, since in what follows Say explicitly alters the terms of reference from measurement of an actual stock to measurement of a potential flow.

The apparent paradox to be resolved - 'la grande difficulté - was that riches in terms of total utility ('la jouissance'), Ricardo's index, rises with output-expanding technical change, but falls in terms of total value, Say's index:

Comment se fait-il que lorsqu'un objet devient plus abundant, lorsque les bas, par exemple, tombent a moitié prix, je sois tout à la fois moins riche en valeur, et plus riche en jouissances? La somme de mes bas portés à l'inventaire sera moindre, et cependant mes jouissances seront accrues, puisque j'aurai un plus grand nombre de paires.

Ricardo had noticed elsewhere the dual usage of 'riches'; and Say was evidently troubled since he inserts a terminological adjustment disengaging 'richesse' from 'jouissance': 'Quand on considère dans les choses une qualité absolue, comme la jouissance qui résulte de leur usage, on n'en considère plus la valeur échangeable. On considère une jouissance, et non plus une richesse' (80). But this affects nothing of substance and is certainly not the solution to the apparent paradox upon which Say relies. The solution Say sets out by spelling out the transition from stock to flow - is that advances in technology raise real income, which he now calls 'richesse-revenu', as the purchasing power of nominal incomes rises; Say therefore identifies doubled riches with doubled 'jouissance', which is Ricardo's conception of things, but is nonetheless able to represent the assumed increase in output as 
entailing an increase in total value in the specific sense of the total value of productive services, upon a fall in the per unit exchange values of the product or products affected:

Que si vous considérez les bas non plus comme une marchandise déjà produite, mais comme une marchandise pouvant se produire, et qui en baissant à la moitié de son ancien prix, vous permet d'en consommer une double quantité ... sans pour cela faire un plus grand sacrifice, alors vous considérez la valeur des bas dans son rapport avec la valeur de votre revenu, et vous vous trouvez, relativement à ce produit en particulier, le double plus riche que vous n'étiez, puisqu'au moyen du même sacrifice, vous obtenez en ce genre une double jouissance.

In this manner, Say (as in the 1815 correspondence) saves his notion of riches as an exchange concept:

C'est en ce sens que, bien que la valeur soit la seule mesure de la richesse, une baisse de prix est une augmentation de richesse; puisque alors votre revenu a doublé par rapport aux bas; et si les perfectionnemens dans les procédés de la production avaient été pareils pour tous les autres produits, votre richesse-revenu serait véritablement double.

At this point Say repeats the claim made in the Traité that the 'solution' to the great problem constituted a wholly novel perspective that removed all difficulties (above, p. 144): 'Cette doctrine est fort importante; elle est rigoureusement conforme à la nature des choses, et par conséquent inébranlable, et elle explique des difficultés où l'on s'est perdu jusqu’à présent' (81). But this claim is impossible to accept since Ricardo in his chapter 'Value and Riches' had in fact argued along similar lines when he distinguished between expansion of total output due to growth of the productive labour force and expansion reflecting new technology: 'In the first case, a country would not only become rich, but the value of its riches would increase.... In the second case ... with the same labour more would be produced; wealth would increase but not value' (Ricardo 1951-73, 1: 278-9). And that Say himself recognized the identity of position is apparent, as we shall now see.

Say reacted with his standard objection that Ricardo, like Smith, limited resources to labour whereas by 'fonds productifs' he himself understood 'les terres productives, les capitaux productifs, l'industrie productive' (Say $1819 \mathrm{~b}, 2 \mathrm{z}$ ). But beyond this he had no objections, and he proceeded to paraphrase perfectly and fairly Ricardo's two cases in his own 'services' terminology - forgetting about land in this exposition: 
Dans sa première hypothèse, les capitaux accrus par l'épargne entretiendraient un plus grand nombre de travailleurs. Il y aurait plus de choses produites, mais ces choses étant le résultat de plus de services productifs, seraient dans le même rapport de valeur avec les services productifs. Le pays aurait plus de producteurs (capitalistes ou industrieux), mais aussi il aurait plus de consommateurs. Chacun, avec le même revenu, n'obtiendrait que la même quantité de produits. M. Ricardo regarde cette augmentation de richesses comme la moins désirable.

L'autre augmentation, en effet, est plus propre à procurer à chacun la libre disposition de plus de produits, de plus de jouissances. Elle consiste en un plus grand parti tiré des mêmes fonds productifs; d'où résulte, sans la moindre diminution dans le revenu, une baisse dans la valeur des produits, qui permet à chacun d'être mieux pourvu.

Now for this rendition of Ricardian doctrine Say here actually refers readers to his own solution to the 'grande difficulté': 'Voyez ma dernière note page 78' (above, p. 150). It seems then that Say recognized the identity of position.

The solution is then applied in response to Ricardo's charge in the Principles that Say had written in his Traité of the value added by free natural agents, whereas it was to riches in the sense of value in use that the additions were made (Ricardo 1951-73, 1: 285-6; see above, pp. 77-8). Smith, Ricardo had then remarked,

who defined riches to consist in the abundance of necessaries, conveniences and enjoyments of human life, would have allowed that machines and natural agents might very greatly add to the riches of a country, he would not have allowed that they add any thing to value in exchange [1821: to the value of those riches].

(286n.)

It is in response to this observation that Say reiterates exactly as in 1815 what he perceived to be his own contribution. Values do indeed fall with the adoption of labour-saving techniques but 'riches' rise in the specific sense of increased purchasing power of constant nominal income:

De mes dernières notes on peut inférer ma résponse à celle-ci. L'action gratuite des agens naturels, quand elle remplace l'action onéreuse des hommes et des capitaux, fait baisser la valeur des produits. Comme toute valeur est relative, la valeur des produits ne peut pas baisser sans que la valeur des revenus (ou des fonds productifs qui donnent ces revenus) n'augmente. Les consommateurs sont d'autant plus riches que les produits sont à meilleur marché.

(Say 1819b, 2: 91-2) ${ }^{5}$ 
In his last Note to the 'Value and Riches' chapter Say offers an alternative rendition of his solution, one entailing a formal distinction between 'natural' and 'social' riches. The former includes all goods ('des biens') - both free and scarce - that engender satisfaction:

Si l'on prend le mot richesses dans sa signification la plus étendue, les richesses de l'homme sont tous les biens qui, étant à sa disposition, peuvent, de quelque manière que ce soit, satisfaire ses besoins, ou seulement ses goûts. Dans ce sens, l'air que nous respirons, la lumière du soleil, et même l'attachement de notre famille et de nos amis, sont des richesses. Ce sont des richesses qu'on peut appeler naturelles.

(1819b, 2: 98)

A narrower category labelled 'richesse sociale' includes only scarce goods having value and reflecting some cost or sacrifice (99). And social riches alone was the concern of political economy, being quantifiable or 'susceptible de s'accroître, de se distributer et de se détruire' (99-100). The conceptual problem - 'la grande difficulté' - is expressed as always: how it comes about that with technical progress, output rises with a corresponding increase in total utility, identified by Say with 'richesse naturelle', whereas 'richesse sociale' - a value concept - apparently falls:

Maintenant la grande difficulté est de faire concorder les lois de la Richesse sociale, ou de l'Économie politique, avec celles de la Richesse naturelle. Lorsqu'un produit se multiplie par le meilleur emploi que nous faisons de nos terres, de nos capitaux, et de notre industrie, il y a plus d'utilité (soit de richesse naturelle) produite, et en même temps la production de la richesse sociale semble être moindre, puisque la valeur échangeable du produit diminue.

The problem as now formulated is that 'richesse sociale', a value concept, 'ne suit donc pas la même marche que la richesse naturelle', a utility concept; and in this complexity Say claims to find the source of the 'contradictions apparentes' that troubled Ricardo in Say's accounts.

The solution ${ }^{7}$ runs along the by-now standard lines. The problem was an apparent one only. Exchange values do increase in proportion to the tenfold expansion of output and total utility assumed, but in the specific sense of increased purchasing power of nominal incomes. This is apparent from what follows regarding the beneficiaries of the new technology: 'Il reste à connaître quels sont ceux qui profitent de cette augmentation, ceux qui sont plus riches, non-seulement en richesses naturelles, mais en richesses sociales, en valeurs échangeables, de tout cet accroissement d'utilité produite' (101-2). 
Now Say does not take for granted that output increase is always accompanied by reduced price; his example is corn and we know that he followed Smith in allowing for constancy of the corn price. In the case of constant price, producers alone benefit from the new technology as their revenues rise in proportion (102). But in the usual case of reduced price with output expansion, it is consumers who benefit from the increased purchasing power of their nominal incomes, to an extent depending on budget allocation:

Si . . . la valeur échangeable de chaque boisseau de blé a baissé en raison de la plus grande quantité qui en a été produite, le profit obtenu est bien toujours dans la proportion de cinq cents à cinquante; mais ce profit est fait par la classe des consommateurs, lesquels sont aussi riches de ce qu'ils payent de moins que les producteurs l'auraient été de ce qu'ils auraient vendu de plus. Leur revenu n'a pas décuplé, parce qu'ils ne l'emploient pas tout entier en froment; mais la portion de revenu qu'ils avaient coutume d'employer en froment a décuplé, et toutes ces portions de revenu ainsi décuplées se monteraient, si elles étaient réunies, à une somme égale à la valeur décuplée du produit, en supposant qu'il n'eût pas baissé de prix.

Say asserts in summary that ' $[\mathrm{d}]$ ans les deux cas, la société a donc joui d'une augmentation de valeurs comme d'une augmentation d'utilité' - which is what he had set out to demonstrate.

*** $*$

We turn from the 1819 Notes to the 1819 edition of the Traité (Book II, Chapter 2 'Des sources de nos revenus') where the Say solution to the tricky 'difficulty' is expounded. Once again, an increase in 'riches' entails a greater flow of outputs - expressed also in Ricardian terms as 'une plus grande masse d'utilité produite' - but may be expressed as an increase in 'la valeur du revenu' in the specific sense of purchasing power enjoyed by service suppliers:

Cette analyse nous était nécessaire pour parvenir à connaître la véritable valeur du revenu. Qu'est-ce en effet que la valeur suivant la définition donnée dans le dernier chapitre? C'est la quantité de toute autre chose, qu'on peut obtenir en échange de la chose dont on veut se défaire. En matière de revenu, quelle est la chose dont on se défait pour obtenir son revenu? Des services productifs qui naissent incessamment des fonds qu'on possède. Qu'obtient-on dans cet échange que nous appelons du nom de production? Des produits. La valeur du revenu est donc d'autant plus considérable qu'on obtient, non pas une plus grande valeur en produits, mais une plus grande quantité de produits, une plus grande masse d'utilité produite.

(Say 1819a, 2: 26) 
... le revenu d'une nation est d'autant plus considérable que la valeur dont il se compose (c'est-à-dire la valeur de tous ses services productifs) est plus grande, et la valeur des objets qu'il est destiné à acheter plus petite. La valeur des services productifs est même nécessairement considérable, quand celle des produits l'est peu; car il ne faut pas perdre de vue que la valeur se composant de la quantité de choses qu'on peut obtenir dans un échange, les revenus (les services des fonds productifs de la nation) valent d'autant plus, que les produits qu'ils obtiennent sont abondans et à bas prix.

The concern is all this is thus real national income: 'C'est comme on voit, la quantité des produits et non leur valeur qui fait le revenu des nations vu en masse', since regarding individual incomes there was the complication that because of changes in relative prices 'le revenu d'un particulier peut être accru aux dépens de celui d'un autre particulier' (26-7; emphasis added).

Say summarizes his position in the chapter 'Des variations réelles et des variations relatives dans les prix' in a statement (addressed at the Physiocrats and Sismondi) regarding the effect of technical change in lowering cost prices but raising real incomes - Say's test case. The Epitome in the 1819 edition under RICHESSE spells out particularly clearly the contrast between valuation of an existing stock of commodities and of an income flow. The value of the former falls with a fall in commodity prices:

On est riche soit en produits déjà créés, soit en fonds et en revenus. Quand on est riche en produits, cette richesse peut être affectée par la hausse ou la baisse de ces produits: on est plus riche quand ils haussent; on l'est moins quand ils baissent.

(Say 1819a, 2: 501)

The value of an income flow, on the other hand, increases with reductions in commodity prices:

Lorsqu'on est riche en fonds et en revenus, c'est-à-dire en richesses perpétuellement renaissantes, on est d'autant plus riche que les produits sont moins chers. Car toute valeur est relative. Celle des fonds et des revenus est d'autant plus grande, que celle qu'on acquiert avec des fonds et des revenus est plus petite. (La petite valeur des produits et leur grande quantité sont un seul et même effet ....).

The entry under PRODUCTION is equally helpful:

la valeur des services productifs qui sont la chose avec laquelle on achète les produits (même ceux que d'autres personnes ont créés) ne baisse point, mais augmente par la baisse des produits; la valeur de ceux-ci n'est pas 
la valeur acquérante dans cet échange appelé PRODUCTION, mais bien la valeur acquise, et la valeur acquérante est d'autant plus considérable que la valeur acquise est moindre.

\section{The late Say-Ricardo exchange 1821-2}

The letter of 19 July 1821 should be mentioned here as confirming Say's primary concern not with the value of an existing stock but with the real counterpart of the flow of income which he here refers to pointedly as 'richesses nouvelles'. The relevant statement occurs in a paraphrase of the proposition that ' $[u]$ ne grande utilité qui peut se donner a peu de frais, rapproche la chose à laquelle elle est conferée, d'une richesse naturelle, d'une chose qui a son utilité par elle-même et sans frais' - a free good; 'mais en Économie politique, nous ne pouvons nous occuper que de la portion d'utilité qui a été donnée avec des frais' (in Ricardo 1951-73, 9: 33). The paraphrase reworks this cost theme in terms of productive services as is Say's standard practice:

En d'autres termes, les seules richesses nouvelles sont des services productifs, premiers fruits de notre industrie, de nos capitaux, et de nos terres. On les échange entr'eux, ou bien on échange leurs produits; et la quantité que l'on donne des uns pour avoir les autres, est l'indication de la valeur qu'on y attache, valeur qui seule fait le sujet de notre étude.

(Emphasis added)

But what of Ricardo? How did he view the matter? We recall his remark in his third edition that there were 'many parts of M. Say's work to which I can confidently refer in support of the doctrine which I maintain, respecting the essential difference between value and riches' (1951-73, 1: 281). The problem was that he found Say to be inconsistent. In his letter of 5 March 1822 he illustrates from the second edition of the Catéchisme where riches appear on the same page both as value and as quantity:

we are told [Say 1822: 2] that riches are in proportion to value, and value in proportion to the quantity of things, therefore riches are in proportion to the quantity of things; and yet you say that riches are in proportion to value, and not in proportion to the quantity of things.

(Ricardo 1951-73, 9: 170)

Also troublesome - and this takes us back to our central issue - was Say's reference in his Lettres à M. Maltbus (Say 1821 [1820]: 28-9) to the proposition in the 1819 Traité whereby output-enhancing technical change lowers cost prices yet increases riches, an outcome in line with Ricardo's perspective but clashing, so it seemed to Ricardo, with Say's measurement of riches in terms of value since values have fallen. 
Say's defence, dated 1 May 1822, against the charge of inconsistency proves helpful in removing the fog still surrounding the debate. In his reply Say allows that riches could be perceived as the useful output actually possessed by an individual who wishes to retain those goods, but insists that political economy was interested solely in those goods as far as they are means to purchase other goods:

La contradiction apparente que vous trouvez ici, Monsieur, vient de ce que vous ne faites point, comme moi, une différence entre la quantité de choses utiles dont un homme peut jouir, et la quantité de choses utiles qui peuvent servir à faire une acquisition. Suivant moi, cette dernière quantité de choses utiles compose seule la richesse dont l'Economie politique puisse s'occuper, parce que l'accroissement ou le décroissement de cette seule quantité, sont soumis à des lois qu'elle puisse assigner.

(Say, in Ricardo 1951-73, 9: 189)

But Say goes further. 'Useful goods' extended to free goods, whereas he included within riches only scarce goods or goods that have exchange value: 'Ce n'est point le cas des choses utiles ou agréables qui ne peuvent servir à faire une acquisition, qui n'ont point de valeur échangeable.' Free goods were excluded from an individual's 'fortune' and indeed from the subject matter of political economy: 'leur accroissement et leur décroissement, ne dépendent pas des lois de l'Economie politique, mais de lois physiques qui sont étudiées par ceux qui s'occupent de géologie et d'histoire naturelle'. Say thus bases his defence of the measure of riches in value terms - and deflects the charge of inconsistency - upon the notion that he alone included within riches those products that do have exchange value, whereas Ricardo, by working in terms of (unquantifiable) value in use, included even free goods. This latter attribution is unjustified; riches for Ricardo, as well as for Say, comprised only scarce goods, that is goods with exchange values, but could not be measured in those terms.

An implication of Say's perspective is the relativity dimension characterizing 'richesse sociale':

Par une suite nécessaire, je ne saurais séparer l'idée de la richesse sociale, de l'idée d'un possesseur, et je vous avoue que je désapprouve toutes les définitions des richesses où l'on ne fait pas entrer l'idée d'un homme ou d'une autre communauté qui les possèdent, et d'un autre homme ou d'une autre communauté qui ne les possèdent pas et qui ont le désir de les acquérir. ${ }^{8}$

Now this insistence on the relativity or exchange dimension in discussing valuation of a stock served, as it did throughout Say's formal texts, as an introduction to his solution to the knotty problem raised by Ricardo, that output-increasing technical progress apparently lowers riches in value terms. 
Ricardo, Say contended, had failed to grasp that riches $d_{0}$ in fact rise in value when cost prices fall, in the specific sense of an increase in the real income of service suppliers, thus satisfying the 'relativity' or 'exchange' condition - in this case, the command by income recipients over real goods:

Vous me dites: 'Let us suppose that the same cause, namely an economical process which lowers the value of gold one half, lowers at the same time, in the same degree, hats, shoes, etc. In this state of things, a pound of gold will command just as many hats, shoes, etc. as before. . . I ask is the man equally rich as before who has a pound of gold? You first answer $N_{0}$ because he has not a commodity of equal value, etc.'

Je vous demande bien pardon: je ne réponds pas Non; je réponds Oui, car, dans cette supposition, une livre d'or peut acheter la même quantité de produits et que la valeur échangeable de la livre d'or est en proportion de la quantité de choses qu'elle peut acheter. Mais en même tems je dis que les services productifs (qui forment nos revenus) ont doublé de valeur, puisque une pareille quantité de services productifs, peut obtenir une double quantité d'or, de chapeaux, de souliers, etc.

(190-1; emphasis added)

Say goes on to point out, as in the Notes (above, note 4), that the increase in the 'value' of services reflects back on their sources - land, labour and capital - in which sense the nation could be said to be doubly wealthy:

Et comme le doublement de la valeur des services productifs (c'est à dire des services de l'industrie, des capitaux et des terres) double la valeur des fonds d'où ils proviennent (qui sont les facultés humaines, les capitaux, et les terres) j'en conclus que, dans votre supposition la nation est le double plus riche. Ses produits valent autant et leur quantité est doublé.

But none of this is in any way controversial; certainly no one ever doubted that doubled output resulting from technical change must be reflected in an increased (real) return to one or more of the productive services.

\section{Post-1823 statements}

Probably with publication in mind, Say in 1825 made alterations to the two letters dated 19 July 1821 and 1 May 1822 discussed above (Sraffa, in Ricardo 1951-73, 9: 31n., 188n.). A comparison of the alternative versions of the first of these letters suggests that Say was approaching ever closer to Ricardo with respect to the sense of riches as real output independently of its value. Agreement on 'essentials' is expressed already in the letter actually sent: 'Au milieu de ces dissentimens, c'est néanmoins un bien bon signe que nous soyons d'accord sur l'essentiel; je veux dire sur la possibilité qu'ont les 
hommes de multiplier leurs richesses' (Say, in Ricardo 1951-73, 9: 31). But in the revised version Say all but identifies 'richesses' with 'bien-être' which amounts, of course, to Ricardo's value in use independently of exchange value:

$\mathrm{Au}$ milieu de ces dissentiments, c'est toutefois un très-bon signe que nous nous accordions sur l'essentiel, je veux dire, sur la possibilité qu'ont les hommes de multiplier leurs richesses et leur bien-être, ainsi que sur les moyens par lesquels on peut parvenir à ce but. Nous arrivons tous aux mêmes conclusions, quoique, dans un petit nombre de cas, par des routes diverses.

(Say 1843: 605; emphasis added)

And this is confirmed in an elaboration of his reaction to Ricardo's response to his analysis of the uniform price of two loaves assuming differential land productivity, to the effect that Say's perception of things entailing the 'doctrine of services' was, albeit valid, 'not useful and can lead to no inference whatever that can guide our future practice' (Ricardo 1951-73, 8: 380; above, p. 76). In the letter actually sent Say wrote rather cryptically:

Il me semble au contraire que nous en pouvons tirer cette induction que les grands progrès de la production consistent dans la substitution des services gratuits de la nature à la place des services dispendieux de l'industrie, des capitaux et des terres.

(Say, in Ricardo 1951-73, 9: 35)

But the revised version of the letter goes further explicitly identifying riches with utilities in one of the very few pleasantries to enliven the debate:

si, par une supposition impossible à réaliser complètement, nous parvenions à obtenir par des services gratuits toutes les utilités imaginables, nous serions tous plus riches que David Ricardo, car il y a des choses désirables qui surpassent la portée des plus grandes fortunes.

(Say 1843: 607)

That increased output increases total utility independently of value is of course pure Ricardo.

But if change there was, it was not carried through consistently. For a paragraph absent from the version of the letter actually sent reiterates the difference with Ricardo over the matter of riches in utility or in value terms, and seeks to account for Ricardo's hesitations:

Je vois que, dans votre dernière édition, vous vous êtes beaucoup étendu sur ma manière de voir relativement à la valeur des choses (que je regarde, et que vous ne regardez pas, comme la mesure la plus sûre des richesses). Le sujet est important; et je crois que ce qui nous empêche 
d'être d'accord c'est que vous donnez trop peu d'attention aux deux sortes de richesses que je n'ai pas pu distinguer autrement que par les noms de richesses naturelles et de richesses sociales.

Here Say reverts to his perspective on riches measured in value terms and to his invalid contention that Ricardo included free goods within riches.

$$
* * *
$$

Late statements in the Traite of 1826 and in the Cours complet of 1828-9 assist us in our endeavour to pin Say down. Consider first a footnote added in the Traité of 1826 attached to a comment in the text regarding technical change whereby free forces of nature replace costly labour and capital, the same issue as in the correspondence discussed above. The text itself appears also in earlier editions:

la nature est presque toujours en communauté de travail avec l'homme et ses instrumens [1814, 1817: avec l'homme]; et dans cette communauté nous gagnons d'autant plus, que nous réussissons mieux à épargner notre travail et celui de nos capitaux, [added 1817: qui est nécessairement coûteux] et que nous parvenons à faire exécuter, au moyen des services gratuits de la nature [1814, 1817, 1819: à faire exécuter à la nature], une plus grande part des produits.

(Say 1814, 1: 30; 1817, 1:30-1; 1819a, 1: 30-1; 1826a, 1: 36)

Now the new note of 1826 not only accepts that the added 'production' Say intends 'riches' as the context makes clear - resulting from advanced technology implies an addition to total utility as Smith and Ricardo had it, but insists also on an addition to total exchangeable value but in the special sense of the increased purchasing power of nominal incomes:

On verra plus tard (liv. II, chap. 4) que cette production, qui est le fait de la nature, ajoute aux revenus des hommes, non-seulement une valeur d'utilité, la seule que lui attribuent Smith et Ricardo, mais une valeur échangeable. En effet, quand un manufacturier, à l'aide d'un procédé qui lui est particulier, parvient à faire pour 15 francs un produit qui, avant l'emploi de ce procédé, coûtait 20 francs de frais de production, il gagne 5 francs aussi long-temps que son procédé demeure secret et qu'il profite seul du travail gratuit de la nature; et quand le procédé devient public et que la concurrence oblige le producteur à baisser le prix de son produit de 20 francs à 15 francs, ce sont alors les consommateurs du produit, qui font ce gain; car lorsqu'une personne dépense 15 francs là où elle en dépensait 20 , elle jouit d'une valeur de 5 francs qu'elle peut consacrer à tout autre emploi.

(Say 1826a, 1: 36-7n.) 
Here then Say reaffirms particularly clearly the coincidence of an increase in 'riches' as output with reduced cost prices - the solution to the 'grande difficulté' of earlier years. But once again he misleads in implying that the effect of cost-reducing technical change in raising real incomes was his contribution alone.

The 1826 text of the chapter 'De ce qui fait l'importance de nos revenus' reiterates the 1819 formulation in the chapter 'Des sources de nos revenus' (above, p. 154), expressing with even greater clarity the notion of riches as real-income flow to service suppliers which is increased by new technology via its effect in reducing cost prices:

Cette analyse nous était nécessaire pour parvenir a connaître la véritable valeur du revenu. Qu'est-ce en effet que la valeur suivant les définitions déjà données? C'est la quantité de toute autre chose, qu'on peut obtenir en échange de la chose dont on veut se défaire. Dans cet échange que nous appelons production, quelle est la chose que nous donnons? Nos services productifs. En quoi consiste leur importance? Qu'est-ce qui leur donne de la valeur? C'est la quantité des produits, que nous recevons en échange c'est-à-dire la quantité des produits qu'ils nous procurent. D’après les principes qui déterminent la valeur des choses, nos services ont donc d'autant plus de valeur qu'ils nous procurent non des produits plus chers, mais des produits en plus grande quantité. Or, des produits reçus en plus grande quantité, équivalent exactement à des produits qui sont à meilleur marché par rapport aux services dont ils sont les résultats.

(Say 1826a, 2: 220-1)

Application of the principle to aggregate income is apparent:

les revenus des nations sont d'autant plus considérables, que les produits y sont à meilleur marché; proposition qui, au premier abord, semble, mais qui n'est pas contradictoire avec celle qui fait consister la richesse dans la valeur des choses qu'on possède.

Say unfortunately misleads his readers by continuing to criticize those who define riches in utility terms, when this is precisely what he is doing once he specifies his concern to be valuation in the sense of the purchasing power - or exchange value - of nominal income rather than the valuation of an existing stock of goods. Thus, for example, he restates in 1826 his complaint of 1819 (above, note 7) against his brother Louis:

Il pose que les choses ne sont des richesses qu'en raison de l'utilité qu'elles ont, et non en raison de celle que le public leur reconnaît en les payant plus ou moins cher. Il est très-vrai que les hommes devraient 
toujours en juger ainsi; mais en économie politique il ne s'agit pas d'apprendre ce qui devrait être, mais ce qui est; de constater un fait, d'en assigner les causes, et d'en montrer les conséquences.

$$
* * *
$$

We turn now to the Cours complet. After rehearsing his case for a value index of 'riches' (above, p. 97), Say takes up the 'grande difficulté' of the 1819 Notes and the Traité: 'La richesse étant composée de la valeur des choses possédées' -one notes the stock dimension - 'comment se peut-il qu'une nation soit d'autant plus riche, que les choses y sont à plus bas prix?' (Say 1843: 174). As in the earlier formulations, the solution involves the purchasing power of revenues or real income, Say silently switching to Ricardo's (or Louis Say's) definition in terms of output and corresponding 'jouissance'; noteworthy is his adoption of the term 'richesses réelles' rather than simply 'richesse':

Nos richesses réelles sont en proportion de la quantité des choses que nous pouvons acquérir, et cette quantité est en proportion de leur abondance, ou, ce qui est la même chose, de leur bas prix. ... Toute baisse dans les prix est un pas qui rapproche les produits de ces biens naturels dont nous jouissons avec la plus abondante profusion, sans que nous soyons jamais obligés de les payer.... [L]es individus ... deviennent plus riches, chaque fois qu'ils peuvent acquérir à moins de frais, tantôt l'une, tantôt l'autre des choses qu'ils veulent consommer.

This 'solution' is then nicely rephrased in Sayian terms of services in a flow context:

il faut considérer qu'une nation ne s'entretient, ne se conserve, qu'à l'aide des produits qui sont incessamment créés et consommés. . . Elle ne subsiste que des produits dont elle fait l'acquisition à leur prix d'origine. Or avec quoi fait-elle cette acquisition? Avec ses services productifs qui émanent, vous le savez, de ses fonds productifs, c'est-àdire de son industrie, de ses capitaux et de ses terres. Ce sont là proprement nos fortunes, puisque c'est l'unique source de tous nos revenus. Or nos fortunes sont d'autant plus considérables qu'elles peuvent acquérir plus de choses, et nos fonds productifs, qui composent nos fortunes, peuvent acquérir d'autant plus de choses que les produits sont à meilleur marché.

Say was wholly obsessed by the issue, for we find it once again spelled out later in the text, with the initial presumption in favour of riches as value followed by the now standard transition to income flow: 
Maintenant, ce que j'ai dit sur ce qui fait une richesse plus ou moins grande, je le dis des revenus qui sont plus ou moins grands, selon la quantité plus ou moins grande des choses qu'ils peuvent nous procurer. C'est pour la même raison encore que, si nous remontons plus haut, à la source de tous les revenus, aux services productifs que rendent nos terres, nos capitaux, ou notre travail, nous trouvons qu'ils valent d'autant plus que les produits, même ceux auxquels ces services ont concouru, sont à meilleur marché. [Note: Voyez le chapitre 5 de la IIIe partie où sont consignés les principes fondements de cette doctrine.] Les services sont le prix auquel on achète les produits. Plus on obtient de produits, directement (en les produisant) ou indirectement (en les achetant), avec les services d'un jour, d'un mois, d'une année, et plus ces services, ou le prix qu'on en obtient, ont de valeur.?

The foregoing renditions not only correspond to Ricardo's representation of riches in product terms, but confirm that the doctrine of services is merely an alternative, if preferable, version of orthodox cost doctrine. Indeed, Say affirms that the solution might be equally represented in such, albeit less 'scientific', terms: 'On peut dire que les frais représentent toujours un sacrifice, et l'utilité une jouissance; or c'est un avantage pour l'homme que de multiplier ses jouissances et de diminuer les sacrifices au prix desquels il les obtient' (174).

Yet despite the identity of position - and notwithstanding the apparent recognition of agreement in the 1819 Notes (above, p. 152) - Say still insisted in the Cours complet that his analysis ran counter to Ricardo's. This emerges in the course of yet another formulation of the 'solution' to his 'thorny' problem, where again he sets out by defining riches in terms of value only to lay aside that definition in favour of riches as output:

La richesse est en proportion de la valeur des choses qu'on possède, et la valeur en proportion de la quantité de choses consommables qu'elles peuvent acquérir. Or notre propriété constante, ce qui nous fournit incessamment le moyen d'acheter les choses que nous voulons consommer, ce sont nos fonds; nous sommes d'autant moins riches en fonds, que, quel que soit leur prix nominal et le prix des produits qui en sortent, nous ne pouvons acheter par leur moyen qu'une moins grande quantité de choses.

This solution, allegedly unrecognized by Ricardo, confuted - so runs the charge - Ricardo's taxation analysis:

Cette doctrine, complètement confirmée par l'expérience de tous les temps et de tous les pays, est méconnue de David Ricardo, et faute de l'avoir adoptée, je crains qu'il ne se trompe dans la plupart des explications qu'il 
donne des phénomènes de l'impôt. Il dit que, 'si un contribuable paye 100 francs au gouvernement, le gouvernement possède 100 francs de plus à dépenser, en place du contribuable' [Ricardo 1953-71, 1: 238-9]. Il en résulte bien en effet que la somme totale des revenus de la société n'a pas été diminuée; mais les frais de production ayant été augmentés du montant de l'impôt, les mêmes revenus ne peuvent pas acheter la même quantité de produits.

In fact, the 'correct' outcome Say insists on here is not based on a peculiarly non-Ricardian definition of 'riches'. It reflects rather an objection to inclusion of government services within national income, as implied by the close of the extract. There is too a concern in the taxation context with immobilities of various sorts in any transition process engendering capital losses including human capital - a matter taken up below (p. 180).

That Say should provide yet a further rendition of the main theme in Part IX of the Cours complet and restate the key to the problem said to be hitherto unsolvable - that while riches comprise values, yet a nation is 'richer' the lower are values - is an index of the centrality of this matter to him and pride in his allegedly innovative 'solution'. The elaboration, where we again find riches expressed in terms of 'une plus grande quantité' and the cost doctrine reaffirmed, is wholly 'classical', though a reader is never allowed to see this:

Quand, par un progrès de l'art, le produit revient moins cher au producteur, il peut, sans y perdre, le faire payer moins cher au consommateur, c'est-à-dire à la société, qui ne subsiste que par ses consommations. Dans ce grand échange que nous avons appelé production, la société donne alors moins pour obtenir plus. Elle fait un gain, non aux dépens d'une partie des associés, mais aux dépens de la nature.... [L]es consommateurs d'un produit jouissent pour le même prix d'une plus grande quantité ou d'une meilleure qualité, et les producteurs ne gagnent pas moins; car ils peuvent, sans y perdre, donner à plus bas prix ce qui leur a coûté moins de frais de production. Un pareil avantage peut s'obtenir successivement par rapport à tous les produits: car une baisse de ce genre n'est pas relative; elle est réelle. Dans ce cas, le prix d'une marchandise ne se compare pas avec le prix d'une autre, mais avec les frais de sa production, avec le prix qu'elle coûtait auparavant.

A note critical of the Physiocrats further demonstrates Say's intention to elucidate the nature of production with an eye on costs, for these 'sectarians' had neglected that dimension:

Les sectateurs de Quesnay regardaient tout renchérissement comme un bien, parce qu'une plus grande valeur est une plus grande richesse. Ils 
n'envisageaient la question que d'un seul côté; ils ne s'occupaient que de la valeur vénale des produits et ne pouvaient pas savoir encore à quel prix on les obtient, parce que le phénomène de la production n'était pas alors complétement analysé.

All very true - and all very canonical.

\section{Malthus on Say and 'riches'}

The grand debate between Ricardo and Say regarding 'riches' turns out to have been unnecessary since Say, at least in the income-flow context, effectively abandoned his insistence on riches as a value entity in favour of Ricardian product or total utility terms. It is not a matter of a change in position on Say's part, since he had proposed his 'solution' in the Traité before the exchange with Ricardo began. But the accord was heavily disguised by the fact that Say always set out his argument by insisting strongly on the value index in discussing stock valuation, only to abandon it when changing the terms of reference to real income. We illustrate this pattern by considering the Malthus-Say nexus.

We recall to begin with Say's objections in his Lettres à Malthus to Malthus's representation of the 'cornerstone' of the Wealth of Nations as the productive-unproductive labour distinction (Say 1821 [1820]: 37). Rather, the lasting contribution of Smith's work lay in its doctrine 'that the exchangeable value of things is the foundation of all riches' (20). As we have seen elsewhere (above, p. 79), Say saw this as providing the scientific basis for political economy:

From the publication of that important truth, political economy became a positive science; for the market-price of every thing is a determinate quantity of which the elements may be analysed, the causes assigned, the relations studied, and the consequences foreseen. Permit me, Sir, to say that to separate this essential character from the definition of wealth, is to plunge the science again into the depths of obscurity - to drive it back.

Say reverts to this perspective in the context of his distinction between natural riches, which do not fall within the domain of economic science, and social riches, which do: 'Which then are the riches within the jurisdiction of that science? - Those which are susceptible of creation and destruction, of more and of less; and what, I again ask, is this more, this less, but value?' (77). And it is exchangeable value only that is intended, not the particular value an individual may set on an object as representing its utility to him:

In order to constitute riches, the value must be recognized, not by the possessor merely, but by other persons. But what more irrefragable proof 
that its value is recognized can be given than that other persons are ready to give for it a certain quantity of other things which are valuable.

He failed to see how Malthus could possibly exclude exchange value from his formal definition of 'wealth' or 'riches' (81). Smith was to be applauded for abandoning 'value in use' and concerning himself entirely with 'value in exchange' (78). Say did not actually deny Malthus's insistence that riches consist in 'the quantity of necessary and agreeable things we possess'; he objected rather to the use of words that

have a very vague and arbitrary meaning, unfit to enter into a perfect definition: I render them precise and clear by the idea of their exchangeable value. The condition of utility then is the being equal to another utility, which men are willing to give in exchange for that which you possess.

Now we shall see that Malthus was in fact closer to Say than Say ever imagined. But Say placed Malthus and Ricardo together: 'I will not deny ... that you have, in Mr. Ricardo, a powerful and respectable ally. He is against you in the subject of markets [the aggregate-demand issue], and fights on your side in the question of value' (78). The specific issue here is Ricardo's distinction between value and riches reflected in the fact that reduced scarcity as a result of technical change lowers per unit value but increases total riches. It is a position Malthus certainly appeared to follow in the Principles:

Stockings do not lose half their power of contributing to the comfort and convenience of the wearer, because by improved machinery they can be made at half the price, or their exchangeable value be reduced one half. It will be readily allowed that the man who has two pairs of stockings of the same quality instead of one pair, possesses, as far as stockings are concerned, a double portion of the conveniences of life.

(Malthus 1820: 338)

But this accord with Ricardo is qualified by Malthus in a major way. Ricardo was right with respect to a particular commodity, but

when we come to compare objects of different kinds, there is no other way of estimating the degree of wealth which the possession and enjoyment of them confer on the owner, than by the relative estimation in which they are respectively held, evinced by their relative exchangeable values.

This brings Malthus very close to Say, at least Say's formal declarations regarding riches as a value concept. 
Malthus's agreement with Say is expressed in a letter to Ricardo dated 13 September 1821, subject to the single qualification that exchangeable values be expressed in terms of objects 'least variable to variation' rather than any object as Say had it in his letter to Ricardo of 19 July to which Malthus had access:

At the same time I should say, that as there is certainly no measure of utility, taken in the common acceptation of the term, and as a part of the same article, how useful soever, may become quite useless if it be in excess above the demand, there is no other way of approximating towards an estimate of relative wealth, than by an estimate of relative value, formed by a comparison with the objects least liable to variations (but not, as Mr. Say says, merely with the 'la plus ou moins grande quantité d'un autre produit quelconque [in Ricardo 1951-73, 9: 32]'.

(Malthus, in Ricardo 1951-73, 9: 64)

Say in fact had actually been too hasty in referring to exchange value relative to a good selected at random, since elsewhere he had proposed either the monetary metals or a corn measure. Malthus himself doubtless had in mind the labour-command measure which Say had rejected as too variable an index. ${ }^{10}$

We have here a complex picture indeed, Malthus agreeing with Say on 'riches' as a value concept, but with Say identifying Malthus with Ricardo as adopting a utility dimension. Adding to the complexity is the fact that Say himself in fact belongs to the Ricardo camp with respect to riches, as was already discernable in all the editions of the Traité that had already appeared and in his Notes of 1819 (above p. 152). This accord with Ricardo emerges even in the Lettres itself, though Malthus evidently did not hear the message, at two locations.

At the close of the Lettres Say places his perspective on riches into a framework representing production as an exchange process. An increase in productive power - the test case in the Say-Ricardo debate - would raise the exchangeable value of the productive services in the sense that their command over goods (and presumably menial and other services) rises, such greater command 'perfectly synonymous' with 'greater cheapness' (Say 1821 [1820]: 82). Ricardo's objection, 'that by improved processes a million of people might produce twice or thrice as much riches, without producing more values', is answered 'when we consider, as we ought, production as an exchange in which the productive services of labour, land, and capital is given, in order to obtain the production'. Say here, as in his direct discussions with Ricardo, maintains that costs and prices fall per unit with technical change thereby raising the purchasing power over real goods of some or all of the income recipients. Without formally admitting it, Say accepts the Ricardo position that technical progress increases 'riches' in terms of total output and not total value, and disguises - perhaps from himself as well as his readers - the common ground by expressing the matter in terms of his doctrine of services. 
The same theme will also be found earlier in the Lettres, in reference to the elaboration in the Traité (see above, p. 154) of the proposition that 'although wealth is an exchangeable value, general wealth is increased by the low price of commodities and production of all sorts' such as is generated by technical progress. The essential point, as always, is that reduced prices reflecting output expansion raise the exchangeable value of productive services, and in this specific sense 'riches' can be said to increase with costcutting technical change:

Productions in such an exchange are valued against productive services; now as in every exchange, the value of one of the terms is greater in proportion to the greater quantity of the other which it obtains, it follows that productive services are increased in value in proportion as productions are increased in quantity, and diminished in price. This is the reason why the reduction of the price of productions, by increasing the value of the productive funds of a nation and of the income derived therefrom, augments the national wealth. I think this demonstration, which may be seen at length in my Traité d'Economie Politique, 4th edition, book ii, ch. 3 , has done some service to science by elucidating what previously had been felt, but not explained, that is to say, that although wealth is an exchangeable value, the general wealth is increased by the low price of commodities and productions of all sorts.

(Say 1821 [1820]: 28-9; emphasis added)

Now this proposition is actually said to confound both Malthus and Ricardo in major respects, once more confirming the high importance attached by Say to the debate over riches and illustrating how easy it is to imagine a great conflict between the protagonists where none exists:

This demonstration, by the bye, completely overthrows an assertion of Mr. Malthus, that cheapness is always (must be) at the expense of profits [Malthus 1820: 370], and consequently all the reasoning which he has built on this foundation. It is also fatal to all that part of Mr. Ricardo's doctrine, in which he flatters himself that he has proved, that the costs of production, and not the proportion of supply and demand, regulates the prices of goods. He identifies the costs of production with the production itself, whereas they are completely opposed to each other, and the former are diminished in proportion to the increase of the latter.

The charge against Malthus relates to a presumed increase in the real (commodity) wage reflecting 'the abundance and cheapness of commodities', which Malthus indeed says 'must be at the expense of profits' (Malthus 1820: 370). Say is right that in the event of technical improvement an increase in the real wage may coincide with an increase in the profit rate. But, of 
course, the canonical wage-profit theorem captures this characteristic. Say's remark relating to Ricardo on costs fails to recognize that Ricardo did not reject demand-supply theory by his according primacy to costs and supply. More to the point for us here, the charge that Ricardo identified costs with production is groundless; for Ricardo too, of course, unit costs will fall if output increases as a result of technical improvement and real income will increase, as with Say.

$$
\text { * * * }
$$

The story has a happy ending, all parties finally arriving at the same destination - without realizing it. Thus in his Definitions of 1827 Malthus objects to Say's assertion that utility is measured by exchange value 'when things are in their ordinary and natural state' - alluding to cost prices - since Say also maintained that 'riches' are proportional to value:

And as M. Say observes, that when things are in their ordinary and natural state their value is the measure of their utility, while he had before affirmed that riches were in proportion to value [Say 1819a, 1: 2-4], it is difficult to conceive what beneficial purpose he could have in view in introducing the term utility thus made synonymous with value or riches.

(Malthus 1986 [1827c], 8: 15)

This reads much like Ricardo's position on Say (above, pp. 70-1). And indeed here, as on earlier occasions, we find a commendation of Ricardo for clearly distinguishing between 'riches' and 'value', whereas Say 'introduces another term, utility, which as he applies it, can hardly be distinguished from either of the others'; by neglecting Smith's contrast between value in use and value in exchange, Say had 'gone directly against ... the authority of Adam Smith, whom he himself considers as the main founder of the science' (14-15). Again - arguing in Ricardian terms - by the value of a commodity is intended specifically the conditions of supply of that commodity: "practically, when we speak of the value of a commodity, we almost exclusively refer to the circumstances which affect its plenty or scarcity, to the conditions of the supply of the commodity itself, and not to those which affect others' (Malthus 1986 [1827b], 7: 318). Now to measure changes in value is to measure changes in supply conditions and not wealth, a contrast reinforced by formal adoption of Ricardo's distinction against Say between 'riches' and 'value':

when the same quantity of iron and broadcloth will command a greater quantity of the mass of all other commodities, the persons possessing this iron and broadcloth will be decidedly better off than before. But they will be better off, because they have the power of commanding a greater quantity of wealth, not because they have the power of commanding a greater quantity of value. I entirely agree with Mr. Ricardo [1951-73, 1: 280-1] that if two sacks of wheat be of the value that one 
was before, the clothier who exchanges his cloth for them obtains the same value that he did, and no more, although he may obtain double the quantity of riches.

(Malthus 1986 [1827b], 7: 317-18)

Similarly, discussing the term 'different values of the precious metals in different countries' (321), Malthus refers favourably to Ricardo's position (Ricardo 1951-73, 1: 377) that the 'value' of gold - in the specific sense of its purchasing power - will differ, depending on which particular set of commodities is adopted in the exercise. And there is certainly no commodity, or set of commodities, which can with any degree of accuracy represent [the] mass', that is all the products in the system (Malthus 1986 [1827b], 7: 322). That there is no quantitative measure of wealth or riches as such is, indeed, Ricardo's position.

But this, we know now, was also Say's position. He never ceased to insist on a value index of riches. But this related specifically to the command of nominal income over goods and services - effectively a ratio of two sets of money values - such that a fall in cost prices entails an increase in real income. Any such 'increase' is, of course, necessarily somewhat arbitrary since all depends on the particular basket of goods and services appearing in the denominator.

\section{Capital accumulation: productive and unproductive consumption}

We consider in this section that aspect of the Malthus-Say debate turning on Malthus's definition in his Principles of 'riches' in terms of 'material objects which are necessary, useful or agreeable to mankind' (Malthus 1820: 28), and his representation of the cornerstone of the Wealth of Nations as the distinction between productive and unproductive labour, the former 'susceptible of accumulation' (44). From this perspective he rejected what he understood to be Say's position in the Traite that personal services be considered 'as equally productive of wealth with the labours of merchants and manufacturers', for were that the case it would be impossible to account for 'the increasing riches and prosperity of Europe since the feudal times' (35).

Say's response in his Lettres à M. Malthus reflected his view of production as entailing an exchange of immaterial services, the services of 'industry, capital, and land' which, 'independent of all matter, form all our revenues' (1821 [1820]: 17). Say expands in terms of conservation of matter:

What! all our revenues immaterial!!! Yes, Sir, ALL: otherwise the mass of matter which composes the globe would increase every year; it must happen so, for we should every year have new material revenues. We neither create nor destroy a single atom. All that we do is to change the combinations of things; and all that we add is immaterial. It is VALUE; 
and it is this value which is immaterial also, that we daily, annually consume, and upon which we live; for consumption is a change of form given to matter, or, if you prefer the expression, a derangement, as production is an arrangement of form.

Materiality as such could not be the issue, as Say puts it later, since it was "beyond the power of man, to add a single atom to the mass of matter of which the world is comprised' (76). ${ }^{11}$

Beyond this, Say protested in the Lettres that he had been misunderstood. He had never rejected susceptibility to accumulation in dealing with 'wealth' or 'riches', in the sense of capital (rather than real income which has concerned us so far). What mattered in this context was whether or not immaterial services are 'consumed' productively as intermediate consumption or unproductively as final consumption, the former alone entailing an accumulation process. (Apart from this, of course, productive consumption generates a surplus; see below, pp. 177-9.) ${ }^{12}$ He had certainly not considered 'personal services' as 'equally productive of wealth with the labour of merchants and manufacturers':

A domestic produces personal services which are wholly consumed unproductively by his master, as soon as produced. The service of the public functionary is in like manner wholly consumed by the public, as fast as it is produced. That is the reason why these different services contribute nothing to the augmentation of riches. The consumer enjoys these services, but cannot accumulate them. This is explained in detail in my 'Traité d'Economie Politique', 4e edition, tom. I, p. 124; and also in my Catechism of Political Economy. ... The wealth of Europe certainly does not arise from the strawberries which have been produced, because they must, like personal services, have been consumed unproductively as fast as they ripened, although less quickly than personal services.

I have instanced strawberries as a very perishable product; but it is not the durability of a production which particularly facilitates accumulation. It is because it is consumed in a manner adapted to reproduce its value in another object. For whether durable or not, every product is devoted to consumption, and answers no purpose whatever except by its consumption; this purpose is either to satisfy a want, or to reproduce a new value. When people undertake to write on political economy, they should dismiss from their minds the notion that durable produce accumulates better than what is perishable.

(18-19n.; emphasis added)

It was not then 'durability' or 'materiality' as such that mattered in facilitating accumulation but that consumption of a service be intermediate 'reproduc[ing] its value in another object'. But by the formulation in the 
Traité referred to in the foregoing citation, Say - who objected so strenuously to Malthus's 'materiality' condition - was asking for trouble by coining 'produits immatériels' as the term to describe the service sector:

De la nature des produits immatériels, il résulte qu'on ne saurait les accumuler, et qu'ils ne servent point à augmenter le capital national. Une nation où il se trouverait une foule de musiciens, de prêtres, d'employés, pourrait être une nation fort divertie, bien endoctrinée, et admirablement bien administrée; mais voilà tout. Son capital ne recevrait de tout le travail de ces hommes industrieux aucun accroissement direct, parce que leurs produits seraient consommés à mesure qu'ils seraient créés.

En conséquence, lorsqu'on trouve le moyen de rendre plus nécessaire le travail d'une de ces professions, on ne fait rien pour la prospérité publique; en augmentant ce genre de travail productif, on en augmente en même temps la consommation. Quand cette consommation est une jouissance, on peut s'en consoler; mais quand elle-même est un mal, il faut convenir qu'un semblable système est déplorable. ${ }^{13}$

(Say 1819a, 1: 124)

The Table Analytique sums up conveniently: 'Les produits immatériels sont les valeurs qui se trouvent nécessairement consommées en mêmes temps que produites'; '[l]es produits immatériels n'étant pas susceptibles de se conserver, ne peuvent s'accumuler'; '[e]n favorisant leur multiplication on ne fait rien pour la richesse' - read capital -'on ne fait que pour la consommation' (464).

In the passage from the body of the Traite cited above, Say treated the service sector including government as 'unproductive' from the perspective of capital accumulation. (The reference to 'employés' intends public servants as the qualifying term 'bien administrée' indicates.) But shortly thereafter some public services at least are represented as 'intermediate to the production of private marketed goods', as Boss put it (Boss 1990: 69). In fact, the second paragraph of the passage itself suggests that it is the excessive employment of public servants that Say excluded, though this condition applied to all activities (Say 1819a, 2: 124-6). Moreover, one notes the word 'direct' in the first paragraph - the services in question make no direct contribution to growth of capital leaving the gate wide open. And, in fact, one formulation given in the Traité treats government consumption, in principle, just as private consumption, specifying the generation of surplus in both cases as a condition for the designation 'productive':

Il n'y a pas ... deux sortes d'économie, qu'il n'y a deux sortes de probité, deux sortes de morale. Si un gouvernement comme un particulier font des consommations desquelles il doive résulter une production de valeur supérieure à la valeur consommée, ils exercent une industrie productive; si la valeur consommée n'a laissé aucun produit, c'est une 
valeur perdue pour l'un comme pour l'autre, mais qui, en se dissipant, a fort bien pu rendre le service qu'on en attendait.

We shall return to the issue of surplus presently (below, p. 177).

Malthus's first reaction to the Lettres was hostile. He wrote to Ricardo that he did not think it 'a very able performance', insisting again on distinguishing material goods from services: 'I cannot agree with him in making no distinction between services and products; in his strange and useless application of the term utility; in his opinions respecting the immateriality of revenues, and in his mode of reasoning' (25 September 1820; in Ricardo 1951-73, 8: 259-60). But in time he came to see that Say's accumulatability allowance was very close to his own materiality condition, having account of the explanation given by Say in his Lettres upon which we have been focusing:

The essential question in the definition of wealth is, whether or not it should be confined to material objects, and the reader is already apprised of my reasons for thinking that it should. Even M. Say, who admits 'les produits immatériels', allows, as I have before stated, that the multiplication of them 'ne fait rien pour la richesse'.

(Malthus 1986 [1827c], 8: 115)

The earlier passage here referred to is the following:

M. Say, though he calls the labour of the menial servant productive, makes a distinction between the labour which is productive of material products and the labour which is productive of immaterial products. Of the latter products he says, 'En favorisant leur multiplication, on ne fait rien pour la richesse, on ne fait que pour la consommation'. - Table Analytique [of the Traité , liv. I, ch. 13. This is a most characteristic difference; and though I prefer the classification of Adam Smith, as more simple, I should allow that, on these principles, the causes of the wealth of nations may be clearly explained. But I own myself utterly at a loss to conceive how they can be explained, if all labour be considered as equally productive.

(46n.)

Malthus is, at the close, too much taken with definition. Menial service is to be considered 'productive' for Say because it is scarce and productive of some use value. It is positively not 'productive' from the perspective of wealth (capital) creation.

The common ground between Say and the mainstream British writers extends to Say's formal objection to a materiality condition for 'production' running in terms of the non-creatibility of matter, which will be found 
expressed by James Mill in the form that labour can do 'nothing but produce motion. ... All that men can do is to place the objects of nature in a certain position' (Mill 1821: 5-6). And McCulloch - citing Destutt de Tracy - argued in very Sayian terms:

By production, in the science of Political Economy, we are not to understand the production of matter ... but the production of utility, and consequently of exchangeable value, by appropriating and modifying matter already in existence, so as to fit it to satisfy our wants, and to contribute to our enjoyments.

(McCulloch 1825 [1823]: 50)

J. S. Mill repeated his father's formulation (Mill 1963-91 [1848], 2: 27-8), and accepted also that 'what we produce or desire to produce is always, as M. Say rightly terms it, a utility', for labour 'is not creative of objects, but of utilities' (46). Yet, like Malthus, Mill too found the Say-McCulloch classification of all labour as 'productive' which is engaged in producing 'a benefit or a pleasure worth the cost' to be unhelpful from the point of view of wealth (capital) creation, Mill insisting on 'susceptibility to accumulation', for however short a period, as the feature distinguishing 'productive' from 'unproductive' labour from that point of view - the former 'fitting some other thing to afford a utility', the latter 'employed in producing a utility directly' (45-7). But this is precisely Say's position as we have shown. And from this perspective Mill - like Say - included within the 'productive' category the activities of merchants and dealers as well as transportation and a variety of other service workers engaged in wealth creation, expressing himself very much as did Say:

[Their labour] adds the property of being in the place where they are wanted ... which is a very useful property, and the utility it confers is embodied in the things themselves, which now actually are in the place where they are required for use, and in consequence of that increased utility could be sold at an increased price, proportioned to the labour expended in confirming it.

Conversely, labour engaged in the production of material goods renders a nation 'poorer' should 'the increase it makes in the stock of useful and agreeable things, be of a kind not immediately wanted' (52). There is full agreement with Say on these matters.

We continue our discussion by pointing to Say's inclusion in the Traité within 'capital productif' of the real-wage goods to be advanced to labour. 
The statement, which is reminiscent of Turgot (1997 [1766]: 188) and as strong as any to be found in the British literature, sets out by declaring that economic activity turns on the possession of existing stocks - 'des produits déjà existans' - specifically:

1. Les outils, les instrumens des différens arts....2. Les produits qui doivent fournir à l'entretien de l'homme industrieux, jusqu'à ce qu'il ait achevé sa portion de travail dans l'oeuvre de la production. Le produit dont il s'occupe, ou le prix qu'il en tirera, doit, à la vérité, rembourser cet entretien; mais il est obligé d'en faire [1819, 1826: continuellement] l'avance. 3. Les matières brutes que son industrie doit transformer en produits complets.

(Say 1814, 1: 22; 1817, 1:23; 1819a, 1: 23; 1826a, 1: 28-9)

Say's general notions of services and circular flow, on the other hand, point to purchases by labour at retail out of money earnings rather than the literal advance of real goods. The latter should, therefore, probably be understood only as a convenient fiction for analytical purposes. The more sophisticated and, empirically, the more meaningful view is beautifully outlined in the Lettres à M. Malthus in an account of the precise nature of 'productive consumption'; that wages are 'advanced out of capital' does not relate to the advance of real-wage goods:

Without this analysis, I defy you to explain the whole of the facts; for instance, how the same capital is twice consumed: productively, by a speculator [entrepreneur], and unproductively, by his workman. By means of the foregoing analysis, it may be seen how the workman brings to market his labour, the fruits of his ability; he sells it to the master, carries home with him his wages, which forms his revenue, and consumes it unproductively. But the master, who has bought the labour of the workman with a part of his capital consumes it reproductively, as the dyer consumes reproductively the indigo thrown into his copper. These values having been consumed reproductively, reappear in the production which comes out of the hands of the master. It is not the capital of the master which forms the revenue of the workman, as $\mathbf{M}$. Sismondi pretends. The capital of the master is consumed in the workshops, and not in the maintenance of the workman. The value consumed by the latter has another source; it is the produce of his industrious faculties. The master devotes to the purchase of the workman's labour a part of his capital. Having purchased it, he consumes it; and the workman consumes, on his part, the value which he has obtained in exchange for his labour. Wherever there is exchange, there are two values created and bartered one for the other; and wherever two values are created, there must be, and there are, in effect, two consumptions.

(Say 1821 [1820]: 18) 
The notion of a 'double consumption' entailed by capital accumulation the productive consumption by the entrepreneur of factor services and the unproductive (or final) consumption by service providers, including labourers - is expressed throughout the range of Say's writings (see in particular Book III, Chapter 3 of the Traité relating to 'la consommation reproductive'); but a particularly fine statement is given in the Commentary on Storch outlining the nature of capital accumulation. Capital grows despite the apparently paradoxical circumstance that there is no surplus of output over "consumption', for it is the category of consumption that is at issue, 'reproductive consumption' assuring the 'replacement' of 'advances':

comment croissent les richesses nationales? Elles croissent quand le possesseur d'une valeur, au lieu d'acheter des produits pour la satisfaction de ses besoins et de ses goûts, s'en sert pour acheter des services productifs qui lui procurent de nouvelles valeurs. Si je consacre six cents francs à mes besoins, cette valeur, une fois mes besoins satisfaits, n'existe plus pour moi ni pour personne. Si j'en achète six cents francs de journées d'ouvriers pour la faire travailler à la confection d'un produit, je capitalise cette somme; le capital de la société est augmenté de six cents francs; et cependant cette valeur sera consommée improductivement comme si je l'avais consacrée à mes besoins, puisque mes ouvriers et leurs familles la consacreront aux leurs, et consommeront pour six cents francs de produits en place de ceux dont je me suis abstenu. Dans un cas comme dans l'autre, la consommation brute aura été égale à la production brute; on n'a besoin de supposer aucun excédant pour trouver une augmentation de capital. D'où vient-elle donc cette augmentation? De ce qu'en employant ma somme à l'achat d'un travail je n'ai fait que l'avancer; elle a été aliénée par moi et consommée improductivement par les ouvriers; mais ces ouvriers m'ont créé par leur industrie un produit neuf, une nouvelle valeur qui a remplacé l'ancienne. Me trouvant ainsi remboursé de mes avances, je peux les recommencer de la même manière, et voilà un nouveau capital dans la société.

(Say $1848[1823] 321)$

However expressed, Say is expounding the dependence of demand for labour on capital expenditures or 'reproductive consumption', J. S. Mill's fourth 'fundamental proposition regarding capital' - 'the demand for commodities is not the demand for labour' (see above, p. 7) - which, Mill recognized, both Say and Ricardo had kept 'constantly and steadily in view' (Mill 1963-91 [1848], 2: $78,80)$. Say's enthusiasm for the matter goes back to 1803 :

Le public n'est donc point intéressé à la consommation qui se fait; mais il est intéressé et prodigieusement intéressé aux épargnes. Et, ce qui paraît extraordinaire à beaucoup de personnes, sans en être moins vrai, la classe industrieuse y est plus intéressée qu'aucune autre.

(Say 1803, 2: 362; emphasis added) 


\section{On surplus: gross and net revenue}

We have seen that 'reproductive' expenditure entails the creation of 'une nouvelle valeur' to replace values consumed in the production process: 'Me trouvant ainsi remboursé de mes avances, je peux les recommencer de la même manière, et voilà un nouveau capital dans la société.' But where in all this does the 'surplus' concept enter the picture, if at all?

We approach this issue by reference to a passage from the 1814 Traité which makes specific mention of a 'produit net': 'Quand on a déduit d'une valeur produite par l'industrie 1 . la valeur des avances qu'elle a exigées; 2 . la valeur du service industriel rendu, l'excédent de valeur qui reste, est un produit net, une richesse nouvelle introduite dans le monde' (Say 1814, 2: 188). A second passage insists on a potential net product - excess of returns over costs - in all sectors:

Ce produit net, s'il est ajouté aux consommations reproductives, est une addition à la masse des capitaux, des richesses de la société. Il est aussi réel, soit pour le producteur, soit pour la société, que celui que les économistes attribuaient à l'agriculture exclusivement. Qui empêche le commerce et les manufactures de créer plus de valeurs qu'ils n'en consomment? Si le produit net est fondé sur le concours gratuit des agens naturels, ces deux industries employent, elles aussi des agens naturels. Les profits capitaux tout entiers ne sont-ils pas un produit net?

That these passages are removed from later editions reflects Say's further thoughts on the issue, or at least his effort to be more specific (see note 2 above), summarized in a new entry 'Produit net, Produit brut' in the Épitome introduced in 1817 , which rejects the distinction at the aggregate level of conception:

PRODUIT NET, PRODUIT BRUT. La valeur produite est le produit brut; cette valeur, après en avoir déduit les frais de production, est le produit net.

A considérer une nation en masse, elle n'a point de produit net; car les produits n'ayant qu'une valeur égale aux frais de leur production, lorsqu'on retranche ces frais, on retranche toute la valeur des produits. La production nationale, la production annuelle, doivent donc toujours s'entendre de la production brute.

(Say 1817, 2: 469; 1819a, 2: 491-2)

The version in 1826 summarises the proposition with an extension to an open economy (1826a, 3: 313).

This denial of an aggregate surplus is shown in the body of the text in 1819 and 1826 to undermine the Physiocratic perspective: 
On voit par là que ce mot produit net ne peut s'appliquer qu'aux revenus de chaque entrepreneur particulier, mais que le revenu de tous les particuliers pris ensemble, ou de la société, est égal au produit brut résultant des terres, des capitaux et de l'industrie de la nation. Ce qui ruine le système des économistes du dix-huitième siècle, qui ne regardaient comme le revenu de la société, que le produit net des terres, et qui concluaient que la société n'avait à consommer qu'une valeur égale à ce produit net; comme si la société n'avait pas à consommer tout entière une valeur qu'elle a créée tout entière.

(Say 1819a, 2: 74; 1826a, 3: 238)

Say does not mention any discord with the Ricardians on the matter. But Ricardo did add a note to his third edition pointing to the disappearance with Say of a net product:

Of net produce and gross produce, M. Say speaks as follows: 'The whole value produced is the gross produce; this value, after deducting from it the cost of production, is the net produce'. . . There can then be no net produce, because the cost of production, according to M. Say, consists of rent, wages, and profits.

(Ricardo 1951-73, 1: 421n.)

Ricardo bases himself here on our citation from the Épitome (Say 1819a, 2: 491), but he also refers to Say's further formulation, 'The value of a product, the value of a productive service, the value of the cost of production, are all then similar values, whenever things are left to their natural course' (Say 1819a, 2: 508), adding: 'Take a whole from a whole, and nothing remains.'

It will be recalled that Ricardo himself, earlier in his text, had accepted this very formulation, exception made for rent: 'M. Say maintains with scarcely any variation, the doctrine which I hold concerning value. In his productive services, he includes the services rendered by land, capital, and labour; in mine, I include only capital and labour, and wholly exclude land' (above, p. 59). Even so, we do not get to grips with the main issue by approaching the matter in these terms, for Ricardo's insistence on the net-gross distinction at the economy-wide level extends beyond the rental income, relating as it does far more generally to disposable income: 'It is of importance to distinguish clearly between gross revenue and net revenue, for it from the net revenue of a society that all taxes must be paid' (Ricardo 1951-73, 1: 421). We have seen also that in the chapter devoted to 'Gross and Net Revenue', Ricardo excluded wages from the net component if at their minimum and constituting 'the necessary expenses of production', but allowed - in response to Say's Note of 1819 on the issue - that should wages, as was 'generally' the case, exceed minimum expenses then 'a part of the net produce of the country is received by the labourer, and may be saved or expended by him; or it may enable him to contribute to the defence of the 
country' (above, p. 70). In fact, the Advertisement to the 1821 edition of the Principles presses the point home with a vengeance - 'surplus' can appear in any real income:

I have endeavoured to shew, that the ability to pay taxes, depends not on the gross money value of the mass of commodities, nor on the net money value of the revenues of capitalists and landlords, but on the money value of each man's revenue, compared to the money value of the commodities which he usually consumes.

Now there is absolutely nothing here at odds with Say, who of course retained a notion of disposable income. It is of high interest to find at one point in the Cours complet net income identified with 'profit' - in this context in the sense of interest on capital, the entrepreneur coalescing with the capitalist - since that particular income might be consumed unproductively without eating into capital:

Un capital consommé pour la reproduction, doit être considéré sous deux rapports: sous le rapport des produits qui le composent, et sous le rapport d'un fonds permanent qui se perpétue et qui peut servir à plusieurs productions successives. Sous le premier rapport, les produits sont détruits par la consommation; et de leur valeur il ne reste rien. Sous le second rapport, le capital n'est pas détruit; puisque sa consommation n'a été qu'une avance qui se trouve remboursée par les opérations productives. C'est un fonds permanent dont l'entrepreneur d'industrie, que je considère ici comme capitaliste et maître du capital, ne recueille aucune jouissance, mais qu'il conserve. Le seul avantage qu'il en retire, c'est le salaire du service rendu par ce fonds, c'est-à-dire le profit, l'intérêt du capital; et ce profit, étant une nouvelle valeur, peut être consommé improductivement par lui, sans que son fonds en reçoive aucune diminution.

(1843 [1828-9]: 405; emphasis added)

In other contexts, surpluses seem to be identified with the return to entrepreneurship more narrowly defined.

\section{Taxation and economic activity ${ }^{14}$}

The Traité provides a statement of the general principle that taxation - at least if 'pushed too far' - reduces private 'riches' without enriching the state:

Lorsqu'il est poussé trop loin, il produit ce déplorable effet de priver le contribuable de sa richesse sans enrichir le gouvernement; c'est ce qu'on pourra comprendre, si l'on considère que le revenu de chaque contribuable offre toujours la mesure et la borne de sa consommation, 
productive ou non. On ne peut donc lui prendre une part de son revenu sans le forcer à réduire proportionellement ses consommations. De là, diminution de demande des objets qu'il ne consomme plus, et nommément de ceux sur lesquels est assis l'impôt; de cette diminution de demande résulte une diminution de production, et par conséquent moins de matière imposable. Il y a donc perte pour le contribuable d'une partie de ses jouissances, perte pour le producteur d'une partie de ces profits, et perte pour le fisc d'une partie de ces recettes.

(Say 1814, 2: 300; 1817, 2: 309; 1819a, 2: 337; 1826a, 3: 155)

To this argument Ricardo objected in 1817 that Say neglected the compensatory government expenditures financed by the tax which assured against the deflationary outcome envisaged - there were enough objections to taxation without adding to them, he pointed out in one of the few light moments in the debate (Ricardo 1951-73, 1: 237).

Responding in the Notes of 1819 to Ricardo's position whereby factors expelled from an industry by taxation are reabsorbed elsewhere, as a result of expanded government expenditure, ${ }^{15}$ Say focused on Ricardo's alleged neglect of friction in the transition process - immobilities of various sorts generating capital losses in the industrial sector (Say 1819b: 1: 418). ${ }^{16}$ To this he added that wage and entrepreneurial income yielded in other sectors, even supposing a full transfer of resources is possible, will necessarily be lower than originally:

Et en supposant qu'ils aient pu se transporter ailleurs, et apprendre un autre métier, le revenu de leurs bras en a nécessairement souffert; il y a eu moins de gains faits par leurs travaux industriels; quant aux chefs de cette industrie, en supposant même qu'ils n'aient pas renoncé entièrement à une production devenue trop ingrate, ils auront du moins réduit leur exploitation; leurs bénéfices n’auront plus été les mêmes.

Now no adequate justification is offered for the proposition that incomes generally fall even when factors can transfer to other sectors. ${ }^{17}$ As Ricardo pointed out in another context (Ricardo 1951-73, 1: 392-3), wages might actually rise on average with increased expenditure on labour-intensive government services. (On the general principle involved, see above, p. 5.) But with this assertion Say closes his case:

Ce ne sont donc pas seulement des capitaux et une industrie qui changent de place, mais des capitaux et une industrie diminués et produisant moins. J'ai donc pu dire que lorsque l'impôt est poussé trop loin, il y a des pertes de jouissances et de revenus dont le gouvernement ne fait pas son profit.

(Say 1819b, 1: 418-19) 
That, pace Ricardo, taxation necessarily reduces national income (not merely when it is pushed 'too far') by forcing a redistribution of activity is a central theme in the Traité of 1819:

Cette doctrine a été combattue par M. David Ricardo [1951-73, 1: 237]. Il prétend que l'industrie et ses produits étant toujours en raison de la somme des capitaux employés, si un impôt détruit une certaine industrie, ses produits sont remplacés par une autre, vers laquelle se reportent et les travaux et les capitaux demeurés vacans. Je répondrai qu'un impôt qui change l'emploi des capitaux, fait perdre les profits que rendaient ceux qui se trouvaient engagés, et qu'il diminue les profits de ceux qui ne l'étaient pas; car leur emploi devait être le plus lucratif, puis-qu'on le préférait. J'ajouterai qu'un changement de direction imprimé forcément à la production, fait perdre encore beaucoup de profits industriels.

(Say 1819a, 2: 342n.)

Say adds a general objection to government activity as such, not hesitating to attribute Ricardo's position to faulty method:

Enfin, est-ce la même chose pour la prospérité publique, que ce soit un particulier qui consomme ses revenus, ou que ce soit l'état? Une industrie florissante et lucrative facilite l'accumulation et la formation de nouveaux capitaux; une industrie contrariée par l'impôt, fait qu'on travaille défavorablement: loin d'accroître son capital, on l'entame, on s'appauvrit, la production diminue, les charges demeurent, et la prospérité s'en va. M. Ricardo procède par principes absolus, comme on ferait en géométrie. En économie politique, c'est une méthode dangereuse, et dont il faut se méfier.

A corresponding statement is found in a footnote elaborating empirical instances allegedly showing that government revenues increase by less than the tax burden imposed, such that net expenditure necessarily falls short:

Ces deux derniers exemples répondent suffisamment à $\mathrm{M}$. Ricardo, qui attaque ce passage du texte, en disant que l'impôt ne nuit pas à la production générale, par la raison que le gouvernement se rend consommateur d'une valeur équivalente à celle qu'il ravit au contribuable. Si ce qu'il ravit au contribuable n'augmente pas sa recette, il diminue la demande qu'aurait fait le contribuable sans augmenter la sienne.

A revised version of this footnote for the 1826 edition restates the objection:

Ricardo a attaqué ma doctrine sur ce point. Il croit que l'impôt du sel réduisant à moitié la quantité de cette denrée qui pouvait se produire et se consommer, sa production employait moitié moins de capitaux, et 
que l'autre moitié des capitaux était dès-lors appliquée à une autre production. Mais l'impôt agit comme une augmentation de frais de production, d'où il résulte qu'avec le même capital, on obtient moins de produits.

(1826a, 3: 157n.)

Ricardo's error is once more traced to 'abstract' method, and he is even accused of at least implying a tolerance of 'regulation':

D'ailleurs je suis loin de regarder comme un fait ce principe fondé sur une abstraction, que la production est nécessairement proportionnée aux capitaux. En supposant que l'impôt n'eût même d'autre effet que de tirer les capitaux d'un emploi, pour obliger leurs propriétaires à les employer dans un autre moins avantageux, n'est-ce donc point un mal? Que fait de pis le système réglementaire, contre lequel Ricardo luimême s'élève avec tant de raison?

But Say appears to carry his objections yet further. Even supposing total expenditure to be maintained by government purchases out of tax revenues, there remained a problem. We illustrate from the Lettres à M. Malthus:

taxes do not augment the profits [incomes] of the producer, although they increase the price of every production: the incomes of the producers become insufficient to purchase the produce, the moment its price is raised by the circumstances which I have just described.

(1821 [1820]: 46)

To Ricardo's objection that tax revenues are ultimately spent by public functionaires, soldiers, etc., Say responded that such expenditures are 'entirely at the expense of the producers' (48). A convenient summary is provided in the Cours complet of the proposition that though there may be no net fall in expenditure the problem yet remains:

Ricardo et ses partisans m'opposent que les frais sont remboursés par les consommateurs, et que l'impôt ne diminue pas leur nombre; car la consommation de ceux qui vivent de l'impôt remplace celle que les contribuables sont obligés de s'interdire. Mais on a vu que l'impôt n'augmente pas la somme des revenus; qu'il ne fait que substituer un consommateur à un autre, que donner à Paul le revenu de Pierre; et qu'avec une somme de revenu qui n'est pas augmentée, il est impossible d'acheter la même quantité de produits, lorsqu'ils ont nécessairement augmenté de prix.

(Say 1843 [1828-9]: 510)

In the final resort, Say's analysis implies that only 'regular' production costs have an income counterpart - in effect, income is generated only in 
the private or productive sector - whereas taxes, which appear as a cost to private entrepreneurs, do not. Required for Say would be an increase in income and thus in net expenditure to compensate for the taxes, which increase is not forthcoming. On this view of the matter, incomes are necessarily 'insufficient to purchase the produce' in the language of the Lettres (though we have also seen that Say sometimes expresses a concern only when taxation is 'pushed too far'). Ricardo by contrast, though he accepted Say's basic 'doctrine of services' (see p. 59), and in the standard manner contrasted between 'productive' and 'unproductive' activity, did not draw the same strong conclusions regarding the effect of taxation on overall expenditure.

Notwithstanding this contrast, there remained much common ground that Say failed to recognize. There is a mutual concern with the potentially damaging impact of taxation on taxable capacity, even on the source of income in extreme cases. As for Say:

On a quelquefois appelé revenu d'une nation, le montant de ses contributions. Cette expression n'est pas exacte. Les particuliers paient leurs contributions avec leur revenu; mais les contributions ne sont pas un revenu. Elles sont un tribut imposé sur les revenus, et malbeureusement quelquefois sur les capitaux.

(1819a, 2: 75n.; emphasis added)

In Ricardo's exposition:

Whether taxes be taken from revenue or capital, they diminish the taxable commodities of the State. If I cease to expend $100 l$, on wine, because by paying a tax of that amount I have enabled Government to expend $100 l$. instead of expending it myself, one hundred pounds worth of goods are necessarily withdrawn from the list of taxable commodities.

(Ricardo 1951-73, 1: 238-9)

Moreover, taxation diminishes the motive to accumulate and may even lead to decumulation (185). Beyond this, Say's complaint that Ricardo neglected the immobility problem in his taxation analysis is baseless. Ricardo devoted his chapter 'Sudden Changes in the Channels of Trade' to transitional problems of the sort Say elaborated; he interpreted the post-war depression in terms of capital immobility, recognizing the likelihood of capital loss at least in the case of machine-intensive industry (266); and the transitional problem governed his recommendation for corn-law reform in a manner allowing the gradual withdrawal of capital from the land (266-7). But there was no special need to spell them out in the taxation context when dealing with matters of principle.

Important though this degree of commonality is, Ricardo emerges as the calmer of the two on taxation, for Say was prone to take a rather catastrophic 
view of its consequences, illustrating perhaps what Forget refers to as 'the fundamental concern of the idéologues with social stability' (Forget 1999: 175). ${ }^{18}$ Yet even he admitted counteracting pressures reflecting impressive growth of knowledge and 'industrial activity', as in his Notes of 1819 where - as in other instances - looseness of argument is revealed in his assertions that it is not always the case that capital is forced into a less favourable direction by taxation and that it is only exaggerated impositions that are objectionable:

un commerce grevé d'impôts exige, en proportion des quantités produites, plus de capitaux; en second lieu ... une partie des capitaux sortent évidemment d'un emploi qui devient moins avantageux, sans que ce soit toujours pour se porter sur d'autres productions également favorables au bien-être de la société; et . . . ils en sortent aussi pour être voués à la consommation improductive, à la destruction.... [Les gouvernemens] rendent d'une part la production désavantageuse par des impôts exagérés, et d'autre part offrent complaisamment aux producteurs de dévorer à la suite d'un emprunt les capitaux qui, par leur faute, rendent trop peu entre les mains de l'industrie. Le vice nourrit le vice; et s'il n'y avait pas maintenant en Europe, dans le monde entier, un développement de connaissances et d'activité industrielle supérieure à tous les exemples que nous fournissent les temps historiques, un développement qui fait plus que balancer les maux qui résultent de la maladministration, il ne tiendrait pas à la politique européenne que la civilisation du monde rétrogradât on ne sait où.

(Say 1819b, 1: 382-3; emphasis added)

\section{The gains from trade}

We turn briefly to the index of national gain derived from trade, a matter on which there is, to begin with, a difference of opinion between Ricardo and Say. A passage in the Traité of 1814 (Say 1814, 1: 401) that caught Ricardo's eye takes the utility index as measure of the gains from domestic commerce, whereas an upward adjustment is required in the case of foreign commerce to include profits on that trade; in Ricardo's translation:

the profits which merchants make by their dealings with their countrymen, as well as those which are made in the exclusive commerce with colonies, are not entirely gains for the State. In the trade between individuals of the same country, there is no other gain but the value of an utility produced; que la valeur d'une utilité produite.

(Ricardo 1951-73, 1: 318)

For Ricardo, the utility gain is the index of national advantage on all trade, external as well as internal: 'The advantage always resolves itself into that 
which M. Say appears to confine to the home trade; in both cases there is no other gain but that of the value of an utilité produite' (320).

Say's Note of 1819 on this passage defends his contrast on the grounds that profits made by merchant $\mathrm{X}$ at the expense of $\mathrm{Y}$ engaged in internal trade cancel out in a national calculation:

Outre les gains qu'on peut faire par le moyen d'une utilité, et par suite d'une valeur produite, on peut faire son profit des pertes d'un autre homme. Lorsque cet autre homme est un compatriote, la nation ne perd ni ne gagne par ce bénéfice porté d'une poche dans l'autre; lorsque cet autre homme est d'un autre pays, la nation dont le premier fait partie, gagne ce que l'autre nation perd. Je ne prétends pas justifier ce gain; je me borne à établir le fait.

(Say 1819b, 2: 167)

He does not respond to Ricardo's observation (Ricardo 1951-73, 1: 318-19n.) that this position conflicts with Say's (Smithian) investment priorities, whereby the bome trade is 'the most profitable' since '[t]he commodities exchanged in that trade are necessarily the productions of the same country' (Say 1814, 1: 84); or whereby 'the most profitable sales are those which a country makes to itself, because they cannot take place, without two values being produced by the nation; the value which is sold, and the value with which the purchase is made' (221).

Now the contrast between the gain from domestic and foreign trade is to be found repeated in all later editions of the Traité $(1817,1: 396 ; 1819 \mathrm{a}, 1$ : $424 ; 1826$ a , 2: 131-2), with a helpful modification introduced in 1819. For the reference to colonial trade as equivalent to internal trade is then replaced, to read simply: 'car les gains que font les négocians sur leurs compatriotes, par un monopole, ne sont pas en totalité des gains pour l'état' (emphasis added). Thus the purported contrast is said to apply only in the special case of monopoly. In competitive conditions - so one is left to deduce - such opportunities would not exist in either foreign or domestic commerce rendering both equivalent, just as Ricardo had it as far as concerns the national gain in terms of 'une utilité produite'.

The investment-priorities classification of industries, on the other hand, remains the same in all later editions $(1817,2$ : 131-2; 1819a, 2: 156-7; 1826a, 2: 341-2). And this Smithian analysis certainly does constitute a major exception to Say's 'canonical' bonâ fides.

\section{Summary and conclusion}

For Ricardo, a value measure of 'riches' was irrelevant, all that mattered being the flow of 'production' or real income and thus of 'happiness'. Thus with respect to the welfare objective of free trade - the same applies to new technology - we read: 'the end of all commerce is to increase production, 
and ... by increasing production, though you may occasion partial loss, you increase the general happiness' (1957-73, 1: 271); 'to augment the produce ... is the end; of what importance can it be to the society, whether half its capital be sunk in value, or even annihilated, if they obtain a greater annual quantity of production?' (269n.). Ricardo could envisage no way of measuring 'riches' thus conceived: 'One set of necessaries and conveniences admits of no comparison with another set; value in use cannot be measured by any known standard; it is differently estimated by different people' (429).

Now it was Say's belief that Ricardo also included free goods within riches, a misattribution that seriously clouds the debate. He himself wrote in 1822 that this matter alone stood between them:

Tout ce qui nous empecherait d'être d'accord serait donc que vous voulussiez meler dans les considérations d'Economie politique aux richesses sociales (ou valeurs échangeables) les richesses naturelles (ou ces utilités qui ne sont le fruit d'aucuns services productifs et que Smith appelle value in use).

(1 May 1822; in Ricardo 1951-73, 9: 190)

But this is precisely the Ricardian position which insists that the relevance of costs to pricing lies in their determining supply constraints relative to demand, in the absence of which a good is excluded from 'riches'. That this is so emerges clearly in Ricardo's rejection, in a letter to Malthus, of a contention by Louis Say (1822) that the British economists and J.-B. Say all neglected the scarcity property of valuable goods:

[J.-B. Say's] brother Louis Say has published a thick volume of remarks upon Adam Smith's, his brother's, your and my opinions. He is not satisfied with any of us. His principle object is to shew that wealth consists in the abundance of enjoyable commodities, - he accuses us all of wishing to heap up what we call valuable commodities, without any regard to quantity, about which only the Polit. Economist should be anxious. I do not believe that any of us will plead guilty to this charge. I feel fully assured that I do not merit it should be made against me.

(16 December 1822; Ricardo 1951-73, 9: 248-9)

It is no accident that Say and Ricardo gave identical responses to the position of Lauderdale (1804) that national wealth increases when a hitherto free good becomes scarce. 'Il est tout entier fondé sur cette proposition erronée', Say protested, 'que la disette d'une denrée qui diminue les ressources de la société, prise en masse, augmente celle des particuliers, en augmentant la valeur de cette denrée entre les mains de ceux qui en possèdent' (1814, 2: 38n.; 1817, 2: 45n.; 1819a, 2: 47n.; 1826a, 2: 191n.). Ricardo had reached precisely the same conclusion as we have seen at the outset of this chapter (above, p. 147). 
But the main source of confusion in the debate is Say's frequent practice of transferring to a Ricardian notion of 'riches' in product or total utility terms in the course of resolving the 'thorny' problem that with reductions in cost price in consequence of new technology, riches, albeit a value concept, rise rather than fall. They do so in the specific sense of increased command by income recipients over real goods, that is an increased flow of real income - 'richesserevenu', 'richesse-nouvelle', 'richesse-réelle' and 'jouissance' are the terms used. In this manner Say sought to reconcile an exchange with a utility perspective on 'riches', effectively ending up by perceiving riches as real income.

When all is said and done, the whole dispute is unreal. Say himself already makes it clear in his Notes of 1819 that there was accord between all participants in the debate on the principal issue of what riches consist and upon what riches depend:

Ce qu'il y a de vraiment important dans l'Économie politique, c'est de savoir en quoi consistent les richesses, par quels moyens elles se multiplient et se détruisent; et sur ces points essentiels Smith, Buchanan, Malthus, Ricardo et Say sont heureusement d'accord.

(Say 1819b, 1: 419-20)

We have seen too the letter to Ricardo dated 19 July 1821 (above, p. 158), where Say points to shared opinion regarding policy. By this he intended the productivity benefits flowing from technological progress and free trade, as is nicely encapsulated in the Epitome under CONSOMMATEUR in 1819:

Un peuple tout entier devient plus riche par rapport à un objet de consommation, quand cet objet peut être acquis à moins de frais, et vice versâ. L'objet est acquis à moins de frais, lorsque l'industrie, dans ses progrès, parvient à tirer plus de produits des mêmes moyens de production. Alors on a généralement plus d'utilité à consommer, sans avoir fait plus de frais pour l'obtenir. Tout ce qui tend à multiplier les produits d'une nation, tend par conséquent à l'enricher.

(Say 1819a, 2: 460; cf. also 1814, 2: 440; 1817, 2: 435-6) ${ }^{19}$

This is a wholly Ricardian formulation, Say making no mention of riches as a value concept.

We recall now Say's original insistence that to measure 'riches' in value terms provided a 'scientific' basis for a quantitative treatment which is precluded by Ricardo's utility index (above, p. 79). This we have found turns out to apply to the valuation of an existing stock subject to correction for changes in the purchasing power of the monetary medium (see above, p. 150). It did not extend to statistical comparisons of real income over time and space. Thus consider the statement in 1819 that ' $[1\}$ a valeur du revenu est ... d'autant plus considérable qu'on obtient, non pas une plus grande valeur en produits, mais une plus grande quantité de produits, une plus grande 
masse d'utilité produite' (cited above, p. 154). To this wholly Ricardian statement is attached a note precluding international comparisons precisely because real national income relates to utility or 'bien-être', not to value:

On voit combien il est superflu de vouloir comparer le revenu de deux nations, de la France et de l'Angleterre, en comparant la valeur de leurs produits annuels. En outre, il n'y a aucune parité possible entre deux valeurs qui ne sont pas dans le même lieu. La comparaison de la richesse de deux peuples ne peut se faire que par une appréciation morale du bien-être de l'un et de l'autre.

(1819a, 2: 26n.)

Or again, in the Epitome under RICHESSE we find the strong denial of meaningful statistical measures of international real-income comparisons; only approximate welfare rankings could be hoped for, allowance made for distributive considerations:

Cela montre qu'on ne peut compter sur aucun résultat positif, en comparant la statistique d'un pays avec celle d'un autre. La comparaison de la richesse de deux nations est la quadrature du cercle de l'économie politique. Il faut se contenter de savoir que la nation chez qui les produits à consommer, sont, en général, le plus abondans par rapport à la population, et où les produits se distribuent le mieux en proportion de la part que chacun a prise à la production, est celle où l'on est le mieux accommodé, ou l'on jouit de plus d'aisance.

(Say 1819a, 2: 503)

The substance of these wholly Ricardian statements appears in the 1826 version with only slight modification (1826a, 2: 224-5). 


\section{The Law of Markets}

\section{Introduction}

Evidence for the Law of Markets is often drawn by Say from the secular record extending over centuries, suggesting a proposition to the effect that there are no constraints on long-term growth emanating from inadequacy of aggregate demand. Certainly he rationalized the rapid spending of sales proceeds, creating a presumption against an excess demand for money to hold even in the short run. On the other hand, in his later writings in particular, he recognized aggregate-demand contraction as one source of depression and general unemployment, going beyond Ricardo who allowed only that inadequate demand for goods characterized depression brought about by monetary or credit contraction. And while enthusiastically accepting Ricardian monetary principles, he objected to the 'Treasury View' perspective, regarding the capital constraint as flexible - firms quite commonly holding reserve funds - very much as J. S. Mill was to do (Mill 1963-91 [1844]). Particularly striking are allusions to the consequences for general output and employment of aggregate-demand fluctuations that characterize advanced manufacturing; an interpretation of the French industrial depression of 1813 as the outcome of contraction of demand for manufacturers emanating from the agricultural sector; and allowances that in periods of deflationary expectations the concern of investors to avoid loss of interest characterizing quiescent times gives way, generating excess demand for money to hold.

\section{Say's first statement, 1803}

The first edition of Say's Traité d'économie politique contains a brief chapter entitled 'Des Débouchés' - better translated as 'on outlets for goods' rather than 'on markets' (Baumol 1977: 147) - (Book 1, Chapter 22). ${ }^{1}$ The argument commences with the observation that it is the excess outputs of commodities over their producers' own requirements which generate mutual outlets or débouchés for each other. In this context, Say implies that no attempt it made to add to money balances from sales proceeds, money serving merely as the medium of exchange: 
La monnaie sert dans cette opération à-peu-près de la même manière que les affiches et les feuilles d'avis qui, dans une grande ville, opèrent le rapprochement des gens qui sont dans le cas de faire des affaires ensemble. Au bout de l'année chaque producteur a manié une très-grande quantité d'argent, mais sauf quelques soldes de peu de conséquence, il ne lui reste ordinairement pas entre les mains plus d'argent comptant à la fin de l'année qu'il n'en avait au commencement. L'essentiel est ce qu'il achète avec cet argent, c'est-à-dire les produits des autres qu'il a échangés avec les siens, et dont il a consommé une partie et conservé l'autre, selon ses besoins, son économie et l'état de sa fortune.

Ceci montre, j'espère, que ce n'est point tant l'abondance de l'argent qui rend les débouchés faciles, que l'abondance des autres produits en général. C'est une des vérités les plus importantes de l'Economie politique.

(Say 1803, 1: 152-3)

Sales opportunities thus depend upon the ability to purchase, which in turn is governed by production or real output. In the exchange process 'l'argent ne remplit qu'un office passager.... Les échanges terminés, il se trouve qu'on a payé des produits avec des produits' (154). In a later formulation, the general unimportance of the mercantilist concern with the adequacy of the money supply is made on the same Hume-like grounds that had been adopted by Smith:

La nation est intéressée à produire beaucoup, à vendre beaucoup de productions au-dehors, à fin de recevoir une grande quantité de productions en échange des siennes; du reste peu lui importe qu'on l'a payé en argent ou en marchandise. Si l'argent vient à manquer chez elle il en entrera naturellement parce que l'argent s'élèvera à un prix tel, qu'il sera plus lucratif d'y envoyer cette denrée-là qu'une autre.

Whether or not Say intended to rule out short-run excess commodity supply, or temporary excess demand for money, is the problem we shall throughout keep in mind. The point to note is that, at this stage, the possibility of excess commodity supply is recognized though there is little to suggest that it was envisaged as the consequence of an excess demand for money, since the solution is found in the production of a second commodity: 'quand une nation a trop de produits dans un genre, le moyen de les écouler est d'en créer d'un autre genre' (154). The correction involves not a transfer of resources from industries in excess supply but rather net expansion of those industries once markets are opened up for them by production of 'counter-commodities', a term commonly used for the doctrine.

Additional materials that were subsequently gathered within a single, extended, chapter on 'Des Débouchés' are in 1803 presented in two chapters devoted to the questions: 'Suivant quelles proportions la valeur des produits 
se distribue entre les trois sources de production' (Book IV, Chapter V), and 'Si un état s'enrichit par ses Consommations' (Book V, Chapter III). In the first of these chapters Say observed that the level of expenditure depends upon the level of general activity. Even more strongly he concluded that 'la demande des produits en général est donc toujours égale à la somme des produits', putting paid to doctrines that relate the level of activity to (unproductive) consumption outlays:

L'étendue de la demande des moyens de production en général, ne dépend pas, ainsi que trop de personnes l'ont imaginé, de l'étendue de la consommation. La consommation n'est point une cause: elle est un effet. Pour consommer il faut acheter; or on n'achète qu'avec ce qu'on a produit. La quantité de produits demandés est-elle donc determinée par la quantité de produits créés? Sans aucun doute. Chacun peut à son gré consommer ce qu'il a produit; ou bien avec son produit en acheter un autre. La demande des produits en général est donc toujours égale à la somme des produits. . . . On voit que le meilleur moyen d'ouvrir des débouchés aux produits est de les multiplier et non de les détruire. Si ce résultat est évident, comme je le crois, que penser des systèmes où l'on encourage les consommations pour favoriser la production. ${ }^{2}$

(Say 1803, 2: 175-6)

Subsequently, Say charged the Physiocrats with confusing the order of causality and recommending high consumption as a means of encouraging production (358-9).

Now, in a rendition of Smith's savings-is-spending doctrine (Smith 1937 [1776]: 321) the process of accumulation itself is said to create no special problems since accumulation implies expenditure as much as does (unproductive) consumption: 'Le débouché n'est-il pas trouvé par cette accumulation, aussi bien que si la même valeur avait été consommée?' (Say 1803, 2: 176-7), to which is appended a note to the effect that 'la partie épargnée sur les revenus et ajoutée aux capitaux, est également consommée chaque année, mais d'une autre façon ... d'une façon reproductive' (177n.). The limits to output are, consequently, solely those imposed by capacity: 'Elles sont dans les moyens de produire' (177).

The argument is carried a step further. Since accumulation results in expanded capacity the consequence thereof is a concomitant expansion of the market; and tribute is paid to the social advantage of saving:

En effet elle voit grandir chaque année les profits de ses capitaux et le pouvoir de son industrie, ses revenus par conséquent; c'est-à-dire ses moyens de consommer soit directement, soit par échange; en un mot ses débouchés. Le public n'est donc point intéressé à la consommation qui se fait; mais il est intéressé et prodigieusement intéressé aux épargnes. 
It is highly problematic that Say also subscribed to the notion of a falling return on capital with accumulation and increased production: "car les profits des capitaux ne peuvent baisser sans qu'il y ait une plus grande quantité de capitaux jetée dans la circulation ...' (189; see also 183). Ricardo was to complain of serious inconsistency on the part both of Smith and Say in this regard (above, p. 64).

As in the brief chapter 'Dés Débouchés', Say also raises the issue of excess supply, but now the solution runs explicitly in terms of the transfer of resources from the commodity initially in excess to some commodity in short supply (rather than a net expansion of the latter raising demand for the former in consequence):

Mais, dit-on, s'il y a de la merchandise qui ne trouve pas d'écoulement, il y a nécessairement plus de moyens de produire employés, qu'il n'y a de facultés pour consommer leurs produits. Nullement; l'engorgement n'a lieu que lorsqu'il $\mathrm{y}$ a trop de moyens de production appliqués à un genre de production et pas assez à un autre. En effet qu'est-ce que le défaut d'écoulement? C'est la difficulté d'avoir une autre marchandise (denrée ou argent) en échange de celle qu'on offre. Les moyens de production manquent donc à la première autant qu'ils sont surabondans pour la seconde. Un canton de l'intérieur des terres ne trouve pas d'écoulement pour ses blés; mais s'il s'y établit une manufacture, et qu'une partie des fonds et de l'industrie qui se dirigeaient vers la culture de la terre, se dirige vers un autre genre de production, les produits de l'une et de l'autre espèce s'écouleront sans peine, quoique les produits aient plutôt augmenté que diminué. Le défaut d'écoulement vient donc non de la surabondance, mais d'un emploi défectueux des moyens de production.

The corrective transfer of resources between sectors in what amounts only to partial excess supply, it is further maintained, would be made rapidly; and the concession did not disturb the principal theme that expansion of output cannot outrun purchasing power, but simply introduced the condition that the mix of commodities be appropriate to the pattern of demand:

Je conçois que la circulation peut être obstruée par de certains produits trop abondans; c'est un mal qui ne peut jamais être que passager, car on cesse bientôt de se livrer à une production, dont les produits excèdent les besoins et tombent dans l'avilissement, pour s'occuper de la production des denrées recherchées; mais je ne conçois pas que les produits de l'industrie d'une nation en général, puissent jamais être trop abondans, car l'un donne les moyens d'acheter l'autre. La masse des produits compose la masse des richesses d'une nation; et les richesses sont une chose dont les nations ne sont pas plus embarrassées que les particuliers. 
The sole empirical support offered for the proposition that output in general can never be in excess is the secular record:

Ce point bien éclairci, nous fournit une réponse à la question qui nous occupe et que je reproduis: A quoi tient la demande des moyens de production en général? Elle tient à l'étendue de la production. Et comme l'étendue de la production dépend de l'étendue des moyens de production, la demande des moyens de production s'étend dans la même proportion que les moyens de production eux-mêmes; c'est-à-dire en résultat, qu'une nation a toujours les moyens d'acheter tout ce que'elle produit. Autrement comment ferait-on pour acheter en France deux ou trois fois plus de choses, au moins, qu'on n'en achetait sous le règne misérable et infortuné de Charles VI [1368-1422]?

We have arrived at the argument supported by secular evidence that a nation has the ability to absorb any level of aggregate output. That it has the will to do so, which is evidently also seen to be reflected in the secular record, is rationalized in behavioural terms, hoarding represented as irrational in the light of loss of interest, with nothing said of 'precautionary' or other motives for holding money stocks: 'Le meilleur des encouragemens pour la circulation, est le désir que chacun a, surtout les producteurs, de ne perdre que le moins possible l'intérêt des fonds engagés dans l'exercice de leur industrie' (136). Say also briefly considers episodes illustrated by the assignats where inflationary expectations assure rapid disbursement of money funds:

C'est en partie ce motif qui fut cause de la prodigieuse circulation qui eut lieu pendant que le discrédit des assignats allait en croissant. Tout le monde était ingénieux à trouver un emploi pour un papier-monnaie dont la valeur s'évaporait d'heure en heure. On ne le recevait que pour le placer. Il semblait qu'il brûlât quiconque le touchait.

Say gives a remarkable account of the construction of industrial plant, house repairs and the like undertaken during the episode in question. Nonetheless, apart from such exceptional periods, it is avoidance of loss of interest on which he relies to rationalize rapid disbursement of money funds.

Under normal circumstances hoarding is thus ruled out as irrational. On the other hand, under circumstances of political instability and uncertainty, and expectation of general price deflation, the phenomenon took on great importance and was in fact the source of, or at least was accompanied by, general depression: 
La circulation se ralentit bien plutôt par les contrariétiés qu'elle éprouve que par le défaut d'encouragemens qu'elle reçoit. Ce sont les guerres, les embargos, les droits pénibles à acquitter, le danger ou la difficulté des communications, qui l'entravent. Elle est lente encore dans les momens de craintes et d'incertitudes; quand l'ordre public est menacé et que toute espèce d'entreprise est hasardeuse. Elle est lente quand on se croit exposé aux contributions arbitraires et que chacun s'efforce de cacher ses facultés. Elle est lente dans un tems d'agiotage où les variations subites occasionnées par le jeu sur les merchandises, fait espérer à quelques personnes un bénéfice fondé sur une simple variation dans les prix. Alors la marchandise attend à l'affût d'une hausse; l'argent à l'affût d'une baisse: des deux parts, capitaux oisifs, inutiles à la production.

Thus the 'impossibility' of general excess supply pertains only to freely operating systems under normal conditions, and in the long run, not to real-world conditions entailing arbitrary interventions and uncertainty.

\section{The evolution of Say's position: general excess supply and the problem of 'counter-commodities'}

There are no significant additions or alterations in the second edition of the Traité on the broad matter of savings-is-spending:

Il est bien essentiel, qu'on remarque, que de manière ou d'autre, soit qu'on dépense improductivement une épargne, soit qu'on la dépense productivement, elle est toujours dépensée et consommée, et ceci détruit une opinion bien fausse, quoique bien généralement répandue, c'est que l'épargne nuit à la consommation. Toute épargne, pourvu qu'elle soit replacée, ne diminue en rien la consommation, et, au contraire elle donne lieu à une consommation qui se reproduit et se renouvelle à perpétuité, tandis qu'une consommation improductive ne se répète point.

(Say 1814, 1: 98-9)

As for the main Law of Markets theme - 'que c'est la production qui ouvre des débouchés aux produits' - that reappears in a much expanded chapter 'Des Débouchés' with amplification in a companion chapter. Again allusion is made to the same secular experience as in 1803 - reference to the reign of Charles VI (145n.). Scarcity of money in that context constitutes no problem on the same Smithian grounds as before:

La marchandise intermédaire qui facilite tous les échanges (la monnaie) se remplace dans ces cas-là avec la plus grande facilité par des moyens connus des négocians, et bientôt la monnaie afflue, par la raison que toute espèce de marchandise se rend aux lieux où l'on en a besoin. 
Money acts simply as a medium of exchange: 'l'argent ne remplit qu'un office passager dans ce double échange; et les échanges terminés, il se trouve toujours qu'on a payé des produits avec des produits' (147).

The formulation is so far as in 1803. But now a potentially important paragraph is added to reinforce the notion of rapid expenditure of sales proceeds:

Il est bon de remarquer qu'un produit créé offre, dès cet instant, un débouché à d'autres produits pour tout le montant de sa valeur; car tout produit n'est créé que pour être consommé, soit reproductivement, soit improductivement, et même pour être consommé le plutôt possible, puisque toute valeur qui attend, fait perdre à celui qui en est actuellement le possesseur, l'intérêt de cette attente; le marchand a soin de ne pas avoir des merchandises qui doivent rester en magasin, et le consommateur a soin de ne pas en acheter très-long-temps avant le moment d'en faire usuage. Un produit est donc toujours, autant que chacun peut, destiné à la plus prompte consommation. Du moment qu'il existe, il cherche donc un autre produit avec lequel il puisse s'échanger. Je n'en excepte pas l'or et l'argent; car à peine le marchand a-t-il vendu, qu'il cherche l'emploi du produit de sa vente. On voit donc que le fait seul de la formation d'un produit, ouvre dès l'instant même, un débouché à d'autres produits.

Baumol finds in this paragraph a significant advance over 1803 in the rationale - avoidance of loss of interest - which assures that '[s]upply and demand are always equated by a rapid and powerful equilibrating mechanism', since neither James Mill nor Say 'offered an explicit exposition of Say's law' until 1814 when the latter 'describes explicitly the logic of Say's law as we interpret it nowadays' (Baumol 1977: 159, 147; see also Baumol 2003: 46, Forget 1999: 170; 2003: 56, 62). We have shown, however, the same rationale to be present already in 1803 (above, p. 193). In fact, the 1814 text uses precisely the same terms: 'le désir que chacun a, surtout les producteurs, de ne perdre que le moins possible l'intérêt des fonds engagés dans l'exercise de leur industrie' (Say 1814, 1: 164). This rationale is also supplemented, as before, by the motive for rapid disbursements reflecting fear of potential loss of purchasing power in periods of inflationary expectations (165). And Say also reiterates that - in the absence of 'les mauvaises administrations' - the secular process involving consumption and investment demand proceeds faultlessly:

Il s'agit bien moins de donner l'envie de consommer que d'en procurer les moyens; et nous avons vu que la production, qui donne les moyens de consommer, suffit pour que la consommation ait lieu, soit reproductivement soit improductivement, puisque le fruit de cette production serait perdu s'il n'était employé et que le retard même de son emploi est 
une perte. Aussi ce sont les mauvaises administrations qui excitent à consommer: les bonnes excitent à produire.

We turn to the opening declaration in the passage that has attracted so much attention, namely that 'un produit créé offre, dès cet instant, un débouché à d'autres produits pour tout le montant de sa valeur'. That Say did not intend to deny the possibility of excess supply by this strong formulation is clarified in what follows, where he explains that excess in some sectors is created by some impediment obliging reduced production of so-called counter-commodities which, by lowering incomes in those industries - Say implicitly assumes elastic demand schedules - reduces expenditures on other products, thereby generating excess supply:

Je me bornerai à faire remarquer ici qu'un défaut d'écoulement d'un produit, ou même d'un grand nombre de produits, n'est que le résultat d'un engorgement dans un ou plusieurs des canaux de l'industrie; qu'il se trouve alors dans ces canaux une plus grande quantité de ces produits que n'en réclament les besoins généraux, et que c'est toujours parce que d'autres canaux, loin d'être engorgés, sont au contraire dépourvus de plusieurs produits qui, en raison de leur rareté, sont aussi recherchés que les premiers le sont peu. C'est parce que la production des produits manquans a souffert, que les produits surabondans ne trouvent point de débit, et que leur valeur s'est altérée. En termes plus vulgaires, beaucoup de gens ont moins acheté, parce qu'ils ont moins gagné; et ils ont moins gagné, parce qu'ils ont trouvé des difficultés dans l'emploi de leurs moyens de production, ou bien parce que ces moyens leur ont manqué.

By the same token, the solution to such excess is the removal of those impediments allowing productive factors to flow towards industries in short supply ('les canaux vacans'), the renewed expansion of which - the purchasing power thereby generated - will absorb the excess supplies in question. It is not a matter of resources transferring between sectors but of new or renewed investments being made in industries hitherto in short supply:

Aussi l'on peut remarquer que les temps où certaines denrées ne se vendent pas bien, sont précisément ceux où d'autres denrées montent à des prix excessifs; et, comme ces prix élevés seraient des motifs pour en favoriser la production, il faut que des causes majeures ou des moyens violens, comme des désastres naturels ou politiques, l'avidité ou l'impéritie des gouvernemens, maintienne forcément cette pénurie d'un côté, qui cause un engorgement de l'autre. Cette cause de maladie politique vient-elle à cesser, les moyens de production se portent vers les canaux vacans, et le produit de ceux-ci absorbe le trop-plein des autres; 
l'équilibre se rétablit, et cesserait rarement d'exister, si les moyens de production étaient toujours laissés à leur entière liberté. ${ }^{3}$

Classification of this sort of problem is a little tricky. That some sector is in short supply implies that general excess is not the issue. On the other hand, the solution entails removal of the bottleneck and a consequential net expansion of activity, rather than reallocation.

Now it is true that this counter-commodity argument is also to be found in 1803 (above, p. 190), but so too - and in very explicit terms - is the argument for correction in terms simply of resource reallocation between sectors (above, p. 192). Say in 1814 omits the latter and argues entirely in terms of the former. I can think of no reason for this alteration, and find it difficult to believe that he had abandoned interindustry transfer as playing at least some part in the solution to excess supply. But even in that case it seems clear that he played it down in favour of net expansion of the industries hitherto in short supply with a resultant stimulus accorded depressed sectors. This is a change in weighting that must be recorded.

An instance provided of contemporary relevance suggests that Say had in mind an agricultural shortfall affecting industry, the latter characterized by excess supply, falling wages and profits and risky investment:

dans tout état où la production marche péniblement et ne remplace jamais la quantité des valeurs consommées, les demandes allant en déclinant, il y a toujours plus de marchandise offerte que de marchandise vendue; les profits, les salaires, diminuent, l'emploi des capitaux devient hasardeux.

Say refers also to 'cette prodigieuse difficulté qu'on éprouve, surtout quand la situation des affaires générales est peu prospère pour l'écoulement des produits de l'industrie, d'où il résulte qu'on en tire alors un parti peu avantageux' (148; emphasis added). Now that industrial output is used here as a generic term to include agriculture is unlikely, considering a further reference to French experience in 1813 which seems to refer intentionally to industry in the narrow sense of the term:

La France a pu se former une idée de cette situation pénible en 1813. L'industrie y était dans un tel état de souffrance, toute espèce d'entreprise industrielle y était tellement dangereuse, ou si peu lucrative, que les capitaux n'y trouvaient point d'emploi avec une sûrété tolérable; chaque fois qu'ils recontraient cette sûreté, ils se prêtaient moyennant un très-faible intérêt; et le bas intérêt des capitaux, qui est ordinairement une marque de prospérité, y était un signe de détresse.

(159n.; emphasis added)

Later editions confirm our reading, as we shall shortly see. 
Though Say raised the prospect of permanent stagnation and even decline 'si cet état dure, la dépopulation, le besoin et la barbarie prennent la place de l'abondance et du bonheur, auquel toute nation peut atteindre quand elle veut' (159) - it is industrial depression not secular stagnation or regression that was his immediate concern. And though he interpreted the depression formally as a result of a failure of 'counter-commodities', to designate poor harvests and their effect in reducing demand for industrial products under this rubric is hardly helpful; in any event, he accorded the industrial depression a life of its own, since he rehearses the 1803 argument involving excess demand for money to hold in the event of deflationary expectations (above, pp. 193-4), when the concern to avoid loss of interest characterizing quiescent times (I use J. S. Mill's term) gives way (164). All the characteristics of general excess at least in manufacturing emerge.

$$
* * *
$$

We move forward to later versions of the Traité. Here we find confirmation of our reading of the 1814 text as entailing an agricultural shortfall generating excess supply and depression in the industrial sector. Thus the 1817 edition adds a note to the proposition that 'les temps où certaines denrées ne se vendent pas bien, sont précisément ceux où d'autres denrées montent à des prix excessifs' (above, p. 196), specifying agricultural short supply in the period 1811-13 which damaged the market for other products:

Il est facile à tout lecteur d'appliquer ces observations générales aux pays et aux époques dont il a connaissance. Nous en avons eu un example bien frappant en France, dans les années 1811, 1812 et 1813, où l'on a vu marcher de front le prix exorbitant des denrées coloniales, du blé, et de plusieurs autres produits, avec l'avilissement de beaucoup de denrées qui ne trouvaient que des débouchés désavantageux.

(Say 1817, 1: 147n.; 1819a, 1: 154-5n.; 1826a, 1: 185n.)

And he proceeds to describe the characteristics of the 1813 depression with specific reference to the industrial sector. ${ }^{4}$ The 1819 version emphasizes further the causal feature at play by affirming that '[u]ne mauvaise récolte ... nuit à toutes les ventes' (1819a, 1: 153), and adds the comment under the entry 'DEBOUCHES' in the dictionary of terms or Épitome: 'quand les récoltes manquent, les produits des manufactures ne se vendent pas bien, parce qu'une partie du produit des manufactures est acheté avec le produit des récoltes' (1819a, 2: 464-5).

There is though one modification. The central passage in the chapter 'Des Débouchés' first introduced in 1814 (above, p. 195), no longer refers explicitly in 1817 and thereafter to avoidance of loss of interest to explain the supposed rapid disbursement of money receipts under normal conditions: 
Il est bon de remarquer qu'un produit créé [1826: terminé\} offre, dès cet instant, un débouché à d'autres produits pour tout le montant de sa valeur. En effet, lorsque le dernier producteur a terminé un produit, son plus grand désir est de le vendre, pour que la valeur de ce produit ne chôme pas entre ses mains. Mais il n'est pas moins empressé de se défaire de l'argent que lui procure sa vente, pour que la valeur de l'argent ne chôme pas non plus. Or, on ne peut se défaire de son argent qu'en demandant à acheter un produit quelconque. On voit donc que le fait seul de la formation d'un produit ouvre, dès l'instant même, un debouché à d'autres produits. 5

$(1817,1: 145 ; 1819 a, 1: 153 ; 1826 a, 1: 183)$

But it is not certain that we are witness here to a deliberate change in position since the companion chapter retains unchanged avoidance of loss of interest as rationale for speedy disbursement of proceeds under normal conditions $(1817,1: 161-2 ; 1819 a, 1: 169-71 ; 1826 a, 1: 201-3)$. The effects of uncertainty on spending decisions and the inflationary experience of the assignats episode - the panic flight from money - appear as in the earlier editions.

A revised entry under 'DÉBOUCHÉS' in the analytical dictionary of terms provides a helpful summary of several of the main principles - that money is a mere medium of exchange; that products are bought with products; that a newly produced 'value' opens up 'dès ce moment un débouché à une autre valeur produite'; and that a failure of sales and low prices in one industry is counterbalanced by shortages and high prices elsewhere:

DÉBOUCHÉs. Ce sont les moyens d'écoulement, les moyens d'échange, les moyens de vente pour un produit.

L'abondance de l'or et de l'argent monnayé n'est pas ce qui facilite les débouchés. La monnaie n'est qu'un intermédaire dans les échanges; celui qui la donne n'a pu se la procurer qu'en échange des fruits de sa production. Les produits ne sont donc en définitive achetés qu'avec des produits, et l'étendue des débouchés est proportionnée à l'étendue de la production.

Toute valeur nouvellement produite à moins qu'elle ne soit immédiatement détruite par la consommation, ouvre dès ce moment un débouché à une autre valeur produite; elle appelle en échange un autre produit. Ainsi, quand la vente d'un objet languit, c'est parce qu'il n'y a pas assez d'autres objets produits [1819: pour qu'on puisse l'acheter]; et . . l'avilissement dans le prix de certaines choses [1819: qui sont trop abondantes] est toujours accompagné d'un renchérissement dans certaines autres choses [1819: qui sont trop rares relativement aux premières].

(1817, 2: 440-1; 1819a, 2: 464)

The 1817 version summarizes simply: 'les époques où la vente de certaines merchandises ne va pas, sont des époques de cherté pour d'autres merchandises'. 
The 1819 version is more specific: 'quand les récoltes manquent, les produits des manufactures ne se vendent pas bien, parce qu'une partie du produit des manufactures est acheté avec le produit des récoltes'. In both versions there is attached a note to the effect that in a freely operating system there would be a flow of factors towards sectors in short supply opening up a market for the depressed sectors. As in 1814, this solution to excess does not involve transfer of resources from depressed to profitable industries, but a flow of capital to the latter creating the demand required to absorb excess supply in the former:

Les moyens de production se porteraient toujours vers la production des marchandises les plus chères, et par conséquent ouvriraient des débouchés aux marchandises avilies, si l'industrie était toujours libre dans ses mouvements. C'est la cause principale qui fait que les guerres, les mauvaises lois (telles que la prohibition des produits étrangers, les entraves intérieures, etc.), nuisent aux débouchés, le plus souvent sans que les parties intéressées s'en doutent.

$$
\text { (1817, 2: 441n.; 1819a, 2: 464-5n.) }
$$

The revised 1826 version of the entry 'DÉBOUCHÉs' distinctly reaffirms attribution of failures of counter-commodities to the effect of taxation in raising cost price rendering their production unprofitable and thus closing off markets for other products; and again refers to agricultural shortfalls with their depressing effect on the demand for manufactures:

Le défaut de production, et par suite de débouchés, vient quelquefois de ce que la production est rendue trop chère par des impôts excessifs ou une industrie imparfaite; quelquefois il vient d'une force majeure qu'il est impossible de surmonter. Quand les récoltes manquent, les produits des manufactures ne se vendent pas bien, parce qu'une partie du produit des manufactures est acheté avec le produit des récoltes.

(1826a, 3: 281-2)

The 1819 version of the central chapter 'Des Débouchés' introduces the objection that the various products in excess supply should, in principle, provide markets for each other on the principle that 'le fait seul de la formation d'un produit ouvre, dès l'instant même, un débouché à d'autres produits' (above, p. 199). The answer recognizes excess supply reflecting miscalculation, implying that correction would require a degree of resource reallocation, but nonetheless emphasizes failure of counter-commodities:

Cela étant ainsi, d'où vient, demandera-t-on, cette quantité de marchandises qui, à certaines époques, encombrent la circulation, sans pouvoir trouver d'acheteurs? pourquoi ces marchandises ne s'achètent-elles pas les unes les autres? 
Je répondrai que les marchandises qui ne se vendent pas, ou qui se vendent à perte, excèdent la somme des besoins qu'on a de ces marchandises, soit parce qu'on en a produit des quantités trop considérables, soit plutôt parce que d'autres productions ont souffert. Certains produits surabondent, parce que d'autres sont venus à manquer. ${ }^{6}$

(1819a, 1: 154; 1826a, 1: 184; emphasis added)

This situation is attributed to 'des causes majeures ou des moyens violens'. And the solution hinged on correction of the impediment in question:

Cette cause de maladie politique vient-elle à cesser, les moyens de production se portent vers les routes où la production est demeurée en arrière; en avançant dans ces voies-là, elle favorise l'avancement de la production dans toutes les autres. Un genre de production devancerait rarement les autres, et ses produits seraient rarement avilis, si tous étaient toujours laissés à leur entière liberté.

(1819a, 1: 155, 1826a, 1: 185)

Thus the substance remains as in 1814 and 1817. Correction involves a net expansion of goods hitherto in short supply generating renewed markets for those hitherto depressed, though transfers of resources between sectors are not explicitly precluded.

A footnote added in 1819 treats the hoarding phenomenon as irrelevant in the long run, implying that it might be of short-run significance:

Lors même que ce serait pour enfouir la somme, le but ultérieur est toujours d'acheter quelque chose avec la somme. Si ce n'est l'enfouisseur qui achète, c'est son héritier, c'est celui aux mains de qui la somme tombe par quelque accident que se soit; car de la monnaie, en tant que monnaie, ne peut servir à aucun autre usage.

(1819a, 1: 149-50n.; 1826a, 1: 177n.)

This sort of formulation seems to be in the nature of an escape clause to retain the Law of Markets in its unqualified sense; strictly defined, it did hold good but only in a secular framework. This is confirmed by the reproduction, in the companion chapter on 'circulation', of the original 1803 reference (cited above, p. 194) to excess demand for money to hold specifically during periods of deflationary expectations (1819a, 1: 169-70; 1826a, 1: 201-2).

Having said this, we must face the frustrating fact that the entry 'PRODUCTION' in the 1819 Épitome seems to propose a version of the Law of Markets applicable also to the short run, denying the possibility of excess supply in the aggregate and allowing only for resource misallocation:

Quelques auteurs qui n'ont pas assez étudié la matière, ont soutenu l'opinion que dans une société politique il pouvait y avoir surabondance 
de production: c'est une erreur. Il ne peut jamais y avoir surabondance que quand la valeur des choses produites n'égale pas leurs frais de production; mais les frais de production (c'est-à-dire la valeur des services productifs) ne peuvent être trop élevés pour produire ces choses, que parce que les mêmes services productifs sont plus demandés pour en produire d'autres; ce qui indique dans celles-ci une rareté relative. Une surabondance de produits n'est donc qu'une mauvaise distribution, un mauvais emploi, des moyens de production.

This sort of summary formulation, taken seriously, sets at naught all the allowances for short-run general excess supply even of the qualified sort created by a deficiency of counter-commodities. One can only suppose that Say was carried away by enthusiasm for the doctrine of services which he may have imagined was under threat. Be that as it may, the proposition is removed from the 1826 entry (1826a, 3: 308-11).

It is appropriate to point here to one of Say's Notes on Ricardo's Principles printed with the Constancio translation of 1819 (see Appendix I), touching on excess demand for money to hold. The comment is attached to an objection raised by Ricardo against Say's argument (1814, 2: 301-2) that the effect of a reduction in fish-market dues is to generate a net increase in national income, that is the objection that an expansion of any one sector necessarily entails a contraction elsewhere (Ricardo 1951-73, 1: 238). Say's Note, while accepting the validity of Ricardo's case assuming strict fullcapacity usage, points to instances of unused money reserves - 'une foule de petites sommes mises en réserve'. Here Say is pointing, apparently for the first time, to money held as reserve for precautionary motives:

Rigoureusement parlant, M. Ricardo a, dans ce cas-ci, raison contre moi. Certes, si tous les capitaux étaient aussi bien employés qu'ils peuvent l'être, on ne pourrait donner de l'accroissement à une industrie sans retirer à une autre une partie de ses instrumens; mais dans la pratique rien ne se fait avec cette rigueur. Une industrie qui s'élève, et surtout lorsqu'elle se compose de petites entreprises, comme le commerce de la marée, s'élève au moyen d'une foule de petites sommes mises en réserve, et qui n'avaient souvent aucun utile emploi. On les met au jour, on ne craint pas de les hasarder lorsqu'une occasion favorable se présente. Plusieurs industries comme celle-ci exigent peu de capitaux. La marée ne pouvant se conserver plus de trois ou quartre jours, il faut qu'elle soit revendue presque aussitôt qu'achetée; elle n'admet pas de longues avances. 
The scope provided net output expansion by absorption of such reserves calls to mind J. S. Mill's later real and money funds available at various stages of production to satisfy expected sales in the one case and make necessary purchases in the other (Mill 1963-91 [1844], 4: 278-9). But whereas Mill's case was quite general Say seems to have been concerned with a range of special cases. It is, however, possible that by the late 1820s Say came to weigh the case more heavily, as we shall suggest in the next section.

\section{The interpretation of contemporary depression}

We have briefly considered above Say's interpretation of the French depression 1811-13 (see p. 198). We turn now to the Lettres à M. Malthus (1820), designed specifically to account for the contemporary phenomena of excess capacity and 'general glut':

What is the cause of the general glut of all the markets in the world, to which merchandise is incessantly carried to be sold at a loss? What is the reason that in the interior of every state, notwithstanding a desire of action adapted to all the developments of industry, there exists universally a difficulty of finding lucrative employment?

(Say 1821 [1820]: 2)

At the close of his Lettres, Say refers to 'that great malady which at present afflicts mankind, and which prevents their living upon their productions' (75). The analytical background provides an excellent résumé of the Smithian underpinnings of Say's position.

Say first laid out the notion that it is the income generated by production which provides the wherewithal to make purchases, while money serves only as medium of exchange (2). Similarly: 'the only true consumers are those who on their side produce, because they alone can buy the produce of others; . . . unproductive consumers can buy nothing, unless by means of the value created by those who produce' (4). But despite his indebtedness to Smith, Say considerably sharpened the conception of circular flow in an enterprise economy, an extended outline of which is given in order to discover 'whether we have not the means of consuming what we have the means of producing', in answer to Malthus's objection that James Mill and Ricardo as well as Say himself had 'considered commodities as if they were so many mathematical figures, or arithmetical characters, the relations of which were to be compared, instead of articles of consumption, which must of course be referred to the numbers and wants of the consumers' (10).

Secondly, the savings-is-spending theorem is formulated in the following passage, where one notes the recognition, but downplaying, of misers' hoards: 
[What] the capitalists would have saved would nevertheless have been equally expended. In expending it unproductively, the expenditure has not been increased in amount. As to riches accumulated, without being reproductively consumed, such as the sums amassed in the miser's coffers, neither Smith nor I, nor any one, undertakes their defence; but they cause very little alarm; first, because they are always very inconsiderable, compared with the productive capital of a nation; and secondly, because their consumption is only suspended.

Say goes on to complain that Malthus assumed 'a production saved' to be 'abstracted from every species of consumption' although in the writings of Say himself, as with Smith or Ricardo and - Say adds 'even in your own' 'a production saved is so much subtracted from unproductive consumption to be added to capital, that is to say, to the value that is consumed reproductively' (39). Again: 'accumulation is not non-consumption; it is the substitution of reproductive consumption for that which is unproductive' (39n.). ${ }^{7}$ In the Traité the same objection is addressed at Lauderdale for maintaining that private accumulation damages national wealth by reducing the consumption required to stimulate industry:

Son erreur vient de ce qu'il s'imagine faussement, avec beaucoup d'autres, qu'un capital accumulé est soustrait à la consommation; tandis qu'au contraire il est consommé, mais reproductivement, et qu'il procure ainsi le moyen de recommencer à perpétuité des achats qui n'auraient eu lieu qu'une fois, s'il eût été consommé improductivement.

$$
\begin{array}{r}
\text { (1814, 2: 39n.; 1817, 2: 46n.; 1819a, 2: } \\
\text { 47-8n.; 1826a, 2: 192n.) }
\end{array}
$$

It should be remarked that subscription to the 'savings-is-spending' theorem does not necessarily imply an 'advances' model as is sometimes suggested (Corry 1962: 21; Eagly 1974: 91). Say did not actually eschew the advances notion (above, p. 175), but as far as concerns the Law of Markets, the theorem is used within the context of a 'circular-flow' model in order to show that the flow is not 'broken' at any point when 'savings' are made. Interest and rent - on a par with wages - are simply the incomes paid by the entrepreneur for the services of capital goods and land, the suppliers of which devote their earnings to the purchase of the commodities produced whether for consumption or investment (Say 1821 [1820]: 18-19).

We take this occasion to note a curiosum pointed out by Baumol (1997: 228-9): the fact that from 1814 onwards the 'Discours préliminaire' of the Traité carries a flat denial that the saving-is-spending theorem - indeed the productive-unproductive consumption classification - is to be found in the Wealth of Nations: 
Enfin, quoique le phénomène de la consommation des richesses ne soit que la contre-partie de celui de la production, et que la doctrine de Smith conduise à l'envisager sous son vrai point de vue, Smith ne le développe point; ce qui l'empêche d'établir plusieurs vérités importantes. C'est ainsi que, ne caractérisant pas les deux sortes de consommations, l'improductive et la reproductive, il ne prouve point d'une manière satisfesante que la consommation des valeurs épargnées [1817, 1819, 1826: et accumulées pour former des capitaux], est aussi réelle que la consommation des valeurs qu'on dissipe.

(Say 1814, 1: lvi; 1817, 1: liii-liv; 1819a, 1: lvii; 1826a, 1: lxxi)

This assertion is incomprehensible and conflicts with Say's recognition of Smith as precursor in the Lettres à M. Malthus.

One principal 'deduction' drawn by Say in the Lettres from his conceptualization of the economic process is the central notion - as in the Traite - that 'productions can only be purchased with productions ... it is production which opens a market to production' (Say 1821 [1820]: 24); that 'we purchase commodities with productive services, and ... the more productive services we carry to market, the more we can buy in return' (16); or, at a more general level, that 'all the producers possess collectively the means of acquiring the whole of the productions' (27).Now these formulations strictly speaking imply only the potential to purchase. Say also cites a passage from his Traité asserting more strongly that the potential is fulfilled:

From these premises I had drawn a conclusion which appeared to me evident, but which seems to have startled you. I had said 'As each of us can only purchase the productions of others with his own productions as the value we can buy is equal to the value we can produce, the more men can produce, the more they will purchase.'

(3; emphasis added)

As for empirical evidence, Say refers loosely to 'experience' which, along with 'reasoning',

demonstrates that a production ... is only rejected when people have not the means of paying for it. These means of purchasing are precisely those which establish the demand for a production, and give it a price. Not to want an useful thing is not to be able to pay for it. And what occasions this inability to pay for it? The being deprived of that which constitutes wealth: the being deprived of industry, land, or capital.

More seriously, the conclusion that 'production opens a market to produce' is supported, as in the Traité, by the experience of secular progress, the huge 
increase in the volume of internal British sales since Queen Elizabeth's time accounted for in terms of corresponding output expansion (4f.).

We also find, again as in the Traité, the further so-called 'deduction' that 'if certain goods remain unsold it is because other goods are not produced' (3) - the counter-commodity problem. Say in fact opposes Malthus on just these grounds:

I have advanced that whenever there is a glut, a superabundance, of several sorts of merchandise, it is because other articles are not produced in sufficient quantities to be exchanged for the former; and if those who produce the latter could provide more of them, or of other goods, the former would then find the vent which they required: in short, that the superabundance of goods of one description arises from the deficiency of goods of another description. You on the contrary, assert that there may be a superabundance of goods of all sorts at once. ... M. Sismondi had already opposed my doctrine.

And as in the Traité, the source of such excess is traced to interferences of various sorts:

We have hitherto founded our discussions upon the supposition of an indefinite liberty, allowing a nation to carry to the utmost extent production of every description; and it appears to me that I have proved that if this hypothesis could be realized, a nation so circumstanced would be able to purchase all that it could produce.

In response to Sismondi's and Malthus's objections to his conception of the Law of Markets in the light of the fact of excess capacity and supply, Say observed: 'To buy the superabundant produce, it would be requisite to create other produce: but if the producers were placed in too disadvantageous a situation', the returns from any such production would not cover expenses (48). Or in his favoured terminology, "the utility of productions is no longer worth the productive services, at the rate at which we are compelled to pay for them' (51).

$$
\text { * * * }
$$

Conspicuously lacking are actual illustrations of counter-commodities supposedly in short supply. In fact, the empirical references that Say does provide relate to general excess, and not the partial excess characterizing the counter-commodity case, just as one would expect in a monograph on 'the stagnation of commerce' and 'the general glut in all the markets of the world'. The formulation of 1820 illustrates well the sort of difficulty Say 
created for his readers and perhaps for himself. On the one hand, he insisted against Malthus and Sismondi that there could be no 'superabundance of goods of all sorts at once', relying on the old counter-commodity argument that excess supply of certain goods implies a shortfall in others; on the other hand, within the course of a page or two, he allowed general excess - indeed this is the contemporary problem he set out to explain - and alluded to net hoarding if not as cause then as consequence. Here is an invitation to misunderstanding.

We turn now to the central argument. General excess is reflected in a net demand for money to bold, namely 'capitals ... quietly sleeping in the coffers of their proprietors' and 'many savings [that] are not invested', Say taking issue with Ricardo for allegedly neglecting such a phenomenon despite the presence of 'taxes and other charges':

Mr. Ricardo insists that, notwithstanding taxes and other charges, there is always as much industry as capital employed; and that all capital saved is always employed, because the interest is not suffered to be lost. On the contrary, many savings are not invested, when it is difficult to find employment for them, and many which are employed are dissipated in ill-calculated undertakings.

(Say 1821 [1820]: 49n.)

And there was convincing evidence:

Besides, Mr. Ricardo is completely refuted, not only by what happened to us in 1813, when the errors of Government ruined all commerce, and when the interest of money fell very low, for want of good opportunities of employing it; but by our present circumstances, when capitals are quietly sleeping in the coffers of their proprietors. The bank of France alone possesses 223 millions of specie (about nine millions of pounds sterling) in its chests, which is more than double the amount of its notes in circulation, and six times what prudence would consider necessary to reserve for the ordinary course of its payments.

(49-50n.)

Say's perspective implies that costs are increased by taxation without compensatory increase in government expenditure, to which notion Ricardo strongly objected (above, p. 182). Malthus, on the other hand, writing to Ricardo on 25 September 1820, expressed his delight with Say's recognition of general unemployment, excess capacity and low return on capital, which Ricardo was unable to account for; and he added to Say's empirical references:

[Say] fully concedes all that I contend for. He says 'qu'il y a beaucoup d'épargnes qui ne se placent pas lorsque les emplois sont difficiles, ou 
qui étant placées se dissipent dans une production mal calculé', and this he illustrates by the present state of France. The present state of things indeed in England, America, Holland and Hamburgh still more than in France does appear in the most marked manner to contradict both his, and your theory. The fall in the interest of money and the difficulty of finding employment for capital are universally acknowledged, and this fact, none of your friends have ever accounted for in any tolerably satisfactory manner.

(Malthus, in Ricardo 1951-73, 8: 260)

Malthus may have read Say as making a case for excess demand for money as 'cause' of general excess supply of commodities. But Say conceivably intended only its accompaniment, considering the emphasis accorded 'taxes and other charges' as impeding production by raising costs without compensatory governmental demand. In further elaboration of the character of the contemporary general depression, the failure of counter-commodities comes back into the picture again, pointing not to a monetary origin but to the 'excessive charges' imposed by taxation:

Returning to the painful situation in which all kinds of industry is at present placed in Europe, I might add to the discouragement resulting from the excessive increase of the charges of production, the disorders which such charges occasion in the production, distribution, and consumption of the values produced; disorders which frequently bring into the market a supply superior to the demand, and at the same time drive out of it much which might have been sold, and the prices of which would have been employed in the purchase of the former. . . . Hence arise disorders in the progress of production and consumption, still more grievous than those which originate in the prohibitions of the revenue or the vicissitudes of the seasons. Hence we see inconsiderate productions - hence recourse is had to ruinous means - hence commercial establishments are overthrown.

(Say 1821 [1820]: 58-9; emphasis added)

To this Say adds ignorance and error which, he opines, were likely to pose less of a problem in the future:

This superabundance ... is also occasioned in part by the ignorance of producers or traders on the nature and extent of the demand in the places to which goods are consigned. Of late years there have been many speculations hazarded, because there have been many new relations between different nations. Data were everywhere wanting to serve as the foundation of good calculations; but does it follow that because many affairs have been unprofitable, that others with better information 
may not succeed? I venture to predict that as new relations shall grow old, and reciprocal wants be more justly appreciated, the markets will cease to be glutted, and permanent connexions of mutual profit will be established.

*** $*$

We come now to a paper of 1826, specifically devoted to the British 'commercial crisis', which points distinctly to a monetary explanation and says nothing of counter-commodities. Here Say defends economic theory against Sismondi's objections - in terms of 'Ricardian' principles no less: 'la dernière crise commerciale . . est expliquée par les principes de Ricardo sur les monnaies' (Say 1826c: 42-3). The argument, which takes account of British monetary institutions, focuses on initially excessive bank credit encouraging speculative expansions of activity followed by inevitable credit contraction generating bankruptcies and unemployment: 'Les entreprises commencées ont été arrêtées; les marchandises se vendant fort au-dessous de leur prix coûtant, les manufacturiers qui avaient travaillé avec le plus de prudence n'ont pu continuer leur fabrication; de là cette population d'ouvriers criant famine' (44).

The Cours complet contains a striking reference to the characteristic instability of manufacturing activity in consequence of fluctuations in aggregate demand, and here the impact of taxes and the counter-commodity case play no part:

Il y a dans tous les pays où l'industrie manufacturière est très-developpée, des moments où l'ouvrage ne va pas, et où la classe ouvrière toute entière est en souffrance. Ce malheur [tient] . . . à la nature des produits manufacturés qui sont en général exposés à de grandes vicissitudes dans la demande qu'on en fait.

(Say 1843 [1828-9]: 90) ${ }^{8}$

Beyond this, we find elsewhere in the Cours complet an impressive account of general depression and unemployment in Britain in 1824 - in line with the 1826 paper - the origins of which are traced back to inflationary bank issues leading to gold outflows, which obliged the Bank of England and subsequently the country banks to contract their loans (223). As a result,

le commerce s'est trouvé privé tout à coup des avances sur lesquelles il avait compté, soit pour former des entreprises nouvelles, soit pour donner plus d'extension aux anciennes. A mesure que l'échéance arrivait des engagements que les négociants avaient escomptés, ils ont dû les acquitter; et ne trouvant plus d'avances chez les banquiers, chacun a été forcé d'user de toutes les ressources dont il pouvait disposer; on a vendu 
des marchandises pour la moitié de ce qu'elles avaient coûté; on n’a trouvé à vendre le fonds des entreprises pour aucun prix; toute espèce de marchandises ayant baissé au-dessous de leurs frais de production, une multitude d'ouvriers sont restés sans ouvrage; beaucoup de faillites se sont déclarées parmi les négociants et parmi les banquiers, qui ayant mis dans la circulation des billets au porteur pour une somme plus forte que celle dont pouvait répondre leur fortune personnelle, n'avaient plus pour gage de leurs émissions que des engagements de particuliers dont plusieurs étaient faillis.

Apart from this Ricardo-based account of depression characterized by excess demand for money due initially to credit contraction, Say also opined - as in the 1819 and 1826 editions of the Traité (above, p. 201) - that full expenditure of money funds acquired by sale of commodities might require more than one generation; hoarding over a shorter period is not precluded:

Quand même nous cacherions la somme dans la terre, ce serait toujours afin de nous en servir plus tard pour acheter quelque chose. Que si nous mourions avant de l'avoir déterrée, ce seraient alors nos héritiers . . . qui l'emploieraient de cette manière; son emploi ne serait que différé.

In this light we can better appreciate Say's recognition of the holding of money reserves that may be called upon in certain circumstances to finance net expansion. For, as in his 1819 Notes (above, p. 202), Say argues in the Cours complet on methodological grounds against the Ricardians and what later came to be called its 'Treasury View' implications:

Dans l'école qui fonde les déductions de l'économie politique sur des abstractions, on insiste trop sur ce principe que l'industrie est bornée par l'étendue des capitaux, et n'est bornée que par eux. . . [U]n pays renferme une immense quantité de petits capitaux inoccupés que les circonstances mettent en lumière.

Also as in 1819, Say responds on related grounds to Ricardo's objections to the Turgot fish-duties analysis:

J'avais dit, dans mon Traité d'Économie politique, que Turgot, en diminuant de moitié les droits de la marée qui venait à Paris, en doubla la production. Ricardo croit que la production ne saurait être augmentée quand la somme des capitaux ne l'est pas. Il ne voit, en conséquence, aucun avantage dans la bienfaisante mesure de Turgot: les capitaux que l'on donna de plus, dit-il, à la production de la marée, furent retirés 
d'une autre production. Mais il n'est pas possible d'admettre que la production soit toujours proportionnée à la somme des capitaux. Nous avons vu plus haut [345] qu'une foule de petites portions de capitaux peuvent être employées qui ne le sont pas; et que beaucoup de capitaux productifs peuvent être réduits à l'inaction.

Now these illustrations point to the phenomenon of idle funds in a range of minor industries. This is far from the case in the further illustrations drawn from Napoleonic and post-war France and from some of the wartime coalition partners, especially Prussia, pointing to increased military expenditures and the payment of post-war reparations without contraction in other sectors. These illustrations, though supposed to 'prove' the holding of financial reserves, in fact relate rather to the imprecision of the capital constraint in the sense that new capital can be raised by means of increased 'activity' in emergencies:

Je n'en veux pour preuves que les contributions accidentelles auxquelles un pays peut être exposé sans altérer sensiblement sa production. Il semble qu'un peuple rachète, par l'activité de son travail, les sommes capitales qui viennent à lui manquer par accident.

As for the specifics:

Dans les coalitions contre Bonaparte, les nations liguées semblaient n'avoir point d'argent; elles fournissaient avec une apparente difficulté les contributions imposées par leurs princes pour soutenir ces guerres, et les princes se trouvaient contraints de se mettre à la solde de l'Angleterre. Bonaparte fit l'invasion de la Prusse en 1806; il la garda jusqu'en 1812, et ses agents surent en tirer des sommes considérables. La Prusse fut-elle ruinée? Non, car en 1814 et 1815, lorsqu'il fallut marcher contre celui qui l'avait opprimée, elle trouva le moyen d'équiper à ses frais une nouvelle armée plus considérable qu'aucune de celles qu'elle eût jamais mises sur pied. Ses capitaux industriels furentils épuisés par tant d'efforts? Probablement que non; car son industrie n'a jamais plus prospéré que depuis cette époque.

La France fut à son tour mise à contribution en 1815 par les nations coalisées; elle leur paya trois milliards: et, avant qu'aucune accumulation importante eût eu le temps d'être faite de nouveau, jamais plus de capitaux ne furent consacrés à l'industrie que depuis ce moment. Ils ont été tellement abondants, que l'on a vu à la banque de France, pendant plusieurs années, deux cents millions de dépôts en espèces, lorsque cette banque n'avait que cent millions de billets en emission. 
All this proved Say's point against the Ricardians:

Ne sont-ce pas là des preuves que, quoiqu'il soit vrai en principe, que l'industrie repose sur les capitaux et se proportionne à leur étendue, cette donnée est trop vague pour que la doctrine métaphysique puisse en faire le fondement de calculs rigoureux?

\section{'Limits to production': the Law of Markets recanted?}

It will be recalled that Say in the Notes of 1819, under pressure from Ricardo, abandoned the Smithian doctrine of 'competition of capitals' as conflicting with the Law of Markets: ' $j$ 'ai eu tort de dire que les capitaux peuvent être plus ou moins abondans par rapport à l'étendue des emplois, ayant prouvé ailleurs que les emplois se multiplient en proportion de l'abondance des capitaux' (see above, pp. 64-5). Here then Say declares his adherence to the Law of Markets as a secular proposition. Now rather tentatively he adds that general stagnation affecting all or nearly all products might result from increase in cost prices, going beyond the standard counter-commodity case where only some products are in short supply:

Les seuls cas où l'observation que j'ai faite après Smith, pourrait être réelle, seraient ceux où la production est rendue si désavantageuse, soit en raison des impôts, ou par toute autre cause, qu'aucun produit ne vaut les sacrifices qu'il faudrait faire pour l'obtenir. Il y a bien certainement des produits qui ne se font pas, par la raison que leur prix-courant est inférieur aux frais de leur production. Ne peut-on pas supposer ce cas pour un si grand nombre de produits, que le nombre des emplois de capitaux et de facultés industrielles en soient considérablement réduits?

(Say 1819b 2: 107-8)

It is not clear how seriously to take this suggestion which seems to be more appropriate for secular stagnation and unrelated to market constraints.

The same problem will be found in the late 1820s. Thus Say's letter to Malthus of 24 February 1827 treats various constraints on secular expansion as 'quelques restrictions' faced by the doctrine of markets, the detailed analysis of which is given in the late Traité and in the Cours complet (see above, p. 122). We now note that elsewhere in the Cours complet itself will be found a passage that might be read as questioning the Law of Markets:

L'industrie, ainsi que nous l'avons remarqué en traitant de la production, est susceptible de s'étendre, de s'accroître en proportion des capitaux dont elle peut disposer; mais n'y a-t-il borne à cette extension? Les particuliers riches ne peuvent-ils pas amasser des capitaux tellement considérables, que les capitaux se multiplient au point d'excéder tous les besoins de l'industrie?

(Say 1843 [1828-9]: 351) 
In his response he takes the 'economistes abstraits' to task for their strict Law of Markets logic: 'Les économistes abstraits, sur le fondement que les produits peuvent se multiplier indéfiniment et par la raison qu'ils s'achètent les uns par les autres, disent que l'industrie n'est bornée que par l'étendue des capitaux.' But he himself provides no serious response to his own questions: 'Dans l'économie pratique les résultats reposent sur des données tellement compliquées, qu'ils ne sont pas susceptibles d'une solution si absolue.' More to the point, the technical argument relating to constraints on activity - as we have shown in Chapter 3 - in no way relate to the Law of Markets. ${ }^{9}$ Say did himself no service by expressing himself sometimes as if it did.

A further letter by Say to Malthus dated July 1827, the subject of considerable debate, requires mention. Say here apparently defends the Law of Markets on terminological grounds suggesting perhaps an abandonment of the Law in substance:

Notre discussion sur les débouchés commence à n'être plus qu'une dispute de mots. Vous voulez que j'accorde le nom de produits à des marchandises qui peuvent satisfaire un certain nombre de besoins et qui ont une certaine valeur, quoique cette valeur soit insuffisante pour rembourser la totalité de leurs frais de production. Mais le fond de ma doctrine sur la production établit clairement qu'il n'y a de production complète qu'autant que tous les services nécessaires pour cette oeuvre sont payés par la valeur du produit. Lorsqu'on dépense six francs en travaux et en argent, et qu'on ne produit qu'une valeur de cinq francs, il est évident qu'il n'y a réellement eu de produit qu'une utilité valant cinq francs; si elle a coûté d'avantage à produire, il y a eu un déficit d'utilité et de valeur, et c'est à ce déficit que je refuse le nom de produit. Je crois donc être autorisé à dire que tout ce qui est véritablement produit trouve à se placer; que tout ce qui ne se place pas a été une dépense faite inconsidérément sans rien produire; et ma doctrine des débouchés demeure entière.

(1843: 649)

This defence of the Law of Markets has been understood as warding off challenge by a terminological trick whereby if a product is created but remains unsold, no production can be said to have occurred, so that the Law remains intact (Thweatt 1979: 92); similarly, Baumol writes of it as 'a curious tautological version of Say's Law' (Baumol 1977: 159). At one time I defended Say, reading this specific letter as referring to the secular constraint imposed by a desire for leisure rather than goods (Hollander 1979: 94-5n.). I am now less sure considering the objection to that reading by Forget (1999: 172-3; 2003: 59). Moreover, we find a similar tautological defence in the Épitome to the 1826 Traité under 'PRODUCTION, PRODUIRE':

Pour qu'il y ait production de valeur, il faut que la valeur des produits créés égale tout au moins la valeur des services au moyen desquels on les a 


\section{The Law of Markets}

obtenus. La valeur des produits est le salaire des services rendus, et ce salaire n'est payé que lorsque la valeur produite vaut les frais de production. Si un homme, par son travail de trois jours, ne pouvait créer que sa subsistance de deux jours, il ne rentrerait pas dans ses avances, et ne pourrait pas continuer sur ce pied. . .

Ce principe résout la dispute de ceux qui prétendent qu'on peut trop produire, et de ceux qui soutiennent qu'on ne peut pas trop produire: on peut trop produire des choses qui ne méritent pas le nom de produits; et l'on ne peut pas trop produire des choses qui méritent le nom de produits, c'est-à-dire qui ont une valeur égale à leurs frais de production; car cette valeur même est une preuve qu'ils sont assez demandés pour devoir être consommés.

(Say 1826a, 3: 309-10)

This sort of unsatisfactory word-minded defence is thus conspicuous enough. Yet we must not lose sight of Say's substantive case relating to those constraints on activity of a secular nature - technological and factorsupply constraints - adumbrated in the 1826 Traité (and referred to in the letter to Malthus of 24 February 1827) and in the Cours complet. That case - in no way a weakening of the Law of Markets - remains untouched and fully in line with canonical classicism. Only with respect to taxation and its impact on secular expansion was there conflict, a matter considered in Chapter 4.

\section{The Law of Markets and Say's entrepreneur}

Forget has argued that 'Say's use of the law of markets was significantly different from the use made of it by others', considering the role accorded the entrepreneur:

He emphasised the mediating role of the entrepreneur. Indeed, the law of markets, according to Say, seems less an automatic equilibration mechanism, than an opportunity to celebrate the singular virtues of the all too rare individual with entrepreneurial talent. His analysis is not abstract, but embedded in an institutionally and historically constructed economic environment. He attempts to make the speculation concrete by emphasising the role that the entrepreneur plays in the story of adjustment, and focussing on the practical difficulty of creating markets in an uncertain world. Indeed, it is Say's characteristic focus on social and political stability as an over-riding goal of social analysis that links institutional and analytical thought in Say's economics. This is what distinguishes Say's own use of the law of markets from that of Ricardo and Malthus.

(Forget 2003: 62-3; emphasis added) 
Again, Say viewed the entrepreneur 'as the active force driving the adjustment mechanism assumed by the law of markets', which therefore turns out to be 'a whole lot more contingent and a little less spontaneous' (2003: 61; also 1999: 174-5).

What then of the role accorded the entrepreneur in the active creation of new sales opportunities? The tasks required of the entrepreneur do indeed include marketing as we have seen (above, p. 110). But that general exposition, excellent though it is, did not touch specifically on the present issue. Potentially more relevant is a passage cited by Forget from the Lettres à M. Malthus which emphasizes the temporary nature of the contemporary problem of general excess created by inadequate data relating to new international markets, and goes on 'to predict that as new relations shall grow old, and reciprocal wants be more justly appreciated, the markets will cease to be glutted, and permanent connexions of mutual profit will be established' (see for this passage above, p. 209). This leads Forget to the rather weak conclusion: 'The adjustment mechanism, then, while it may occur quickly, does not occur independently of the will and the decisions of the entrepreneur' (2003: 61; emphasis added). This last contention is uncontroversial; whereas what Say seems to be emphasizing is precisely the likelihood that 'the adjustment mechanism . . . may occur quickly', indeed is increasingly likely to do so. This is surely to play down the entrepreneurial function in the Law of Markets context. The same conclusion seems to me to emerge from a further comment regarding the entrepreneur - Say is writing in opposition to Sismondi - whereby misallocations are speedily corrected, the entrepreneur not generating those needs but rather 'conforming to the needs of the country':

Ce que M. de Sismondi redoute par-dessus tout, c'est l'encombrement des produits qui fait fermer les manufactures, interrompt le commerce et laisse les ouvriers sans emploi; mais cet encombrement, quand il a lieu, est l'effet des mauvais calculs des entrepreneurs, c'est-à-dire, d'une industrie trop peu éclairée, trop peu avancée. Si les conducteurs d'une entreprise d'agriculture, de manufacture, ou de commerce, savaient créer des produits qui pussent convenir à leurs consommateurs, s'ils savaient les établir à un prix qui en facilitât la consommation, si les consommateurs étaient assez industrieux pour offrir de leur côté des objets d'échange, cet encombrement cesserait, et se résoudrait en moyens de prospérité.

L'encombrement ne peut jamais être qu'accidentel; car il est le fait des entrepreneurs: en tout genre d'industrie, c'est l'entrepreneur et non l'ouvrier qui décide du produit qu'il faut faire, et de la quantité qu'il convient d'en faire. Or, l'intérêt de l'entrepreneur est, à chaque époque et dans chaque situation, de se conformer aux besoins du pays; autrement, la valeur vénale du produit baisserait au-dessous de ses frais de production, et l'entrepreneur perdrait. Son intérêt garantit donc qu'en chaque 
produit, les quantités créées ne peuvent, d'une manière permanente et suivie, excéder les besoins.

(Say 1848 [1824]: 257-8; emphasis added)

Say goes on to agree with Sismondi, that ' $[c]$ e sont . . . les besoins qu'il faut faire naitre', but his solution in this regard does not entail the entrepreneur, but rather the quasi-automatic outcome of rising affluence and 'civilization': 'l'aisance que procure une industrie plus active et une production moins chère, et les besoins qui naissent d'une aisance plus grande et des goûts plus civilisés qui en sont la suite' (258).

The creation of wants is, in fact, more relevant to the 'limits-to-production' issue including the desire for leisure rather than goods, and we know from that discussion that Say saw limits of this order (above, pp. 124-5). As for Ricardo, he regarded this sort of problem as pertinent to 'underdeveloped' economies, not contemporary Britain:

It is not necessary that in such a country as England new tastes and new wants should be generated - the old tastes are sufficient for the purpose. Tastes and wants exist already in a sufficient degree, give but the means of satisfying them and demand follow.

(Ricardo 1951-73, 4: 344)

As for Say, the passage in question refers to opposing forces at play as society becomes progressively more 'civilized'; but the above-cited response to Sismondi confirms the more optimistic perspective.

Forget herself emphasizes the entrepreneurial role in relation to regional and national development: 'If a country lacks an industrial climate and does not foster the development of entrepreneurs, that nation will lag behind its neighbours in industrial development, and sometimes languish with economic opportunities not seized' (2003: 61; also 1999: 175). Here she is apparently paraphrasing one or both of the following passages in the Cours complet, which in fact allude to specific entrepreneurial qualities unrelated to the creation of markets:

C'est un des faits les mieux constatés par l'expérience, que tous les peuples dont les institutions dépravent le jugement, ont une industrie languissante. En Irlande, la partie nord-est, qui est la partie de l'île la moins favorisée par la nature, mais dont les habitants sont en majeure partie protestants, est industrieuse et riche. La partie sud-ouest, dont les habitants se laissent conduire par des prêtres et se livrent à des pratiques très-superstitieuses, a peu d'industrie, et végète dans la plus affreuse misère. On a fait depuis longtemps la même observation sur l'Espagne.

(Say 1843 [1828-9]: 141)

C'est cette audace judicieuse, cette persévérance opiniâtre, qui procurent à des nations voisines, des établissements qui manquent à la France. 
Nous les aurons; car, suivant la remarque de Voltaire: Le Français arrive à tout ce qui est bien; mais il y arrive tard. On commence chez nous par blâmer ce qui est hardi, et l'on finit par l'imiter.

Textual changes made to the chapter 'Des débouchés' in the Traité regarding one of the implications of the Law of Markets - that to encourage 'la consommation' is erroneous policy - require attention in evaluating Forget's position. The early editions mention both 'productive' and 'unproductive' consumption; the 1819 edition is simplified to suggest only the latter:

Par une quatrième conséquence du même principe, on concevra que ce n'est point favoriser le commerce que d'encourager la consommation; car il s'agit bien moins de donner l'envie de consommer que d'en procurer les moyens; et nous avons vu que la seule productions fournit ces moyens $[1814,1817$ : et nous avons vu que la production, qui donne les moyens de consommer suffit pour que la consommation ait lieu, soit reproductivement, soit improductivement, puisque le fruit de cette production serait perdu s'il n'était employé, et que le retard même de son emploi est une perte.] Aussi ce sont les mauvaises administrations qui excitent à consommer: les bonnes excitent à produire.

$(1814,1: 156-7 ; 1817,1: 154 ; 1819 a, 1: 163)$

We come now to the main issue at hand, that the 1826 version of this passage is completely rewritten, alluding to the need to develop tastes and needs thereby stimulating consumption:

Par une quatrième conséquence du même principe, la consommation pure et simple, celle qui n'a d'autre objet que de provoquer de nouveaux produits, ne contribue point à la richesse du pays. Elle détruit d'un côté ce qu'elle fait produire d'un autre côté. Pour que la consommation soit favorable, il faut qu'elle remplisse son objet essentiel, qui est de satisfaire à des besoins. . . .

Pour encourager l'industrie, il ne suffit pas de la consommation pure et simple; il faut favoriser le développement des goûts et des besoins qui font naître parmi les populations l'envie de consommer; de même que, pour favoriser la vente, il faut aider les consommateurs à faire des gains qui les mettent en état d'acheter. Ce sont les besoins généraux et constans d'une nation qui l'excitent à produire, afin de se mettre en pouvoir d'acheter, et qui par là donnent lieu à des consommations constamment renouvelées et favorables au bien-être des familles.

(1826a, 1: 191-3; emphasis added)

How far does this lend support to the Forget thesis?

It is apparent that Say's context here is of a developmental nature directed at the encouragement of production; it is to this end that policy should seek 
to stimulate 'les besoins généraux et constans'. We are back to something akin to overcoming constraints on activity imposed by the desire for leisure. The developmental context is further confirmed in a note accompanying the text regarding final consumption:

Je sais fort bien que l'objet essentiel de la production est de satisfaire les besoins de l'homme; je voulais seulement ajouter que lorsqu'elle est improductive, elle n'est accompagnée d'aucun autre avantage; et que par conséquent, si l'on veut lui trouver des avantages, il faut préalablement faire naitre les besoins. Alors il y a un développement plus grand des facultés de l'homme, plus de capacité pour produire et pour jouir, plus de civilisation, et, comme il serait facile de le prouver, plus de facultés morales et intellectuelles.

(194n.; emphasis added)

No mention is made in all this of the entrepreneur as such. Indeed, in the formal discussions of the Traité and the Cours complet of limits-to-growth, entrepreneurship as a scarce factor does not appear (p. 124). The striking passage of 1826 regarding the need to stimulate 'des goûts et des besoins', I conclude, is unrelated to the creation of new sales opportunities in an advanced economy. If output expands then the demand side will look after itself, as is made quite clear by the text that follows (in all editions) regarding the almost automatic expansion of aggregate demand upon expansion of output, coupled with a presumption of a relatively easy allocative adjustment in response to market signals:

Après avoir compris que la demande des produits en général est d'autant plus vive que la production est plus active, vérité constante malgré sa tournure paradoxale, on doit peu se mettre en peine de savoir vers quelle branche d'industrie il est à désirer que la production se dirige. Les produits créés font naître des demandes diverses, déterminées par les moeurs, les besoins, l'état des capitaux, de l'industrie, des agens naturels du pays; les marchandises demandées présentent [1819, 1826: les plus demandées sont celles qui présentent], par la concurrence des demandeurs, de plus forts intérêts pour les capitaux qui y sont consacrés, de plus gros profits pour les entrepreneurs, de meilleurs salaires pour les ouvriers; et ces moyens de production, attirés par de tels avantages, affluent naturellement vers ce genre d'industrie. [1826: et ce sont celleslà qui sont produites de préférence.]

(1814, 1: 157-8; 1817, 1: 155; 1819a, 1: 164; 1826a, 1: 193-4)

Our conclusion is scarcely surprising, once we recall that Say did not take a Knightean approach to uncertainty. One would scarcely expect to find great weight attached to uncertain markets in the general Law of Markets context. To take Forget's position is, in fact, to imply that Say did not maintain the Law in any serious manner, thereby throwing out the proverbial baby 
including Say's careful rationalizations of the rapid disbursement of money funds in normal conditions.

\section{Questions of priority: Say and James Mill}

We return to the central theme of this chapter. In James Mill's review of Lauderdale's Inquiry of 1804, we already find many of the elements playing a part in the later debate, including a categorical denial of the relevance of hoarding in a modern economy:

If [a merchant] cannot employ what he saves with any advantage, he will not save it. No one thinks of accumulating dead stock. We have heard in times of ignorance and insecurity of men who accumulated money, which they neither lent nor employed. We have no such misers, however, now-a-days. And no man saves any part of his income which he has not a prospect of employing with advantage.

(Mill 1804: 13)

Drawing upon Smith's dictum 'what is annually saved is as regularly consumed as what is annually spent, and nearly in the same time too', Mill refuted Lauderdale's fears of the depressing effects on demand of a transfer from consumption expenditure to savings, while singing the praises of accumulation; the justice of Lauderdale's reference to the tendency to accumulate as a 'baneful passion' is questioned, as also are his fears, as Mill phrased it, that 'parsimony' might 'accumulate faster than employment can be procured for active stock': 'We believe that a country must be placed in very peculiar circumstances to admit of this accident ever happening' (13-14).

In Mill's reaction in the same journal to the 1803 Traité, no reference is made to the chapter 'Des Débouchés', but a translation is given of the formulation in Book IV, Chapter V, which in the later editions Say absorbed into his central discussion. On this material Mill remarked favourably: 'The manner in which our author corrects prevailing errors may be exemplified by what he advances respecting an important case, the relation between consumption and production' (Mill 1805: 419). Similarly, he reproduced Say's criticism of the emphasis in Physiocratic literature on the desirability of high consumption, in all of which be found Say to be directly in the Smithian tradition:

he understands the doctrines of Smith better than almost any other author. He has a very clear discernment of the bearings, tendency and application of those doctrines; in several instances he has very happily extended those applications, and in many others has rectified popular mistakes, and removed misapprehensions.

In his Commerce Defended of 1808, James Mill rejected William Spence's doctrine relating to the social desirability of landlords' luxury expenditure 
(Spence 1807). The process of savings entailed (productive) consumption and self-interest assured against the presence of unsold stocks:

Let [Spence] rest in perfect assurance, that the whole annual produce of the country will be always very completely consumed, whether his landholders choose to spend or to accumulate. No portion of it will be left unappropriated to the one species of consumption, or to the other. No man, if he can help it will let any part of his property lie useless and run to waste. Nothing is more clear, than that the self-interest of men, ever has impelled and ever will impel them, with some very trifling exceptions, to use every particle of property which accrues to them either to the purpose of immediate gratification, or of future profit. That part, however, which is destined for future profit, is just as completely consumed, as that which is destined for immediate gratification.

(Mill 1808: 71)

As in 1805, Mill cited Say (Say 1803, 2: 367n.) on the folly of any concern to stimulate expenditure: 'J'ai connu un jeune homme qui fesait voler par la fenêtre, les flacons de crystal à mesure qu'il les vidoit; il faut, disait-il, encourager les manufactures' (Mill 1808: 76n.).

As in Smith's formulation, the emphasis in 1808 is not on the net addition to the stock of capital goods created by savings, but rather on the process of savings. Mill, however, did introduce the supplementary theorem formally treated apart from the principle that saving entails consumption - that 'the production of commodities creates, and is the one and universal cause which creates a market for the commodities produced' (81; emphasis added). This formulation was designed to refute the notion attributed to the Physiocrats that capital and output might 'increase too fast' since there is 'a market for a given quantity of commodities, and if you increase the supply beyond that quantity you will be unable to dispose of the surplus' (80). Mill's Law of Markets is thus phrased with an eye to secular expansion and states that demand cannot exist without production since production generates the income with which commodities are purchased - a Keynesian-type proposition - but, further, that not only is the 'power of purchasing' expanded by increase in production but also so are the 'actual purchases of the nation':

The production of commodities creates, and is the one and universal cause which creates a market for the commodities produced.... It is obviously ... the collective means of payment which exist in the whole nation that constitute the entire market of the nation. But wherein consist the collective means of payment of the whole nation? Do they not consist in its annual produce, in the annual revenue of the general mass of its inhabitants? But if a nation's power of purchasing is exactly measured by its annual produce ... the more you increase the annual produce, the more by that very act you extend the national market, the power of purchasing and the actual purchases of the nation. Whatever 
be the additional quantity of goods therefore which is at any time created in any country, an additional power of purchasing, exactly equivalent, is at the same instant created; so that a nation can never be naturally overstocked either with capital or with commodities; as the very operation of capital makes a vent for its produce.

The 'demand of a nation', Mill concluded, 'is always equal to the produce of a nation' (83).

Mill's position that increased incomes are 'always' spent might appear to be an empirical observation which allows for the (exceptional) possibility in practice of an excess demand for money to hold. But he goes on to recommend for greater clarity of thought that one envisage the economy in barter terms; and this suggests a much stronger version of the Law of Markets, that version according to which the excess demand for money is zero under all circumstances, money per se having no utility:

the idea of money frequently tends to perplex. When money is laid out out of the question, is it not in reality the different commodities of the country ... which are annually exchanged against one another? Whether these commodities are in great quantities or in small, that is to say, whether the country is rich or poor, will not one half of them always balance the other?... And is this a market that can ever be overstocked?

To preclude general excess supply still allows partial excess:

a nation may easily have more than enough of any one commodity, though she can never have more than enough of commodities in general. The quantity of any one commodity may easily be carried beyond its due proportion; but by that very circumstance is implied that some other commodity is not provided in sufficient proportion.

But ' $[w]$ henever this balance is properly preserved, there can be no superfluity of commodities, none for which a market will not be ready'. And, at least in the absence of 'injudicious tampering of government' and 'disorders' to commerce produced by wars, misallocations would be rapidly corrected.

Mill described the proposition that 'the production of commodities creates ... a market for the commodities produced', assuring the absorption of expanded supplies to any degree, as 'paradoxical' (81), and this may have left readers with the impression that a truly original statement was at stake. In an anonymous review of his own Commerce Defended, Mill praised his discussion of the Law as 'an excellent specimen of Mr. Mill's acuteness and powers of abstraction' (cited in Baumol 2003: 48; see also Thweatt 1980: 468). Now Jacob Hollander represented Mill as the 'originator' of the Law 
on the grounds that there is very little on the matter in the 1803 edition of the Traité (Hollander 1928: lxxixf.). (For more recent verdicts pointing to Mill's precedence, see Thweatt 1979: 92-3; 1980; Kates 1997: 196; Baumol 2003: 46.) But if we recall that the 1803 edition contains much of relevance in addition to the materials in the brief chapter 'Des Débouchés' and that Mill in the 1805 review cited the relevant chapters, temporal priority appears to be Say's (see also Lambert 1956: 13; Schumpeter 1954: 491n.; Spengler 1960 [1945]: 191; Winch 1966: 34; Sowell 1987b: 250).

There are further complications that must be dealt with to allow us to arrive at a final conclusion. Thus it has been said that since Mill introduced the condition that the composition of output must reflect the tastes of consumers and investors, his statement stands far and away above that of Say (Stigler 1965: 313). Now we have in fact seen that, as early as 1803 , Say recognized the necessity for resource reallocation to reflect the pattern of demand and the likelihood of rapid correction of any maldistribution at least in normal conditions (above, p. 192). This perspective, we also recall, is much emphasized in Say's 1824 response to Sismondi (above, p. 215). There is no difference here and conceivably Mill adopted the condition from Say.

There is a related proposition by Stigler, that in his Principles Ricardo 'developed the law of markets along Mill's line' with 'each recipient of money spend[ing] it promptly', but also proposing that 'no matter how large the accumulation of capital, all commodities could be sold for prices equal to costs of production, provided the commodities suited consumers' tastes' (317). ${ }^{10}$ 'In this form', Stigler concluded, 'the law of markets is no longer [the] truism' - such as he ascribed to Say's 1814 version - that assuming money receipts are promptly spent 'an offer of one commodity is always an implicit demand for another', but the non-tautological proposition 'that general equilibrium of the economy with prices equal to costs (including "profits"), is compatible with any level of real income' (317-18). ${ }^{11}$ I question this reading on the grounds that Say did specify in 1814 the equilibrium proposition entailing cost-covering prices, albeit that the context happens to be not one of misallocation but of an inadequacy of 'counter-commodities' (see above, pp. 196-7). It is very likely, especially considering his doctrine of services, that Say took this condition for granted whenever he did not explicitly spell it out.

\section{Summary and conclusion}

Ricardo's friendship with James Mill began after a reading of Commerce Defended containing the reference to the 1803 Traité. But he was already familiar at first hand with this edition before the appearance in 1814 of the second. (He was sent a copy by Say in December 1814 (Ricardo 1951-73, 6: 160), whereas Mill wrote to him in November regarding 'Mons. Say, the author of the excellent book with which you are well acquainted'; 156.) Now for the Law of Markets Ricardo accorded Say priority, an assertion that 
must be carefully justified since it has been denied in some recent commentary (above, p. 22).

It is to Say's 'doctrine of demand being limited by production' that Ricardo refers in correspondence with Trower of 26 December 1820 (1951-73: 8: 258). Say's temporal priority over Mill is asserted also in the Funding System and this with reference to unrestricted sales at cost-covering prices, the very issue that so impressed Stigler:

Now the doubts of those who speak of the mischievous effects of the great accumulation of the sinking fund, proceed from an opinion they entertain that a country may possess more capital than it can beneficially employ, and that there may be such a glut of commodities, that it would be impossible to dispose of them on such terms as to secure to the producers any profits on their capitals. The error of this reasoning has been made manifest by M. Say, in his able work Economie politique, and afterwards by Mr. Mill, in his excellent reply to Mr. Spence, the advocate of the doctrine of the Economistes. They show that demand is only limited by production; whoever can produce has a right to consume, and he will exercise his privilege to the greatest extent. They do not deny that the demand for particular commodities is limited, and therefore they say, there may be a glut of such commodities, but in a great and civilized country, wants, either for objects of necessity or of luxury, are unlimited, and the employment of capital is of equal extent with out ability of supplying food and necessaries for the increasing population, which a continually augmenting capital would employ.

(1951-73, 4: 178-9)

In the Principles itself are to be found explicit attributions of priority. Thus, Ricardo writes of the chapter 'Des Débouchés' in the 1814 Traité that it contained 'some very important principles, which I believe were first explained by this distinguished writer' (1951-73, 1: 7n.), a statement implying that the 1814 version contained principles first adumbrated in 1803. ${ }^{12}$ And in his chapter 'Effects of accumulation on profits and interest' it is to Say's analysis to which Ricardo refers in contesting Smithian competition of capitals: 'M. Say has ... most satisfactorily shewn, that there is no amount of capital which may not be employed in a country, because demand is only limited by production' (290). ${ }^{13}$ Finally, in opposing Smith's proposition that 'the more disposable capitals are abundant in proportion to the extent of employment for them, the more will the rate of interest on loans of capital fall', Ricardo appealed to 'M. Say's principle' (290n.). ${ }^{14}$

$$
\text { * * * }
$$

Ricardo's formal ascriptions of priority to Say are one thing and interpretation and use of the doctrine quite another. Let us explore this complication. 
In the Traite of 1826 and the Cours complet we find Say still working with Smithian increasing competition of capitals despite his recognition in 1819, under pressure from Ricardo, that this argument conflicted with the Law of Markets (above, pp. 64-5). There is also Say's notion of increase in 'countercommodities' as solution to excess supply, of which Ricardo wrote critically to Malthus on 4 September 1820 :

I have seen Say's letters to you; it appears to me that he has said a great deal for the right cause, but not all that could be said. In one point I think he falls into the same error as Torrens in his article in the Edin. Rev. [Torrens 1819: 471]. They both appear to think that stagnation in commerce arises from a counter set of commodities not being produced with which the commodities on sale are to be purchased, and they seem to infer that the evil will not be removed till such other commodities are in the market. But surely the true remedy is in regulating future production, - if there is a glut of one commodity produce less of that and more of another but do not let the glut continue, till the purchaser chuses to produce the commodity which is more wanted. ${ }^{15}$

(1951-73, 8: 227-8)

Similarly, in informal notes on the anonymous pamphlet A Reply to Mr. Say's Letters to Mr. Malthus (1820), Ricardo complained: 'I am as much dissatisfied as the author with M. Say's defence of the principle which both he and I maintain to be true' (1951-73, 10: 410). Perhaps relevant too is Ricardo's remark to Malthus of 24 November 1820 regarding Say:

for the opinions which we hold in common, he does not give such satisfactory reasons as might I think be advanced. In fact he yields points to you, which may almost be considered as giving up the question, and affording you a triumph.

$(1951-73,8: 301-2)$

Ricardo thus distinguished between the principle of the Law of Markets - for which he paid warm tribute to Say - whereby (balanced) growth can proceed at cost-covering prices unchecked by aggregate-demand constraints, and Say's defective 'defence' in terms of 'counter-commodities'. From this perspective, it would appear that Ricardo, despite his ascriptions of priority to Say, would have considered James Mill's proposition whereby 'the production of commodities creates ... a market for the commodities produced' (above, p. 220) more acceptable than Say's 'quand une nation a trop de produits dans un genre, le moyen de les écouler est d'en créer d'un autre genre' (above, p. 190).

The counter-commodity case, it has been properly noted, allows excess supply which is only corrected if and when other products are produced, unlike the Mill formulation, a contrast leading Chipman to ascribe to Mill, not Say, priority 'for the sharp and excessively doctrinaire version' of the Law 
of Markets (Chipman 1965: 709n.; see also Thweatt 1980: 469). Chipman's evaluation can also be justified on broader grounds. Whereas James Mill, like Smith, asserted loosely that "no man, if he can help it will let any part of his property lie useless and run to waste', for which reason 'the whole annual produce ... will always be very completely consumed' (above, p. 220), Say sought more seriously to rationalize the prompt expenditure of sales proceeds. This he did in terms both of avoidance of loss of interest and of the 'perishability' of the value of money. But above all, in order to account for observed features of general depression, he readily allowed that the normal rule gave way in conditions of expected price deflation. And all this as early as 1803 (above, p. 194), though it is true that over the years the insistence on the Law only as a long-term propositon is much amplified. Here lies the true difference between Mill and Say, though Say sometimes fell into Mill-like extravagance as in his 1819 entry under 'PRODUCTION' (above, p. 201).

This contrast cannot be drawn in such sharp terms between Say and Ricardo, notwithstanding the latter's objection to the counter-commodity analysis. As we know, Say in the Lettres à M. Maltbus - much to Malthus's delight - charged that Ricardo failed to allow for hoarding and contemporary features of general depression (above, p. 207). Here both Say and Malthus went too far, since Ricardo too recognized temporary excess demand for money in discussing the effects of reductions in money supply, and applying the allowance in recommendations relating to credit flexibility and the return to gold. For this, Say made amends in his 1826 paper on the British commercial crisis, as we have shown. But the fact remains that Ricardo unlike Say (and J. S. Mill) did not feature aggregate-demand contraction as a possible cause of depression, but only as its accompaniment. 


\section{Say and the classical canon An overview}

\section{John Stuart Mill's conciliatory position}

J. S. Mill rejected the notion of a paradigmatic contrast between the British and French traditions represented by Ricardo and Say respectively. After receiving from Say a gift of the Cours complet he opined that definitional and organizational differences did not imply substantive doctrinal or methodological differences; he himself had profited even from Say's 'speculations', which neither conflicted with those of the 'abstract' British writers to whom Say objected nor implied significant policy differences:

You will hardly be surprised that I should not quite concur in the whole of your strictures on those whom you call the 'économistes politiques abstraits'; though I am forced to admit that they have frequently occupied public attention, to the great detriment of the science, with discussions of mere nomenclature and classification, of no consequence except as to the manner of expressing or of teaching the principles of the science; and that they have occasionally generalised too far, by not taking into account a number of the modifying circumstances, which are of importance in the various questions composing the details of the science. I have myself derived several most important corrections of my speculative views from your work, and from the reflections which it suggested. I am happy to find that there is much less in your principles, than I thought there was, which is positively at variance with the rigidly scientific economists of this country. I believe that their principles when duly modified, constitute a deeper and more searching analysis of the phenomena of wealth than yours, but that they are not materially different in their practical result.

(Mill to Say, 2 March 1830; in Mill 1963-91, 32: 10)

We have also an obituary notice by Mill in the Examiner, dated 25 November 1832, praising Say's balanced approach incorporating both theoretical and empirical matter: 
The invaluable branch of knowledge to which the greatest of his intellectual exertions were devoted, is indebted to him, amongst others, for those great and all-pervading truths which have elevated it to the rank of a science. . . . Nor was M. Say a mere political economist; else had he been necessarily a bad one. He knew that a subject so 'immersed in matter' (to use the fine expression of Lord Bacon) as a nation's prosperity, must be looked at on many sides, in order to be seen rightly even on one.

(Mill 1963-91, 23: 524)

The Principles cites warmly Say's contribution to the excess-demand issue with special reference to the case against the 'systems' of Malthus, Sismondi and Chalmers (Mill 1963-91 [1848], 3: 575-6). There is the commendation of Say along with Ricardo for the proposition 'demand for commodities is not demand for labour' relating to the accumulation process (Mill 1963-91 [1848], 2: 78; see above, p. 176). And in value theory, Mill was impressed by Say's solution to the 'paradox, of two things, each depending upon the other' that demand varies inversely with price but price rises as demand increases - involving the equation of demand and supply (Mill 1963-91 [1848], 3: 466; see above, p. 101).

Our study substantiates Mill's evaluation with respect to methodology, and goes a considerable way in his direction with respect to doctrine. But here matters become complicated because Say's adherence to key features of the classical canon is frequently 'reluctant' and because of the retention of conflicting Smithian elements. In this chapter I shall summarize the reasons for taking this position and, in the final chapter, seek to understand the common impression that Say's substantive objections to the Ricardians on matters relating to doctrine and method hardened after Ricardo's death in 1823 .

\section{Methodology}

In August 1815 Say sent Ricardo a presentation copy of his Catéchisme d'Economie politique, which he described as containing 'en style familier l'exposé de nos grands principes' (Ricardo 1951-73, 6: 245). Extensive common ground is evidently taken for granted. And this is confirmed in a letter of 10 September 1815 acknowledging receipt of a gift copy of the Essay on Profits, where Say expressed a favourable opinion, in general terms, regarding both matters of principle and trade policy: 'Je dois vous dire ... que je partage votre opinion dans tous les principes que vous établissez, et que j'ai été fort aise de trouver de nouveaux et solides argumens en faveur de la liberté du commerce' (Say, in Ricardo 1951-73, 6: 270). As for method, there is hearty commendation of Ricardo's establishment of principles in the Essay, with the qualification, in line with James Mill's recommendation, that some applications and examples would have been desirable: 
Je pense bien, comme M. Mill, que si vous aviez developpé chaque proposition abstraite, par quelques applications et par des exemples, vous auriez été plus facilement entendu. Mais je ne conçois pas que vous puissiez croire cette tâche au dessus de vos forces, puisque ce que vous avez fait, j'entends l'établissement des principes, était précisément ce qu'il y avait de plus difficile et ce qui exigeait la plus grande exertion de ce que vous me permettrez d'appeler un génie très profond.

In a version of this letter dated 2 December, but not actually sent, Say encouraged Ricardo to follow Mill's advice and proceed to a fully fledged elaboration of his ideas: 'Je me bornerai donc à souhaiter, avec M. Mill, que vous développiez vos idées dans un ouvrage ad hoc. J'y gagnerai, et le public aussi' (274).

This warm reaction in private correspondence is not apparent in the 'Discours Préliminaire' to the Traité of 1817 where Say refers dismissively, as in the 1814 version, to various 'brochures' that had appeared in France and Britain since 1776 - he mentions Thornton (1802) but not Ricardo's Essay of 1815 - all characterized by concern with specific policy objectives but lacking a body of universally valid principles:

La plupart sont des écrits polémiques, où des principes ne sont posés que pour servir d'appui à une thèse donnée; je n'en connais aucun qui contienne un corps de doctrine tout-à-fait indépendant des circonstances, également fait pour vivre dans tous les temps et pour être utile dans tous les pays.

(Say 1814, 1: lix-lx; 1817, 1: lvi-lvii; emphasis added)

The 1819 version is relegated to a note and reworded to allow for pamphlets that had appeared expounding sound principles though biased to support the particular author's objectives:

La plupart sont des écrits polémiques, où des principes ne sont posés que pour servir d'appui à une thèse donnée; mais où l'on peut cependant recueillir des faits précieux, et même des principes sains, lorsqu'ils sont favorables au but principal de leurs auteurs.

On the other hand, the case for an exposition of general principles - a 'complete' body of such principles no less - again appears in the text itself and reappears in 1826 :

Cependant on n'avait pas encore de véritable traité d'Économie politique; on n'avait point d'ouvrages où de bonnes observations fussent ramenées à des principes généraux qui pussent être avoués de tous les hommes judicieux; où ces observations et ces principes fussent complétés et coordonnés de manière à se fortifier les uns par les autres, et à pouvoir être étudiés avec fruit dans tous les temps et dans tous les lieux.

(1819a, 1: 1xi; 1826a, 1: lxxvi-lxxvii) 
In these last two editions Say adds that '[d]epuis les premières éditions qui en ont été faites, plusieurs écrivains, dont quelques-un jouissent d'une juste célébrité' - he refers explicitly to Ricardo and Sismondi (and makes condescending mention of Marcet) - 'ont publié de nouveaux traités d'Économie politique' (1819a, 1: lxiv; 1826a, 1: lxxx). He himself did not feel obliged to comment on such productions in any detail and decide whether they contained 'une exposition claire, complète et bien liée des principes sur lesquels repose cette science'; he had benefited from them in some respects and found them wanting in others:

plusieurs de ces ouvrages renferment des vérités et des développemens propres à avancer beaucoup la science, et . . . je me suis perfectionné à leur lecture; mais j'ai pu, comme tout écrivain en a le droit, remarquer en quoi quelques-uns de leurs principes, spécieux au premier abord, sont démentis par une étude plus scrupuleuse des faits.

(1819a, 1: lxiv; 1826a, 1: lxxxi)

Now all of this points to the desirability of developing a corpus of general, indeed universally valid, principles acceptable to all 'judicious' men. This position is further confirmed in the Cours complet, where Say contrasts economic science and statistics:

De là les différences qui caractérisent ces deux genres d'études: l'une (l'économie politique) appartient à tous les temps, à tous les lieux. L'autre (la statistique) n'enseigne point de vérités générales, et s'attache à constater les phénomènes à mesure qu'ils arrivent. Il est impossible de ne pas ajouter au mot de statistique, ceux-ci: de tel endroit et de telle époque. On ne peut pas dire absolument: Tel ouvrage enseigne la statistique; car la statistique du jour de demain, de l'année prochaine, n'existe point encore; tandis que l'on peut dire: Tel ouvrage contient les vérités fondamentales et invariables de l'économie politique.

(1843 [1828-9]: 535)

In his Commentary on Storch, Say refers to the establishment of exchange value according to 'des lois naturelles connues' (1848 [1823]: 332). The growth, distribution and consumption of riches obeyed 'des lois constantes et dont on peut décrire l'action et assigner les effets'; and Adam Smith followed by ‘tous les auteurs de quelque réputation' - by concerning himself only with scarce goods possessing exchange value, 'a fait . . . de l'économie politique, non plus une science conjecturale et hypothétique, mais une science positive, agissant sur des grandeurs connues et susceptibles d'appréciations rigoureuses'. In his 1826 review of Sismondi's Nouveaux Principes, Say also refers to 'les lois naturelles de l'économie politique découvertes par les bons auteurs' (see below, p. 284). And in further discussion in the 'Discours préliminaire' of the potential for scientific progress in political economy, Say even declares that the body of knowledge constituting this 
science - again unlike statistics - had the potential to become 'complete' provided that its laws, reflecting 'les faits généraux', are soundly based on observation of properly observed particular facts thus creating 'des fondemens inébranlables':

Nos connaissances en Économie politique peuvent être complètes, c'està-dire, que nous pouvons parvenir à découvrir tous les faits généraux dont l'ensemble compose cette science [1826: à découvrir toutes les lois qui régissent les richesses]: il n'en saurait être de même de nos connaissances en Statistique ... un exposé de faits plus ou moins incertains et ... incomplets. ...

L'Économie politique, au contraire, est établie sur des fondemens inébranlables, du moment que les principes qui lui servent de base, sont des déductions rigoureuses de faits généraux incontestables. Les faits généraux sont à la vérité fondés sur l'observation des faits particuliers; mais on a pu choisir les faits particuliers les mieux observés, les mieux constatés, ceux dont on a été soi-même le témoin; et lorsque les résultats en ont été constamment les mêmes, et qu'un raisonnement solide montre pourquoi ils ont été les mêmes, lorsque les exceptions mêmes sont la confirmation d'autres principes aussi bien constatés, on est fondé à donner ces résultats comme des faits généraux positifs [1826: des lois générales], et à les livrer avec confiance au creuset de tous ceux qui, avec des qualités suffisantes, voudront de nouveau les mettre en expérience.

(1814, 1: xix-xx; 1817, 1: xiii-xv; 1819a, 1: xvii-xviii; 1826a, 1: xv-xvii)

Say immediately goes on to caution that any new 'particular' fact not yet accounted for cannot in and of itself undermine a properly based general law:

Un nouveau fait particulier, s'il est isolé, si le raisonnement ne démontre pas la liaison qu'il a avec ses antécédens et ses conséquens [1814, 1817: avec les effets qu'on lui attribue], ne suffit point pour ébranler un fait général; car, qui peut répondre [1814: car on ne peut s'assurer] qu'une circonstance inconnue n'ait pas produit la différence qu'on remarque entre les résultats de l'un et de l'autre [1826: entre deux résultats]?'

In this context, Say identified political economy with the 'exact sciences', composed of 'un petit nombre de principes fondamentaux et d'un grand nombre de corollaires, ou conséquences de ces principes'; and again he entertained the prospect of achieving a sort of 'perfection', where 'proof' regarding the corollaries or consequences flowing from the principles would be unnecessary:

Ce qu'il y a d'important pour les progrès de la science, c'est que les principes soient solidement déduits [1826: découlent naturellement] de l'observation.... Et ... plus cette science sera perfectionnée et 
répandue, et moins on aura de conséquences à tirer des principes, parce que ces conséquences sauteront aux yeux; tout le monde sera en état de les tirer [1826: trouver] soi-même et d'en faire des applications. Un Traité d'Économie politique se réduira alors à un petit nombre de principes, qu'on n'aura pas même besoin d'appuyer de preuves, parce qu'ils ne seront que l'énoncé de ce que tout le monde saura, arrangé dans un ordre convenable pour en saisir l'ensemble et les rapports.

(1814, 1: xxix-xxx; 1817, 1: xxiv; 1819a, 1: xxvii-xxviii; 1826a, 1: xxix-xxx)

Reliance on general principle in the deductive process alluded to here is illustrated by the manner he himself had arrived at the solution to the mystery regarding 'riches': 'Cette démonstration poussée à la dernière évidence par l'étude des principes fondamentaux, a donné la clef d'une proposition qui semblait paradoxale', that riches though composed of values rise when cost prices are cheapened by new technology (Chapter 4, passim).

It is noteworthy that Say proudly claimed priority for the formal presentation of principles in responding to Malthus's criticism in his Definitions (above, p. 105):

Enfin, M. Malthus peut-il reprocher à un auteur de n'avoir pas fait concorder ce mot [utilité] avec tous les autres, lorsque cet auteur est le premier qui, dans un Épitome joint à son ouvrage, a marqué les liaisons qui rattachent chacun de ses principes à tous les autres?

(Say 1827a: 496; see on this matter, Pullen 1989: liii-liv)

$$
\text { *** } *
$$

The central role attributed to general principle - 'les faits généraux, les lois générales'1 and 'la chaîne qui lie les effets aux causes' - is further emphasized by Say in the body of the Traité when discussing the proposition that domestic trade is quantitatively more significant than foreign trade. Notable here is the disdain shown towards mere data gathering:

L'évaluation exacte en serait impossible à faire, même dans les pays où les calculs de ce genre sont en grande vénération. Elle serait, du reste, bien superflue; et en général les évaluations statistiques, qui, fussentelles exactes, ne sont jamais permanentes, ont en elles-même peu d'utilité. Ce qui est vraiment utile, c'est de bien connaître les faits généraux, les lois générales, c'est-à-dire, la chaîne qui lie les effets aux causes. Cela seulement peut indiquer la conduite qu'il faut tenir [1817: les mesures qu'il convient de prendre] dans chaque situation où l'on se trouve. [1814: . . . les faits généraux, c’est-à-dire, les résultats invariables des circonstances données; ce sont eux qui indiquent les mesures qu'il convient de prendre dans chaque situation où l'on se trouve.]

(1814, 1: 83n.; 1817, 1: 83n.; 1819a, 1: 85n.; 1826a, 1: 102n.) 
In 1817 and thereafter Say goes on to reduce the role of 'statistics' to that of providing examples of, or 'proving', or 'confirming', the principles which must themselves be established independently:

La statistique ne peut fournir à l'économie politique que des exemples pour faire comprendre des principes [added 1819, 1826: qui doivent être démontrés sans elle], ou leur servir de preuves [1826: ou pour les confirmer]. Elle ne saurait fonder des principes. Ceux-ci ne peuvent être fondés que sur la nature des choses.

He adds that '[1]a meilleure statistique ne fait connaître que la quantité des choses'.

Say was, in effect, following Adam Smith in rejecting 'inductive' procedures purporting to draw causal relations from observation of raw data (see Hollander 1979: 26-9). This position - and the qualified role allowed statistics as, at the very most, capable of 'confirming' causal relations - is succinctly formulated in the Cours complet (Say 1843: 536-7) and in a striking paper devoted to the subject:

La statistique peut énoncer le fait, et ne saurait l'expliquer; et ceux qui tentent de l'expliquer sans connaître l'économie des sociétés, sont convaincus d'absurdité à tout moment. Prétendre que les faits constatés par la statistique sont le fondement de l'économie politique, équivaut à prétendre que la quantité d'eau-de-vie produite par les distillateurs suffit pour nous apprendre comment s'opère la distillation. . . .

Faudrait-il conclure de cette vue générale du sujet, que la statistique ne peut rendre aucun service à l'économie politique? Cette conclusion serait trop absolue. La statistique ne nous apprend pas l'enchaînement des faits, c'est-à-dire les causes et les résultats de ce que nous voyons; mais en faisant passer devant nos yeux plusieurs phénomènes successivement, elle peut jeter quelque jour sur leur action réciproque; elle peut servir de confirmation à des vérités, dont la preuve résulte de l'étude que nous faisons de la nature de chaque chose.

(Say 1827b: 534-5)

In this paper and in the Cours complet Say also provides a more specific account of what he intended by the 'political arithmetic' to which he objected in general terms in the 'Discours préliminaire' of the Traité (1814, 1: xx; 1817, 1: xiv; 1819a, 1: xvii; 1826a, 1: xvi). He had in mind the manipulation of raw data to arrive at causal relations, a procedure that could be no better than more direct inductions:

On a pu s'apercevoir que les moyens qu'on met en usage pour se procurer des données statistiques, sont de deux sortes. Tantôt on emploie l'observation directe, comme lorsque l'on constate la population 
d'un endroit par un dénombrement, ou bien la quantité de marchandises exportées ou importées par l'inspection des registres des douanes. Tantôt on cherche la vérité par les calculs de l'arithmétique politique. C'est ainsi que l'on part de certaines données pour arriver au moyen de l'induction, à d'autres données auxquelles on ne peut parvenir directement. . . .

On voit que, dans l'arithmétique politique, comme dans la statistique, tout dépend de l'exactitude des bases. Un grand appareil de chiffres ne suffit pas pour établir une vérité. Quand une première observation est défectueuse, les multiplications et les divisions que l'on bâtit sur ce fondement éloignent les calculateurs de la réalité, au lieu de les en rapprocher.

(Say 1827b: 545-6; 1843: 539-40)

For all that, Say had constructive suggestions to offer regarding the most useful sorts of census data to collect.

We return to Say's identification of political economy with the 'exact sciences' (above, p. 230). ${ }^{2}$ Given his very strong stance in favour of 'deductive' method, it comes as no surprise to find him in the Traité of 1817 and thereafter specifying more precisely physics:

Dans les sciences qui ne font que recueillir et classer des observations, comme la botanique, l'histoire naturelle, il faut lire tout; dans les sciences qui déduisent [1826: où il s'agit de déduire] des lois générales de [1826: de l'observation des] faits particuliers, comme la physique, l'économie politique, il ne faut lire que deux ou trois ouvrages . . .

(1817, 2: 126-7n.; 1819a, 2: 148-9n.; 1826, 2: 328n.)

In the Cours complet the precise parallel is with physiology, the discussion setting out in terms of a blood-circulation analogy (1843: 536). And we shall presently encounter a mechanical approach towards price equilibration (below, p. 237).

Yet some of Say's formulations seem to invite a very different reading, one pointing to Baconian 'induction' and 'experiment' as the key. We shall give two late instances, from the Revue Encyclopédique and from the Encyclopédie Progressive:

C'est la Méthode expérimentale de BACON, appliquée aux sciences morales et politiques. On sait quels étonnans progrès lui doivent les sciences physiques. L'économie politique lui doit ses seuls progrès véritables. SMITH fonde en général ses raisonnemens sur un fait, et non sur une proposition générale sujette à controverse; et comme il était bon observateur et raisonneur judicieux, il se trompe rarement; si rarement, qu'il 
convient d'y regarder à deux fois, avant de se mettre en opposition avec lui. Sans doute quelques faits lui ont échappé; ses analyses sont dans certains cas incomplètes; il a laissé de côté des parties de la science, et l'arrangement de son livrre laisse beaucoup à désirer; mais, dans les détails, sa méthode est la seule qui puisse conduire avec certitude à la vérité.

(1825: 707n.)

Il est fâcheux pour la science qu'on y introduise des argumentations scolastiques pour remplacer les inductions que suggère au bon sens la nature des choses. Dans les sciences physiques on fonde un principe sur des expériences et des observations et non sur des syllogismes; tout porte à croire que les sciences morales et politiques ne feront des pas assurés que lorsqu'on leur appliquera cette méthode expérimentale, indiquée par Bacon, perfectionnée par Galilée, par Newton, et à laquelle les sciences naturelles doivent les étonnans progrès qu'elles ont faits de nos jours.

(1826b: 273-4)

Passages of this sort, in my view, constitute rhetorical flourishes which, if taken too literally (see, for example, O'Brien 1988: 208), would render meaningless all that Say had insisted upon regarding the building up of general principles as basis for deductive exercises and the derivation of causal relations. Forget has correctly pointed out that 'Say's rhetorical attachment to the inductive method should not be overstated', and that his 'crusade was not against "system building" per se' but designed rather to ensure a proper empirical foundation for his premises (Forget 1999: 125). ${ }^{3}$ All his apparently 'inductive' passages can be read in precisely this manner as referring to the responsible construction of an axiomatic base. Say would have surely applauded the spirit of Leontief's celebrated presidential address at the American Economic Association (Leontief 1971).

Say's identification of political economy with physics is qualified as far as concerns theory application, where the complications created by the vagaries of human behaviour precluded the use of mathematics in problem solving, despite the fact that 'value' - the basic concept - was subject to 'more or less':

Mais ce serait vainement qu'on s'imaginerait donner plus de précision, et une marche plus sûre à cette science, en appliquant les mathématiques à la solution de ses problèmes. Les valeurs dont elle s'occupe, étant susceptibles de plus ou de moins, sont bien du domaine des mathématiques; mais comme elles sont en même temps soumises à l'action des facultés, des besoins et de la volonté des hommes, elles ne sont susceptibles d'aucune appréciation rigoureuse [1814: exacte], et ne peuvent fournir aucune donnée à aucun calcul positif.

(Say 1814, 1: xxx-xxxi; 1817, 1: xxv; 1819a, 1: xxviii) 
The 1814 version concludes by reiterating that no supposed set of initial data could conceivably be valid in any actual application because of the complexity of human action - 'les raisons qui agissent sur les valeurs sont en partie morales, et échappent à toute espèce de fixation’ (1814, 1: xxxi). The editions of 1817 and 1819 restate the general moral: 'L'essentiel en Économie politique, comme dans la physique animale, est la connaissance de l'enchaînement qui lie les causes et les effets. Il n'y a rien de rigoureux dans la nature vivante, et encore moins dans la nature morale' $(1817,1$ : xxv; 1819a, 1: xxviii). A footnote illustrates the complexities (extending beyond the behavioural domaine) which preclude any meaningful forecast of the price of wine, albeit that the principle held good whereby 'le prix des vins de l'année dépendra infailliblement de la quantité des vins qu'il y aura à vendre, comparée avec l'étendue des besoins' (emphasis added).

The 1826 version is subtly different, the variation suggesting a slight weakening of the parallel with physics in that the suitability of mathematical procedure is now said to be only apparent notwithstanding that the units in both domains were 'susceptibles de plus et de moins':

Les valeurs et les quantités dont elle s'occupe, étant susceptibles de plus et de moins, sembleraient devoir entrer dans le domaine des mathématiques; mais elles sont en même temps soumises à l'influence des facultés, des besoins, des volontés des hommes; or on peut bien savoir dans quel sens agissent ces actions diverses, mais on ne peut pas apprécier rigoureusement leur influence; de là l'impossibilité d'y trouver des données suffisamment exactes pour en faire la base d'un calcul.

(1826a, 1: xxx; emphasis added)

The close of this passage again points to application as the problem, and this is confirmed by repetition of the example of forecasting wine prices.

A further instance of the objection to attempts at mathematical precision will be found in the wage-structure discussion:

le total des salaires des médecins doit payer, outre l'intérêt des sommes consacrées à leurs études, celles des sommes consacrées à l'instruction des étudians morts pendant leur éducation, ou qui n'ont pas répondu aux soins qu'on a pris d'eux; car la masse actuellement existante des travaux médicinaux n'a pu exister, sans qu'il y ait eu perte d'une partie des avances consacrées à l'instruction des médecins. Au surplus, une trop minutieuse exactitude dans les appréciations de l'économie politique est sans utilité, et se trouve fréquemment démentie par les faits, à cause de l'influence des considérations morales dans les faits d'économie politique; considérations qui n'admettent pas une précision mathématique. 
For this reason, 'l'application des formules algébriques à cette science est tout-à-fait superflue, et ne sert qu'à la hérisser de difficultés sans objet. Smith ne les a pas employées une seule fois.' The later versions are almost identical (1817, 2: 76-7n.; 1819a, 2: 95n.; 1826a, 2: 261n.).

A statement of the parallel between political economy and experimental physics is provided in Say's informal Commentary on Storch 1823 and summarizes to perfection his position:

Les sciences fondées sur les faits physiques ne sont point toutes des science exactes. Il n'y a dans la physique expérimentale qu'un bien petit nombre de résultats que l'on puisse établir d'avance par le calcul. Les calculs de la mécanique analytique ne sont jamais confirmés par les résultats de la mécanique expérimetale, parce qu'on n'a jamais pu apprécier rigoureusement les frottements, l'élasticité des corps, la résistance de l'air suivant la nature des corps qui le frappent, non plus qu'une multitude d'autres circonstances dont l'influence sur les résultats est fort grande. C'est exactement pour la même raison que l'économie politique n'est point une science exacte, et que ceux qui ont voulu y appliquer les formules algébriques n'ont rien produit d'utile et de vrai. Mais comme science expérimentale elle est éminemment utile; car si elle ne nous enseigne pas jusqu'à quel point exact une cause agit, au moins nous indique-t-elle dans quel sens elle agit, et si cette cause nous éloigne ou nous approche du but désiré: le bonheur de l'espèce. On ne peut pas dire qu'elle n'est pas soumise au calcul, car l'appréciation et le choix des moyens sont des calculs; mais les bases de ces calculs, au lieu d'être des données arbitraires comme dans les mathématiques, sont des faits réels. On est d'autant plus savant en économie politique que l'on connaît mieux les faits qui doivent entrer dans les calculs, et que l'on apprécie mieux l'étendue de leur influence.

It is specifically the need to make allowance in applications for 'disturbing causes', in particular those relating to behaviour, that precludes mathematical precision. This must be emphasized since Say formally did insist upon the possibility of quantification as providing the scientific basis for political economy in the course of his efforts to establish exchangeable value as the 'foundation' of riches, as we have shown in Chapter 4 (on which matter see further below, p. 276). Now while this particular case collapsed once Say altered the terms of reference to deal with real-income flow, accepting Ricardo's non-quantifiable utility terms, he remained quite ready to use mathematical relations in substance if not in form in several theoretical expositions. To illustrate from an observation of 1815 relating to free goods: 'Cette supposition est inadmissible dans son excès, je le sais; mais, ce qui ne l'est pas, ce sont les différents degrés de bon marché (cheapness) qui s'éloignent ou se rapprochent plus ou moins du bon marché absolu' (in Ricardo 1951-73, 
6: 274). Similarly, the effect on saving of a falling profit rate (above, p. 109) is said in 1826 to involve continuous rather than discrete relations: 'En ce casci, comme dans beaucoup d'autres, il n'y a point de causes absolues, mais des effets gradués et proportionnels à l'intensité des causes, et des causes dont l'intensité diminue graduellement à mesure que l'on approche des suppositions extrêmes' (Say 1826a, 2: 337). The geometric representation of the demand-price relation provides a conspicuous instance (above, p. 102). So too does a mechanical analogy in the context of price equilibration in the 1819 edition:

Enfin, quelles que soient les causes générales ou particulières qui déterminent la plus ou moins grande quantité de chaque chose qui est offerte ou demandée, c'est cette quantité qui, dans les échanges, influe fondamentalement sur les prix.... Chaque chose utile ou agréable serait indéfiniment demandée, si la difficulté de l'acquérir, ou le prix, ne mettait une borne à cette demande et ne la restreignait. D'un autre côté, elle serait indéfiniment offerte, si la même limite, le prix, ne bornait l'offre et ne la restreignait; car on ne peut douter qu'en fait de choses susceptibles d'être produites, on offrirait indéfiniment ce qui serait acheté n'importe à quel prix. La demande pousse ainsi la limite du côté de la cherté; et l'offre, à l'autre extrémité de la même ligne, la pousse du côté du bon marché; mais des deux parts les forces diminuent à mesure que la limite s'éloigne, et le point où l'action de ces deux forces vient à se balancer, est celui où s'arrête la limite de la cherté et du bon marché, c'est-à-dire, le prix.

C'est ce qu'on exprime par cette formule: En chaque lieu, à chaque époque, le prix de chaque chose s'élève d'autant plus que la chose est moins offerte et plus demandée; et d'autant moins qu'elle est plus offerte ou moins demandée. Ou par cette autre formule, L'élévation des prix est en raison directe de la quantité demandée, et en raison inverse de la quantité offerte. ${ }^{4}$

(Say 1819a, 2: 16-17)

Finally, although Say did not approach consumer behaviour in terms of quasi-mathematical marginal-utility analysis, he did appreciate the equality in equilibrium between marginal-cost and marginal-utility ratios; and recognised the notion of consumer surplus and its monetary equivalent (above, p. 99).

$$
* * *
$$

We come now to Say's objections to the 'abstract' economists, pre-eminently Ricardo. These amount to an alleged inadequate empirical justification for the axioms and neglect of the impact of 'disturbing causes' (using the British terminology) in application - Schumpeter's 'Ricardian Vice' no less but certainly not to deductive methodology as such: 
Peut-être est-on fondé à reprocher à M. Ricardo de raisonner quelquefois sur des principes abstraits auxquels il donne trop de généralité. Une fois placé dans une hypothèse qu'on ne peut attaquer parce qu'elle est fondée sur des observations non contestées, il pousse ses raisonnemens jusqu'à leurs dernières conséquences, sans comparer leurs résultats à ceux de l'expérience; semblable à un savant mécanicien qui, par des preuves irrécusables tirées de la nature du levier, démontrerait l'impossibilité des sauts que les danseurs exécutent journellement sur nos théâtres. Comment cela se fait-il? Le raisonnement marche en ligne droite; mais une force vitale, souvent inaperçue et toujours incalculable, fait dévier les faits loin de nos calculs. Dès lors rien dans le livre ne représente ce qui arrive réellement dans la nature.

$$
\text { (1819a, 1; lxiv-lxv; 1826a, 1: lxxxi-lxxxii) }
$$

'Il n'est pas prudent, en économie politique', Say cautioned in his Notes,

de s'étayer même du principe le mieux établi, pour en déduire constamment les conséquences les plus incontestables. Les résultats sont modifiés par une foule de circonstances dont l'influence n'est pas moins incontestable, et qu'il est on ne peut pas plus difficile d'apprécier. Heureusement que ces questions ardues ne sont pas celles dont l'application présente le plus d'utilité.

(1819b, 1: 419-20)

In elaborating, Say complained further of procedures that pretend to forecast what must necessarily occur, objectionable even if based on sound reasoning and 'certain' axioms as far as they go, when what was required is the explanation of events as they play themselves out by assigning them appropriately, in a sort of 'discovery' process, to the causes at play:

Il ne suffit pas de partir des faits: il faut se placer dedans, marcher avec eux, et comparer incessamment les conséquences que l'on tire avec les effets qu'on observe. L'Économie politique, pour être véritablement utile, ne doit pas enseigner, fût-ce par des raisonnemens justes, et en partant de prémisses certaines, ce qui doit nécessairement arriver; elle doit montrer comment ce qui arrive réellement est la conséquence d'un autre fait réel. Elle doit découvrir la chaîne qui les lie, et toujours constater par l'observation l'existence des deux points où la chaîne [1826a: des raisonnemens] se rattache.

(1819a, 1: lxv; 1826a, 1: lxxxii-lxxxiii)

On these grounds, Say objected in 1826 that McCulloch's recourse to 'exceptions' to the existing general 'system' in the wage-structure context was designed to insulate that system, though such counter-examples more often than not refute rather than confirm it: 
On s'écarte donc des notions de l'expérience la plus commune, quand on prétend qu'au moyen des compensations, les profits industriels sont les mêmes dans tous les cas. Rejeter dans les exceptions les exemples qui contrarient ce système, c'est détruire la loi qu'on veut établir; car ces exemples démentent plus souvent la loi qu'ils ne la confirment; la règle alors devient une exception.

$(1826 a, 2: 265)^{5}$

Elsewhere in the 1826 edition, in the same general context, Say pointed out that apparent 'exceptions', recourse to which is made by unnamed 'other economists', must be assigned to their proper 'causes' rather than left unaccounted for:

D'autres économistes qui soutiennent le même système quoique moins absolument, regardent comme des exceptions les phénomènes qui le contrarient; mais ces prétendues exceptions tiennent à des causes qu'il faudrait assigner. Si l'on rejette dans les exceptions les avantages qu'un producteur retire de la supériorité de son jugement, de son talent ou bien des circonstances plus ou moins favorables dans lesquelles agissent ses terres et ses capitaux, alors les exceptions l'emporteront sur la règle; celle-ci se trouvera contredite tantôt dans un point, tantôt dans un autre; ses hypothèses ne représenteront jamais un fait réel; elle ne sera jamais applicable; elle n'aura aucune utilité.

(173; emphasis added)

It is only by discovery of those causal influences, and the revelation of the 'general laws' at play, that scientific advance occurs, Say repeating a favourite theme:

L'économie politique n'est une science qu'en tant qu'elle fait connaître les lois générales qu'on observe dans l'économie des sociétés. Les lois générales sont l'expression commune qui convient à plusieurs faits particuliers; elles ne peuvent conséquemment être déduites que de l'observation des faits particuliers. Pour avancer la science, il faut donc voir des faits nouveaux ou mieux caractériser les faits connus; il faut rattacher des conséquences naturelles à des causes réelles, ou remonter d'un phénomène bien observé à une cause naturelle.

$(173-4 n$.

And he concludes pointedly: 'Mais ce n'est pas avancer la science que fonder un principe absolu sur un raisonnement abstrait. On peut disputer pendant des siècles sur de pareils principes, comme on l'a fait sur la grâce, sans établir une seule vérité.'

Say thus made out a case for responsible deductive methodology entailing a careful empirically based axiomatic foundation and avoidance of unexplained 
residuals. His bete noire was the Ricardian School; yet that his recommendations were actually in line with Ricardian methodological principle was even allowed by Say himself when in expansive mood (above, p. 38). The following statement by McCulloch, which extends to the dichotomy between political economy and 'statistics', confirms the near identity of his own and Sayian methodological principles:

Besides being confounded with politics, the practical part of Political Economy has frequently been confounded with Statistics; but they are still more easily separated and distinguished. The object of the statistician is to describe the condition of a particular country at a particular period; while the object of the political economist is to discover the causes which have brought it into that condition, and the means by which its wealth and riches may be indefinitely increased. He is to the statistician what the physical astronomer is to the mere observer. He takes the facts furnished by the researches of the statistician, and after comparing them with those furnished by historians and travellers, he applies himself to discover their relation. By a patient induction - by carefully observing the circumstances attending the operation of particular principles, he discovers the effects of which they are really productive, and how far they are liable to be modified by the operation of other principles. It is thus that the relation between rent and profit between profit and wages, and the various general laws which regulate and connect the apparently clashing, but really harmonious interests of every different order in society, have been discovered and established with all the certainty of demonstrative evidence.

(McCulloch 1825 [1823]: 49-50)

McCulloch's case against 'statistics', the insistance upon a careful establishment of the axiomatic base and proper allowance for disturbing causes are precisely what Say emphasized. It is of high interest indeed that the Cours complet should actually cite favourably McCulloch's defence of economic theory, specifically his contention that there were no uncertainties attached to the science of political economy:

On a dit que l'économie sociale présente des questions insolubles; que celle de l'utilité du luxe, par exemple, n'est pas encore résolue. Elle ne l'est pas en effet, mais c'est pour ceux qui n'ont pas assez étudié les premiers principes de la science. Quiconque s'est formé une idée complète du phénomène de la production, quiconque a analysé les effets des diverses sortes de consommations, sait fort bien ce qu'il doit penser du luxe. 'Le désir d'arriver d'un saut aux derniers résultats et aux conclusions pratiques de l'économie politique, a dit M. Macculloch, est l'erreur commune de ceux qui ne sont pas assez avancés dans cette étude' [1825b: 81]. Si la science présente des incertitudes, ce n’est donc pas à 
ceux qui l'étudient qu'il faut s'en prendre; mais à ceux qui ne l'étudient pas. Et ce qu'il y a de pis, c'est que ceux qui ne l'étudient pas sont les plus prompts à trancher les questions, et à donner des explications fort ridicules des phénomènes qu'ils reprochent aux autres de ne pas bien expliquer.

(Say 1843 [1828-9]: 18-19)

Also in line with Say's recommendations is J. S. Mill's appeal to retrodiction as a 'discovery' process designed to account for hitherto unexplained residuals, on the grounds that all apparent 'exceptions' or 'disturbing causes' are in fact themselves the outcome of causal laws that must be understood (Hollander and Peart 1999).

One is led to ask how much McCulloch and Mill might have based themselves directly on Say, considering the latter's temporal precedence. This is no fanciful conjecture. For Say, in his review of McCulloch's Discourse, did in fact charge $\mathrm{McCulloch}$ with plagiarism with respect to the foregoing issues:

Je passe par-dessus beaucoup d'autres considérations importantes, relativement à l'objet, aux moyens et à l'histoire de l'économie politique, considérations que les lecteurs français avaient déjà remarquées dans un autre discours préliminaire dont M. M'Culloch s'est servi beaucoup plus souvent qu'il ne l'a cité, pour arriver à des points en litige auxquels on a attaché quelqu'importance de l'autre côté du détroit, et sur lesquels l'opinion générale est encore loin d'être fixée.

(Say 1825: 697-8)

The specifics of the charge are spelled out by the 'Rédacteur principal' of the Revue Encyclopédique (see Appendix II).

Say made the case that the tendency to profit-rate uniformity was strongest in advanced economies such as Holland and Britain (above, p. 116). He was apparently unaware that Ricardo too gave an empirical justification for his behavioural and technological axioms (Ricardo 1951-73, 1: 99; 2: 340-1). (On this matter, see also J. S. Mill in Mill 1963-91 [1843], 8: 906.) There is too his objection to procedures allegedly pretending to forecast inevitable outcomes (above, p. 238). A specific instance of his own stance is the use of the growth analysis based on the population principle not as a predictive device but rather as a framework for policy to the end of preventing worst-case outcomes. Thus after tracing out in the Cours complet his pessimistic version of the canonical model, turning on diminishing returns even with allowance made for foreign trade (above, p. 125) - he proceeds to insist that precautionary measures were required since it would be irresponsible to presuppose continuous technical progress of sufficient magnitude:

Être capable de prévoir un malheur, est la première condition nécessaire pour le prévenir. Je crois que les progrès que l'industrie a faits presque 
partout, de notre temps, ont contribué à l'augmentation du nombre des hommes qui se remarque presque partout en Europe. Je crois que la multiplication des pommes de terre, de son côté, y a beaucoup contribué. S'ensuit-il que cette progression doive durer éternellement? Gardons-nous de le supposer.

(Say 1843 [1828-9]: 379)

It is specifically a Malthus-like appeal to prudential population control, though attributed to Sismondi, that Say had in mind:

M. de Sismondi en conclut que le principal obstacle à la multiplication des hommes est dans la volonté des hommes eux-mêmes. C'est ce qu'on ne lui dispute pas, pourvu qu'il convienne que cette volonté leur vient du défaut de moyens d'exister, ou seulement de la crainte d'en manquer; et alors ce sera toujours la borne des moyens d'exister, qui marquera la limite de la multiplication. Ce sera cette borne qui arrêtera les plus prudents; ce sera contre cette borne que viendront se briser les fous qui courent dans la carrière de la vie sans regarder devant eux. Nous sommes exposés, nous autres hommes, à beaucoup de maux par cette prévoyance qui nous rend malheureux de la crainte du mal.

Such precautionary behaviour did often prevent 'des fâcheuses extrémités où une multiplication inconsidérée précipite, dans les autres espèces, une multitude de créatures vivantes' (377). A brief statement regarding 'la vraie science' in 1826 summarizes conveniently the principle at stake: 'Elle ne donne pas de conseils; mais elle montre aux hommes les bonnes ou mauvaises conséquences de ce qu'ils font' (1826c: 42).

As we have pointed out at the outset of this study (above, p. 15), this sort of perspective on the role of theory is essentially canonical. It is, though, paradoxical, considering the set-piece roles attributed so often to the contrast between Say and the Ricardians on method, that the former's vision of a 'perfected' or 'completed' body of principles (above, p. 228) goes further than anything to be found in the British literature.

* * *

Let us now look at some of Say's actual procedures. How closely did he approach the ideal he laid out? This exercise will allow further comparisons with British procedure.

It will be recalled from his discussion of wage relativities (above, p. 239) that Say objected to the treatment of phenomena apparently conflicting with the propositions of an economic model - relatively high payments for scarce 'talent' or other favourable characteristics attached to land or capital - as 'exceptions' with no attempt made to account for them. He himself, so he 
there implied, by attending to new or newly-observed or newly-understood facts in the real world, constructed his theory on sound generalizations rather than on abstract reasoning: 'Rejeter dans les exceptions les exemples qui contrarient ce système [des compensations] c'est détruire la loi qu'on veut établir; car ces exemples démentent plus souvent la loi qu'ils ne la confirment.' But Say did not reject competitive wage-differential analysis, and did not follow through by devising a new model, or at least offer some new explanation for wage distortions. Here he fell short of J. S. Mill who also proposed model improvement in the light of verification and retrodiction to the same end of leaving no unexplained residuals, but put the advice into practice by incorporating into his model the notion of "non-competing groups' and explaining the skewed structure of wages in terms of the differential effects on particular categories of labour generated by aggregate unemployment (Hollander 1985: 304-15).

Moreover, despite his empirical objections, Say continued to allow the usefulness of the uniform profit-rate tendency at least in advanced economies such as England, a position shared with Ricardo and J. S. Mill. And in this context, notwithstanding his formal objection to the treatment of 'exceptions' by the British writers - their relegation of apparent exceptions to a class left unaccounted for - Say himself had recourse to 'disturbing causes', while insisting as always on the fruitfulness of generalization as expounded in treatises on the principles of political economy:

Il est impossible de suivre les variations des profits dans tous les cas particuliers; ils peuvent subir des variations extrêmes en raison d'une découverte importante, d'une invasion, d'un siège. L'influence de ces circonstances particulières se combine avec l'influence des causes générales, mais ne la détruit pas. Un traité, quelque volumineux qu'on le suppose, ne saurait prévoir tous les cas particuliers qui peuvent influer sur les valeurs des choses; mais il peut assigner les causes générales et celles dont l'action est constante; chacun peut ensuite, selon les cas qui se présentent, apprécier les modifications qui sont résultées ou qui doivent résulter des circonstances [1826a: des circonstances accidentelles].

(Say 1814, 2: 56; 1817, 2: 66; 1819a, 2:

$83 ; 1826$ a, 2: 248; emphasis added)

The same justification for a treatise concerned only with general principles, leaving to each reader the 'modifications' to be made in practical application, appears in the course of a contrast between the peculiar qualities required of, and the relatively high rewards earned by, commercial relative to agricultural entrepreneurship. The formulation in question would be at home in any 'Ricardian' text:

Ce n'est pas à dire que l'industrie commerciale, dans toutes ses branches, exige des qualités plus rares que l'industrie agricole. ... C'est au lecteur 
à faire les applications. Je cherche à poser des principes solides [1826: des principes]; on en peut ensuite tirer une foule de conséquences plus ou moins modifiées par des circonstances, qui sont elles-mêmes les conséquences d'autres principes établis dans d'autres parties de cet ouvrage. ... C'est à la personne qui veut faire l'application des lois générales à un cas déterminé, à tenir compte de l'influence de chacune de celles dont l'existence est reconnue.

(1814, 2: 77-8; 1817, 2: 86-7; 1819a, 2: 104-5; 1826a, 2: 274-5; emphasis added)

The assertion that the 'modifications' to be allowed for in each case were themselves the outcome of principles established elsewhere in the Traite is an exaggeration as is evident from mention of the variety of motives at play in the loan market which, Say insists, he could scarcely be expected to take into account in the Traité:

On n'exigera pas que j'essaie d'apprécier la force des motifs d'attachement, de parenté, de générosité, de reconnaissance, qui font quelquefois prêter un capital, ou influent sur l'intérêt qu'on en retire. Chaque lecteur doit évaluer lui-même l'influence des causes morales sur les faits économiques, les seuls qui puissent nous occuper ici.

(1814, 2: 111; 1817, 2: 121; 1819a, 2: 143; 1826a, 2: 321)

A further illustration of Say's 'classical' procedures may be drawn from the pricing context in the last two editions of the Traité, where he distinguishes between 'des causes générales et permanentes' playing on demand and supply, and others 'passagères et accidentelles, dont l'action se combine toujours plus ou moins avec l'action des causes générales' (1819a, 2: 15; 1826a, 2: 167). These 'exceptions' include the effect of expectations - scarcely one would think a matter to be relegated to secondary status:

Quand l'année s'annonce pour être bonne et fertile en vins, les vins des récoltes précédentes, et même avant qu'on ait pu livrer à la consommation une seule goutte de la récolte nouvelle, baissent de prix parce qu'ils sont plus offerts et moins demandés. Les marchands redoutent la concurrence des vins nouveaux, et se hâtent de mettre en vente. Les consommateurs, par la raison contraire, épuisent leurs provisions sans les renouveler, se flattant de les renouveler plus tard à moins de frais.

Apart from expectations, a whole range of motives are listed amongst the 'modifications':

L'espérance, la crainte, la malice, [1826: la mode,] l'envie d'obliger, toutes les passions et toutes les vertus, peuvent influer sur les prix qu'on donne ou qu'on reçoit. Ce n'est que par une estimation purement 
morale qu'on peut apprécier les perturbations qui en résultent dans les lois générales [1819: calculs positifs], les seuls qui nous occupent en ce moment.

(1819a, 2: 19; 1826a, 2: 168)

In the 1819 version Say seems to include natural monopoly as an 'exception', for he has a paragraph on the matter immediately following his relegation of expectations to that category:

Il y a aussi des monopoles voulus par la nature ou par les lois, qui empêchent perpétuellement de certaines choses d'être offertes au même degré que leurs analogues. Tels sont les vins de quelques crus privilégiés. Les services productifs de ces fonds de terre sont constamment moins offerts et plus demandés que d'autres. Le service de la poste aux lettres est de même dans presque tous les pays, à un prix-monopole.

This is omitted in 1826, perhaps reflecting a realization that the phenomenon belonged within the corpus of general principle.

Say goes further. In analysing the falling profit (interest) rate in terms of Smithian competition of capitals (above, p. 109), he represents the socalled 'exceptions' or countervailing forces - to the British colonial acquisitions after 1763 mentioned by Smith, he adds French experience in 1812 - as actually confirming the 'general law': 'Ces exceptions confirment la loi générale et permanente, qui veut que plus les capitaux disponibles sont abondans en proportion de l'étendue des emplois, et plus on voie baisser l'intérêt des capitaux prêtés' (1814, 2: 108; 1817, 2: 116-17; 1819a, 2: 138-9; 1826a, 2: 316). But nowhere is a means suggested of discerning when a general rule is to be abandoned or modified in the light of an apparent empirical refutation. We have even encountered a presumption that the influence of 'particular circumstances' combines with that of general causes 'mais ne la détruit pas' (above, p. 243).

We arrive at the same broad conclusions when account is taken of the Cours complet. Say himself there points out that certain of his own central accounts of pricing assume full service mobility between uses; it is only that this assumption does not hold good universally, considering such cases as special artistic talents or land peculiarly suitable for cultivation of a particular wine where the pattern of demand plays on factor prices and in this manner on costs (above, p. 95). Even so, Say insisted on 'la marche naturelle des choses' involving general tendencies disturbed by 'accidental causes', those general tendencies referring here to supply and demand, identified respectively with 'des frais de production' and 'des besoins des consommateurs':

C'est à cela, ce me semble, que se réduit la théorie de l'offre et de la demande des produits. Elle suffit pour expliquer la marche naturelle des choses, la manière dont elles se comportent, lorsqu'elles sont abandonnées 
à elles-mêmes; mais, au milieu des lois et des erreurs qui dominent la société, il arrive fort souvent que leur prix reçoit d'autres influences que celles qui naissent des frais de production et des besoins des consommateurs. Alors la cause accidentelle agit aussi longtemps qu'elle dure, et la loi générale reprend peu à peu son empire lorsqu'elle n'est plus contrariée.

(1843 [1828-9]: 171; emphasis added)

In fact, these accidental causes playing on quantities demanded and supplied 's'apprécient d'autant mieux que l'on a des idées plus justes sur les causes permanentes qui établissent l'offre et la demande en général' (172). He similarly refers to 'l'état naturel et ordinaire des choses' in the subsistence-wage context (334; see above, p. 128).

All this is in line with general British procedure. In any event, Say himself certainly did not reject the model based on the assumption of an 'entière liberté de disposer de nos capitaux et de nos talents' (329). He made much of his own methodological distinctiveness, but in the end he only insisted that the assumption does not cover 'toutes les causes' actually at play in particular real-world cases, as if this was not broadly appreciated:

Les écrivains qui font de l'économie politique abstraite, plutôt que de l'économie politique pratique, n'admettent aucune différence dans les profits qu'à égalité de talents, à égalité de capitaux, font les entrepreneurs d'industrie. Ils supposent les entrepreneurs toujours en liberté d'employer leurs moyens à l'industrie qui rapporte le plus; s'il y a quelque différence dans leurs profits, ils supposent qu'elle est contrebalancée par l'agrément ou le désagrément de la profession. Je suis loin de méconnaître cette cause de disparité dans les profits . . .; mais il me semble que l'entière liberté de disposer de nos capitaux et de nos talents, même dans les pays où les lois n'y mettent aucun obstacle, est une chimère. Peu de personnes choisissent librement l'état qu'elles embrassent. On est plus ou moins l'esclave des circonstances; il faut donc étudier ces circonstances lorsqu'on veut connâtre toutes les causes qui influent sur la distribution des richesses.

(329; emphasis added)

In fact, as in the Traité, Say did not restructure the broad vision of economic process in a market system in the manner of J. S. Mill's treatment of noncompeting groups and states of global disequilibrium (see above, p. 243); he insisted only on appropriate qualification in application. And since he actually predicts that obstacles to rapid adjustment would diminish over time with improvement in knowledge (in his 'third letter' to Malthus cited above, p. 208), the alleged differences with the British economists even regarding application are further reduced. 
Say comes close to a genuine reorientation of theoretical perspective when, anticipating J. S. Mill, he questions the 'Treasury View' reasoning to which Ricardo frequently appealed, and allows for aggregate-demand variation as a cause of output fluctuation (see above, pp. 202-3). And yet ironically it is precisely the chapter 'Des débouchés' of the Traité that, for Schumpeter, reveals Say to be 'an addict of the Ricardian Vice':

But Say himself was little interested in the analytic proposition per se which for us constitutes the merit of his chapter on débouchés. Like many other economists of all times, he was much more anxious to exploit it for practical purposes than to formulate it with care. He was an addict to the Ricardian Vice. . . The chapter, being mainly an argument for laissez-faire and against restrictions upon production, abounds in reckless statements, which were precisely the ones to attract attention. His readers were treated to a picture of the capitalist process that showed only a triumphant onward march of industry with nothing to disturb permanent advance at full employment except sectional maladjustments and restrictive government policies. All the other ills under which people groaned vanished before the battle cry, Supply creates its own Demand, which was made to mean much more than it can possibly mean when properly interpreted.

(Schumpeter 1954: 618)

This indictment cannot be sustained. As for the treatment of deviations from 'permanent advance at full employment', it is true that Say made appeal to disturbing causes - 'causes majeures', 'moyens violens', 'maladie politique' and restrictive policies; yet the notion of net demand for money to hold emerges clearly enough, if not as cause than as accompaniment of general depression, while the disquisitions regarding hoarding once deflationary expectations and uncertainty had set in are impressive indeed (above, pp. 193-4). Some of this is to be found outside the chapter 'Des débouchés' with which Schumpeter was formally concerned, but it is to leave a false impression not to have drawn on the fuller picture.

Also requiring notice are Say's qualifications to the laissez-faire implications of the Law of Markets. For Schumpeter's allegation in this respect is undermined by the case for government intervention in the event of technological unemployment, albeit that the depressing effects of 'machinery' on wages and employment were perceived to be localised and temporary (Baumol 1997: 221-3; 2003: 41-3). The Traité in 1814 and 1817 goes so far as to propose public works and state direction of new labour-saving techniques, at least initially, to specific regions:

Remarquons qu'une administration économe et bienveillante [1814: habile] trouve encore des moyens d'adoucir ce mal momentané et local. 
Elle peut restreindre, dans les commencemens, l'emploi d'une nouvelle machine à de certains cantons où les bras sont rares et réclamés par d'autres branches d'industrie. Elle peut préparer d'avance de l'emploi pour les bras inoccupés, en formant à ses propres frais des entreprises d'utilité publique, comme celle d'un canal, d'une route, d'un grand édifice. Elle peut enfin provoquer une colonisation, une translation de population d'un lieu dans un autre.

(Say 1814, 1: 55n.; 1817, 1: 55n.)

The proposal to direct the introduction of new machines is withdrawn in later editions as 'une violation de la propriété acquise par l'invention et l'exécution des machines', but for the rest there are no changes (1819a, 1: 56n.; 1826a, 1: 67n.).

On this broader view, Schumpeter's case against Say as 'addict' of the Ricardian Vice with respect to the Law of Markets is much weakened. Beyond this, in discussing the introduction of new technology in the Lettres à M. Malthus Say extends his admirable cautions regarding transitional problems quite generally:

What wise man would wish to abolish, all at once, the prohibitions which oppress industry, and the customs and duties which impede the intercourse of nations, prejudicial as they are to general prosperity? On these subjects, the duty of well-informed persons consists, not in suggesting motives for preventing and proscribing every species of change, under pretext of the inconveniences which it may produce; but in appreciating those inconveniences; in pointing out the practicable means of averting or mitigating them, in order to facilitate the adoption of a desirable amelioration.

(Say 1821 [1820]: 65)

In taking this sensible view, Say was wholly at one with Ricardo, considering the latter's concern with short-run friction in a variety of policy contexts, including money (above, pp. 8-9).

We have established Say's efforts to construct an engine of analysis - one might even dare to call it a 'system' - wholly in line with canonical procedure. The story in fact duplicates that of Malthus who formally objected to the 'speculations' of the 'new' Ricardian School, yet made out a strong case for deductive theory (see Hollander 1997: 949-68). In both instances the concern was to establish a proper empirical justification for the axiomatic base and assure responsible application, not to introduce an alternative 'inductive' method. 
Much has been made of Say's distinct conception of

the relations between political economy and modern society.... The particular colouring of Say's political economy comes from his emphasis on diffusing economic science in the social body, to the detriment of research bearing on some obscure point of theory,

a 'practical' perspective that 'explains Say's growing opposition to Ricardo's abstract method' (Steiner 1998c: 337-8). I am not convinced that the contrast should be expressed in quite this manner - Say, after all, composed five editions of the Traité and contributed, and impressively so, to fine points of theory as we have shown. Beyond this, his insistence on the role of general principles and the potential to achieve a 'complete' system outdoes anything found in Ricardo. Evidently, a 'practical' political economy had to be based on a firm foundation of economic theory, not drawn from the air. It is reassuring, we may add, that Steiner himself should proceed in his account to play down the contrast with the Ricardians, and for precisely the right reasons:

It is necessary, however, not to give this difference between Say and the English economists undue importance. In the first place, Say does not reproach them for being foreign to his own perspective but, rather, criticizes them for not having drawn out, as he himself has done, all the consequences of this aspect of the topic. In the second place, one must not believe that theoretical research is absent from Say's work: the Traité d'économie politique is there to prove the contrary, as Say's famous definition of political economy as the search for the laws of the production, distribution and consumption of wealth.

Similarly, while insisting on Say's hostility to Ricardo's 'abstract method' (Arena 2001a: 206, 210), Arena too allows that Say 'accepted the deductive interpretation of economics' provided it was properly based on axioms reflecting 'indisputable general facts' (208). This perspective is also implicit in what Arena writes regarding the broader question:

the distinction between a French and an English School is far [from] obvious, if we try to consider it seriously, namely from the point of view of economic methodology and analysis.... [I] $]$ spite of its imprecision, this distinction has been systematically utilized in the French literature, not so much to explain history of economic thought as it was, but rather to remold it in retrospect.

(Arena 2001b: 17) 


\section{Doctrine}

The Sayian doctrine of services corresponds to the canonical cost theory as Ricardo and Malthus insisted (above, pp. 59, 163); even Say did not invariably represent his position as paradigmatically opposed to the British view (above, p. 76). In any event, Say adopted the cost doctrine; and his continued adherence to it in the late 1820s is apparent from our investigation in Chapter 3. He insisted only on modifications once specialized factors are assumed, apparently unaware that here too he was restating British doctrine (above, pp. 6, 18). Say in fact worked explicitly with classical 'natural price' in the discussion of the effect on costs of technical change in the 1826 Traité (above, p. 90), though in the Cours complet he expressed a preference for the term 'prix originaire' or 'prix réel' since 'le prix courant, lorsqu'il s'établit de lui-même, n'est pas moins naturel' (Say 1843: 172n.). Potier maintains that by 1814 Say had abandoned Smith's distinction between 'valeur naturelle' and 'valeur échangeable' (Potier 2003: 289). In fact at most he had abandoned the terminology.

A letter to Tooke dated 8 January 1826 regarding the fifth edition of the Traité rejects costs but specifically as 'foundation' of price: 'Vous verrez, Monsieur, que je nie plus nettement que je n'avais encore fait, que les frais de production soient le fondement du prix des choses. Ils ne font pas naittre ce prix', Say proceeding to make heavy weather of the point that mere expenditure of outlays in the production of what can be obtained for nothing will not generate a price (Say 1848: 527). But this is not to deny a cost theory of value. We are in fact back to the letter to Ricardo of 10 September 1815: 'Je dis donc, comme vous que les frais de production d'une chose, déterminent la plus basse limite de son prix; mais ils ne sont pas la cause première du prix qu'on en offre', on which occasion Say had added: 'Il me semble qu'il n'y a rien là de contraire à ce que vous établissez' (above, p. 28). And that nothing had changed over the years is further confirmed by an informal reaction to a later objection by Auguste Walras for allegedly downplaying scarcity conditions, and representing utility as sole cause of value: 'ne fais-je pas entrer les frais de production comme un des fondemens de la valeur?' (cited in Potier 2003: 296). On these grounds, even Potier, who perceives a growing breach with Ricardo (above, p. 18), concedes that Say 'conserve toujours deux fers au feu et en refusant d'oublier complètement les frais de production, il reste un économiste classique de la tradition française' (297). But this is to put the matter too mildly. Thus a letter dated 15 April 1828 to Tooke, to whom Say sent a presentation copy of the first volume of the Cours complet, focuses entirely on costs in value formation:

Quant à la question du fondement de la valeur échangeable (que je regarde, avec Adam Smith, comme un caractère essentiel de la richesse sociale), je ne pense pas qu'on puisse la trouver dans la limitation de la quantité (limitation of supply); j'en donne les motifs très-développés dans l'ouvrage que j'ai l'honneur de vous offrir. On n'obtient gratuitement 
que ce qui peut être acquis sans frais de production; une chose a donc de la valeur, quelle que soit sa quantité, en proportion des frais que cette quantité coûte, pourvu que l'utilité que les hommes trouvent en elle soit suiffisante pour leur faire surmonter les difficultés (the cost of attainment) sans lesquelles elle n'existerait pas, c'est-à-dire les difficultés qu'il faut nécessairement vaincre pour lui donner l'existence.

(Say 1848: 535)

Though this statement is somewhat wanting regarding the role of scarcity in value formation - and might justify Schumpeter's strictures (above, p. 16) the insistence on the priority of supply places Say distinctly in the Ricardo camp.

We turn now to the Sayian entrepreneur. Consider the extracts from the Cours complet where Say treats the return to entrepreneurship as comprising 'un profit qui sera le salaire de son temps, de ses talents, de ses peines', the latter involving not only the function of catalyst linking the various markets for services and products but also that of risk taking (above, p. 113). Only if expected sales proceeds cover these costs of production would the entrepreneur undertake the exercise.

Though the function of catalyst was to be adopted by Walras (1954 [1874]: 222, 227), Walras himself complained that Say failed to provide a place for the entrepreneur in his theory:

J. B. Say had a tolerably clear and accurate idea of the combination of the three productive services in the process of production. The terminology he employed was good; we have therefore adopted it ourselves. But there were large gaps in his work which needed to be filled. In the first place, J. B. Say did not fully understand the specific role of the entrepreneur. In fact, this person is absent from his theory.

This is to take a very strict view indeed since it was surely a crucial first step to have proposed greater precision regarding the locus of decision making in the market process. It is nevertheless true that Say frequently reverts to the three-factor scheme, and that even when he explicitly has mediation by the entrepreneur in mind, he fails to expound adequately the nature of the demand for his services (above, pp. 115-16).

Walras pointed out more generally that Say 'did not give an adequate explanation of the services for which wages, interest charges and rent are paid; and he goes no further than the Physiocrats in showing how the prices of these services are determined' (426). I would say rather, on the basis of the evidence given in this book, that Say did not carry the analysis of pricing, whether of services or products, beyond the early nineteenth-century canonical writers, despite the 'services' terminology. This may be said to hold true of long-run cost-price analysis even when we take account of the riskbearing role attributed to the entrepreneur. 
Certainly Say himself placed his perspective on entrepreneurship at the forefront of his differences with the British classics, denying in the important review of McCulloch's Discourse that orthodox distribution analysis provided the key to an understanding of 'les vérités pratiques qui sont d'une grande utilité pour les particuliers', and insisting on uniformity of returns to capital apparently within and across industries and differential returns to entrepreneurship even in the same industry and even should the respective roles of capitalist and entrepreneur be undertaken by a single individual (see above, p. 113). This emphasis on practical usefulness is no mere flourish, as is indicated by the advice implicit in accounts of entrepreneurial behaviour in an uncertain world, such that only the 'prudent' entrepreneur can hope even to approach an accurate idea of his net worth at any time or make reasonable estimates in current decision making:

Comme il est difficile, et même peut-être impossible d'évaluer, avec une tolérable exactitude, les valeurs consommées et les valeurs produites, un particulier ne sait guère si sa fortune est augmentée ou diminuée, que par des inventaires de tout ce qu'il possède. Ceux qui ont de l'ordre en font régulièrement; et même les lois obligent les personnes qui sont dans le commerce à en faire tous les ans. Un entrepreneur ne sait pas, sans cela, si son entreprise n'absorbe pas plus de valeurs qu'elle n'en produit; il peut, dans cette ignorance [1814: sans le savoir], travailler à sa ruine et à celle de ses créanciers. Indépendamment des inventaires, un entrepreneur prudent compare d'avance les valeurs qu'absorberont ses opérations et la valeur probable de ses produits; ce sont des espèces de devis qui font présumer les résultats, mais ne les assurent [1814: déclarent] pas.

(Say 1814, 2: 191-2n.; 1817, 2: 201n.; 1819a, 2: 231n.; 1826, 3: 24-5n.)

By contrast, we have found that in theoretical contexts the emphasis is placed on 'risky' decision-making ability as a constraint on entrepreneurial supply, assuring a return to that function - a differential return and evidently in the long run considering that some suffer 'ruin' (above, p. 110). ${ }^{7}$ We are thus far from true 'uncertainty' in the Knightean or more recent 'Austrian' sense. In the Cours complet, Say insisted on this characteristic: 'On ne doit jamais perdre de vue qu'en économie politique le profit de l'entrepreneur fait partie des frais de production. Son travail est une avance qui doit être remboursée par la valeur de ses produits; autrement il est en perte' (1843: 409n.; also 549n.), where the term 'travail' is used in the broad sense of function rather than work literally. Say, it may be said, opened the door into a real world of uncertainty but did not cross the theoretical threshold, wedded as he was to a competitive equilibrium framework. Here mention should be made of Koolman's judicious conclusion regarding Say's treatment of the entrepreneur, especially his insistence on placing that treatment in proper historical perspective: 
Its central preoccupation was with the static role of the entrepreneur organizing resources necessary to satisfy market demands. There was no appreciaton of the entrepreneur acting on his environment; consequently the calculations in which the Sayian entrepreneur was likely to be involved were all in response to exogenous variables. It is not surprising, therefore, to find only limited mention of innovation, although in a number of places the analysis was extended to introduce the principle of economic change and the consequent elements of uncertainty. In retrospect it is right to emphasize these elements wherever they appear, though for Say, perhaps, at the time, they remained more in the nature of suggestions without the consequences being worked out. However, this would be to judge Say in terms of the results of an analysis which did not develop until nearly a century later. Judged by the standards of his own age, Say's ideas were highly sophisticated, and for a static analysis, completely adequate. Undoubtedly he had a marked effect on the development of thought of a number of English writers who adopted some of his terminology and his analytical approach to business units; and none of the neo-classical writers half-a-century later was to advance beyond the position he had developed.

(Koolman 1971: 286)

The analysis of entrepreneurship provides an instance of Sayian 'practical' political economy touching on allowances for short-term aggregate excess supply and is therefore of the highest relevance:

Lorsque les facultés industrielles propres à former un entrepreneur, sont trop abondantes sur le marché, elles s'offrent au rabais; c'est-à-dire qu'il s'y rencontre un trop grand nombre d'entrepreneurs en état, par leurs talents et leurs capitaux, de poursuivre avec succès le cours d'une entreprise. Dès lors les rétributions qu'ils peuvent obtenir par leurs capacités industrielles toutes seules, ne sont pas suffisantes pour les faire vivre selon l'état qu'exigent les habitudes du pays. Il faut dès lors qu'ils y joignent le profit d'un capital qui leur appartienne; car, s'ils font usage d'un capital emprunté, l'intérêt qu'ils sont forcés d'en payer les réduit à vivre sur leur industrie seulement, et celle-ci n'y suffit pas. Cette surabondance d'industrie, comparée avec les débouchés que laissent des institutions vicieuses [comme des monopoles tels que ceux des producteurs de blé, et des dépenses inutiles de la part du gouvernement], est je crois, une des causes qui ont souvent mis l'industrie anglaise dans la détresse. Le gérant d'une entreprise qui ne rapporte que cinq pour cent des fonds qu'on y emploie, s'il est obligé de payer quatre pour cent au préteur du capital, ne retire qu'un pour cent pour ses talents et son travail. Ce profit insuffisant l'excite à grossir sa production outre mesure, et à se procurer des capitaux fictifs [comme des escomptes d'effets 
de circulation dans les banques publiques] à défaut de capitaux réels; car un pour cent qui ne lui donne pas de quoi vivre sur cent mille francs, le lui donne sur un million. ${ }^{8}$

(Say 1843 [1828-9]: 331)

Say's questioning of basic Treasury View reasoning, reviewed in our discussion of method, places him close to - and indeed ahead of - John Stuart Mill (see above, p. 203). The role accorded the entrepreneur in the creation of new sales opportunities, recently said to distinguish Say's Law of Markets from the British version, we have shown relates rather to limitations of a developmental nature and not to market constraints in an advanced economy (above, p. 218). There are no doctrinal differences here, since for Ricardo too a powerful disposition towards leisure would impose a constraint on growth of output.

There is also common ground on other major doctrinal issues, though by no means mutual recognition of such identity. Thus as shown in Chapter 4 , Say's case for 'riches' as a value concept turns out to be in line with Ricardo's position on riches once it was understood that real income rather than stock valuation is at stake; and that the quantifiability of riches, so incessantly insisted on, did not apply to real income implied Say's effective adoption of Ricardo's non-measurable utility perspective (above, p. 150). Beyond this, the third book on 'Consumption' in the tripartite division of Say's Traité deals with the standard 'classical' theme of productive vs. unproductive consumption and their respective effects on capital accumulation and the generation of a disposable surplus (and also with 'public' consumption). Say's classical status in these respects has been confirmed in Chapter 4 (above, p. 170f.) where we saw that J. S. Mill makes friendly notice of his contribution to the central proposition relating to the source of aggregate labour demand in capital accumulation; his account of the process of accumulation, with labour shown to be engaged in 'unproductive' consumption, is surely one of the best in the literature. We recall too from this same context that the doctrine of services did not prevent Say from utilizing the analytical device of wage advances in the same manner as Mill.

\section{Say and the canonical growth model}

We extend our overview of doctrine by reference to the features we have found in Say's corpus relating to the land-based growth model. There are more than seems to have been imagined: (1) differential rent and the zerorent extensive margin (above, p. 119). (2) The subsistence-wage path based on the population mechanism (above, pp. 67, 106); and the falling real-wage path generating deceleration of population growth and ultimate stationariness (above, pp. 125-7). And (3) the functional relation between the interest rate and the rate of capital accumulation (above, p. 129). There are, however, several qualifications that require attention. 
First, the canonical writers maintained an analytical version of diminishing returns, West alone of the February 1815 quartet who formulated the 'law' adopting an empirical version (Hollander 1998b: 232-3). Say was closer to West than to the mainstream Ricardians by envisaging knowledge creation itself as subject to increasing limitation and by framing the law even with allowance made for free trade (above, p. 127). Secondly, as noted above, in Say's texts are to be found both the unsatisfactory pattern of growth at a constant real wage and the more logical 'canonical' pattern of declining real wages with the subsistence wage emerging in a state of stationariness. But in neither version does Say spell out the shared-incidence principle entailing labour's rising proportionate share in the falling marginal product, so central to the canonical view.

There is a related complexity turning on Say's acceptance in the 1819 Notes of the Ricardian falling profit rate with rising real-wage goods costs (above, pp. 64-5). What is the status of this proposition that certainly implies an application of the inverse profit-wage relation? There would be little more to say were it the case that the 1819 acceptance of the Ricardian case for a falling return on capital constituted a flash in the pan to be abandoned thereafter. But the matter is not so simply disposed of. First, there is the supplementary comment in the Lettres à $M$. Malthus relating falling real wages and the profit rate to rising corn prices (above, p. 66). But beyond this Say claimed in the relevant Note appreciation of the Ricardian argument dating back to early editions of the Traité. And this reading is supported by later claims in 1826 and 1828-9 that diminishing returns, differential rent and zero-rent land were all established throughout his work at an early date and were in fact to be found in the Wealth of Nations (above, pp. 119, 135-6). How seriously are we to take these claims regarding some of the central features of the canon?

There is promising material in an 1803 reference to the North American case, where ample land supply permits only a low rent but a relatively high return to both capital and to labour:

En second lieu, une petite épargne de valeur-revenu produit dans les pays nouveaux une grosse augmentation de valeur-capital, à cause de la grande valeur qu'a, dans de tels pays, un petit capital. Supposons que sur une terre de l'Amérique septentrionale, un cultivateur ait élevé des bestiaux; ce qui a excédé la consommation de sa maison, a été vendu médiocrement, c'est-à-dire a payé un assez bon salaire pour le très-petit travail de l'industrie qui les a élevés, mais peu de chose avec cela pour le revenu de la terre où ils ont été nourris; néanmoins si leur producteur a pu accumuler le prix des bestiaux, ou les bestiaux eux-mêmes, cette augmentation de capital, toute mince qu'elle est, a quelque prix dans un pays où les capitaux sont fort chers et leurs produits bien payés.

(Say 1803, 2: 188) 
The initial relatively high return to capital engenders rapid accumulation, but Say immediately takes up its prospective albeit slow downward trend:

Ainsi, pour continuer le même exemple, si nous supposons que les bestiaux accumulés, aient été employés à des défrichemens, ou bien à mettre en état des chemins pour aller au marché voisin, ou à la rivière la plus proche, ces dispositions rapporteront beaucoup comparativement au petit capital qui y a été consacré.

Dans de tels pays les capitaux croissent vite; néanmoins il se passe beaucoup de tems avant qu'ils soient abondans, car ces pays dans leurs progrès rapides, en absorbent considérablement soit sous la forme de capitaux engagés, soit sous celle de capitaux circulans.

As for the wage rate, that remains unchanged - at least for a time - encouraging rapid population growth:

Toutefois quand leurs profits viennent à baisser, ceux de l'industrie se soutiennent encore; car les profits des capitaux ne peuvent baisser sans qu'il y ait une plus grande quantité de capitaux jetée dans la circulation; et cette circonstance même est un appel fait aux qualités industrielles. Faut-il être étonné si en Amérique, et dans tous les pays neufs où il y a un peu d'esprit de conduite, l'accroissement de la population soit si rapide? Elle est toujours excitée par l'ardeur productive des terres, et ne tarde pas à l'être par celle des capitaux.

There are certainly features of the land-based growth model here, all to be found in the Wealth of Nations (see for example Smith 1937 [1776]: 359, 548-9), Say's source as he frankly acknowledged. The Smithian elements are supplemented by the discussions in both the late Traité and the Cours complet of the falling real-wage path and ultimate stationariness, elaborations that might reflect the influence of the Ricardians. And yet it remains true that Say does not, in any of these contexts involving land-scarcity conditions, specifically relate the falling profit rate to rising real wage-goods costs. Indeed, Say insisted in the Traité that the high prices of 'necessairies', due for example to corn laws, raise general prices (Say 1817, 1: 262; 1819a, 1: 282; 1826a, 1: 334-5) - rather than lower profits - again a Smithian perspective. The claim of 1819 thus goes too far.

Of high interest indeed is Say's rejection in 1826 of the inverse relation when referring to McCulloch's evidence before a Parliamentary Inquiry of 1824:

M. Macculloch, à qui l'économie politique a d'ailleurs de véritables obligations, consulté, en 1824, dans une enquête parlementaire [McCulloch 1824], a soutenu que les profits des maîtres manufacturiers étaient 
d'autant moindres que les salaires des ouvriers étaient plus élevés, et vice versâ; tandis qu'il est de fait, au contraire, que les salaires ne sont jamais plus bas que lorsque les maîtres ne gagnent rien.

(1826a, 1: xxxvn.)

This complaint may be justified even on 'Ricardian' terms, since the inverse relation assumes full employment and cannot be applied to economies in depression. But Say probably did not have this in mind by his complaint, and simply failed to appreciate that the theorem relates to proportionate not absolute wages, and as such is wholly consistent with simultaneous increases, or decreases, in the returns to labour and capital.

What has just been said applies also to Say's appeal to 'experience' against the Ricardian inverse wage-profit relation in his review of McCulloch's Discourse:

L'expérience dément pareillement cette autre assertion de la même école, que les salaires de l'ouvrier et les profits de l'entrepreneur sont perpétuellement en opposition; que les salaires ne sauraient hausser, sans que les profits baissent, et vice versâ. Quiconque a vu beaucoup d'entreprises industrielles peut rendre témoignage que c'est dans celles qui donnent les plus gros bénéfices à leurs auteurs, que les ouvriers sont le mieux payés.

(Say 1825: 710)

And what follows immediately in the text provides a further instance of the fact that Say failed to appreciate the canonical position whereby an increase in the corn price depresses both the wage and profit rates, or the sharedincidence principle:

L'expérience dément encore une autre assertion de la même école. Ricardo a dit qu'en même tems que le prix de la main-d'oeuvre règle la valeur des produits, c'est le prix des denrées de première nécessité (des grains en Europe, par exemple), qui règle le taux de la main-d'oeuvre, et que le renchérissement du blé diminue le taux des profits et augmente les salaires. Or, je tiens des principaux manufacturiers d'Angleterre et de France, notamment de MM. Ternaux et fils, qui ont des manufactures à Liége, à Louviers, à Sedan, à Reims et à Paris, que c'est précisément le contraire qui arrive. Quand les grains deviennent plus chers, les salaires baissent. Ce résultat n'est point accidentel; la même cause est toujours suivie du même effet, et l'effet dure aussi long-tems que la cause. L'explication n'en est pas difficile: quand le blé est à un prix élevé, les classes laborieuses sont obligées de consacrer à leur dépense en blé une portion de leurs gains qu'elles auraient employée en vêtemens meilleurs ou plus recherchés, en logement, en meubles, en alimens plus succulens et plus variés; en un mot, elles réduisent toutes leurs consommations; 
et le défaut de consommation réduit la quantité demandée de presque tous les produits. Or, la réduction de la demande entraîne la médiocrité des profits de tout genre, aussi bien ceux des maîtres que ceux des ouvriers.

Without realizing it, Say was expounding the undiluted canonical view that real wages fall as corn prices rise.

\section{Internal paradigmatic conflicts}

The allowance in the Cours for increases in particular returns independently of each other and complex relations involving all three general returns point away from the inverse relation, and this despite recognition elsewhere of the zero-rent phenomenon:

Maintenant nous examinerons les causes qui tendent à grossir et à diminuer les revenus de certains producteurs indépendamment des autres, et même aux dépens des autres; des propriétaires de facultés industrielles, par exemple, à l'exclusion des capitalistes et des propriétaires fonciers; ou bien des capitalistes à l'exclusion des industrieux et des propriétaires; ou bien enfin des propriétaires fonciers à l'exclusion des capitalistes et des industrieux.

(Say 1843 [1828-9]: 323-4)

Moreover, despite the range of canonical features found in Say's work including the falling real-wage path and stationary state, the case for a falling profit rate due to rising costs of wage goods is to be found only in the Note of 1819 discussed above, supplemented by the more general comment in the Lettres à $M$. Malthus relating the falling profit rate to increase in the cornmanufacturing price ratio. These instances cannot be ignored. Yet it is certainly Smithian competition of capitals on which Say relied for the most part to account for the falling return on capital. Thus the 1803 account went on to cite Smith's countervailing upward pressure on profits exerted by the opening of new markets following the peace of 1763 , which is unrelated to land-scarcity conditions:

Smith a remarqué qu'après la paix de 1763 , l'intérêt de l'argent éprouva en Angleterre une hausse très-sensible (Wealth of Nations, Liv. 1, ch. 9). Les acquisitions importantes que l'Angleterre venait de faire ouvraient de nouveaux canaux au commerce et invitaient à de nouvelles spéculations: les capitaux jusqu'alors employés, ne furent plus suffisans: la demande des capitaux devint plus forte sans que les capitaux devinssent plus rares. La hausse de l'intérêt, qui est en général un signe d'appauvrissement, fut dans ce cas-ci, occasionnée par l'ouverture d'une nouvelle 
source de richesses, qui dut faciliter de nouvelles accumulations, et rétablir en peu de tems l'offre des capitaux au même point relativement à la demande.

(Say 1803, 2: 191)

In 1814 (and in later editions) Say again refers to Smith's illustration, adding French experience in 1812 as a second example of an 'exception proving the rule' that the return on capital falls merely by dint of accumulation (above, p. 245).

Say's recourse to Smithian doctrine in this instance is only one example of the presence of inconsistent elements in his work. For the very same Note accepting the Ricardian logic for the falling profit rate admits the error inherent in the notion of increasing competition of capitals as rationale that it conflicted with the Law of Markets as a secular proposition (above, pp. 64-5). Yet this admission is forgotten and the Smithian alternative to the Ricardian analysis - despite the commendation in the Note - is relied on till the very end (above, pp. 128-9). We must face the fact that Say's work is burdened by paradigmatic conflict some of which he recognized but failed to clear away systematically.

Also striking as an instance of paradigmatic conflict is Say's Smithian contrast between corn and other prices, the former characterized by the interdependence of demand and supply (above, p. 43). Now Ricardo insisted on applying to corn the same allocative analysis relevant to all products, based on demand - or rather expected demand - conditions independent of supply conditions; but Say did not hear the message and never abandoned the population-based argument (above, pp. 44-6). It is strange indeed that Say should not have realized that this perspective conflicted with his own insistence, against Ricardo's alleged view to the contrary, that it was prior expansion of demand for corn - not the existence of poorer land as such that was the 'cause' of rent (above, p. 131).

There is too Say's classification of agriculture as most productive sector (above, p. 54), and this despite his representing rent at times as a reflection of land scarcity. (It is Ricardo again who gave lessons in elementary price theory to correct Malthus's version of this same error.) This perspective reflects Say's subscription to Smithian investment priorities, where the divergence from the principle of social advantage deriving from private choice is serious:

L'emploi de capital le plus avantageux pour le capitaliste est celui qui, à sûreté égale, lui rapporte le plus gros profit [1819, 1826: intérêt]; mais cet emploi peut ne pas être le plus avantageux pour la société: car le capital a cette propriété, non-seulement d'avoir des revenus qui lui sont propres, mais d'être un moyen pour les terres et pour l'industrie de s'en créer un. Cela restreint le principe que ce qui est plus productif pour le particulier, l'est aussi pour la société.

(1814, 2: 119; 1817, 2: 130; 1819a, 2: 155; 1826a, 2: 340) 
Say goes on to assert - silently following Smith (1937 [1776]: 159) - that, happily, 'la pente naturelle des choses entrâne les capitaux préférablement, non là où ils feraient les plus gros profits, mais où leur action est le plus profitable à la société' (Say 1814, 2: 122; 1817, 2: 133; 1819a, 2: 158; 1826a, 2: 343).

Now Ricardo in his Principles objected that Smith, by his classification, 'constantly magnifies the advantages which a country derives from a large gross, rather than a large net income', and he extended the same objection to Say (Ricardo 1951-73, 1: 347). And regarding the latter's reliance on the happy circumstance that the 'natural' course of events tended to an appropriate investment pattern, he complained:

M. Say has not told us what those employments are, which, while they are the most profitable to the individual, are not the most profitable to the State. If countries with limited capitals, but with abundance of fertile land, do not early engage in foreign trade, the reason is, because it is less profitable to individuals, and therefore also less profitable to the State.

(349-50n.)

To this Say merely responded in his Notes by referring back to the classification itself:

Ce que M. Ricardo se plaint de ne pas trouver dans mon ouvrage, y est dans un passage que lui-même a cité quatre pages plus haut. Les emplois de capitaux, qui, tout en procurant un profit au propriétaire du capital, mettent en valeur les facultés industrielles des gens du pays, ou les facultés productives du sol, augmentent plus les revenus du pays, que les emplois qui ne procurent d'autre revenu que le simple profit du capital.

(Say 1819b, 2: 226)

The rationale I once offered in Smith's case to minimize the apparent conflict between this view and the principle of the social advantage assured by private choice (Hollander 1992: 170-5) would be inapplicable in that of Say.

There is a final matter, relating to foreign trade. Say had originally maintained the Smithian vent-for-surplus case for trade: 'C'est quand on ne peut plus produire aucun objet d'échange, que l'exportation devient avantageuse' (Say 1803, 1: 154). This statement from the chapter 'Des débouchés' no longer appears in later editions of the Traité; and the Commentary on Storch firmly rejects the doctrine:

On a beaucoup répété que le commerce extérieur consiste à échanger son superflu contre le superflu d'un autre people. Le fait est qu'aucun peuple n'a de superflu; car il n'en est aucun qui soit assez insensé pour produire 
des choses dont il n'a pas besoin. Qu'est-ce donc que ce prétendu superflu que l'on envoie à l'etranger? Ce sont des produits que l'on travaille, que l'on crée dans le dessein de les exporter.

(Say 1848 [1823]: 328)

He did not, however, convert from Smithian absolute-advantage to Ricardian comparative-advantage lines in arguing the efficiency case for free trade:

Une nation, sans introduire dans ses procédés de nouveaux perfectionnements, peut continuer toujours à échanger avec les mêmes profits ses produits contre ceux de l'étranger. Si, avec le produit de deux journées de travail appliquées à des ouvrages de quincaillerie, l'Angleterre peut acheter en Russie une quantité de chanvre qu'elle ne pourrait obtenir chez elle à moins de trois journées de travail, il lui convient d'acheter perpétuellement le chanvre de la Russie; et, de son côté, si la Russie, avec une quantité de chanvre qui lui coûte deux journées, peut acheter en Angleterre, une quantité de quincaillerie qu'elle ne pourrait produire elle-même à moins d'y consacrer trois journées, il lui convient d'acheter à perpétuité des quincailleries à l'Angleterre. 


\section{Conclusion}

\section{The impression of systemic discord}

Clearly there are doctrinal differences between Say and Ricardo and these we have summarized in the previous chapter. But there remains so much common ground - especially regarding value analysis but extending to major aspects of growth analysis - that the question arises: whence the impression obtained by so many commentators of systemic discord, allowing little if any place for the features held in common? This matter we shall address now, leaving till the next section a discussion of Say's increasing hostility towards the Ricardians, especially after Ricardo's death.

It seems evident that Say's retention of those Smithian structures reviewed in the previous chapter, must have clouded the extent of his actual adherence to the canon. Beyond this it is helpful to make allowance for the white noise disturbing the atmosphere and leaving an impression of discord where none exists.

Conspicuous here is the purely definitional dimension, a letter from Ricardo to Say dated 11 January 1820, touching on this matter:

I remember you remarked when I had the satisfaction of seeing you in Paris, that we should in every edition of our respective works approach more nearly to each others opinions, and I am persuaded the truth of this remark will be verified. We have already advanced some steps, and in proportion as we become better acquainted with the points of difference between use, we shall discover that many of them are merely verbal.

(Ricardo 1951-73, 8: 149; emphasis added)

A striking instance is Say's dislike of the term 'natural price' which easily leaves readers with a false impression of opposition towards substance (above, p. 90). There are also 'expositional' complexities, whether for example differential rent should be ascribed to the existence of a scale of land of differential productivity or to the pressure of demand, as if the two do not amount to the same thing (above, p. 131). To these complications may be added the confusion between utility as source of value and as determinant 
(above, pp. 28, 81, 97); and also the entanglement of 'value' and 'riches' - of positive and normative economics - and the frequent silent transfer between the two (Chapter 4, passim). Once the two are disentangled there emerges a concordance not only on the primacy of supply in value determination but also on riches as a flow of real income.

But the problem is compounded. Say recognized both the role of demand in the canonical growth system - not only in Ricardo's but in McCulloch's version (above, p. 139) - and the role of land scarcity in his own (above, p. 255). And he restructured the 1819 Traité to focus on a cost approach to relative price determination as Prinsep noted (above, p. 57). Unfortunately, he did not make his concessions in either a frank or consistent manner. Schumpeter has pointed out that Say invariably mismanaged his case in controversy by replying to criticism in a desultory manner, without bestowing the requisite amount of work on it' (Schumpeter 1954: 491). I would go a step further. As may have been the case with Malthus (Waterman 1991: 147), Say does not seem to have been a fair opponent in retreat so that a reader might easily bypass his concessions. For one thing, modifications were sometimes introduced without attribution of their source. Thus the abandonment of the alleged contrast between the gains from domestic and foreign trade, to which Ricardo objected, is made silently by way of a subtle textual amendment (above, p. 185). But beyond this, concessions are often surrounded by a litany of complaints of the old order.

We illustrate from the debate regarding 'riches', where Say misled readers by repeating his complaints against those who perceived 'riches' in nonmeasurable utility terms, though this is his own position in the real-income context; thus the claim to quantification is reiterated in the last edition of the Traité and in the Cours complet as if nothing had been resolved (above, pp. 161, 163). Similarly with respect to the profit-rate trend. Say admitted in the 1819 Notes that his Smithian doctrine of increasing competition of capitals was inconsistent with the Law of Markets interpreted in secular terms; yet the 1826 version of the Traité and the Cours complet allow back competition of capitals as if nothing had happened (above, pp. 128-9).

There are also the continued misreadings that contribute to an impression of severe discord even when none exists. Thus 'limits to production' - which conspicuously include land and labour scarcity - are represented as if they were foreign to the British 'speculative' or 'abstract' writers - Ricardo, James Mill and McCulloch - who allegedly ruled them out on grounds of the 'identity' version of the Law of Markets (above, p. 213). That this is a travesty of Ricardo's position is obviously true of the land-scarcity constraint. Backward technology is of this same order. But the labour-supply constraint reflecting a desire for leisure is also allowed for by Ricardo as, for example, in a comment on New Spain in the Notes on Malthus's Principles (Ricardo 1951-73, 2: 338). This is amply confirmed in those same Notes where Ricardo pointed out that even were the assumption of insatiability 
of human wants empirically invalid, the orthodox case that there can be no long-run deficiency of aggregate demand would remain firm: 'Men will prefer indolence to luxuries! Luxuries will not then be produced. ... If not produced they cannot want a market, there can be no glut of them' (315). This is Say's position precisely. Now Ricardo's formulation, Chipman maintained, 'takes much of the punch out of Say's Law; supply creates its own demand, yes, - provided, of course, that not more is supplied than will be demanded' (Chipman 1965: 712). Perhaps so, but the fact remains that the labour-scarcity constraint - as understood by both Say and Ricardo - is wholly consistent with the Law of Markets.

A further prime instance of 'misunderstanding' relates to the negative effect of taxation on economic activity, Say taking Ricardo to task for its neglect; it would even seem that in 1826 he sharpened the complaints, though it is patently clear that Ricardo was no friend of taxation (above, p. 182). We recall too Say's implication that the savings-interest relation was his alone, whereas it is of course a key element in the canonical structure (above, p. 129). Other instances will be found in the concluding section of Chapter 3 .

We turn next to policy, recalling J. S. Mill's observation that the principles of political economy adopted by Say and the British writers 'are not materially different in their practical result' (above, p. 226). Say himself said as much in the 'riches' context (above, p. 159). And indeed he supported Ricardo's freetrade policy as early as 1815 in the letter of 10 September (see above, p. 227). Years later in the Cours complet, we have a restatement of the free-trade case with reference to efficiency and minimization of a potential security problem:

On s'oppose à un perfectionnement de l'industrie et à la richesse des Anglais, en opposant des prohibitions ou des droits qui équivalent à des prohibitions, à la libre circulation des grains. Je ne discute point ici les raisons politiques qui pourraient balancer les avantages économiques de l'importation. Il se peut qu'il soit plus expédient pour un pays de payer le blé plus cher et de le produire sur son territoire, quoique je sois tenté de croire, avec Ricardo, qu'on n'en manque jamais lorsqu'on peut le payer, et qu'on ne peut jamais payer plus facilement que lorsque l'on achète au meilleur marché.

(Say 1843 [1828-9]: 357)

So far so good. But even in the trade context, Say may be shown to have misled. Thus a Note of 1819 takes a Ricardian line, though no reader would guess it. For Say sets out by following Buchanan allegedly against Ricardo on the principle that value is a 'relative' concept, to explain how it was that the price of corn had risen secularly in Britain:

M. Buchanan d'Édimbourg, le dernier éditeur de Smith, et l'un de ses plus dignes interprètes, me parât avoir ici raison contre M. Ricardo. Il établit que rareté et cherté sont une seule et même chose; je le pense 
comme lui. Rareté en matière de valeurs, ne se prend pas, ne peut pas se prendre dans un sens absolu, mais dans un sens relatif à la demande. Ainsi, quoique l'Angleterre produise plus de grains au dix-neuvième siècle que dans aucun des siècles qui ont précédé, je dis que le blé abonde moins en Angleterre qu'il ne faisait, et que sa quantité n'a pas augmenté autant que le nombre de ses consommateurs. ${ }^{1}$

(Say 1819b, 1: 372-3)

If all this is not pure Ricardo it is nothing. And the application to trade policy can certainly be found in any Ricardian text:

Cette législation est nécessitée par la circonstance qu'il y a en Angleterre, dans la réalité, deux prix naturels pour le blé. L’un se compose des frais de production du blé produit par les fonds de terre du pays; l'autre, des frais de production du blé produit par l'industrie commerciale, du blé que l'Angleterre doit à son commerce. Ce dernier prix est, en général, plus bas que l'autre; et si le gouvernment n'ordonnait pas qu'il ne sera versé du blé du commerce qu'autant que le prix s'en élevera à 80 sh., les cultivateurs ne pourraient soutenir la concurrence des négocians; ils ne vendraient pas un quarter de grain ce que ce quarter leur coûte; ils abandonneraient cette culture, au moins en partie, en acquitteraient difficilement leurs contributions, leurs fermages et la taxe des pauvres.

At the same time, Say did not accord this Ricardian perspective a conspicuous place in the Traité itself when discussing the post-war corn laws. The principle reason there given for the relatively high agricultural cost structure in Britain is heavy taxation with no mention of productivity conditions:

En 1815, l'Angleterre a redouté d'en voir trop baisser le prix par l'introduction des grains étrangers. La production des grains, comme toute autre production est beaucoup plus dispendieuse chez les Anglais que chez leurs voisins. Cela dépend de plusieurs causes qu'il est inutile d'examiner ici, et principalement de l'énormité des impôts.

$(1817,1: 261-2 ; 1819 a, 1: 281 ; 1826 a, 1: 334)^{2}$

Ricardo's underplaying in the Essay on Profits of the security concerns insisted on by Malthus - that 'l'Angleterre devenant un pays régulièrement et constamment importeur de blé, plusieurs contrées du monde prendraient l'habitude de lui en vendre' - is noted, and so too is his position that a free corn trade would reduce the danger of shortages ('des disettes') (1817, 1: 263-4; 1819a, 1: 283; 1826a, 1: 336). But there is no mention of high corn costs due to diminishing returns. An added passage in 1826 points to national debt and other 'charges' raising the British cost structure, but once 
again makes no mention of agricultural productivity conditions: 'Si les charges de l'Angleterre étaient moins lourdes, le blé pourrait y être produit à des prix plus rapprochés des blés étrangers; la libre importation de ceux-ci pourrait être permise, au grand soulagement des classes manufacturières' (1826a, 2: 77n.). The same stance will be found in Say's analysis of contemporary depression (1826c: 44). And at one juncture Say plays down somewhat the quantitative significance of corn in the working-class budget (see note 2), though this does not fit in well with his standard insistance on a firm corn-supply-population relation. Thus while Say recognized, even insisted upon, features of the land-scarcity model, and on occasion made use of it in policy application, he did not adopt it wholeheartedly as a tool in the interpretation of current events, making it easier for readers to overlook the common ground.

An additional contributing factor is Say's ascription of key features of the canonical growth model to Smith (above, p. 255), which helps us appreciate his opposition to claims made on Ricardo's behalf by McCulloch. That Ricardo himself was unaware of the full extent of the substantive agreement - his letter to Say of 8 May 1821 comments on the inadequate discussion of the laws regulating rent and profits, or of population and land scarcity (Ricardo 1951-73, 8: 380) - should therefore come as no surprise.

Finally, Say's methodological pronouncements which increasingly complain about Ricardian procedures can only have left an impression of deep discord. It is scarcely surprising that readers ever since have been unaware that some of the strongest arguments for deductive theory are formulated by Say himself.

\section{Say's increasing hostility}

There remains to consider the notion of increasing hostility on Say's part towards Ricardo with the passage of time, reflected in Steiner's numerical count of a rising 'negative to positive' ratio in Say's references to Ricardo (above, p. 18). There are of course problems with quantitative exercises. When, for example, Say insists that Ricardo has no priority on the matter of differential rent, is this to be counted as a 'positive' or a 'negative' reference? When Say contends erroneously that Ricardo neglected the endogenous cost margin in agriculture and mining, or when he writes critically of the exclusion of rent from cost yet goes on to recognize the phenomenon of zero-rent land, or yet more conspicuously when he objects to Ricardo's cost theory of value only to adopt it himself, how are we to make the classification? But there is no need to be held up by such problems, since I believe Steiner to be correct. There is indeed evidence of growing hostility towards Ricardo, and a fortiori towards the Ricardians, after his death.

A non-quantitative index of the change in mood is provided by taking for comparison the correspondence of 1821, particularly the important letter of 19 July where Say expressed nothing but goodwill towards Ricardo upon 
receipt of the third edition of the Principles, while at the same time not disguising the existence of their differences:

J'y vois de nouvelles preuves que les matières d'Economie politique sont prodigieusement compliquées, puisque, tout en cherchant la verité de bonne foi, et après que nous avons, les uns et les autres, consacré des années entières à approfondir les questions que présente cette science, il est encore plusieurs points sur lesquels M. Malthus, vous, et moi ne pouvons entièrement nous mettre d'accord.

(Say, in Ricardo 1951-73, 9: 31)

This is a mirror image of the friendly manner in which the exchange was conducted on Ricardo's side: 'You, I know, always exert yourself in the good cause, and have no other object in view but the diffusion of knowledge, and the triumph of truth' (8 May 1821; Ricardo 1951-73, 8: 381). A letter from Ricardo to Trower dated 23 August 1817 reveals that Say's praise in the Traité of Ricardo's contribution to money (1817, 2: 29n.) - it was removed in 1826 (see below, p. 270) - caught his attention; and while Ricardo remarked on the difficulty Say found in comprehending his Principles unrelieved as it was by 'a few occasional examples, and illustrations', he also conveyed to Trower that Say who he had visited in Paris 'was very friendly and agreeable - spoke favourably of my book - was quite sure that in a very few years there would not be a shadow of difference between us' (Ricardo 1951-73, 7: 178).

Contrast these indications of mutual goodwill with a report by Sismondi to a correspondent in September 1826:

I had this morning a visit from Say, who said to me that his friendship for M. Ricardo, and his school, has very often cramped him, but that in truth he finds that they have injured the science by the abstractions into which they have thrown it, and that he shall be obliged, in the new edition [of the Traité] he is preparing, absolutely to oppose them.

(Sismondi 1847: 449)

If this report is to be believed - and there is independent evidence that it can be (see below, pp. 272-3) - Say had hitherto pulled his punches out of 'friendship' and no longer intended to do so.

Increasing hostility is particularly conspicuous in the methodology context. We recall first Say's strongly expressed case favouring deductive methodology directed not only against inductivists or practitioners of 'political arithmetic' but equally against Ricardo. Here Say wrote much in the manner of Sismondi (1951 [1827], 1: 69-70) and Malthus (1820: 308-9; 1986 [1824] 7: 297), who both objected to Ricardo's alleged irresponsible theorizing and applications. Now the 'Discours préliminaire' to the last edition of the Traité contains an added indictment of the 'scolasticism' 
attributed to 'l'école dogmatique de Quesnay d'une part, et des économistes anglais de l'école de David Ricardo', who, without using algebraic formulae which were 'trop évidemment inapplicables à l'économie politique', nevertheless adopted the illegitimate method of 'argumentation' based on 'abstraction' rather than 'experience' (Say 1826a, 1: xxxiii). Here Say refers to Condillac's 'judicious' remark that 'un raisonnement abstrait n'est qu'un calcul avec d'autres signes', ${ }^{3}$ and proceeds in harsh tones indeed:

La meilleure dialectique aussi bien que le calcul le plus exact, s'ils partent d'une donnée incertaine, arrivent à des résultats douteux. Quand on admet pour fondement, au lieu d'un fait bien observé, un principe qui n'est fondé lui-même que sur une argumentation, on risque d'imiter les scolastiques du Moyen Age, qui discutaient sur des mots, au lieu de discuter sur des choses, et qui prouvaient tout, hors la vérité.

(xxxiv)

The defective practice is illustrated by Ricardo's exclusion of rent from cost price:

Il est impossible de se dissimuler que Ricardo a fondé un principe sur une argumentation, lorsqu'il a dit que le revenu des propriétaires fonciers ne fait pas partie du prix des choses. De ce principe il tire plusieurs conséquences; de ces conséquences il en tire d'autres, comme si elles étaient des faits constans; tellement que si, comme il est permis de le croire, la première donnée n'est pas exacte, tous les raisonnemens dont elle est la base, en les supposant irréprochables, ne peuvent conduire à une instruction véritable. Dans le fait, les résultats obtenus par l'auteur anglais sont fréquemment démentis par l'expérience.

$($ xxxiv-xxxv)

At this point Say illustrates further from McCulloch's 1824 evidence based on the inverse wage-profit relation (above, p. 256). The same illustration is repeated in the Cours complet in the course of an onslaught against 'Ricardo and his school', of particular importance since it also rehearses the outdated charges that the Ricardians rejected demand-supply analysis and reduced costs to labour alone, thereby adding to the evidence of a concerted campaign on Say's part:

Une dialectique irréprochable et qui part de principes avoués, peut égarer même son auteur, lorsqu'il pousse trop loin ses inductions et qu'il ne les compare pas avec les résultats que nous offre le spectacle du monde réel. C'est un principe avoué que quiconque a la libre disposition d'un capital, le place en général dans l'emploi qui donne les plus gros profits; mais David Ricardo et son école en tirent des conclusions que l'expérience dément perpétuellement. Ils méconnaissent tous autres frais 
de production que ceux qui naissent du travail de l'homme; ils méconnaissent l'influence de l'offre et de la demande, renvoyant dans les exceptions les autres causes qui font varier les prix; or, les cas d'exception sont plus nombreux que les cas qui arrivent conformément à la règle. Quelles conséquences dès lors peut-on utilement tirer de leurs principes? Je ne peux ajouter foi aux conséquences auxquelles est conduit, à priori, un estimable et savant écrivain qui, consulté par le parlement d'Angleterre sur la question de savoir si le bas prix de la main-d'oeuvre en France ne permet pas aux manufacturiers français d'établir les mêmes marchandises à plus bas prix que les manufacturiers anglais, a soutenu devant un comité d'enquête, et en dépit de l'expérience de tous les manufacturiers, que le taux des salaires n'a aucun effet sur le prix des marchandises.

(Say 1843 [1828-9]: 22)

We return to the 'Discours préliminaire' to the Traité of 1826. Newly inserted is a further sharply worded condemnation of the 'metaphysical' procedures of Ricardo's 'partisans' who aggravated the weaknesses of the master - all in the course of making wholly unjustified 'revolutionary' claims on Say's own behalf:

Depuis la mort de Ricardo, cet auteur a fait secte. Ses partisans ont prétendu qu'il avait changé la face de la science, comme si l'on pouvait changer des faits décrits et caractérisés, à moins de prouver qu'ils sont faux; ce que Ricardo n'a pas fait ni pu faire. Mais pour montrer qu'il avait fait une révolution dans la science, ils ont exagéré les défauts qu'on peut lui reprocher: ils ont tiré toutes leurs conséquences d'un petit nombre de principes, en fesant abstraction de tous les autres, et sont arrivés en effet à des résultats différens des cas réels, qui sont les conséquences de l'action combinée d'un grand nombre de lois. Ils ont regardé les cas réels comme des exceptions et n'en ont tenu compte. Affranchis du contrôle de l'expérience, ils se sont jetés dans une métaphysique sans application; ils ont transformé l'économie politique en une science de mots et d'argumens; sous prétexte de l'étendre, ils l'ont poussée dans le vide. Mais cette méthode n'est pas de notre siècle, qui veut qu'on ne s'écarte pas de l'expérience et du simple bon sens; et les économistes les plus capables de l'Angleterre, tels que MM. Thomas Tooke, Robert Hamilton, et plusieurs autres, sont demeurés fidèles à la méthode expérimentale de Smith.

(Say 1826a, 1: lxxxiii-lxxxiv)

As for Ricardo himself, Say as always cited money favourably, but as an exception: 'Ricardo lui-même est fidèle à cette méthode [expérimentale] dans plusieurs parties de ses ouvrages, notamment dans ses brochures sur les monnaies, où il s'est tenu plus près des faits, parce qu'il avait pour objet d'éclaircir des questions de fait' (lxxxivn.). But even this exception was 
to be qualified in the text. Consider the 1817 references to Ricardo's ingot scheme laid out in the Proposals for an Economical and Secure Currency (1816). The first describes it as 'fort ingénieux' (Say 1817, 1: 379-80; 1819a, 1: 406-7; 1826a, 2: 78), ${ }^{4}$ and the second accords Ricardo high praise indeed as a monetary economist:

M. Ricardo, que je regarde comme l'homme de l'Europe qui entend le mieux la théorie et la pratique des monnaies, a [1817: récemment] prouvé, dans une brochure . . que le numéraire [1817: tout entier] d'un pays pouvait, sans inconvénient (pourvu qu'on pût se donner [1817: avoir] une garantie suffisante que ce pays fût bien administré), être tout entier remplacé par du papier-monnaie, et qu'une marchandise de nulle valeur pouvait, en s'y prenant bien, remplacer un métal cher et incommode, dont les propriétés métalliques ne sont d'aucun usage tant qu'on l'emploie comme numéraire.

$$
\text { (1817, 2: 29n.; 1819a, 2: 62n.) }
$$

Now this last reference is removed in 1826, while a counterpart (absent from 1819a, 1: 397-8) deletes the personal tribute and qualifies the proposal:

L'adoption d'un papier-monnaie, tel que l'a proposé Ricardo (voyez le chap. 26), aurait l'avantage de remplacer un instrument coûteux par un instrument économique; mais cette économie entraîne des risques et des inconvéniens qui outre-passent peut-être ses avantages; d'ailleurs un bon système de monnaies métalliques rend plus sûr l'emploi des billets de confiance, qui ont une partie des avantages du papier-monnaie.

$(1826 \mathrm{a}, 2: 109 \text { n. })^{5}$

In another of Say's later publications, including his entry 'Economie politique' dated May 1826 for the first issue of the Encyclopédie progressive, ${ }^{6}$ are to be found renewed complaints against Ricardo, all of which we have found that be had at one time or another abandoned. Thus in insisting on costs reflecting all three services rather than labour alone: 'dans toutes les applications pratiques, même lorsqu'il s'agit d'impôt, malgré ce qu'en dit David Ricardo, on ne risque absolument rien en s'appuyant sur le principe ici posé' (1826b: 227 n.). And in this publication too we again find reiterated the equally fallacious view that Ricardo neglected the demand for corn in expounding the 'cause' of rent - attributing it to the existence of land of unequal quality as such - with a further insistence that, in any event, Ricardo had adopted the differential-rent and zero-rent principles from the Wealth of Nations while diverging from Smith's 'excellent method'; as always, Ricardo's intensive margin disappears from sight:

En 1817, David Ricardo publia un gros volume, où, pour le fond des idées, il adopte la doctrine d'Adam Smith, mais où malheureusement, 
dans les développemens et les démonstrations, il s'écarte trop souvent de l'excellente méthode de cet auteur, pour la remplacer par des argumens subtils qui le conduisent à des résultats que ne confirment pas les faits réels. On a fait beaucoup de bruit en Angleterre de son principe que l'inégale fertilité des terres est l'unique cause du profit foncier que rendent celles de meilleure qualité. Le fait que les terres inférieures ne rendent qu'à peine les frais de culture, a été remarqué dès longtemps [Richesse des nations, liv. I, ch. 11, partie 2e]; et l'on avait attribué le profit que celles de meilleure qualité donnent par delà des frais de culture, aux circonstances où se trouve la population environnante. Partout où cette population est assez nombreuse et assez riche pour payer les produits à un prix qui permette au propriétaire du sol de réclamer un profit pour son instrument qui est le sol, il se présente un fermier. Voilà le fait et en voilà la cause. Prétendre que la quantité des produits agricoles que réclament les besoins de la société, n'exerce aucune influence sur leur valeur, c'est démentir l'expérience. ${ }^{7}$

Say also repeats the antiquated attribution to Ricardo of labour as sole source of wealth, putting it on a par with corresponding Physiocratic error: 'Prétendre que le travail est l'unique source de toute richesse, c'est la démentir également: c'est faire la contrepartie de Quesnay, qui prétendait, au contraire, que le travail ne produisait rien et que la terre produisait tout.' And once again he insists on 'experimental' as opposed to 'syllogistic' method (273-4; see above, p. 234).

The 'Histoire abrégée d'économie politique' in the Cours complet constitutes a wasted opportunity to provide a fair overview of doctrinal development and presents instead an entirely inadequate coverage of Ricardo's contribution, limited one is led to believe (apart from money) entirely to rent, and unoriginal into the bargain:

M. Malthus, dans son Essai sur la population, a fourni une belle confirmation des plus saines doctrines. David Ricardo, dans plusieurs brochures et dans ses Principes d'économie politique, a fait plus: il a montré par les faits et par le raisonnement que les valeurs des métaux, des monnaies métalliques et des signes monétaires, suivent des lois différentes, sous le nom commun d'agents de la circulation (circulating medium); et il a expliqué tous les effets qui ont été observés à cet égard. C'est maintenant une des parties les mieux connues de l'économie des nations. Je ne pense pas qu'on doive à cet estimable écrivain rien de neuf sur le profit du propriétaire foncier (the rent); $j$ 'en ai dit les raisons ailleurs.

(1843 [1828-9]: 574-5; emphasis added)

Again with respect to rent Say detracts from Ricardo's novelty, albeit that the doctrine as such is admitted to be essentially correct: 
Il me semble donc que les observations de la nature de celles faites par Ricardo, exactes quant au fond, ne sont pas neuves quoiqu'elles décèlent souvent une sagacité peu commune et soient revêtues d'une heureuse expression. A l'égard des conséquences que l'auteur en tire, il me semble que ce sont des abstractions qui n'apprennent rien et ne sont pas susceptibles d'applications utiles. J'avoue que je n'ai pas vu là dedans cette soi-disant découverte dont quelques écrivains ont fait tant de bruit. Tout en faisant le plus grand cas du mérite personnel de Ricardo, en regardant comme très précieux les développements qu'il a donnés à un grand nombre de vérités économiques, et quoique ayant moi-même beaucoup profité de ses vues lumineuses sur la théorie des monnaies, je ne peux souscrire à toutes ses doctrines et crois qu'il a quelquefois conclu les faits de ses raisonnements, au lieu de remonter, par l'analyse et le raisonnement, des faits à leurs causes.

Say pointed out that even the loyalist McCulloch recognized the earlier contribution by West and before him Anderson (see above, p. 141). The same sort of downplaying of Ricardo's contribution to rent doctrine will be found in the 1826 Traité (see above, pp. 131-2). Furthermore, when Say elaborates, it is to ignore Ricardo's endogenous or demand-determined margin, repeating the old complaint - despite awareness in 1826 of its invalidity (above, p. 132) - that for Ricardo, the rent on good land is 'due to' the existence of poor land:

Le même auteur [McCulloch] reproche à l'auteur des Recherches sur la richesse des nations, de n'avoir aucunes notions claires et exactes sur la nature et les causes du profit foncier (la rente ou le revenu du propriétaire). Il est évident que ce reproche vient de ce que Smith n'en a pas la même idée que David Ricardo, dont M. Macculloch suit les doctrines. Mais il est permis de croire que Ricardo n'en a pas lui-même une juste idée, et que, si le propriétaire d'une bonne terre reçoit un fermage, ce n'est pas par la raison que le propriétaire d'une mauvaise terre n'en reçoit point.

The Cours complet also expresses Say's continued refusal to take the intensive margin seriously, purporting to find in it an instance of 'l'économie politique métaphysique' in contrast to his own 'practical' method: 'Rien ne me paraît important que ce qui est utile et applicable' (above, p. 142).

An indication of a deliberate policy to bring into the public domain his differences with Ricardo appears in the review for the Revue Encyclopédique in September 1825 of McCulloch's Discourse. In this article Say rehearses the full range of superannuated complaints, ${ }^{8}$ and explains in terms of his personal regard for Ricardo why he had not hitherto been more outspoken in public 
regarding those differences - even the Notes of 1819 had played them down and hints at a plan to publish his correspondence with Ricardo to bring his objections fully into the light of day:

M. M'Culloch me reprochera peut-être de n'avoir pas fait connaître plus tôt ma façon de penser à l'égard des doctrines de Ricardo. Je me serais reproché encore plus de causer la moindre affliction à un homme aussi recommandable, qui m'honorait de son amitié, dont toutes les pensées, depuis qu'il s'était retiré des affaires, étaient tournées vers le bien public, dont, au total, les travaux ont été favorables au progrès de la science qu'il cultivait, à un homme, enfin, qui était aussi peu porté à tirer vanité de son savoir que de sa fortune. Aussi n'ai-je touché que très-légèrement dans les notes que les libraires m'ont sollicité d'ajouter à la traduction française de son livre, les points sur lesquels nous différions; mais, on verra peut-être quelque jour, par notre correspondance, que, si j'ai évité de le combattre sous les yeux du public, je soutenais néanmoins à huit clos contre lui quelques combats dans l'intérêt de la vérité.'

(Say 1825: 718-19; emphasis added)

Now Say did in fact have a project to publish the correspondence and made modifications to some of the originals to that end, confirming a wish to distance himself from Ricardo. I refer to the adjustments to the letters of 19 July 1821 and 1 May 1822 (see above, p. 158). They were unpublished during Say's lifetime and must be approached with caution, but they are suggestive nonetheless.

The first revised letter closes - compare the two versions - with an added 'jibe' (Sraffa's term) at Ricardo's syllogistic abstractions and praise for Say's own practical method:

C'est avec beaucoup de plaisir que j'apprends que vous avez formé en Angleterre, un Club d'Economistes politiques; et je ne doute pas qu'il ne contribue puissamment à repandre les principes de cette science. Je m'estimerais heureux d'y être associé. En attendant si vous croyez que nos controverses puissent intéresser ses membres, je vous engage à leur communiquer cette lettre.

(Say, in Ricardo 1951-73, 9: 36)

C'est avec bien du plaisir que j'apprends que vous avez formé à Londres un club d'économistes politiques; et je ne doute pas qu'il contribue puissamment à répandre les principales vérités dont se compose cette science. Ce que je désire par-dessus tout, c'est que ceux de ces principes qui ne sont point abstraits, ceux qui ne sont que l'exposition naïve des faits et de leurs conséquences, se répandent dans toutes les classes des citoyens. Nous n'avons pas besoin de former des controversistes habiles 
dans l'arme du syllogisme, mais des économistes pratiques; or, il ne faut pour cela que des notions accessibles au simple bon sens. Ce que je crains, c'est que nous ne rebutions le commun des hommes par des raisonnements trop abstraits. Si vous admettez des associés étrangers, je m'estimerai heureux d'être membre d'une société si respectable.

(Say 1843: 607)

As for substance, the two versions start out with thanks for the gift of the third edition of the Principles and a remark that 'tout en cherchant la vérité de bonne foi, et après que nous avons, les uns et les autres, consacré des années entières à approfondir les questions que présente cette science', there still remained differences between them - Malthus too is mentioned in the version actually sent (Say, in Ricardo 1951-73, 9: 31; Say 1843: 605). But there are two added paragraphs in the revised version, the first of which again refers gratuitously to Ricardian 'abstractions' with special reference to rent and profit theory - despite Say's adherence to much of the Ricardian doctrine, as has been documented in Chapters 2 and 3:

Vous pensez que mon ouvrage vaudrait beaucoup mieux si j'approfondissais davantage les lois qui déterminent le taux des fermages et celui des profits. Mais, permettez-moi de vous dire, mon cher monsieur, que ces questions me paraissent moins importantes qu'à vous, et que j'évite, par-dessus tout, des abstractions qui n'ont, je vous en demande bien pardon, rien d'applicable dans la vie réelle.

(Say 1843: 605)

The revised letter also elaborates the long-standing position that Smithian 'value in use' as such was neither operational nor relevant, since all that mattered for value determination, and thus inclusion within 'riches', was that particular element of utility reflecting costs relating to labour, capital and land:

Je ne saurais admettre ce que vous appelez, avec Adam Smith, value in use. Qu'est-ce que de la valeur en utilité, si ce n'est de l'utilité pure et simple? Le mot utilité suffit donc; mais l'utilité seule ne me donne point encore une idée de la valeur. Continuant à l'étudier, j'observe qu'il y a, dans chaque produit, une portion de cette utilité que la nature nous offre gratuitement, et une portion que nous créons, en travaillant et en faisant travailler avec nous nos capitaux et nos terres. Mais, comme aucun de ces différents services ne s'offre gratuitement, il arrive que, lorsque nous avons créé cette portion d'utilité qui est coûteuse, nous ne consentons à céder les droits que nous avons sur elle, qu'autant que l'on nous donne en échange une autre portion d'utilité, créée de la même manière et aux mêmes frais. 
Here Say is expounding the Ricardian cost theory of value determination apart from the inclusion of rent and - as we have emphasized in Chapter 3 (above, pp. 99-100) - in terms consistent with the marginal-utility perspective. Nevertheless, he goes on to insist that whereas Ricardo measured the element of utility that counted in price determination by the labour input alone, he himself relied on measurement in terms of exchange value - a perfectly circular argument:

Maintenant, comment pouvons-nous mesurer l'étendue de l'utilité que nous avons créée dans un produit? Vous, monsieur, vous croyez, si je ne me trompe, que c'est par la quantité de travail qu'on a dépensée pour la créer; or, je prends la liberté de ne pas adopter cette appréciation; il y a des multitudes de qualités diverses dans le travail; on ne peut mesurer la quantité de chacune d'elles. Je mesure cette utilité, mise dans les produits, par les diverses quantités d'un autre produit que l'on consent à donner pour l'acquérir. Une utilité pour laquelle, sur le marché, on offre deux boisseaux de froment, vaut le double de celle pour laquelle on n'offre qu'un seul boisseau. C'est ici seulement que commencent les idées de valeur et de richesses, telles qu'on les conçoit dans la société; c'est ici seulement que commence l'action des lois de l'économie politique.

That for Ricardo costs include solely the labour element - this is repeated in the modified letter: 'Le travail ne détermine donc pas SEUL la valeur des produits, ainsi que vous l'établissez dans vos ouvrages' (607) - is an attribution that Say himself had abandoned (see above, p. 135), while the differential-rent and zero-rent (extensive) margin are to be found in the 1826 Traité and even earlier (see above, pp. 119, 135-6; also 64-5).

We turn to the letter dated 1 May 1822 (Ricardo 1951-73, 9: 188; Say 1843: 609). The substance of the defence against Ricardo's charge that Say fell into self-contradiction in the Catéchisme and the Lettres à Malthus is much the same in both versions. But the modified version reverts again to the alleged 'abstraction' entailed in defining 'riches' in product terms - the context entails riches as stock of goods - independently of value in exchange:

Du reste, je ne pense pas que nous devions avoir la prétention de donner des définitions abstraites, notamment de la richesse; c'est-à-dire une définition où nous ferions abstraction du possesseur et de la chose possédée. C'était ainsi que procédaient les disputeurs du moyen âge; et c'était, je crois, la raison pour laquelle ils ne s'entendaient jamais. Une définition trop générale et qui n'entre pas dans les particularités qui distinguent chaque objet, n'apprend rien. Ne vaut-il pas mieux faire connâiitre un objet à mesure que l'on peut lui appliquer les caractères qui le distinguent? Le lecteur alors en conçoit nettement l'idée.

(Say 1843: 610) 
In the original, Say had merely written: 'Il me semble que cette doctrine' his own concept of riches - 'explique tous les phénomènes et qu'elle est conséquente au principe que la richesse que l'on possède, est en proportion de la quantité de choses que l'on peut acquérir par son moyen' (Say, in Ricardo 1951-73, 9: 191). Say was thus unearthing and putting on display the old disputes (all resolved of course in his own favour), despite the agreement regarding riches as real-income flow, not measurable in value terms, as has emerged in Chapter 4.

Certain revisions illustrate the manner in which Say made various concessions. Consider a smoothly formulated commendation of Ricardo in the second modified letter for, in effect, abandoning his alleged position that costs comprise only labour. It is made in reaction to Ricardo's remark in his letter of 5 March 1822 on the price of bread: 'I object to lumping the productive services altogether, I want to know the part which each performs in giving value to bread' (above, pp. 84-5):

Savez-vous bien, mon cher monsieur, que votre lettre contient un aveu précieux que je regarde comme un hommage rendu à la vérité. C'est quand vous dites que vous n'aimez pas à mettre en un bloc les frais de production, et que vous avez besoin de savoir dans quelle proportion chacun d'eux donne de la valeur à un produit. Il m'avait semblé que jusqu'ici vous n'accordiez ce privilège qu'au travail ou à l'industrie; et que vous le refusiez au fermage et à l'intérêt du capital. En parlant ainsi des différents frais de production, vous approuvez implicitement l'analyse et l'estimation que j'ai essayé d'en faire.

(Say 1843: 610)

Taking Say's commendation at face value, it is remarkable that a brief comment in late correspondence had more effect than what is explicit in the Principles: that is, that profits are included by Ricardo in cost price. But, as we mentioned above, Say by this time was very well aware of their inclusion. His praise was double-edged.

\section{An hypothesis}

How are we to account for Say's growing hostility, much of it - if not most of it - unjustified by genuine differences between the parties? I suspect we must have recourse to psychological matters, for there is some indication of increasing sensitivity to criticism and corresponding defensiveness which might go at least some way to provide an explanation.

Before justifying this hypothesis, we should have in mind British opinion regarding Say. We find James Mill writing to Ricardo on 24 November 1814 of Say's 'excellent book', referring to the 1803 edition of the Traité, and of his attempts to arrange a meeting between Say and Ricardo on the former's visit to Britain (in Ricardo 1951-73, 6: 156). After meeting Say, 
Ricardo gave a mixed evaluation distinguishing between technical matters and personality:

He does not appear to me to be ready in conversation on the subject on which he has very ably written, - and indeed in his book there are many points which I think are very far from being satisfactorily established, yet he is an unaffected agreeable man, and I found him an instructive companion.

(Ricardo to Malthus, 18 December 1814; 161)

Ricardo next met Say in Paris in Summer 1817 (in Ricardo 1951-73, 7: 168), and subsequently wrote to him that

[t]he esteem for your excellent book on Political Economy [1817] is daily increasing in this country, and only because it daily becomes better known. It has been lately reviewed with mine in the British Review, and due respect has been paid to its merits.

(18 December 1817; 231)

But this is very general and after a later visit to Paris, Ricardo wrote of Say in less positive terms. After remarking that he 'never found him much inclined to talk on the points of difference between us', he reported the negative opinion of a third party:

Speaking to the Duke de Broglie of M. Say he observed that he did not appear to him to have the least notion of the doctrines of the New School, - that his notes in the French translation of my book shewed clearly that he did not know what the subject in dispute was.

(Ricardo to Trower, 14 December 1822; in Ricardo 1951-73, 9: 244)

That Ricardo shared this view is confirmed when he wrote at this time to Malthus: 'Neither he [Garnier] nor M. Say have succeeded in at all understanding what my opinions are' (16 December 1822; 249). Two years earlier, in his letter to McCulloch of 23 November 1820, Ricardo had written regarding the revised Traité of 1819, that

I have looked over carefully all the new matter in his fourth edition without discovering any thing to induce me to alter the opinion which I have given of the confusion of his ideas respecting value... The book I think is altogether an able one, but I am quite convinced that M. Say does not see quite through the subject.

(Ricardo 1951-73, 8: 299)

And on 24 November 1820 he had complained to Malthus regarding the Lettres that Say is very unjust to me, and evidently does not understand my 
doctrine' (above, p. 75). Ricardo's low opinion of Say's Notes of 1819 has been documented in Appendix I.

As for published statements, Ricardo does write warmly of the Traité in the Preface to the Principles, but largely with respect to its excellent exposition of Smithian policy recommendations and to matters of organisation:

the excellent works of M. Say, who not only was the first, or among the first, of continental writers, who justly appreciated and applied the principles of Smith, and who has done more than all other continental writers taken together, to recommend the principles of that enlightened and beneficial system to the nations of Europe; but who has succeeded in placing the science in a more logical, and more instructive order.

(Ricardo 1951-73, 1: 6-7)

He goes on to add that Say had 'enriched' the science 'by several discussions, original, accurate, and profound', though the only specific illustation provided is the chapter 'Des débouchés'.

McCulloch, in correspondence with Ricardo dated 28 November 1820, expressed himself harshly with respect to the Lettres à M. Malthus as well as the Traité, exception made for 'Des débouchés', organization and style:

I am tolerably well acquainted with the fourth Edition of Say, and I quite agree with you that the notions of value which pervade it are nearly as confused as in the previous ones - It is astonishing that he should still adhere to his old opinions on the subject of rent; and it is much to be lamented that so popular a work should be erroneous in so important a particular - After all however the great merit of Say's work seems to me to consist almost exclusively in the luminous arrangement of the parts and the perspicuity of the stile - Excepting the Chapter Des Débouchés it contains no disquisition that can be said to be either original or ingenious - It is sensible and well written and that is all - I have just glanced at his Letters to Malthus, but have not read them through - They struck me as being decidedly inferior to his other work; and I cannot help thinking that your taking any very particular notice of them would be doing them an honour to which they have no just title.

(McCulloch, in Ricardo 1951-73, 8: 312-13)

In the Discourse, however, McCulloch - citing Ricardo's Preface - wrote more positively of the Traité that, apart from its 'well-digested and luminous exposition of the principles of Dr. Smith' and 'the great and unquestionable merit that it possesses from its clear and logical arrangement, and the felicity of many of its illustrations, "it is enriched with several accurate, original and profound discussions"' (McCulloch 1825b: 64). But again, the only specific instance provided relates to the demonstration 'that no conceivable increase of the powers of production can ever occasion a general glut' (65). 
How far Say would have been aware of the hostile unpublished British opinion it is difficult to judge, but one suspects that some of it must have trickled through to him. The more moderate tone of the formal statements noted above would have to be weighed in the balance, but it is doubtful whether anything could have effaced the effect of a derogatory review in the Scotsman of Prinsep's translation of the 1819 Traité (McCulloch 1821). This unsigned review, appearing in a newspaper commonly known to be edited by McCulloch (O’Brien 1970: 22-5), denigrates in acerbic terms Say's general performance as innovatory scientist - exception made for the Law of Markets - while according double-edged praise for matters of organization and style and for an exposition (quite unnecessary for British readers) of Smithian principles. ${ }^{10}$ That McCulloch himself contributed the review - it has to be read to be believed (see Appendix III) - would have been obvious from internal evidence. (Of its main theme, incidentally, Ricardo privately approved: 'The criticism on Say in the last number of the Scotsman is I think very just - he is certainly very far behind in his knowledge of the present state of the science'; to McCulloch, 25 April 1821, in Ricardo 1951-73, 8: 374.) Against this, Say must have been pleased by his election as honorary member of the Political Economy Club and the role played by Ricardo, who communicated Say's request to be associated (see above, p. 273) on 4 February 1822; Say was then proposed as an honorary member and elected at the next meeting on 4 March (Ricardo 1951-73, 9: 172-3n.).

Whether or not Say perceived and reacted to a hostile evaluation of his work, a certain defensiveness may already be discerned even in earlier editions of the Traité. Thus he makes the self-congratulatory remark regarding taxation - and we know that, after 1817, Ricardo had become the target in this context - that 'l'écrivain honnête homme est heureux de pouvoir prouver que la modération n'est pas une duperie' (1814, 2: 303-4; 1817, 2: 313-14; 1819a, 2: 341-2; 1826a, 3: 161). In the 'riches' context he wrote to Ricardo himself that

on serait injuste de me reprocher la longueur et la complication des définitions de richesses qui reposent sur toutes ces idées. Pour caractériser une chose, il faut bien énoncer tous les caractères qui lui sont propres et qui la différencient d'une autre chose.

(1 May 1822; in Ricardo 1951-73, 9: 190)

And on the same subject he insisted in the Traité that he himself had no axe to grind:

[1814, 1817: En commençant cet ouvrage, j’ai dépouillé tout système.] Que voulais-je prouver? Rien. Je voulais exposer comment les richesses se forment, se répandent et se détruisent; de quelle manière [1814: comment] pouvais-je acquérir la connaissance de ces faits? En les observant. C'est le résultat de ces observations que je donne. Tout le monde peut les refaire.

(1814, 1: 1x; 1817, 1: lvii; 1819a, 1: lxii) 
This insistence on scientific disinterest is reworked and much expanded in 1826 in an autobiographical remark:

Élevé dans le commerce et pour le commerce, mais appelé par les événemens, à m'occuper des affaires publiques, j'y ai porté quelque expérience que n'ont pas toujours les administrateurs et les gens de lettres. On peut donc regarder ce livre comme le fruit de la pratique aussi bien que de l'étude. En l'écrivant, je n'ai eu aucune vue d'intérêt personnel; je n'avais aucun système à soutenir, aucune thèse à prouver; mon but était simplement d'exposer comment les richesses se forment, se répandent et se détruisent: de quelle manière pouvais-je acquérir la connaissance de ces faits? En les observant. C'est le résultat de ces observations que je donne. Tout le monde peut les refaire.

(1826a, 1: lxxvii-lxxviii)

Indicative too is a note added to the Traité in 1819 correcting earlier statements that the value of a commodity was to be measured by value (Chapter 2, note 11), a correction Say admitted was due to critics, however unjust they might have been on other issues: 'La mesure de la valeur est la quantité d'un autre produit. Il résultait de cette erreur du louche dans plusieurs démonstrations. C'est ce que diverses critiques, même injustes, m'ont fait apercevoir' (1819a, 2: 4n.). This note is removed in 1826 being no longer relevant, but the measurement of exchange value by quantity is reiterated in the text at the very outset of the Traité (1819a, 1: 2; 1826a, 1: 2-3), and to this Say in 1826 attached a very defensive note:

Je ne présente ici sur les richesses et la valeur des choses, que ce qui est indispensable pour mettre le lecteur en état de comprendre le phénomène de la production des richesses. Les autres traits qui achèvent de caractériser les richesses et les valeurs se montreront au lecteur à mesure qu'il avancera. Quelques écrivains anglais en ont pris occasion d'attaquer mes définitions comme vagues et incomplètes; mais j'aime mieux m'exposer à cette accusation que de présenter des définitions qui, pour embrasser tous les caractères de la chose définie, rempliraient plusieurs pages et n'offriraient que des abstractions incompréhensibles, jusqu'à ce qu'elles fussent justifiées par des faits qui ne peuvent se développer que subséquemment. Il me suffit que les caractères que j'assigne ici soient les plus saillans, et que, loin d'être effacés, ils se trouvent confirmés par tout ce qui doit suivre.

(1826a, 1:3n.)

Almost certainly Bailey (1825) and probably McCulloch (1825 [1823]: 8) and Malthus (1986 [1824], 7: 258) were included amongst the '[q]uelques écrivains anglais' here referred to. The 'Discours préliminaire' in 1826 goes so far as to represent the British writers in general as concerned not with 'instruction' but with mutual conversion campaigns regarding socially irrelevant issues: 
Il s'en est suivi d'interminables discussions, où les contendans semblent avoir eu pour but, non de répandre l'instruction, mais de se convertir mutuellement; où chacun, en oubliant le public, n'a cherché qu'à soutenir son dire; de là des controverses quelquefois peu intelligibles, souvent ennuyeuses, et qui ont eu ce fâcheux effet que les gens du monde, ignorant les solides bases sur lesquelles l'économie politique repose, ont pu croire qu'elle était retombée sous l'empire des systèmes et des opinions individuelles, que l'on n'était d'accord sur rien; quoiqu'en effet les bons auteurs s'accordent sur toutes les bases essentielles, conviennent des mêmes faits et indiquent les mêmes moyens pour parvenir au but des vrais publicistes: la plus grande prosperité des nations.

(Say 1826a, 1: xxxv-xxxvii)

The passage follows immediately after the charges against Ricardo that 'les résultats obtenus par l'auteur anglais sont fréquemment démentis par l'expérience', with particular reference to the absence of rent from costs, and against McCulloch's rendition in his 1824 evidence of the inverse wageprofit relation (above, p. 256). Say adds gratuitously, in a note citing Bailey, that several English economists 's'en plaignent eux-mêmes et accusent ceux de leurs compatriotes qui font de la métaphysique sur l'économie politique, de chercher dans l'obscurité même un moyen de succès' (xxxvi).

Yet more strongly than all this, most (if not all) Ricardians - exception made for Ricardo himself - are represented by Say as men of ill will in a further footnote attached at the outset of the 1826 edition to the discussion of the effect of technical change in raising the exchange value of 'riches' in the sense of the real purchasing power of nominal incomes, a matter we have discussed at length in Chapter 4. The passage in question, by insisting on conflict with Ricardo where none exists, tells us much of Say's 'mood':

Cette doctrine sera plus développée au second livre de cet ouvrage, où j'examine en quoi consiste l'importance de nos revenus; mais je me suis vu forcé d'en dire un mot dans ce chapitre, qui s'est trouvé vivement attaqué par Ricardo, dans la troisième édition de ses Principes d'Économie politique, chap. 20. Je n'aurais pas fait ici l'apologie de ma doctrine si elle avait été attaquée par un homme moins justement célèbre; car s'il me fallait défendre les principes établis dans ce livre-ci contre toutes les critiques dont ils ont été l'objet, je serais forcé d'en doubler le volume. Les raisons que je donne sur chaque point ont paru suffire aux lecteurs qui ont cherché de bonne foi à s'en pénétrer.

(1826a, 1: 37n.; emphasis added)

In the same manner, to Ricardo's criticisms in 1821 of his analysis of the English land-tax system (Ricardo 1951-73, 1: 186f.), Say responds politely in 1826 but reveals his disdain for the general run of critics as lacking both competence and good faith: 
Je ne m'arrête aux critiques qu'on fait de mes ouvrages, et qui me parraissent peu fondées, que lorsque mon critique, comme c'est ici le cas, peut faire autorité par sa haute capacité et son incontestable bonne foi. Si je voulais répondre aux autres, je doublerais le volume de cet ouvrage aux dépens du lecteur.

(1826a, 3: 213n.; emphasis added $)^{11}$

Say, we conclude, engaged in a systematic campaign, especially after 1823, to distance himself in the public estimate from Ricardo and the Ricardians rather than seek to emphasize common ground. It is difficult not to discern a tone of resentfulness and ill-humour as he proceeds, which we have suggested might partly be accounted for in terms of his sensitivity to criticism and correspondingly excessive defensiveness. ${ }^{12}$ Evidence of sensitivity is not restricted to the Ricardians. Malthus comes under fire for failing to appreciate Say's priority in devising an 'Epitome des principes fondamenteaux de l'économie politique' (see above, p. 231). This protest is preceded by a soup̧on of a hint that Malthus was partly motivated by national prejudice:

M. Malthus juge, d'après ces règles, une partie des termes employés par les partisans de Quesnay, par Adam Smith, par J. B. Say, par Ricardo, par Mill, par Macculloch, et par l'auteur anonyme d'une Dissertation sur la nature, la mesure et les causes de la valeur. Il a souvent raison dans ses critiques; mais il faut convenir qu'il y met souvent aussi un peu de légèreté, surtout lorsqu'il n'a pas affaire à ses compatriotes. Par exemple, il reproche à l'auteur de cet article, d'avoir, dans l'emploi qu'il a fait du mot utilité, violé les quatre règles précédemment posées.

(1827a: 495; emphasis added)

On the following page there is some compensation in the praise for most of Malthus's definitions and accompanying discussions, which would be 'trèsutiles aux Français qui sont jaloux de se familiariser avec le language des économistes anglais', though subject to a qualification we have become used to expect: that is, that his faults reflect contamination by the Ricardians,

car, on doit cette justice à l'estimable auteur de ce petit ouvrage, qu'avec un amour sincère de la vérité, son langage est simple et clair, toutes les fois qu'il n'est pas obligé de suivre ses antagonistes dans les abstractions dont ils ont hérissé une science qui devrait consister seulement dans l'exposition des faits et de leurs conséquences immédiates.

Say's sensitivity is also apparent in a sharply worded retort to Sismondi's position that orthodox theorists were incapable of understanding British crisis conditions; Sismondi had failed to take proper account of the Traité: 
on pourra reprocher à l'estimable auteur que je suis forcé de combattre, de s'être complètement mépris sur beaucoup d'autres causes également puissantes; de s'en prendre aux capitaux, de s'en prendre aux revenus, sans avoir peut-être assez étudié les fonctions des uns et la source des autres. Il prétend qu'embarrassés à decider ce qui était capital, ce qui était revenu, nous avons trouvé plus simple de retrancher absolument le dernier de nos calculs. Ne pourrais-je pas lui reprocher à plus juste titre, d'avoir oublié que dans mon Traité d'économie politique, j'ai consacré le quart d'un volume à décrire les fonctions des capitaux, et le quart d'un autre volume à rechercher la source de nos revenus, aussi bien que les causes qui les augmentent ou les diminuent. Quand il aura montré que je me suis trompé sur tous ces points, et que les choses ne se passent point de la manière que j'ai décrite, alors j'accueillerai avec reconnaissance les vérités nouvelles qu'il aura substituées à mes erreurs.

(Say 1826c: 45)

There is a little more to add by way of summary. Say's refusal to deal properly with the serious technical considerations raised by Ricardo's intensive margin illustrates his 'desultory' fashion of responding to critics and his unfairness in retreat (above, p. 263). And an unwillingness to be in the least generous manifests itself in his depriving Ricardo of almost any credit for a serious contribution, even when he himself is working with canonical concepts. This latter can be seen too, we might add, in his attitude towards Malthus. The population principle is attributed to Steuart and various unnamed 'reputable authors' and said to be only 'confirmed' by Malthus who deserved honourable mention for impressive applications rather than origin-

ality (1843 [1828-9]: 371n., 374). Say then points to his own treatment of population in 1803 further diluting any obligation to Malthus:

J'avais eu le bonheur de me rencontrer avec Malthus sur les conséquences importantes de ce principe, dans la première édition de mon Traité d'économie politique qui fut publiée à peu près dans le même temps qu'il donna la première édition de son Essai sur la population.

And when he goes on to insist that prudential control must be viewed as a check entailing a variety of 'misery' (376-7, cited above, p. 242), he gives not even a hint that this is a central feature of Malthus's view of the matter. $^{13}$

There is a qualification to this rather bleak evaluation. It is Say's response of 1824 to Sismondi's fears that technological progress would generate an unsustainable flow of output, where Say links his own name with Ricardo's: 'Cette doctrine contredit celle que David Ricardo et moi nous avons cherché 
à établir dans nos ouvrages'; and he goes on to write of a moral obligation to defend the reputation of a man who had died only a few months earlier:

Ricardo n'existe plus. Les philanthropes de tous les pays, qui ne font actuellement qu'une même nation, le regretteront longtemps. Ce sentiment et l'amitié qui en particulier m'unissait à lui m'imposent peut-être le devoir de le défendre contre une attaque qui nous est commune.

(1848 [1824]: 250)

Again, in 1826 Say responds to Sismondi's (forthcoming) second edition of the Nouveaux Principes in terms of Ricardo's monetary principles: 'Loin d'infirmer les lois naturelles de l'économie politique découvertes par les bons auteurs' - as Sismondi maintained - 'la dernière crise commerciale les confirme pleinement. Elle est expliquée par les principes de Ricardo sur les monnaies' (1826c: 42-3). ${ }^{14}$ But the honourable mention of Ricardo is subject to the usual insistence that monetary principles constituted 'la seule partie peut-être de la science où [Ricardo] nous ait appris des vérités importantes et nouvelles' (43). ${ }^{15}$ 


\section{Appendix I}

\section{Say's Notes on Ricardo's Principles}

Writing to Trower on 23 August 1817, Ricardo alludes to Say's first reaction to the Principles and his intention to make use of the notes he was taking in preparing the next edition of the Traité:

I can give you but little information respecting the criticisms on my book, - indeed I have heard of none but from M. Say, and Mr. Malthus for some months past. The former I saw several times at Paris, - he was very friendly and agreeable - spoke favourably of my book - was quite sure that in a very few years there would not be a shadow of difference between us, but he complained that I had made demands too great on the continued exercise of thought on the part of my reader, and had not sufficiently relieved him or assisted him by a few occasional examples, and illustrations, in support of my theory. He said that he was reading me with a pen in his hand, making notes to be employed in the next edition of his work, and he found it required all this attention to follow me. In the last edition of his work [Say 1817], published before my book appeared, he has spoken of me in very flattering terms, far exceeding my deserts.

(Ricardo 1951-73, 7: 178)

Say's Notes finally appeared in the Constancio translation of the Principles with publication date 1819. On 22 December 1818 Ricardo mentioned to James Mill that his publisher Murray had 'received a copy of a translation of my book into French, with copious notes - he would have sent it to me, but he thought I should receive a copy through the means of Say' (361). He added: 'I fear that Say is not quite friendly towards me, but I am sure that he is not just if he is otherwise.' Mill replied (24 December 1818) that he had received the pre-publication copy from Murray and spoke contemptuously not only of the Notes but of Say himself:

I am full of contempt for these notes of Say. Murray sent me the book immediately; and you may say to him, when you write, that I am much obliged to him. There is not one of your doctrines, that he has seized, or 
perceives the force of in any degree. Think of his saying, in, I believe, the very first of his notes, that you have assuredly in the text committed a great error, because in talking of exchangeable value, you have not included profits of stock and rent, as constituent parts. This is to declare, as plainly as words can speak, that the man knows not in the smallest degree what your book is about. As far as I have yet gone (for I dare say I shall be tempted to read the whole of the translation) all his notes appear to be of the same stamp. They sink the man in my estimation to a very inferior level.

(Mill, in Ricardo 1951-73, 7: 375)

Mill goes on to ask whether Ricardo intended to print the Notes at the end of a new edition of the Principles or ignore them. Ricardo replied (28 December) that he would leave it to Murray to decide, but he himself was quite indifferent considering their poor quality:

I have left it to Murray to do as he pleases respecting translating the notes, and adding them to the end of the work. If they were much more able I should both from my wish to have the subject well discussed, and from a feeling of pride in having a distinguished and able adversary have liked to have made them as public as I could, although it might have been thought that I had the worst of the argument, - but now it is quite indifferent to me.

Provisionally he thought he might limit any response to Say's criticism of the differential-rent doctrine, pointing out that Say had entirely neglected the intensive margin: 'I think of making no other answer to M Say's observations but that of remarking that he has left my main position respecting the regulator of rent unanswered.'

Say sent a copy of the Constancio translation to Ricardo, pointing out that while the annotations had been written solely for his personal use spelling out only the points where he disagreed - he had been 'persecuted' to allow them to be attached to the translation:

J'avais ecrit quelques notes sur vos Eléments [Principles], uniquement pour mon usage, et par conséquent j'avais dû laisser sans remarquer, les endroits de votre ouvrage où mes raisonnemens ne pouvaient être qu'une répétition des vôtres, à moins de ne pas les valoir. Un libraire qui fesait traduire l'ouvrage, a eu connaissance de ces notes et m'a persécuté jusqu'à ce qu'il les ait obtenues de moi.

(10 October 1819; in Ricardo 1951-73, 8: 136) 


\section{Appendix II \\ On Say's charges against McCulloch of plagiarism}

D. P. O'Brien and A. C. Darnell have defended McCulloch against the charge that he was 'a notorious plagiarizer', pointing to Samuel Read as 'the only person who ever accused McCulloch of plagiarism; and he was mistaken' (O'Brien and Darnell 1982: 217). We print below the details of Say's charge against McCulloch (see above, p. 241), provided by the 'Réducteur principal' of the Revue Encyclopédique:

L'auteur de l'article fait ici allusion au Discours préliminaire qu'on lit en tête de son Traité d'Économie politique et que M. M'Culloch a en effet fortement mis à contribution, surtout lorsqu'il trace la ligne qui sépare l'économie politique de la statistique; lorsqu'il montre l'usage que peuvent faire de la première de ces sciences, non seulement les hommes qui gouvernent, mais ceux qui sont gouvernés; lorsqu'il indique les vérités qu'Adam Smith a solidement établies, et les raisons qui font qu'une verité appartient, non au premier qui l'énonce, mais au premier qui la prouve; lorsqu'il répond aux objections contre l'économie politique tirées de la diversité des opinions de ceux qui la professent; enfin lorsqu'il se livre à une foule d'autres considérations relatives à l'histoire et aux progrès de cette science. $M$. M'Culloch a pu en user d'autant plus librement à l'égard de ce Discours préliminaire, que le libraire anglais, qui a publié la traduction anglaise du Traité de M. J.-B. Say, a jugé à propos d'en retrancher le Discours préliminaire tout entier, afin d'épargner quelques feuilles d'impression, s'imaginant peut-être que le lecteur anglais achèterait le livre sur son titre et sans s'informer s'il était ou non complètement traduit.

(in Say 1825: 698n.)

It may be taken for granted that the 'réducteur principal' inserted this note with Say's consent, indeed that Say himself contributed the details. Say, had he lived to see it, would have been happy to find explicit reference in the 1842 Principles to one of the principal methodological propositions in Say's 'Discours préliminaire' (McCulloch 1864: xiv). The passage is given above (p. 238). 


\section{Appendix II}

A second charge of plagiarism against McCulloch by Say - prefaced by a remark on McCulloch's usual anglo-centricity - is spelled out in the body of the article, with reference to McCulloch's citations from Storch's Cours d'économie politique (Storch 1815):

On voit que M. M'Culloch, comme il arrive trop souvent à ses compatriotes, n'accorde une grande attention qu'à ce qui s'écrit en Angleterre. Il s'est pourtant départi de cette règle à l'égard de M. Henry Storch qui a fait imprimer en français un Cours d'économie politique destiné à l'éducation des grands ducs de Russie. On ne peut pas deviner le motif qui a porté M. M'Culloch à vanter cet ouvrage outre mesure (voyez p. 89). Il ne peut pas ignorer que les trois quarts du livre de M. Storch ne sont qu'une copie littérale de quelques ouvrages connus.

(Say 1825: 717)

Say cites Smith, Destutt-Tracy, Bentham and his own Traité d'économie politique (717n.). 


\section{Appendix III \\ McCulloch’s review of Say 1821 [1819a]}

This appendix contains the full review by J. R. McCulloch (unsigned) of C. R. Prinsep's translation of Say's Traité (1819a).

It would be altogether superfluous to enter into any detailed examination of a work which has been so long before the public. But we think it due to the mere English reader, and to the Economists of our own country, to state, that had M. SAY's book been published in England, it would never have raised the reputation of its author to the height to which it has attained. M. SAY's principal merit consists in his having been the first, as well as the most successful of the Continental writers, who have properly appreciated the principles of Dr SMITH, and recommended them to the notice of their countrymen. The Traité d'Economie Politique is in fact a French 'Wealth of Nations'. M. SAY scarcely ever ventures to leave the track which had been pointed out by his great master. He has simplified and systematized the arrangement of the different divisions of the science; but he has rarely hazarded an original speculation (the chapter Des Débouchés is, we believe, the only exception) or made any change in the theory which DR SMITH had endeavoured to establish. It is plain, therefore, even though it were granted that DR SMITH's principles were generally sound, that M. SAY's Treatise must be far less interesting to an English than to a French reader. To the latter it was invaluable, because it adapted the greatest and most profound work which had hitherto appeared on this important science to his taste, and presented him, for the first time, with a comprehensive and well-digested view of the production, the distribution, and the consumption of wealth. To the former it can have no such recommendations. It may indeed be useful to an English reader, by enabling him more easily to ascertain the relation and connexion of the various branches of the science of wealth, and by furnishing him with some curious practical illustrations of particular doctrines drawn from the history of France and other Continental States. But these, though considerable, are trivial and unimportant recommendations when compared with the novelty, the justice and the enlarged and liberal views of the public economy and commercial policy of nations, which it first disclosed to the French. 
In the preface to the fourth edition of his work, from which the present translation has been made, M. SAY professes to have adapted it to the present improved state of the science, and tells us that it now contains a complete theory of production, and of the laws which regulate the distribution of products in different states of society. These assertions must, however, be received with very great modification. We are tolerably well acquainted with all the editions of M. SAY's book, and we do not think that those who are in possession of the $2 \mathrm{~d}$ or $3 \mathrm{~d}$ would gain much by exchanging them for the 4 th. The truth is, that M. SAY has not kept pace with the progress of the science. Throughout his whole work he confounds value in exchange with utility; though it is obvious that, when by diminishing the cost of production, we lower the exchangeable value of a commodity, and render it easier of acquisition, we really increase, instead of diminishing its utility. On some of the other fundamental branches of the science, M. SAY is still more deficient. He has a chapter 'Des Profits des Fonds de la Terre', in which he endeavours to show the fallacy of Mr RICARDO's masterly dissertation on rent. Instead, however, of doing this, he merely shows that he is either entirely unacquainted with the principles on which the true theory of rent is founded, or that he has strangely misapprehended them. But it is not merely on these rather difficult points that M. SAY' s work is singularly incomplete. We question whether he has any clear idea of the theory of population, as explained by Mr MALTHUs. He informs us that almost all writers on Political Economy, however much they may have differed on other points, agree in this, that the population of states is always in proportion to the amount of their product; and he gives us a long list of authors who had preceded Mr MALTHUs in the announcement of this truth. But it is surely unnecessary for us to inform our readers that this is not the principle developed by Mr Malthus. The Essay on Population was not published to prove that men could not live without food, or, which is the same thing, to prove that population could not absolutely outrun the means of subsistence; but to show that it had a constant tendency to exceed these means, and that unless this tendency was counteracted by the prevalence of moral restraint, it would be repressed by the prevalence of vice, want, and misery. But this most important and fundamental principle is nowhere distinctly stated in M. SAY's work; and the reader is left to conclude, that Mr MALTHUs has done nothing more than filled three volumes with the demonstration of a self-evident truth, which may be enunciated in three lines, and which had already been particularly pointed out by Buffon, Montesquieu, Quesnay, Condorcet, and a thousand others.

It is almost unnecessary, after what we have now stated, to say that we are not of opinion that the translation of this work will make any very considerable addition to the means of acquiring a knowledge of the science already in the power of the English reader. We do not mean by 
this to say that it ought to be entirely neglected; but there are works of greater importance, and it is necessary that a principle of selection should be adopted. M. SAY has himself observed that 'In those sciences which consist of mere compilation and classification, such as botany or natural history, it is hardly possible to read too much; but in those dependent on the deduction of general laws from particular facts, the better course is to read little, and select that little with judgment'. This remark is now more than ever deserving of attention. The distresses of the country have created a factitious demand for works on questions of political economy; and authors, alike ignorant of its principles, objects, and limits, and of what has been done by others, are incessantly obtruding their crude and inconsistent speculations on the public. Those, however, who wish to acquire an accurate knowledge of the science, will do well to confine their reading within a comparatively narrow circle. The great works of SMITH and of RICARDO, the 'Essay on Population' of Mr malthus, Colonel torrens' 'Essay on the Corn Trade', the present Treatise of SAY, the admirable elementary work of Mrs MARCET, and one or two others, ought to form the entire library of the young economist. After he has made himself intimately acquainted with these works, - turned them over nocturna diurnaque manu, - he will be able easier to disentangle what is good from what is bad in the ephemeral productions of the day; whereas if he were to indulge in a course of indiscriminate and ill-digested reading, without being sufficiently grounded in principle, he would be liable to be deceived by mere appearances; and would be altogether unable to distinguish between those phenomena which are the result of secondary and accidental causes, and those which are the result of fixed and general principles not dependent on any particular contingency. The framers of almost all the absurd and ridiculous theories which successively appear, endeavour to entrap the assent of the reader by making an ostentatious appeal to facts. But it should be remembered that a knowledge of facts without a knowledge of their cultural connexion and dependence - without being able to shew why the one is a cause, and the other an effect - is a very pitiful acquisition; it is in truth no better than the mechanical erudition of the mere index maker; and can afford no means of arriving at any sound or useful conclusion.

In justice to M. SAY, it ought to be added that his work has not certainly been improved by being 'done into English'. The notes added by the translator are of no value whatever. They do not set the author right where he is erroneous; and where he is right, they frequently attempt, though it must be admitted, with very little success, to shew that he is wrong. The 'Discours Préliminaire', extending in the original to 86 pages, and giving a very able view of the general objects and limits of the science, and of its progress, has been for what reason we are not informed, but we are sure it must have been a bad one, entirely 
omitted in the translation. The valuable epitome, 'Des principes fondamentaux', added by M. SAY to the fourth edition, has shared the same fate.

Of the translation itself we have merely read a few sentences, and cannot, therefore, presume to say how it is executed. It would, however, we are afraid, be too much to expect either perspicuity or simplicity in a writer who begins by telling us (preface, p. 7) that 'the son of autocratic favour has engendered the more recent and hazardous effort of Storch!' 


\section{Notes}

\section{Introduction}

1 I once read this passage as alluding to rigid prices as responsible for disequilibrium (Hollander 1992: 248). This now seems to me unlikely.

2 Even here there are considerations that somewhat narrow the gap. First, the extensions made by Malthus to Smith's 'competition of capitals' relate most specifically to the industrial sector; the Law of Markets he still applied to corn. Secondly, the problem of non-sustainable growth for Malthus entailed a danger of excessive accumulation - excessive because financed from reduced consumption rather than from increased profits; in so far as accumulation is motivated by the profit rate, as Malthus (taking the long view) believed was the case in advanced economies, there normally would not occur nonsustainable accumulation.

3 Forget adds: 'There is nothing like a corn model in Say's analysis' (see also Forget 1999: 64). She is right - but, as she herself seems to agree a little later, there is nothing like one in Ricardo's analysis either: 'It is the simplistic corn model, much more apparent in MacCulloch than Ricardo, that seems to suggest that the returns to the different factors are determined by different laws, to which Say is reacting so vehemently' (274-5).

4 But see Chapter 3, note 19 regarding Cantillon.

\section{Value, distribution and growth before 1823}

1 Ricardo here used the term utility to convey not neutral desirability but rather 'usefulness', a pound of iron having more utility in that sense than a pound of gold.

2 The second letter of 2 December 1815 was not actually sent. Sraffa conjectured that 'Say, forgetting that he had already replied on 10 September, wrote the second letter and, when he discovered his error . . . refrained from sending it' (in Ricardo 1951-73, 6: 273n.).

3 Say assumes here that demand conditions remain unchanged: 'Dans le cas toutefois où cette baisse n'influerait en rien sur la demande. Il est probable, au contraire, qu'une semblable baisse du blé changerait tous les rapports de valeur' (Say 1819b, 2: 297n.).

4 Ricardo's position assumes zero price elasticity.

5 In his Notes on the Principles Say touches on just this sort of case - totally inelastic supply - which he allows might be used by Ricardo:

M. Ricardo dira peut-être, à l'appui de sa doctrine qu'il faut bien que la quantité de travail industriel se proportionne au capital productif de la société; qu'ainsi il ne peut pas y avoir moins des chapeaux produits après l'impôt qu'auparavant; que la quantité offerte restant la même, le prix n'en peut pas monter, et que s'il y a $2 \mathrm{fr}$. d'impôt à payer, il faut que ce soit l'entrepreneur seul qui en supporte la perte.

(Say 1819b, 1: 382) 
6 Ricardo unfortunately translated 'se trouve l'avoir moins vendu' not as 'will sell less', but as 'will receive less': 'The tax ... falls then partly on the consumer who is obliged to give more for the commodity taxed, and partly on the producer, who, after deducting the tax will receive less' (1951-73, 1: 243n.). It is true, however, that Say was largely concerned - as in his Notes - with the effect of industry contraction on factor earnings, implying upward-sloping supply curves reflecting pecuniary rather than productivity considerations $(1814,2: 332-3)$.

7 Ricardo, in his Protection to Agriculture of 1822, sought to explain why it is 'the consumer ... that finally pays the tax and not the producer' (1951-73, 4: 255-6). The tax in the first instance "places [the producer] under a disadvantage, as compared with the producers of other commodities', enducing him to contract output; such diminution of supply 'will not fail to raise its price, if the demand do not at the same time diminish' (emphasis added). Now if by this is intended diminution along a given demand curve, Ricardo is, of course, mistaken in the constant-cost case; no matter what the demand elasticity the price rises by the full amount of the tax. If he is assuming increasing-supply price reflecting diminishing returns - it is after all a tax on corn that is under discussion then whether and to what extent the price rises will indeed depend on demand elasticity. (Ricardo may, however, have intended by his condition a fortuitous diminution of demand, i.e. downward shift in the demand curve.)

8 The context is the effect of poor laws in lowering the wage rate:

M. Say being impressed with the opinion that the price of commodities is regulated by the price of labour, and justly supposing that charitable institutions of all sorts tend to increase the population beyond what it otherwise would be, and therefore to lower wages, says, 'I suspect that the cheapness of the goods, which come from England, is partly caused by the numerous charitable institutions which exist in that country.' [1814] ii. 277. This is a consistent opinion in one who maintains that wages regulate price.

(Ricardo 1951-73, 1: 74n.)

In later editions, Say merely refers to the effect of charitable institutions in lowering the wage by way of population pressure, neglecting to mention the consequence for prices (1817, 2: 287; 1819a, 2: 314; 1826a, 3: 128).

9 The 1814 statement cited by Ricardo is repeated in 1817 (Say 1817, 1:249) but does not appear thereafter. Ricardo omits mention of a 'chef d'entreprise' in addition to the other employers that Say has in his original.

10 The contrast between 'value' and 'riches' is approached in the same accommodating manner - any differences between himself and Ricardo must be due to some 'malentendu' (see p. 150).

11 The repeated assertion in the foregoing extracts that 'on ne peut mesurer les valeurs que par des valeurs' creates a problem. At roughly the same time that Say was composing the Notes he was also preparing his revisions for the Traité that also appeared in 1819. Yet in the Traité we find a footnote to the opposite effect:

Dans les premières démonstrations de cet ouvrage, j'avais dit que la mesure de la valeur était la valeur d'un autre produit. Cette expression n'était pas exacte. La mesure de la valeur est la quantité d'un autre produit. Il résultait de cette erreur du louche dans plusieurs démonstrations.

(1819a, 2: 4n)

This footnote is removed from the 1826 edition.

12 Walras must have been unaware of Say's case for a stable measure, for he read him favourably as denying any conceivable candidate (Walras 1954 [1874]: 187-8).

13 The peculiar character of agriculture is to be found also in Say 1803, 2: 485. 
14 The passage in question is preceded by an extended account of the productivity advantages flowing from private property (Say 1819b, 2: 82-3).

15 Say elaborates his apologia on the 'productive function' of the landlord and capitalist thus:

fonction commode à la vérité, mais qui cependant, dans l'état présent de nos sociétés, a exigé une accumulation, fruit d'une production et d'une épargne, c'est-àdire d'une privation antérieure. Quant aux capitaux, ils sont évidemment le fruit de la production de leurs auteurs; et quant aux terres, si le premier occupant en a pu jouir à titre gratuit, à coup sûr on ne peut obtenir une terre actuellement que par une production de valeurs épargnées, égale à sa valeur.

(Say 1819b, 1: 92)

Even Say appears uncomfortable, since he ends: 'Je ne parle pas des biens qu'on a par succession ou par dons entre-vifs, qui ne changent en rien la nature et les effets de la propriété par rapport au consommateur.'

16 For Ricardo, the corn price might rise even without a fall in output, should demand elasticity be zero (Hollander 1979: 289).

17 A note commends the "new and much improved edition [which] has lately been published' - that of 1819 - and 'which is highly worthy the attention of all those who take an interest in these subjects' (Malthus 1820: 136n.). This general commendation is removed in the revisions for a second edition, Malthus inserting instead a reinforcement of his objections to Say's position:

In his 5th edition, II, 346, he describes the subject anew, but he does not seize the right view of it. He still considers the price of the produce of land which occasions rent too much as the result of a common monopoly.

(Malthus 1836: 138n.)

Malthus had in mind the proposition that '[1]a terre ... c'est le seul [agent de la nature], ou à peu près, dont l'homme ait pu faire une propriété privée et exclusive, et dont, par suite, le profit soit devenu le profit d'un particulier à l'exclusion d'un autre' (Say 1826a, 2: 346).

18 Where the passage reappears in 1826 in identical or similar form, the appropriate reference will be provided for convenience.

19 Say had written to Ricardo, two years earlier, with similar penitence, regarding the 1814 edition:

Voici, mon cher Monsieur, un exemplaire de ma $3^{\mathrm{e}}$ édition, où vous trouverez plusieurs corrections dont quelques unes m'ont été suggérées par mes conversations avec vous. Les éditions suivantes en offriront bien d'autres encore que je devrai à vos ouvrages. Ma théorie des valeurs vaut déjà mieux que celle que vous avez critiquée; il vous suffira de comparer le chap. I du Liv. II avec celui de la seconde édition, et diverses parties de l'Epitome.

(Say 21 July 1817; in Ricardo 1951-73, 7: 166)

He immediately set about improving this improved version: 'Je m'occupe toujours à corriger mon Traité d'Economie et je fais un grand usage de vos Principles of Political Economy. C'est ce que vous verrez dans ma quatrième édition que je vous enverrai peut être avant un an' (8 December 1817; 227). Ricardo made use initially of the 1814 and then of the 1819 editions, not that of 1817 .

20 The 1826 formulation of the principle reads: 'J'ai dit que le prix des produits s'établissait en chaque endroit au taux où les portent leurs frais de production, pourvu que l'utilité qu'on leur donne fasse naître le désir de les acquérir' (Say 1826a, 2: 169). 
21 Apart from this matter, Ricardo complained of inconsistency on Say's part, for maintaining (his proposition $n^{0} 5$ ) that 'the value of incomes is ... increased, if they can procure (it does not signify by what means), a greater quantity of products':

If there is no real dearness but that which arises from cost of production, (see 2) how can a commodity be said to rise in value (see 5), if its cost of production be not increased? and merely because it will exchange for more of a cheap commodity for more of a commodity the cost of production of which has diminished?

(Ricardo 1951-73, 1: 283)

22 Objections to my reading have been expressed by Peach $(1993: 36-7,270-7)$ and Steiner (1998b: 234-5, 244). These critics believe that Ricardo's expression of agreement with Say's theory of productive services is not to be taken seriously, that Ricardo simply did not wish to hurt Say's feelings.

23 There is no entry 'CHERTÉ, BON MARCHÉ' in the second edition.

24 The passage in question in fact appears only in 1817; see the entry 'SERVICES PRODUCTIFs', in 1814, 2: 474-6.

25 The 1826 version $(1826 \mathrm{a}, 3: 307 \mathrm{n}$.) is altered but the substance remains. Say there insists on referring to cost price as the 'prix réel ou original' to avoid 'prix naturel', again complaining in a note that Smith's natural price 'n'a rien de plus naturel qu'un autre'; and he points out as in 1819 - that '[i]l est fondé sur le prix courant des services productifs'. This version omits mention of the competitive process whereby market prices adjust to cost prices.

26 See also the modern French translation of Ricardo's Principles (Ricardo 1992 [1821]: 303), for this placement. Both the Brussels translation (Ricardo 1835 [1819]: 215) and the Paris translation (Ricardo 1882 [1819]: 239) simply reproduce the original and provide no help.

27 By implication, an increase in wage-goods costs will generate a compensatory rise in the money wage. But this would be a long-run response. An added note in 1819 draws on recent empirical evidence regarding the short run:

Suivant des témoignages recueillis devant un comité de la chambre des communes d'Angleterre, en 1815, le haut prix des subsistances, à cette époque, loin de faire hausser les salaires, les avait fait baisser. J'ai moi-même observé un effet pareil dans les disettes qui ont eu lieu en France en 1811 et 1817. La difficulté de vivre avait obligé plus de monde à travailler, ou obligé ceux qui déjà travaillaient à un travail plus opiniâtre; de là, surabondance dans la denrée appelée travail. Mais en même temps la classe ouvrière a dû souffrir pendant ces mêmes époques, et par conséquent diminuer en nombre.

(Say 1819a, 2: 109n.)

28 Say closes by pointing out - it is his standard complaint against Ricardo as well - that Malthus appeared to represent labour as the sole 'sacrifice':

does not this doctrine establish that our wants alone induce us to make the sacrifices by means of which we obtain productions? These sacrifices are the price which we pay to procure them; you, like Smith, call these sacrifices by the name of labour, an inadequate expression, for they are partly composed of the use derived from land and capital. I call them productive services.

(Say 1821 [1820]: 12)

29 Trower had objected specifically to 'Say's notion of immaterial services \&c.' as 'fanciful and useless'; and to 'his notion, that any man, who writes upon political Economy should banish from his thoughts the distinction between durable and perishable commodities' as 'altogether erroneous' (letter to Ricardo, 20 September 1820; in Ricardo 1951-73, 8: 249).

30 Say's letter of 10 August 1820 in fact makes no mention of the Traité of 1819, only of the Lettres à M. Malthus. Conceivably, Ricardo also had on hand Say's letter of 10 October 1819, discussed above (p. 57). 
McCulloch took up Ricardo's disparagement of the 1819 modifications to the Traité thus: 'I am tolerably well acquainted with the fourth Edition of Say, and I quite agree with you that the notions of value which pervade it are nearly as confused as in the previous ones' (28 November 1820; in Ricardo 1951-73, 8: 312). Nonetheless, Ricardo chose to rework his 'Value and Riches' chapter for the third edition, in consequence of Say's modifications to the Traité and formulations in the Lettres à M. Malthus, as he explained to McCulloch in a reply of 4 December (315). The changes to the chapter 'On Value and Riches' in fact affect nothing of substance since the main complaint remains Say's identification of value, riches and utility.

31 Ricardo also wrote to McCulloch of these notes:

Amidst a great deal of truth [in the Lettres] there appear to me to be some very grave errors - I have noticed some of them in a few pages set apart for that purpose, but there are some with which I have not meddled.

(23 November 1820; Ricardo 1951-73, 8: 298)

32 Ricardo also cites Say on Smith's

false result, that the value of all productions represents the recent or former labour of man, or, in other words, that riches are nothing else but accumulated labour; from which by a second consequence, equally false, labour is the sole measure of riches, or of the value of productions [Ricardo's italics].

(Say 1814, 1: 31; see also 1817, 1: 32; 1819a, 1: 32; 1826a, 1: 39)

33 Apart from this matter, Say observes in his reply that he failed to understand Ricardo's declaration regarding the service returns that the information is not useful and can lead to no inference whatever that may guide our future practice' (see above, p. 76). We take this matter up in Chapter 4, p. 159.

34 Conversely, there were cases where costs are incurred but no utility generated: 'Les circonstances qui occasionnent des frais sans production d'utilité, comme des impôts, ne produisent pas de la richesse; et lorsqu'on les fait payer au consommateur, on lui fait payer un prix pour lequel on ne lui donne rien en échange.'

35 Sowell has maintained that in attempting to clarify his position in 1822, Say spoke of "the last quantity of useful things" - a suggestion of the missing marginal concept essential to the utility theory of value' (Sowell 1987a: 249). The reference is apparently to Say's letter to Ricardo dated 1 May 1822 (below, p. 157). When returned to its context, the phrase cannot be read as Sowell proposes.

36 Sraffa notes editorially that this letter was written a month earlier and read to the Political Economy Club on 4 February 1822 (in Ricardo 1951-73, 9: 168n.).

37 Ricardo had actually assumed that a pound of iron yielded greater 'utility' than a pound of gold, but this is inconsequential.

38 After belatedly thanking Say (8 May 1821) for sending the Lettres à M. Malthus, Ricardo had added diplomatically:

In much of what you say in it I fully agree, but I cannot give my assent to all the doctrines which it advocates - particularly to those on which I have already spoken, and which are substantially the same as the doctrines contained in your more important work.

(Ricardo 1951-73, 8: 380)

\section{Value, distribution and growth after 1823}

1 The statement occurs in Book II, Chapter 5 'Comment les revenus se distribuent dans la société'. Relevant material from the earlier chapters on value will be taken up presently.

2 A further passage of 1826 in Book II, Chapter 2 - also found in earlier editions - clarifies more precisely that by a 'relative price change' Say intends, for example, one due to 'un besoin extraordinaire'; he evidently did not deny that a cost change affecting commodi- 
ties differentially will also entail a relative price change (1826a, 2: 190-1; also 1814, 2 : 37-8; 1817, 2: 44-5; 1819a, 2: 46-7).

3 As in the Traité, we find two qualifications in the Cours complet - that exchange value as measure of riches is a variable index and thus pertinent only to a given time and place; and that it is by its nature relative - 'Elle n'est jaimais que comparative' - neither of which characteristic disqualified it as measure as some believed (Say 1843: 34). And there is the insistence, against mercantilist prejudice, that choice of money to express value is a matter of convenience only and not to be itself confused with 'richesse'. Here Say summarizes in precisely the terms to which Ricardo had always objected so strongly, namely the identification of value, utility and riches:

si nous pouvons constater que l'on peut donner à une chose une utilité qu'elle n'aurait pas eue par elle-même; si cette utilité lui donne de la valeur, et si cette valeur est de la richesse, nous avons la certitude que nous pouvons créer de la richesse.

4 Stigler mentions Lloyd, Senior, Jennings and Hearn among those who stated clearly the principle of diminishing marginal utility while failing to apply it to economic problems; and Auguste Walras and Longfield among those who applied utility theory to economic events without explicitly developing the principle of diminishing marginal utility'. He cites only Bentham, Dupuit and Gossen as elaborating the marginal-utility principle and applying it to economic problems (Stigler 1965: 78-9).

5 See also Schumpeter's complaint that Say traced the reason for water's zero price to its value being infinitely great (1954: 599-600, cited above, p. 16). This reading seems to be based on Walras:

J. B. Say ... tells us that air, sunlight and the waters of streams and rivers are useful and therefore have value. They are, indeed, so useful, so necessary and so indispensable that their value is immense - in fact, infinite. And that is exactly why we get them for nothing. We do not pay for them, because we could never pay the price. The explanation is ingenious, but unfortunately for the argument, there are times when we do pay for air, light and water - when, for example, they are scarce.

(Walras 1954 [1874]: 203)

6 Say seems closer to his brother Louis $(1818,1822)$ than he suggests. On the one hand, he objected in the Cours complet to the latter's proposition that a measure of riches was provided by the 'inconvenience' generated by reduced supply:

Les biens qui ont une valeur d'échange constituent seuls ce que les nations nomment des richesses, parce que ce sont les seuls qui puissent procurer à celui que les possède, la jouissance de toutes les choses indifféremment qui sont capables de satisfaire ses besoins ou de gratifier ses goûts. Ce sont aussi les seuls qui soient rigoureusement appréciables. M. Louis Say, de Nantes, a cherché à donner une autre appréciation des biens; il veut qu'on mesure une portion de richesse, d'après l'inconvénient qui viendrait à résulter de sa privation; mais qui est le juge de la grandeur de cet inconvénient? Il peut y avoir sur ce point autant d'avis que de personnes. Certains gens se privent d'un bon dîner pour avoir un habit propre; d'autres se privent d'un habit pour avoir un bon dîner.

(1843 [1828-9]: 34n.)

On the other hand, he proceeds to water down the objection, should a money measure of the utility loss be used:

Une évaluation arbitraire ne saurait devenir une mesure; et, si l'on regarde comme une appréciation de l'inconvénient, la chose dont en général les hommes consentent à se priver pour en avoir une autre dont ils préferent n'être pas privés, on rentre dans l'appréciation par le moyen de la valeur échangeable; car, qu'est-ce que 
l'échange, si ce n'est l'abandon de la chose dont on consent à se passer, pour obtenir en place celle que l'on désire?

7 For earlier instances of Say's 'displacement' of value in use by value in exchange, see Say (1819b, 1: 2) and Say (1821 [1820]: 78).

8 Citations by Dupuit from the Ricardo-Say correspondence will be found in Dupuit (1933 [1849]: 99-100; 1933 [1853]: 169-70), specifically: Ricardo to Say 18 August 1815 and 8 May 1821, and Say's response to the latter 19 July 1821.

9 The 1803 version runs as follows:

La consommation de chaque denrée ressemble à une pyramide dont la largeur représente le nombre des consommateurs ou l'étendue de la demande, et dont la hauteur représente le prix de la denrée. Plus ce prix s'élève et moindre est la largeur, c'est-à-dire la demande. Il arrive quelquefois que le prix naturel de certaines marchandises s'élève au-dessus du sommet de la pyramide; c'est-à-dire à une hauteur où il n'y a plus de demande. Alors ces marchandises ne sont point produites.

(Say 1803, 2: 72-3)

The pyramid as such is absent from later editions of the Traité but the substantive arguments are unchanged (e.g. 1814, 2: 6-7; 1817, 2: 10-11; 1819a, 2: 11, 17; 1826a, 2: 162-3).

10 Say's explanation of the negative 'slope' of the market demand curve in terms of the 'income effect' is formulated thus in the Notes on Ricardo's Principles:

C'est un des faits les plus constans que la demande diminue à mesure que les prix augmentent, et la raison en est palpable. Les facultés des consommateurs s'élèvent par degrés insensibles, depuis les plus pauvres jusqu'aux plus riches; or, du moment qu'un prix s'élève, il excède les facultés de quelques consommateurs qui pouvaient y atteindre l'instant d'avant. Cette conséquence est forcée; autrement les consommateurs dépenseraient plus qu'ils n'ont à dépenser.

(Say 1819b, 1: 422)

11 To this Malthus appended a note remarking that 'M. Say's comprehensive expression, "services productifs", includes profits and rent as well as labour' though, for Malthus, 'labour will measure accurately the value of the whole amount of these services' (Malthus 1986 [1827c], 8: 100n.).

Malthus rejected a charge by Bailey (1825) that Say had neglected the relativity dimension of value, citing Say's contrast between a 'real' and a 'relative' variation of price, the former a 'change of value arising from an alteration of the charges of production; the latter a change arising from an alteration in the ratio of value of one particular commodity to other commodities' (Malthus 1986 [1827c], 8: 71).

12 Say adds that in countries such as the United States and pre-revolutionary Holland, capitalists and landlords can more easily bear a fall in their returns than can a labourer who has only one source of income (Say 1826a, 2: 256-7; 1819a, 2: 90).

13 The 'prime d'assurance', often the major quantitative element, turned on three considerations: '1 de la sûreté de l'emploi; 2 des facultés, du caractère personnel de l'emprunteur, et 3 de la bonne administration du pays où il réside' (Say 1826a, 2: 308; also 1814, 2: $101 ; 1817,2: 109-10 ; 1819 a, 2: 132)$. The texts that follow focus on matters of a historical nature, particularly 'usurious' interest rates required by lenders in the Middle Ages, ancient Greece and so forth (1826a, 2: 306-10; also 1814, 2: 99-102; 1817, 2: 108-11; 1819a, 2: 130-3), as well as the issue of liquidity (1826a, 2: 310-11; also 1814, 2: $102-3 ; 1817,2$ : 111-12; 1819a, 2: 133-4). Say's discussion seems to pertain rather to a period when loans were made less for purposes of financing 'des entreprises industrielles' than to finance wars and various other 'dissipations' and 'projets hasardeux' at a time when a legal framework was wanting (1826a, 2: 307; also 1814, 2: 100; 1817, 2:109; 1819a, 2: 131). As for the character of the borrower, that relates to his personal creditworthiness (1826a, 2: 311; also 1814, 2: 103; 1817, 2: 112; 1819a, 2: 134). 


\section{Cf. Smith:}

[T] he lowest ordinary rate of interest must ... be something more than sufficient to compensate the occasional losses to which lending, even with tolerable prudence, is exposed. Were it not more, charity or friendship could be the only motives for lending.

15 See a later reference to this citation: 'Suivant les mêmes auteurs, l'intérêt lui-même n'est pas le prix de la coopération du capital dans l'œuvre de la production. Voyez plus haut ... les raisons qui prouvent qu'ils sont dans l'erreur' (1819a, 2: 162n.).

16 Say is not entirely fair to Smith. Smith's 'profits on capital' includes interest; an element constituting 'a sufficient profit upon the risk of . . . insurance', since '[t the stock is at the risk of the borrower, who, as it were, insures it to the lender'; and also 'a sufficient recompense for the trouble of employing the stock' (Smith 1937 [1776]: 97). It is 'the trouble of employing the stock', regarded by Say as an entrepreneurial function, that Smith included in 'profits on capital'. But this latter is distinguished by Smith from 'the labour of inspection and direction', for the returns to this role he explicitly excluded from profits (48). Moreover, to treat the function of 'direction' as a special category of labour in this manner is Say's practice; indeed, when he falls back on the triple-agent classification 'l'industrie, les capitaux, les terres' - as he frequently does - entrepreneurship vanishes as such, being included within the first.

17 Say exaggerated his difference with Smith. Smith, it is true, had maintained that the ordinary rate of profit varies more or less with the certainty or uncertainty of the returns' (Smith 1937 [1776]: 110). But this uncertainty, he had also specified, was borne by the borrower, that is the entrepreneur, not the lending capitalist (see previous note), just as Say maintained.

18 The problem of the 'passivity' or otherwise of the capitalist seems to reflect in part the practical difficulty of distinguishing between interest and the entrepreneurial return. A passage in 1819 refers to the entrepreneur who supplies himself with capital:

Mais lors même qu'on n'aurait aucun moyen passable d'estimer la part qui revient au capital employé dans une entreprise, on peut être certain du moins que cette part est d'autant plus grande que le capital est plus exposé à s'y perdre en tout ou en partie, et qu'il y est plus long-temps engagé. En effet, tout entrepreneur qui a des fonds disponibles, après avoir pesé les avantages et les inconvéniens d'une profession ... préfere indubitablement, toutes choses étant d'ailleurs égales, les emplois les plus sûrs et ceux qui lui rendent plus promptement la disposition de ses capitaux. Il s'offre donc moins de capitaux pour les entreprises longues et hasardeuses que pour les autres; et on ne les emploie dans de telles entreprises que lorsque les profits y surpassent assez ceux de toutes les autres, pour les y appeler.

(Say 1819a, 2: 152; emphasis added)

19 In Cantillon's analysis too, though entrepreneurial receipts are obtained residually the entrepreneur is nonetheless said on the average to earn a certain multiple of simple wages, implying thereby a sort of normal return which is included in long-run cost price (Cantillon 1931 [1755]: 39-41). Cantillon's uncertainty thus does not imply the Knightean variety.

20 The identical passage also appears in Say (1817, 2: 130).

21 Say does not get Smith right in all respects. For example, Smith's differential favouring a relatively high money wage in seasonal industries compensates for 'dispondent moments' during the slow season, whereas Say refers merely to the fact that

[t]out travail [1814, 1817, 1819: emploi] qui n'est pas constant est [1826: nécessairement] mieux payé; car il faut qu'on le paie à la fois pour le moment où il est en exercice, et pour le moment où il attend qu'on ait besoin de lui. 
The 1814 edition adds also the remaining considerations found in the Wealth of Nations. Wages are higher 'selon qu'ils exigent des mains sûres et plus dignes de confiance' and 'selon la certitude ou l'incertitude de leurs résultats' (Say 1814, 2: 63).

22 The Lettres à M. Malthus contains reference to the labour constraint:

You observe, in several places 'that man is naturally indolent, and that it betrays great ignorance of his nature to suppose that he will always consume all he can produce' [Malthus 1820: 503]. You are right, indeed; but I maintain no other doctrine when I say that the utility of productions is no longer worth the productive services, at the rate at which we are compelled to pay for them.

(Say 1821 [1820]: 50-1)

23 Skilled labour is also treated in this manner, subject to the allowance for training costs which, if not met, would lead to supply contractions:

Cette espèce de travail est constamment un peu plus chère que l'autre; car il ne suffit pas, pour créer un homme de métier, de créer un homme adulte: il faut de plus que cet homme ait un certain degré d'intelligence et d'adresse qui, quoique fort ordinaire, ne se rencontre pas généralement chez tous les hommes; il faut en outre que les familles qui fournissent cette qualité de travail, fassent quelques frais d'apprentissage et, par conséquent, un peu plus de dépense pour élever la famille. Si leurs gains ne suffisaient pas à cette dépense, on ne trouverait bientôt plus assez d'ouvriers de métier; ce qui ferait remonter leur salaire à un taux suffisant pour en conserver le nombre.

(Say 1843 [1828-9]: 333-4)

A limit to any rise in the differential over unskilled labour is imposed by the potential inflow from the latter class:

Mais en même temps le salaire des gens de métier ne peut pas s'élever au-dessus d'un certain taux (comme par exemple le double du salaire d'un homme de peine); parce qu'alors leur classe se recrute aux dépens de cette dernière, où il se rencontre toujours des jeunes gens un peu plus intelligents, un peu plus dégourdis que les autres, qui ont bientôt fait un apprentissage.

24 Say adds: 'Voyez les notes que j’ai ajoutées à la traduction française que M. Constancio a faite de l'ouvrage de David Ricardo, tome II, page 294' (1826a, 2.: 172n.). The Notes in question are cited above (p. 38).

25 J. S. Mill at roughly the same time corrected this particular misrepresentation of Ricardo as expressed by Senior (Mill 1963-91 [1828], 4: 174). See also his Principles (Mill 1963-91 [1843], 3: 428).

26 References are given to McCulloch's Discours and his article 'Economie politique, dans le supplément à l'Encyclopédia d'Edimbourg' [sic]. See also Say 1843: 104n.

27 There is also the matter of tastes, including the demand for leisure:

Ce qu'elle peut produire ne dépend pas uniquement de l'étendue de ses fonds productifs, mais encore de ses goûts. Pour une nation apathique et paresseuse, les jouissances qui naissent du dévelopement de nos facultés physiques et intellectuelles, et celles que procurent les richesses, ne valent pas le bonheur de ne rien faire. Les hommes n'y produisent pas autant qu'on les voit produire chez une nation plus développée.

(Say 1826a, 2: 160-1)

28 The footnote appears in the 1821 edition of the Principles, but an almost identical version is to be found in 1819, since Ricardo had already seen Say's Notes when the second edition was in press. 


\section{On 'riches': real income and its measurement}

1 The parties to the debate often used 'wealth' and 'riches' interchangeably. At times, Say refers to 'richesse' as the source of income, reserving 'revenu' for the latter. On occasion he refers to 'revenu-richesse', 'richesses-nouvelles', both pointing to real-income flows. 'Richesse-réelle' is another choice.

2 The objection was addressed at Say's position in the Catéchisme that a manufacturer's inventory of his capital stock is properly made as a sum of money values (Ricardo 1951-73, 6: 248-9). As far as concerned 'capital', Say insisted strongly in his reply that it be measured in terms of a commodity the least variable, namely the monetary metal, rather than - as Ricardo implied - by labour command (272). The alternative version of this response is short and sharp - the value of money is supposed to be constant, Say expressing surprise at the need to spell this out (274).

3 In the Traité Say seems in fact to posit elastic demand as the norm: 'La valeur totale d'un produit hausse lorsque son prix particulier baisse' (1819a, 2: 419). In that case there would be no 'grande difficulté' to resolve, which is that total value might actually fall as output rises. But this problem falls away since the solution relates to real-income flows not properties of the demand curve.

4 The effect, Say adds, is the same as if there had been an actual increase in land, capital or labour: 'C'est comme si le fonds d'où vous tirez votre revenu avait doublé, soit que ce fonds fût en terres, en capital, ou bien en talens industriels' (Say 1819b, 2: 81). Exactly the same extension is to be found in a later letter to Ricardo dated 1 May 1822 relating to the same case (below, p. 158).

5 Say adds on the constancy of nominal income:

J'ai prouvé ailleurs que la baisse des produits provenant d'une économie dans les frais de production, n'altérait en rien les revenus des producteurs; un homme qui parvient à faire par jour deux paires de bas à 3 francs, gagne autant que lorsqu'il en faisait une à 6 francs.

(Say 1819b, 2: 92)

The reference is to the Catéchisme, on which see above (p. 147).

6 Once again we encounter Say's presumption that a lower unit price carries with it a lower total 'valeur échangeable'.

7 The proffered solution was addressed not only to Ricardo but also to Say's brother Louis (1818), who, like Ricardo, regarded riches as a utility concept: 'la même réponse servira pour tous deux' (Say 1819b, 2: 100). The case against Louis Say's utility dimension is also strongly expressed at this time in the Traité:

Il pose que les choses ne sont des richesses qu'en raison de l'utilité qu'elles ont, et non en raison de celle qu'on leur reconnaît. Cela est incontestable en morale; mais dans la science des richesses, on ne peut estimer les choses que ce qu'elles se vendent. L'utilité qui n'est pas déterminée ainsi, est une quantité arbitraire, vague, différente selon les personnes, dans le même temps et dans le même lieu. Ce n'est que depuis que l'économie politique a su la constater comme un fait dont elle a assigné les causes et montré les conséquences, qu'elle est devenue une science positive.

(Say 1819a, 2: 4n.)

For the 1826 version of this note, see pp. 161-2. 
8 We can now appreciate an otherwise opaque comment in Say's handwriting attached to Ricardo's letter of 5 March 1822:

Mr. Ricardo trouve là un paralogisme parce qu'il fait abstraction du possesseur, dont je ne fais jamais abstraction. Je dis que la richesse est en proportion de la valeur de ce que l'on possède, et la valeur de ce que l'on possède en proportion de ce que l'on peut acquérir. Je ne pense pas que l'on puisse parler de la richesse absolument, j'entends de la richesse dont s'occupe l'Economie politique qui est toujours relative.

(Say, in Ricardo 1951-73, 9: 170n.)

9 As for riches as stock, Say insists on his essential agreement with Ricardo:

Plusieurs écrivains des plus recommandables de notre temps, notamment Ricardo en Angleterre, ont blamé la définition que j’ai donnée des richesses, lorsque j’ai dit qu'elles se composent de la valeur des choses que l'on possède. Ce n'est point leur valeur, disent-ils, c'est la quantité d'utilité qui réside en elles, qui en fait des richesses; et ils citent, à l'appui de leur opinion, Adam Smith qui maintient avec raison qu'un homme est riche ou pauvre selon le plus ou le moins de choses nécessaires, utiles ou agréables à la vie, dont il peut se procurer la jouissance. Ces auteurs ne se sont pas aperçus que je soutiens précisément la même thèse, en disant que la richesse est en raison de la valeur, de ce que l'on possède. N'est-ce pas en proportion de la valeur de ce qu'on possède, que l'on peut se procurer plus ou moins de ces choses nécessaires, utiles, ou agréables?

(Say 1843 [1828-9]: 318)

10 In revisions to the Principles for the second edition Malthus objected to Say for adopting corn, notwithstanding

that corn not only varies greatly in the difficulty of obtaining it, from temporary abundance, or scarcity, but that very great alterations may take place for fifty or sixty years together in the same country, and in different countries, at different periods in the progress of cultivation, for a much longer period.

(Malthus 1836: 121)

11 In his Definitions (1986 [1827c], 8: 14) Malthus objected to Say's justification of the term 'utility' to underscore that by 'production' is never intended creation of new matter. This position, Malthus protested, was not maintained even by the Physiocrats and certainly not by Smith, as Say maintained (1819a, 1: 2-4).

12 For Say's championing of productive consumption from a growth perspective, see Ravix and Spindler (2003).

Say's struggle to select the correct term for final consumption is painful to read:

J'avais d'abord eu l'intention de nommer ces produits indurables; mais ce mot pouvait convenir également à des produits d'une forme matérielle. Intransmissibles n'est pas l'expression propre, car ces produits se transmettent du producteur au consommateur. Transitoire signifie passager, mais n'exclut pas l'idée de toute espèce de durée. On en peut dire autant du mot momentané.

(1819a, 1: 121n.)

13 After all that Say said against the 'materiality' condition, it comes as a surprise to find it apparently reinstated in the Cours complet:

les capitaux productifs ne consistent point en valeurs fictives et de convention, mais seulement en valeurs réelles et intrinsèques que leurs possesseurs jugent à propos de consacrer à la production. En effet on ne peut acheter des services productifs qu'avec des objets matériels ayant une valeur intrinsèque; on ne peut amasser en capitaux et transmettre à une autre personne, que des valeurs incorporées dans les objets matériels.

(1843 [1828-9]: 64, emphasis added) 
However, an attached note appears to withdraw the condition:

Il y a des capitaux qui ne sont pas incorporés dans des choses matérielles, comme la clientèle d'un notaire, d'une entreprise commerciale; mais cette portion de capital est une valeur très-réelle, et non pas seulement un signe comme ceux, qui, selon certaines personnes, peuvent remplacer les capitaux.

(64n.)

This is confusing. But in general, as Boss points out, "[i]n the Cours complet, "immaterial” capital is promoted to the status of a real private economic intermediate good. It can be traded. Like physical capital, it is owned by but not embodied in human beings' (Boss 1990: 71).

There is one final matter. In changes made for a second edition of his Principles, Malthus commended Say's position that the science of political economy arose from the possibility of quantification: 'Nothing can be more just than this. It is the main criterion to which, with a view to useful and practical conclusions, I should wish to refer' (Malthus 1836: 29). But he turned it in his own favour against Say by pointing out that though 'knowledge, talents, and personal qualities are capable of being accumulated' (28), they yet had to be excluded from wealth on the grounds that they are non-quantifiable. In sum:

If . . we wish, with M. Say, to make political economy a positive science, founded on experience, and capable of making known its results, we must be particularly careful in defining its principal term, to embrace only those objects, the increase or decrease of which is capable of being estimated; and the line which it seems most natural and useful to draw, is that which separates material from immaterial objects.

14 Much of this section is also pertinent to the Law of Markets debate.

15 Ricardo's analysis was sophisticated. In the simplest case, output of salt falls with the tax and resources are released for absorption in sectors subject to increased demand reflecting higher government expenditure. But assuming zero-elastic demand for salt and unchanged salt production, the income effect assures a fall in demand in other industries from which resources are expelled to satisfy the increased government demand (see Hollander 1992: 100-2).

16 Ricardo's alleged neglect of friction in the taxation context is taken up in the Cours complet (Say 1843 [1828-9]: 508).

17 The argument that older workers and even entrepreneurs cannot change occupation without suffering loss of earning power is to be found as early as 1803 in a discussion of the consequences of removing trade restrictions (Say 1803, 1: 291-2).

18 Striking historical examples will be found in the Épitome to the Traité under 'PRODUCTION, PRODUIRE' (Say 1819a, 2: 489-90; 1826a, 3: 310-11).

19 The 1826 version stops short after the second sentence, perhaps to avoid repetition (1826a, 3: 276).

\section{The Law of Markets}

1 Baumol (1977) provides an especially helpful investigation of several of the relevant Say texts. For a summary of secondary commentary on the evolution of the Law of Markets, see Forget (1999: 165-70; 2003: 52-6).

2 By the term 'consumption' when used alone, Say always intends 'la consommation improductive' or final consumption. By contrast, ' $[1\}$ a consommation reproductive rétabli[t] pour l'ordinaire, des valeurs supérieures à celle qu'elle détruit' (Say 1803, 2: 358). This statement is consistent with the notion of a surplus but conceivably only for the individual and not in aggregate (see above, p. 177). 
3 The passage is repeated in the third edition (Say 1817, 1: 147). The last sentence is altered in 1819 (see below, p. 201).

4 In Malthus's approach to the post-1815 depression in England the agricultural sector also played a role as trigger, but it is a series of excellent harvests and collapse of agricultural revenue and thus of expenditure that he describes (Malthus 1820: 445-6).

5 The expression 'pour que la valeur de l'argent ne chôme pas non plus' (which appears also in later editions) is rendered in the Prinsep translation of the 1819 edition as: 'for the value of money is also perishable' (Say 1880 [1819a]: 134), which seems inaccurate.

6 Here Say repeats the formulation of 1814 :

En termes plus vulgaires, beaucoup de gens ont moins acheté, parce qu'ils ont moins gagné; et ils ont moins gagné, parce qu'ils ont trouvé des difficultés dans l'emploi de leurs moyens de production, ou bien parce que ces moyens leur ont manqué.

(See above, p. 196)

7 In this context Say denied that landowners could be categorized within the category of unproductive consumers:

Whom do you [Malthus] designate by this numerous body of unproductive consumers, so necessary, according to you, to the producers? Is it the proprietors of lands and capitals? Undoubtedly they do not directly produce, but their instruments (their property) does it for them. They consume the value to the creation of which their lands and capitals have contributed. They therefore assist in production, and can only make purchases in consequence of this assistance.

(Say 1821 [1820]: 32)

8 Say goes on to point out the greater distress in labour-intensive than in capital-intensive industries:

elles sont beaucoup moins funestes là où les machines sont répandues; car enfin dans les lieux où tout se fait à bras d'hommes, si le travail vient à manquer, beaucoup d'hommes restent sans pain, tandis que lorsqu'une machine manque d'ouvrage, son propriétaire perd seulement l'intérêt du capital qu'elle représente.

(Say 1843 [1828-9]: 90)

Another indication of Say's sympathy for labour will be found in Chapter 3, note 12.

9 For the opposing view, see Sowell (1972a: 77-8; 1972b: 68-9). Sowell points to a letter from Say to Sismondi reported by the latter, 5 September 1828: 'I have had a letter from M. Say, who announces to me a second volume of his book [Cours complet], with some concessions to my principles on the limits of production' (Sismondi 1847: 449). In fact, Sowell charges Say with plagiarism, by 'repeating (without citation) Sismondi's argument that when output's "utility is not worth what it cost", such output is unsustainable" (Sowell 1987c: 350). (The offending passage is found in Say (1826a, 1: 195) - cited above (p. 123) - allegedly copied from Sismondi 1951 [1827], 1: 84-5.) Whether or not the charge is valid, the important point to note is that the focus of the chapter in question - 'Augmentation des besoins de l'homme social, et bornes de la production' - is not at all the limit imposed on production by demand constraints but that reflecting a preference for leisure rather than goods.

10 Ricardo's first formal reference to a version of the Law of Markets appears in the Appendix to The High Price of Bullion published in 1811, and asserts that while there may at any time be limits to consumption, nonetheless consumption demand together with investment demand would absorb any conceivable level of output (Ricardo 1951-73, 3: 107). The formulation is then supplemented by the condition for the smooth operation of the system - that the composition of output be suitable to the taste pattern of consumers and investors: 
[No] country ever possessed a general glut of all commodities. It is evidently impossible. If a country possesses every thing necessary for the maintenance and comfort of man, and these articles be divided in the proportions in which they are usually consumed, they are sure, however abundant, to find a market to sell them off.

(108; emphasis added)

11 That Stigler did not actually attribute to James Mill the fully fledged statement, including sale at cost-covering prices, is confirmed by his later observation regarding Commerce Defended, whereby Mill proposed that 'total output, if properly composed of various goods, could always be sold' with Ricardo adding 'at prices equal to costs' rendering it an equilibrium proposition (Stigler 1976: 64).

12 On receipt of the 1814 version Ricardo wrote to Malthus: 'Mr. Say, in the new edition of his book, Page 99 Vol. 1, supports, I think, very ably the doctrine that demand is regulated by production' (1951-73, 6: 163-4). This does not necessarily imply that he found the 1814 version preferable to that of 1803 as Forget maintains (Forget 1999: 167; 2003: 54).

13 Ricardo's elaboration contains the very important proposition that

[p]roductions are always bought by productions, or by services; money is only the medium by which the exchange is effected. Too much of a particular commodity may be produced, of which there may be such a glut in the market, as not to repay the capital expended on it; but this cannot be the case with respect to all commodities.... [N]othing is required but the means, and nothing can afford the means, but an increase of production.

(Ricardo 1951-73, 1: 291-2; emphasis added)

'Commodities' for Ricardo thus include services, and his Law of Markets must be so understood.

14 McCulloch also paid tribute to Say as 'the first who showed, in a full and satisfactory manner, that effective demand depends on production', adding the qualification that 'the principles from which his conclusions are drawn' were already to be found in Tucker (1752) (see McCulloch 1845: 21; 1864: 156n.). J. S. Mill gave equal weight to Say and James Mill:

It is but justice to two eminent names, to call attention to the fact, that the merit of having placed this most important point in its true light, belongs principally, on the Continent, to the judicious J. B. Say, and in this country to Mr. Mill; who (besides the conclusive exposition which he gave to the subject in his Elements of Political Economy) had set forth the correct doctrine with great force and clearness in an early pamphlet, called forth by a temporary controversy, and entitled 'Commerce Defended'; the first of his writings which attained any celebrity, and which he prized more as having been his first introduction to the friendship of David Ricardo, the most valued and most intimate friendship of his life.

(Mill 1963-91 [1848], 3: 576)

In 1826 Say himself cited Prinsep, who regarded Say as Ricardo's source: 'Les vues de Sismondi ... ont été adoptées par Malthus, et celles de notre auteur [Say] par Ricardo' (Say 1826a, 1: 187n.).

15 Malthus for his part agreed with Ricardo's criticism of Say and Torrens in so far as concerned 'the necessity of countercommodities in all cases' (25 September 1820; in Ricardo 1951-73, 8: 260). But while he agreed that the supply of the commodity produced in excess should be contracted, he found no assurance that the released resources would be reabsorbed in another sector 'without any other fall of profits than that which arises necessarily from the state of the land, or temporarily from the improved condition of the labouring classes'. In brief, a successful transfer of resources would require a fall in the return on capital. 


\section{Say and the classical canon: an overview}

1 Say uses the terms 'faits généraux', 'lois générales' and 'principes' interchangeably:

Les faits généraux, ou si l'on veut les lois générales [1819: que suivent les faits] [1826: Les lois générales qui règlent la marche des choses], se nomment des principes, du moment qu'il s'agit de leur application; c'est-à-dire, du moment qu'on s'en sert pour juger les circonstances qui s'offrent, et pour servir de règle à ses actions. La connaissance des principes donne seule cette marche assurée qui se dirige constamment et avec succès vers un bon but.

(1814, 1: xxix; 1817, 1: xxiii-xxiv; 1819a, 1: xxvii; 1826a, 1: xxviii-xxix)

2 In the Cours complet political economy is represented, more generally, as a 'positive' science: 'L'économie politique, comme toutes les sciences positives, examine les faits dans ce qu'ils ont été, dans ce qu'ils sont, dans leur liaison les uns avec les autres, dans la déduction logique de leurs conséquences' (Say 1843 [1828-9]: 335n.).

3 For an instance of Say's formal opposition to 'system', see below (p. 279). Magnan de Bornier and Tosi (2003) and Legris and Ragni (2003) approach the issue from the perspective of Say's case for a 'practical' political economy.

4 The 1817 version is less detailed, but still entails a mechanical analogy:

Le vendeur élève la valeur de sa chose aussi haut, et l'acheteur la baisse aussi bas qu'ils le peuvent l'un et l'autre. Or, le vendeur peut d'autant plus élever la valeur de la chose, qu'elle est moins commune et plus recherchée; et l'acheteur peut d'autant plus l'abaisser, que la chose est plus abondante et moins demandée: le point où leurs deux efforts se balancent, est celui où se fixe la valeur de la chose. C'est ce qu'on exprime par cette formule, que la valeur des choses est toujours en raison directe de la quantité demandée, et en raison inverse de la quantité offerte, de chaque chose, en chaque lieu.

(Say 1817, 2: 7-8; cf. 1814, 2: 4)

5 Other examples of methodological objections to Ricardo's 'over-simplification' relate to tax incidence, the uniformity of returns, the subsistence wage, and the strict dependency of output on capital.

6 See also Steiner (1990; 1998b: 238).

7 In principle, the differential returns to entrepreneurship might be incorporated into the competitive framework by application of differential-rent logic. As for entrepreneurs who fail, Say seems to have in mind a built-in defence mechanism which minimizes the social damage, thus somewhat playing down the matter. This emerges in a discussion of failure to adopt best techniques, though Say generalizes:

Mais aussi, et par cette raison même, ceux qui ne savent pas user aussi économiquement que les autres, des moyens de production, perdent où les autres gagnent. Que de manufacturiers se sont ruinés, parce qu'ils ne savaient travailler qu’à grands frais dans des bâtimens fastueux, et avec des outils trop multipliés ou trop chers, et par conséquent avec des capitaux trop considérables! [1826: plus considérables que ceux qu'employaient d'autres manufacturiers, pour ne pas obtenir plus de produits!]

[1814: On en peut dire autant de l'entrepreneur, qui pour sa dépense personnelle, consomme plus que la nature de son entreprise ne rapporte communément pour les profits d'une telle industrie. Il faut bien alors que ces consommations trop fortes soient prises sur les capitaux de l'entreprise qu'elles altèrent graduellement et progressivement, au grand préjudice des entrepreneurs eux-mêmes, des créanciers de l'entreprise et de la société en général.]

Heureusement que l'intérêt personnel est, dans la plupart des cas, le premier et le plus vivement affecté de ces pertes. C'est ainsi que la douleur avertit nos 
membres des lésions dont il faut qu'ils se garantissent. Si le producteur maladroit n'était pas le premier puni des pertes dont il est l'auteur, nous verrions bien plus souvent encore risquer de fausses speculations.

$$
\begin{array}{r}
(1814,2: 190-1 ; 1817,2: 200 ; 1819 a, 2: \\
230 ; 1826 a, 3: 23-4)
\end{array}
$$

8 This passage raises the potential for entrepreneurial mobility across industries, a grey area in Sayian economics.

\section{Conclusion}

1 Say draws support for the facts of the case from statistical data: 'd'après tous les relevés statistiques que j'ai pu consulter, jusqu'à la première année de ce siècle, l'Angleterre, année commune, a constamment exporté du blé; et depuis lors, elle en a constamment importé' (Say 1819b, 1: 373); and also from the legislative implications:

J'en juge encore sur la législation actuelle de ce pays, où les douanes sont armées contre l'importation du blé, et où l'exportation est libre, assuré que l'on est qu'on n'exportera pas du grain d'un pays où il manque constamment, et où il est par conséquent plus cher que partout ailleurs.

2 For an elaboration, see Say's 'De l'Angleterre et des Anglais' (1848 [1815]: 212-13, 219-20, 222). Say mentions briefly the landlords' concern with the threat of free trade 'on abandonnera l'exploitation des terres médiocres' (221) - but plays down the corn component in the working-class budget.

3 But Say was generally hostile towards Condillac as too much under physiocratic influence from a methodological stance (1826a, 1: liv-lv).

4 The 1817 and 1819 editions refer also to Say's own De l'Angleterre et des Anglais on the essential principle of money-supply limitation.

5 If there was change in the monetary context, it was not carried out systematically. We find the original positive attitude in the 'Discours préliminaire' of 1826; and there is a new favourable reference in the text to Ricardo's position $(1951-73,1: 249)$ that the British Sinking Fund was 'only such in name' (Say 1826a, 3: 252).

6 The editor of the Encyclopédie Progressive makes a point of insisting on the journal's neutrality between the contending 'schools' of Ricardo, Malthus and Say: 'Nous n'entendons exclure de l'Encyclopédie progressive aucune école; nous espérons que chacune y exposera ses idées par l'organe de ses plus illustres interprètes' (in Say 1826b: 217n.).

7 Say refers to the Constancio translation of the Principles containing his Notes. He evidently had not turned his back on the latter.

8 Say includes the outrageous charge that Ricardo represented land as 'unproductive' (Say 1825: 705-6). He is on safer ground when he complains of the Ricardian neglect of 'entrepreneurship' (712).

9 On Say's decision not to publish, see Sraffa in Ricardo (1951-73, 6: xxvi-xxvii). Writing to Tooke on 14 May 1826: 'Je me suis convaincu moi-même que le moment, tout au moins, était fort peu propre à une semblable publication' (Say 1848: 526; letter misdated 1825). In correspondence with Place, 18 January 1826, Say expresses his concern: 'What will Ricardo's family think of the publication?' But this seems to relate not to substance, but to disappointment with the quality of Place's specimen translations. For more on this issue see Steiner (1998b: 236).

10 McCulloch expressed the same negative opinion, in yet stronger terms, after Say's death with respect to the 1826 version:

This work would deserve to be respectfully mentioned, were it only for the influence which it has had in diffusing a knowledge of the true principles with respect to the production of wealth and the freedom of industry throughout the Continent. 
It is well arranged, clearly written, and easily understood. But, except in so far as respects the inquiry relating to gluts, Say has left the science in precisely the same state in which he received it from Adam Smith. He appears, indeed, to have taken the limits of his own vision for those of the horizon, and to have supposed that the science had attained in his hands to its highest possible perfection! It is difficult otherwise to account for his obstinately refusing to profit by the important discoveries of Ricardo and others. The first edition of his work, published in 1802 [sic], is in fact nearly as good as the last edition, published in 1826; though all that great branch of the science which treats of the distribution of wealth and the principles of taxation had been completely changed in the interim. The distinguishing merit of Say is that of a skilful exponent of truths and principles already known and fully established. Whatever seemed to open new views, or to clash in any degree with doctrines to which he had already assented, was sure, how well soever it might be established, to encounter his hostility.

His principal merit in a scientific point of view consists in his showing, in a more satisfactory manner than it had been done previously, that effective demand depends upon production.

(McCulloch 1845: 21)

This opinion is belied to some extent by the use McCulloch actually made of Say's work with respect inter alia to the measure of the gain from trade, and emphasis on invention in place of Smithian division of labour (see O'Brien, 1970: 197-8; 277). There is too the methodological dimension (see Appendix II).

11 I have encountered only one instance when Say hints at disingenuousness on the part of Ricardo himself. It relates to Ricardo's charge against him of self-contradiction, in defining riches sometimes in value terms, sometimes in product terms (above, p. 72).

12 For another instance of sensitivity to criticism from across the Channel, see Walker on Walras (Walker 1996: 422-3).

13 One modification to the letters relates to the population principle. In a postscript to the letter actually sent dated 19 July 1821, Say complains that reactions to his Lettres à M. Malthus reflected misunderstanding and misrepresentation of his true position which he wished to have conveyed to Malthus:

J'ai vu avec peine que plusieurs des écrivains Anglais qui ont fait mention de mes Lettres à Malthus, outre qu'ils n'ont pas toujours rendu fidèlement mon sens, ont interprété ironiquement les éloges que je donne à l'illustre auteur de l'Essai sur la population. Comme vous le voyez quelquefois, ayez la bonté de lui dire que les témoignages de mon admiration pour son premier ouvrage, sont la fidèle expression des sentimens que je professe et qui ne peuvent être altérés par les discussions où nous sommes entrés sur des questions d'Economie politique. J'ai lu les principaux écrits où l'on a attaqué sa doctrine de la population, et je serais bien aise qu'il sût qu'ils n'ont ébranlé en rien l'estime que je fais et de la doctrine, et du livre, et de son respectable auteur.

(Say, in Ricardo 1951-73, 9: 36)

The reformulated version of 1825 is similar, except for the close which waters down the commendation of the Essay on Population:

J'ai lu les principaux écrits où l'on a attaqué ses principes sur la population (qui ne sont au reste que l'opinion développée de presque tous les publicistes sur cette matière), et je serais bien aise qu'il sût que toutes ces attaques n'ont en rien ébranlé l'estime que j'ai conçue pour le livre et pour l'auteur. 
14 This comes as something as a surprise considering that, a short while earlier (14 May 1825), Say had written to Tooke that the latter's Thoughts and Details (1824) provided the key to the interpretation of British crisis conditions, making no mention of Ricardo and, to the contrary, taking the opportunity to condemn Ricardian method and to champion a practical political economy:

Il m’a expliqué plusieurs circonstances de la détresse commerciale que l'Angleterre a éprouvée dernièrement, et qui, ainsi que vous l'observez justement, doit faire naître de graves réflexions sur le système entier de sa circulation monétaire (of her currency). Toutes vos observations sont fondées sur des faits, et toutes sont applicables aux besoins de la société. Cette philosophie pratique est bien supérieure à la métaphysique obscure à laquelle plusieurs de vos compatriotes voudraient réduire les questions économiques. En fondant leurs arguments sur des principes abstraits plutôt que sur des faits observés, ils arrivent à des conséquences tout à fait différentes des résultats de l'expérience. Rien n'est plus propre à décréditer l'économie politique, que de faire croire qu'elle n'est bonne qu'à faire naître des discussions ennuyeuses d'où il ne résulte que des indications fausses. Après avoir lu votre livre, au contraire, il n'y a point de négociant, de directeur de la Banque et de ministre d'État qui ne soit forcé de convenir qu'il lui a suggéré des idées utiles, et propres à prévenir le retour des inconvénients passés.

(Say 1848: 525-6)

15 To this is attached a wholly disparaging footnote:

Les observations de David Ricardo ... sur les revenus des biens-fonds, se trouvent dans Adam Smith; et, quant aux conséquences qu'il en tire, il est permis de les contester. Dans sa doctrine sur l'impôt, il fonde ses résultats sur des abstractions, et abandonne la méthode expérimentale. 


\section{Bibliography}

Anon. (1820) A Reply to Mr. Say's Letters to Mr. Malthus on the Subject of the Stagnation of Trade, London: J. M. Richardson.

Arena, R. (2001a) 'J.-B. Say and the French Liberal School of the nineteenth century: outside the Canon?', in E. L. Forget and S. Peart (eds), Reflecting on the Canon in Economics, London: Routledge, pp. 205-23.

(2001b) 'French views on the existence of an "English" Classical School: an interpretation', Version provisoire, présentée au Colloque LATAPSES-IODE: 'British and Continental Traditions on Classical Political Economy', Sophia Antipolis, 13-14 December 2001.

- (2003) 'La loi de l'offre et de la demande chez Jean-Baptiste Say: une interprétation', in J.-P. Potier and A. Tiran (eds), Jean-Baptiste Say: nouveaux regards sur son oeuvre, Paris: Economica, pp. 303-24.

Bailey, Samuel (1825) A Critical Dissertation on the Nature, Measure and Causes of Value, London: R. Hunter.

Baumol, W. J. (1977) 'Say's (at least) eight laws, or what Say and James Mill may really have meant', Economica 44: 145-62.

- (1997) 'J.-B. Say on unemployment and public works', Eastern Economic Journal 23: 219-31.

- (2003) 'Retrospectives: Say's Law', in S. Kates (ed.), Two Hundred Years of Say's Law: essays on economic theory's most controversial principle, Cheltenham: Edward Elgar, pp. 39-49.

Boss, H. (1990) Theories of Surplus and Transfer: Parasites and Producers in Economic Thought, Boston: Unwin Hyman.

Buchanan, David (1814) Observations on the Subjects Treated of in Dr. Smith's Inquiry into the Nature and Causes of the Wealth of Nations, Edinburgh: Oliphant, Waugh \& Innes.

Cantillon, Richard (1931 [1755]) Essai sur la Nature du Commerce en Général, ed. H. Higgs, London: Macmillan.

Chipman, J. S. (1965) 'A survey of the theory of international trade: Part 2. The Neo-classical theory', Econometrica 33: 685-760.

Corry, B. (1962) Money, Saving and Investment in English Economics, 1800-1850, London: Macmillan.

Davis, T. (2003) 'The historical context of the General Glut controversy', in S. Kates (ed.), Two Hundred Years of Say's Law: essays on economic theory's most controversial principle, Cheltenham: Edward Elgar, pp. 133-53.

- (2005) Ricardo's Macro Economics: money, trade cycles and growth, Cambridge: Cambridge University Press. 


\section{Bibliography}

Diemer, A. (2003) 'Utilité, valeur, demande: la controverse entre Jean-Baptiste Say et Jules Dupuit', in J.-P. Potier and A. Tiran (eds), Jean-Baptiste Say: nouveaux regards sur son oeuvre, Paris: Economica, pp. 361-79.

Dunbar, C. F. (1886-7) 'Ricardo's use of facts', Quarterly Journal of Economics 1: 474-6.

Dupuit, Jules (1933 [1849]) 'De l'influence des péages', in De l'utilité et de sa mesure: écrits choisis et republiés, ed. Mario de Bernardi, Turin: La Riforma Sociale, pp. 97-162.

— (1933 [1853]) 'De l'utilité et de sa mesure', in De l'utilité et de sa mesure: écrits choisis et republiés, ed. Mario de Bernardi, Turin: La Riforma Sociale, pp. 163-81.

Eagly, R. V. (1974) The Structure of Classical Economic Theory, New York: Oxford University Press.

Ekelund, R. B. and Thornton, M. (1991) 'Geometric analogies and market demand estimation: Dupuit and the French contribution', History of Political Economy 23: 397-418.

Eltis, W. (2001) 'The French foundation of the classical canon', in E. L. Forget and S. Peart (eds), Reflecting on the Canon in Economics, London: Routledge, pp. 185-204.

Forget, E. L. (1999) The Social Economics of Jean-Baptiste Say: markets and virtue, London: Routledge.

- (2003) 'Jean-Baptiste Say and the Law of Markets: entrepreneurial decision-making in the real world', in S. Kates (ed.), Two Hundred Years of Say's Law: essays on economic theory's most controversial principle, Cheltenham: Edward Elgar, pp. 50-66.

Forget, E. L. and Peart, S. (eds) (2001) Reflecting on the Canon in Economics, London: Routledge.

Garnier, Germain (1796) Abrégé Élémentaire des Principes Économiques, Paris: H. Agasse.

Gehrke, C. and Kurz, H. D. (2001) 'Say and Ricardo on value and distribution', European Journal of the History of Economic Thought 8: 449-86.

- (2003) 'Say et Ricardo', in J.-P. Potier and A. Tiran (eds), Jean-Baptiste Say: nouveaux regards sur son oeuvre, Paris: Economica, pp. 215-63.

Gootzeit, M. (2003) 'Say ou comment le risque a séparé l'entrepreneur du capitaliste', in J.-P. Potier and A. Tiran (eds), Jean-Baptiste Say: nouveaux regards sur son oeuvre, Paris: Economica, pp. 555-75.

Hayek, F. (1941) ' "Demand for Commodities is Not Demand for Labour" versus the doctrine of "Derived Demand", The Pure Theory of Capital, Chicago: University of Chicago Press, Appendix III, pp. 433-9.

Hébert, R. F. and Link, A. N. (1982) The Entrepreneur: mainstream views and radical critiques, New York: Praeger.

Heertje, A. (1971) 'Two letters from James Mill to Jean-Baptiste Say', History of Political Economy 3: 416-8.

Hennings, K. H. (1980) 'The transition from classical to neoclassical economic theory: Hans von Mangoldt', Kyklos 33: 658-81.

Hollander, J. H. (1910) David Ricardo: A Centenary Estimate, Baltimore, MD: The Johns Hopkins University Press.

_ (1928) Introduction to David Ricardo, in J. H. Hollander and T. E. Gregory (eds), Notes on Malthus's Principles of Political Economy, Baltimore, MD: The Johns Hopkins University Press, pp. ix-cvi.

Hollander, S. (1979) The Economics of David Ricardo, Toronto: University of Toronto Press. (1982) 'On the substantive identity of the Ricardian and neo-classical conceptions of economic organization: the French connection in British Classicism', Canadian Journal of Economics 15: 586-612; also in S. Hollander (1995) Ricardo. The 'New View': Collected Essays I, London and New York: Routledge, pp. 135-66.

_ (1985) The Economics of John Stuart Mill, Toronto: University of Toronto Press. (1992) Classical Economics, Toronto: University of Toronto Press. (1997) The Economics of Thomas Robert Malthus, Toronto: University of Toronto Press. 
(1998a) 'The canonical classical growth model: content, adherence and priority', Journal of the History of Economic Thought 19: 253-77.

(1998b) 'The Corn-Law pamphlet literature of 1815: Malthus, West, Ricardo and Torrens', in The Literature of Political Economy: Collected Essays III, London, Routledge, pp. 193-243.

(2000) 'Sraffa and the interpretation of Ricardo: the Marxian dimension', History of Political Economy 32: 187-232.

- (2001) '“Classical Economics": a reification wrapped in an enigma?', in E. L. Forget and S. Peart (eds), Reflecting on the Canon in Economics, London: Routledge, pp. 7-26.

Hollander, S. and Peart, S. (1999) 'J. S. Mill's method in principle and practice: a review of the evidence', Journal of the History of Economic Thought 20: 369-98.

Jevons, W. S. (1879) Theory of Political Economy, 2nd edn, London: Macmillan.

Johnson, H. (1949) 'Demand for commodities is not demand for labour', Economic Journal 59: $531-6$.

Jonsson, P. O. (1977) 'On gluts, effective demand and the meaning of Say's Law', Eastern Economic Journal 23: 203-18.

Kates, S. (1997) 'On the true meaning of Say's Law', Eastern Economic Journal 23: 191-202.

(ed.) (2003) Two Hundred Years of Say's Law: essays on economic theory's most controversial principle, Cheltenham: Edward Elgar.

Knight, F. (1964 [1921]) Risk, Uncertainty and Profit, New York: Augustus M. Kelley.

Koolman, G. (1971) 'Say's conception of the role of the entrepreneur', Economica 38: 269-86.

Lambert, P. (1956) 'The Law of Markets prior to J. B. Say and the Say-Malthus debate', International Economic Papers 6: 7-22.

Lange, O. R. (1942) 'Say's Law: a criticism and restatement', in O. Lange, F. McIntyre and T. O. Yntema (eds), Studies in Mathematical Economics and Econometrics, Chicago: University of Chicago Press, pp. 49-68.

Lauderdale, Lord (1804) An Inquiry into the Nature and Origin of Public Wealth and into the Means and Causes of its Increase, 1 st edn, Edinburgh: Constable.

Legris, A. and Ragni, L. (2003) 'La conception de l'individu chez Jean-Baptiste Say', in J.-P. Potier and A. Tiran (eds), Jean-Baptiste Say: nouveaux regards sur son oeuvre, Paris: Economica, pp. 41-68.

Leontief, W. (1971) 'Theoretical assumptions and nonobserved facts', American Economic Review 61: 1-7.

Magnan de Bornier, J. and Tosi, G. (2003) 'La méthode de Jean-Baptiste Say: au service d’une discipline autonome', in J.-P. Potier and A. Tiran (eds), Jean-Baptiste Say: nouveaux regards sur son oeuvre, Paris: Economica, pp. 44-68.

Mahieu, F.-R. (1992) 'Présentation', in David Ricardo, Des Principes de l'Économie Politique et de l'Impôt, Paris: Flammarion., pp. 19-41.

Malthus, T. R. (1817) An Essay on the Principle of Population, London: John Murray.

- (1820) Principles of Political Economy, considered with a view to their practical application, 1st edn, London: John Murray. - (1827a) House of Commons Parliamentary Papers. Third Report from the Select Committee on Emigration (550) V. Evidence, 5 May, pp. 311-27.

(1836) Principles of Political Economy, considered with a view to their practical application, 2nd edn, London: William Pickering.

- (1986) The Works of Thomas Robert Malthus, London: William Pickering.

(1986 [1815]) An Inquiry into the Nature and Progress of Rent, in The Works of Thomas Robert Malthus, London: William Pickering, 7: 115-45.

- (1986 [1823]) The Measure of Value, Stated and Illustrated, in The Works of Thomas Robert Maltbus, London: William Pickering, 7: 179-253. 


\section{Bibliography}

(1986 [1824]) 'On political economy', in The Works of Thomas Robert Malthus, London:

William Pickering, 7: 257-97.

(1986 [1827b]) 'On the meaning which is most usually and most correctly attached to the term value of a commodity', in The Works of Thomas Robert Malthus, London: William Pickering, 7: 315-23.

— (1986 [1827c]) Definitions in Political Economy, in The Works of Thomas Robert Malthus, London: William Pickering, 8.

Marshall, Alfred (1920) Principles of Economics, 8th edn, London: Macmillan.

McCulloch, John Ramsay (1821) Review of Say 1821 [1819a], Scotsman 21 April: 126.

- (1824) House of Commons Parliamentary Papers. Select Committee on Artisans and Machinery (51), V. Evidence, pp. 592-8.

- (1825 [1823]) Outlines of Political Economy; being a republication of the article upon that subject contained in the Edinburgh Supplement to the Encyclopedia Britannica, ed. John McVicker, New York: Wilder \& Campbell.

- (1825a) The Principles of Political Economy with a Sketch of the Rise and Progress of the Science, 1st edn, Edinburgh: W. and C. Tait.

- (1825b) A Discourse on the Rise, Progress, Peculiar Objects and Importance of Political Economy, 2nd edn, Edinburgh: Constable.

- (1828) Adam Smith, An Inquiry into the Nature and Causes of the Wealth of Nations ...

With a life of the author, an introductory discourse, notes, and supplementary dissertations, by

J. R. McCulloch, Edinburgh: A. Black and W. Tait.

- (1845) The Literature of Political Economy: a classified catalogue, London: Longman, Brown, Green, and Longmans.

- (1864) The Principles of Political Economy, with some inquiries respecting their application, 5th edn, Edinburgh: Adam and Charles Black.

Mill, James (1804) 'Lord Lauderdale on public wealth', The Literary Journal 4: 3-18.

— (1805) 'Say's Traitê, The Literary Journal 5: 412-25.

(1808) Commerce Defended, London: C. and R. Baldwin.

(1821) Elements of Political Economy, 1st edn, London: Baldwin, Cradock and Joy.

(1966) Selected Economic Writings, ed. Donald Winch, Edinburgh and London: Oliver and Boyd.

Mill, J. S. (1963-91 [1828]) 'The nature, origin and progress of rent', Collected Works, ed.

J. M. Robson, Toronto: University of Toronto Press, 4: 161-80.

(1963-91 [1843]) A System of Logic Ratiocinative and Inductive, Collected Works, vols 7 and 8, ed. J. M. Robson, Toronto: University of Toronto Press.

- (1963-91 [1844]) 'Of the influence of consumption on production', Collected Works, ed.

J. M. Robson, Toronto: University of Toronto Press, 4: 262-79.

- (1963-91 [1848]) Principles of Political Economy, Collected Works, vols 2 and 3, ed.

J. M. Robson, Toronto: University of Toronto Press.

O'Brien, D. P. (1970) J. R. McCulloch: a study in Classical Economics, London: George Allen and Unwin.

- (1988) 'Classical reassessments', in W. O. Thweatt (ed.), Classical Political Economy: a survey of recent literature, Boston: Kluwer, pp. 179-220.

- (2001) Review of Forget 1999, History of Political Economy 33: 381-2.

(2003) 'Classical Economics', in W. J. Samuels, J. E. Biddle and J. B. Davis (eds), A Companion to the History of Economic Thought, Oxford: Blackwell, pp. 112-29.

O'Brien, D. P. and Darnell, A. C. (1982) Authorship Puzzles in the History of Economics: a statistical approach, London: Macmillan. 
Palmer, R. R. (1997) J.-B. Say, An Economist in Troubled Times, Princeton, NJ: Princeton University Press.

Peach, T. (1993) Interpreting Ricardo, Cambridge: Cambridge University Press.

Potier, J.-P. (2003) 'Quelques remarques sur l'évolution des idées de Jean-Baptiste Say au sujet de la valeur et du prix', in J.-P. Potier and A. Tiran (eds), Jean-Baptiste Say: nouveaux regards sur son oeuvre, Paris: Economica, pp. 283-301.

Potier, J.-P. and Tiran, A. (eds) (2003) Jean-Baptiste Say: nouveaux regards sur son oeuvre, Paris: Economica.

Pullen, J. (1989) 'Introduction' to the Variorum Edition of T. R. Malthus, Principles of Political Economy, Cambridge: Cambridge University Press, 1: xv-lxix.

Ravix, J. T. and Spindler, J. (2003) 'Richesse et luxe chez Jean-Baptiste Say', in J.-P. Potier and A. Tiran (eds), Jean-Baptiste Say: nouveaux regards sur son oeuvre, Paris: Economica, pp. 381-400.

Ricardo, David (1819) Des Principes de l'Économie Politique et de l'Impôt . . traduit de l'anglais par F. S. Constancio . . avec des notes explicatives et critiques par Jean-Baptiste Say, Paris: J. P. Aillard. - (1835 [1819]) Des Principes de l'Économie Politique et de l'Impôt . . . traduit de l'anglais par F. S. Constancio ... avec des notes explicatives et critiques par Jean-Baptiste Say, Brussels: H. Dumont.

(1882 [1819]) Des Principes de l'Économie Politique et de l'Impôt, in Oeuvres Complètes, traduites en français par [F. S.] Constancio et [A.] Fonteyraud, Paris: Guillaumin.

— (1951-73) Works and Correspondence, ed. Piero Sraffa, Cambridge: Cambridge University Press.

— (1992 [1821]) Des Principes de l'Économie Politique et de l'Impôt, Paris: Flammarion.

Robinson, J. (1961) 'Prelude to a Critique of Economic Theory', Oxford Economics Papers 13: 53-8.

Samuelson, P. A. (1978) 'The canonical classical model of political economy', Journal of Economic Literature 16: 1415-34.

Say, Jean-Baptiste (1803) Traité d'Économie Politique ou Simple Exposition de la Manière dont se Forment, se Distribuent, et se Consomment les Richesses, 1st edn, Paris: Déterville.

(1814) Traité d'Économie Politique, 2nd edn, Paris: Renouard.

(1815) Catéchisme d'Économie Politique ou Instruction Familière, qui montre de quelle manière

les richesses sont produites, distribuées et consommées, 1st edn, Paris: Dechaunay Libraire au

Palais Royal.

- (1817) Traité d'Économie Politique, 3rd edn, Paris: Déterville.

- (1819a) Traité d'Économie Politique, 4th edn, Paris: Déterville.

(1819b) Notes Explicatives et Critiques, to Ricardo 1819.

(1821 [1819a]) A Treatise on Political Economy; or, The Production, Distribution, and

Consumption of Wealth, translated from the fourth edition of the French, by C. R. Prinsep,

London: Longman.

- (1821 [1820]) Letters to Mr. Malthus on Several Subjects of Political Economy and on the Cause of the Stagnation of Commerce, translated from the French by John Richter, 1st edn, London: Sherwood, Neely \& Jones.

_- (1822) Catéchisme d'Économie Politique, 2nd edn, Paris: Bossange.

(1825) 'Économie politique' (review of McCulloch 1825b), Revue Encyclopédique 27:

694-719.

- (1826a) Traité d'Économie Politique, 5th edn, Paris: Rapilly.

(1826b) 'Économie politique', Encyclopédie Progressive 1: 217-304.

(1826c) 'De la crise commerciale de l'Angleterre' (prepublication review of Sismondi 1827), Revue Encyclopédique 32: 40-5.

- (1827a) Review of Malthus 1986 [1827c], Revue Encyclopédique 30: 494-6.

(1827b) 'De l'objet et de l'utilité des statistiques', Revue Encyclopédique 35: 529-53. 


\section{Bibliography}

(1843 [1828-9]) Cours Complet d'Économie Politique Pratique: ouvrage destine à mettre sous les yeux des bommes d'état, des propriétaires fonciers et des capitalistes, des savants, des agriculteurs, des manufacturiers, des négociants, et en général de tous les citoyens, l'économie des sociétés ('sixième édition entièrement revue par l'auteur'), ed. Horace Say, Brussels: Société Typographique Belge, pp. 1-578.

_- (1843) Mélange et Correspondance d'Économie Politique, publié par Charles Comte, Brussels: Société Typographique Belge, pp. 579-681.

_ (1848) Oeuvres Diverses, ed. C. Comte, E. Daire and H. Say, Paris: Guillaumin.

- (1848 [1815]) 'De l'Angleterre et des Anglais', in C. Comte, E. Daire and H. Say (eds), Oeuvres Diverses, Paris: Guillaumin, pp. 205-31.

- (1848 [1823]) 'Notes explicatives et critiques' to Storch 1823, in C. Comte, E. Daire and H. Say (eds), Oeuvres Diverses, Paris: Guillaumin, pp. 285-341.

- (1848 [1824]) 'Sur la balance des consummations avec les productions', in C. Comte,

E. Daire and H. Say (eds), Oeuvres Diverses, Paris: Guillaumin, pp. 250-60.

- (1880 [1819a]) A Treatise on Political Economy or the Production, Distribution, and Consumption of Wealth, translated from the fourth edition of the French, by C. R. Prinsep, Philadelphia: Claxton, Remsen \& Haffelfinger.

- (1996 [1819]) Cours à l'Athénée, in P. Steiner (ed), Cours d'Économie Politique et d'autres essais, Paris: GF-Flammarion, pp. 81-217.

Say, Louis (1818) Principales Causes de la Richesse ou de la Misère des Peuples et des Particuliers,

Paris: Aïllaud.

—_ (1822) Considérations sur l'Industrie et la Législation, sous le Rapport de leur Influence sur la

Richesse des États, et Examen Critique des Principaux Ouvrages qui ont paru sur l'Économie Politique, Paris: Aillaud.

Schoorl, E. (1980) J.-B. Say, Amsterdam: Coöp. Drukkerij.

Schumpeter, J. A. (1954) History of Economic Analysis, New York: Oxford University Press.

Sismondi, J. C. L. Simonde de (1819) Nouveaux Principes d'Économie Politique, Paris: Delaunay. (1847) Political Economy and the Philosophy of Government; selected essays and illustrated

by extracts from ... M. de Sismondi's private journals and letters, translated from the French, London: John Chapman.

—_ (1951 [1827]) Nouveaux Principes d'Économie Politique, 2nd edn, ed. G. Sotiroff, Geneva: Jehebes.

Smith, Adam (1937 [1776]) The Wealth of Nations, New York: Modern Library.

Smith, V. E. (1951) 'The Classicists' use of "demand"', Journal of Political Economy 59: $242-57$.

Soliani, R. (2003) 'L'évolution de la théorie de la valeur et de la répartition de Jean-Baptiste Say et la relation qu'elle a avec la tradition classique', in J.-P. Potier and A. Tiran (eds), Jean-Baptiste Say: nouveaux regards sur son oeuvre, Paris: Economica, pp. 265-82.

Sowell, T. (1972a) Say's Law: An Historical Analysis, Princeton, NJ: Princeton University Press.

- (1972b) 'Sismondi: a neglected pioneer', History of Political Economy 4: 62-89.

(1974) Classical Economics Reconsidered, Princeton, NJ: Princeton University Press.

- (1987a) 'Say, Jean-Baptiste 1767-1832', in John Eatwell, Murray Milgate and Peter

Newman (eds), The New Palgrave: A Dictionary of Economics, London and Basingstoke:

Macmillan, 4: 249.

(1987b) 'Say's Law', in John Eatwell, Murray Milgate and Peter Newman (eds), The

New Palgrave: A Dictionary of Economics, London and Basingstoke: Macmillan, 4: 249-51.

_ (1987c) 'Sismondi', in John Eatwell, Murray Milgate and Peter Newman (eds), The

New Palgrave: A Dictionary of Economics, London and Basingstoke: Macmillan, 4: 348-50. 
Spence, William (1807) Britain Independent of Commerce, 2nd edn, London: W. Davis and T. Cadell.

Spengler, J. J. (1960 [1945]) 'The physiocrats and Say’s Law of Markets', in J. J. Spengler and W. R. Allen (eds), Essays in Economic Thought: Aristotle to Marshall, Chicago: Rand McNally, pp. 161-214.

Steiner, P. (1990) 'L'économie politique pratique contre les systèmes: quelques remarques sur la méthode de J.-B. Say', Revue d'Économie Politique 100: 664-87.

- (1998a) 'Jean-Baptiste Say: the entrepreneur, the free trade doctrine and the theory of income distribution', in G. Faccarello (ed.), Studies in the History of French Political Economy: From Bodin to Walras, London: Routledge, pp. 196-228.

(1998b) 'The structure of Say's economic writings', European Journal of the History of Economic Thought 5: 227-49.

(1998c) 'Say, Jean-Baptiste', in H. D. Kurz and N. Salvadori (eds), The Elgar Companion to Classical Economics, Cheltenham: Edward Elgar, 2: 335-40.

- (1999) 'J.-B. Say and the political economy of his time: a quantitative approach', Journal of the History of Economic Thought 21: 349-68.

(2003) 'La production des richesses: les leçons du débat avec Ricardo', in J.-P. Potier and A. Tiran (eds), Jean-Baptiste Say: nouveaux regards sur son oeuvre, Paris: Economica, pp. 325-60.

Stigler, G. J. (1965) Essays in the History of Economics, Chicago: University of Chicago Press.

_ (1976) 'The scientific uses of scientific biography', in J. M. Robson and M. Laine (eds), James and John Stuart Mill: papers of the centenary conference, Toronto: University of Toronto Press, pp. 55-66.

Storch, Henry (1815) Cours d'Économie Politique: ou exposition des principes qui déterminent la prospérité des nations, St Petersburg: A. Pluchart.

—_ (1823) Cours d'Économie Politique: ou exposition des principes qui déterminent la prospérité des nations, Paris: Bossange \& Aïllaud.

Theocharis, R. D. (1983) Early Developments in Mathematical Economics, 2nd edn, London: Macmillan.

Thornton, Henry (1802) An Enquiry into the Nature and Effects of the Paper Credit of Great Britain, London: J. Hatchard.

Thweatt, W. O. (1979) 'Early formulators of "Say's" Law of Markets', Quarterly Review of Economics and Business 19: 79-96.

(1980) 'Baumol and James Mill on "Say's” Law of Markets', Economica 47: 467-9.

Tooke, Thomas (1824) Thoughts and Details on the High and Low Prices of the Thirty Years, from 1793 to 1822, 2nd edn, London: John Murray.

Torrens, Robert (1819) 'Mr. Owen's plans for relieving the National Distress', Edinburgh Review 32: 453-77.

Turgot, A. R. J. (1997 [1766]) Formation et Distribution des Richesses, ed. J.-T. Ravix and P.-M. Romani, Paris: Flammarion.

Walker, D. A. (1996) Walras's Market Models, Cambridge: Cambridge University Press.

Walras, Léon (1954 [1874]) Elements of Pure Economics, ed. W. Jaffe, London: Allen and Unwin.

Waterman, A. M. C. (1991) Revolution, Economics, and Religion: Christian Political Economy, 1798-1833, Cambridge: Cambridge University Press.

Winch, D. (1966) Introduction to James Mill, Selected Economic Writings, ed. Donald Winch, Edinburgh and London: Oliver and Boyd, pp. 1-38. 


\section{Index}

agriculture 11-12, 24, 39, 45, 54-5, 259; see also growth theory; rent

Anderson, James 141, 272

applied economics 236-7, 241-4, 247-8

Arena, Richard 19-20, 249

Arrow, Kenneth 13

Bacon, Francis 233

Bailey, Samuel 13, 280-1

Bank of England 209

Baumol, W. J. 21, 195, 204, 213

Bentham, Jeremy 288

Boss, H. 172

Broglie, Duc de 277

Buchanan, David 51, 264

Buffon, Georges 290

Cairnes, J. E. 13

canonical growth model 1-2, 125, 241-2, 254-8, 263; see also growth theory

Cantillon, R. 20-1

capital accumulation 7, 10, 109-10, 129, $135,170-6,183,254$

Chalmers, T. 13, 227

Chipman, J. S. 22, 224-5, 264

circular flow 135, 175, 203-4

'competition of capitals' doctrine 10-11, 24, 64-6, 109, 128, 212, 223-4, 245, 258-9, 263

Condillac, Etienne de 16, 19, 268

Condorcet, Marquis de 290

Constancio, F. S. 30, 202, 285-6

consumer surplus 99-100, 237; see also marginal conditions

consumption, productive and unproductive 170-6, 254 corn, as measure of value $43-5,51$,

$$
141-2
$$

corn laws 10, 14, 183, 264-6

corn price 10, 12, 43, 250-1, 259

cost price $13,17-19,25-46,57,58,62-3$, 75-83, 84-5, 86-96, 105, 116, 135,

178, 268; see also 'natural' price; rent;

services doctrine; value theory

counter-commodities 196-202, 206-9, 212, 224-5

Courcelle-Seneuil, J. G. 21

Darnell, A. C. 287

Davis, T. 23

deductive methodology 239-44, 248-9, 266-7

demand theory see utility

depression, industrial 12, 197-200, 203-12, $225,246,253-4$

Destutt de Tracy, A. L. C. 288

Diemer, A. 20

differential rent see rent

diminishing returns $119,125-7,135-6$, 138-9, 254-5; see also rent

Dunbar, C. F. 23

Dupuit, Jules 98, 100, 148

earnings structure see wage differentials Encyclopédie Progressive 233-4, 270

endogenous margin $6,33,55-6,75,85$, 119, 131-4, 136, 138-41, 259, 263,

270, 272; see also growth theory; rent entrepreneurship 20-2, 110-18, 179, 215-18, 251-4

equilibration $62,87-8,101,237,247$; see also marginal conditions 
equilibrium, partial and general $11,17,22$, 63

excess commodity supply 190-203, 206-8, 221, 224, 253-4

exchange value see value theory

expectations 193, 195, 225, 244

forecasting $238,241-2$

Forget, E. L. 19-20, 22, 26, 33, 184, 213-18, 234

'French tradition' in economics 15-16

free goods 157, 160, 186

free trade see gains from trade; protection

gains from trade 14-15, 184-5, 260-1, 263, 264-5

Galiani, Ferdinand 19

Garnier, Germain 102, 134, 277

Gehrke, C. 15, 19

Gootzeit, M. 110

gross and net product see surplus

Grote, Mrs George 119, 133

growth theory, land-based 1-2, 10, 12-14, 19, 20, 122-7, 133-4, 254-8; see also endogenous margin

Hébert, R. F. 21

Hicks, J. R. 13

hoarding 193, 210, 219, 225

Holland 65, 116, 241

Hollander, Jacob 221-2

Hollander, Samuel 22, 248, 260

Hume, David 190

Huskisson, W. 122

ingot scheme 9, 270

interest rate 107-10; declining 64-6, 109-10, 128-9, 131, 245, 259;

see also growth theory

inverse wage-profit relation 2-4, 9-14, 20, 24, 168-9, 255-8, 268, 281

Jevons, W. S. 13, 17

Keynes, J. M. 220

Knight, F. 20-1, 114, 117, 218, 252

Koolman, G. 21, 252-3

Kuhn, Thomas 14

Kurz, H. D. 15, 19 labour theory of value $2-5,42-3,75$

land scarcity see growth theory

Lange, O. R. 8

Lauderdale, Lord 17, 147, 186, 204, 219

Law of Markets 7-10, 20-4, 64-5, 122, 128-9, 189-225, 247-8, 259, 263-4, 279; see also Say's Law

Leontief, W. 234

limits to production $122-5,212-14$, 216-18, 263-4

Link, A. N. 21

luxury expenditure 219

McCulloch, John Ramsay 13, 21, 131, 139-41, 142, 174, 263; his attitude towards Say 278-9, 289-92; commends Say's Smithian policy orientation 278; his Discourse reviewed by Say $112-13$, 252; and inverse wage-profit relation 5, 256-7, 268, 281; and 'New School' 104, 120, 132-3, 136; literature on Say's attitude towards 18; on methodology 238-41, 263, 287-8; on rent 139-42; see also Say, Jean-Baptiste

Magnan de Bornier, J. 23

Mahieu, F.-R. 20

Malthus, Thomas Robert 3, 6, 66, 72, 73 , 74-5, 122, 141, 212-14, 224, 227, 231, 248, 263, 265, 267, 271, 274, 277, 280, 283, 290-1; and classical canon 10, 11-13, 15, 17-18, 33, 127; commends Say on excess commodity supply $207-8$; his concern with excessive saving 66 , 203-4, 206; his corn-price analysis 45-6; criticizes Say on utility 105-6; identifies cost-price theory and Say's services doctrine 59, 90, 163, 250; on method 248; misunderstands Ricardo's labour theory of value 3,42 ; on rent $51-2$, 53-4; on Ricardo's contrast gross and net revenue 69-70; see also Say, Jean-Baptiste

Mangoldt, H. K. E. von 21

Marcet, Jane 291

marginal conditions $73,78-81,83,105$, 237

Marshall, Alfred 13, 22-3, 34, 99-100

mathematics 234-7

mercantilism 91, 190 
methodology 227-49; see also Say, Jean-Baptiste

Mill, James 13, 22, 52, 72, 74, 173-4, 227-8, 263; commends 1803 Traité 276; on the Law of Markets 195, 203 , 219-25; unimpressed by Say's Notes on Ricardo's Principles 69, 285-6

Mill, John Stuart 9, 26, 88, 135, 174, 198, 246; and capital accumulation 7, 176, 254; his conciliatory position regarding Say 24, 226-7, 264; on equation of demand and supply 101; his interpretation of Say on Law of Markets 22; his methodology 241, 243; rejects 'Treasury View' 189, 203, 247; on wage differentials 243

money: as medium of exchange 203; as precautionary reserve 202; excess demand for 8, 21, 190, 207, 209-10, 225, 247; see also excess commodity supply; Law of Markets

Montesquieu, C. L. 290

national debt 265-6

'natural' price 11-12, 32, 41, 58, 62-3, 81, 90, 250, 262

Notes on Ricardo's Principles see Say, Jean-Baptiste

O’Brien, D. P. 15-17, 234, 287

paradigmatic conflicts see Say, Jean-Baptiste paradox of value 98

Petty, Sir William 20

physics 233, 234, 236

Physiocratic theory 12-13, 54, 68, 91, 155, 164, 177, 191, 219-20, 251, 271, 290

physiology 233

policy 14-15, 22-3, 226, 247-8, 264-6, 278; see also gains from trade 'political arithmetic' 231-3

Political Economy Club 279 population 12, 15, 43-4, 51, 67-70, 125-8, 242, 256; see also growth theory; 'subsistence wage'; wage path

Potier, J.-P. 18-19, 250

Prinsep, C. R. 57, 62, 81, 91, 93, 263, 279, 289 productive services see services, doctrine of profit rate see interest rate

profit-rate uniformity 4, 17-18, 40-2, 60-3, 113, 130-1, 241, 243, 245-6, 252

protection 40-2, 58, 65; see also gains from trade

Prussia 211

pseudo-costs 18, 95-6, 121, 131

public works 91, 247-8

quantity theory 7

Quesnay, F. 13, 271, 290

\section{Read, Samuel 287}

rent: as cost 46-7, 50, 59, 109, 118, 131, 137-8, 268, 275, 281; as demanddetermined surplus 47-8, 53-4, 83, 96, 131-4, 139-41, 259, 270, 272; differential 2, 50, 56, 76, 83-5, 118-19, 131-4, 135-7, 138-9, 254, 270, 286, 290; and Say's neglect of intensive margin 52-3, 142, 270, 272, 283; zero at extensive margin $47,49,51-2,54,56$, 83-4, 119, 133, 138, 142-3, 254, 270; see also agriculture; diminishing returns; endogenous margin; Say, Jean-Baptiste

Revue Encyclopédique 112-13, 233-4, 241, 252, 272, 287

'Ricardian Vice' 23, 237-8, 247-8

Ricardo, David:

analysis: of aggregate-demand contraction as accompaniment of depression 21, 225; canonical 1-11, 14-15; of effects of taxation on aggregate activity 179-84, 207; of limits to production 263-4; a Marshallian perspective on value determination 13, 20, 99, 106, 141; of 'riches' summarized 151-2, 185-8; of scarcity principle in pricing 78 ; of tax incidence 34-6

his Essay in Profits 4, 12, 265

literature on his relation with Say 15-23 his Principles: the chapter 'On Gross and Net Revenue' 68-70, 178-9, 260; character of 22-3; debt to The Wealth of Nations 11

his Proposals for an Economical and Secure Currency 270 
on Say: his attitude towards 276-8; disparages the Lettres à M. Malthus 73-5, 277-8; disparages the Notes 278, 285-6; emphasises inconsistencies 64, 72, 74, 192, 212; identifies the services doctrine with cost-price analysis 32, 58-9, 76, 86, $90,178,250$; opposes view of agriculture as most productive sector 54-5, 259-60; protests at neglect of intensive margin 52-3; recognizes Say's priority over James Mill regarding Law of Markets 222-3

see also Say, Jean-Baptiste

'riches' 23-4, 145-71, 185-7, 254, 263, 275-6, 281

risk 20-1, 107, 113-14, 117, 218, 252; see also uncertainty

Robinson, Joan 17

Samuelson, Paul 10, 13-14, 135

'savings-is-spending' theorem 191, 194, 203-4, 218-20

Say, Jean-Baptiste:

his analysis: his concepts of demandsupply equilibration and of capital accumulation admired by J. S. Mill 101, 176, 254; his Marshallian perspective on value 20, 99-100, 106; objects to Smith's value-in-use 274; and organization of the Traité 88, 254; outstanding contributions regarding: aggregate demand contraction as cause of depression 21, 225, consumer surplus 99-100, 237, equality of marginal-cost and marginal-utility ratios $73,78,81$, 105, 237, objections to 'Treasury View' 189, 202-3, 207, 247, tax-incidence 34-6; paradigmatic conflicts 24, 64-5, 212, 258-61; priority over James Mill for Law of Markets 219-25; the 'pyramidical' structure 102-4 and classical canon: his adherence 25-30, 34, 40-2, 46, 57-63, 65, 67, 85, 90-1, $94,106,119,125-7,129,173-4,250$, 251, 254, 254-8, 263-6; attributes features of growth model to Adam Smith 119, 135-6, 139, 255, 266; aware of Ricardian's recognition of endogenous margin 132, 139, 141; claims precedence over Ricardo for central features of growth model 119, 132-3, 135-6; commends Ricardo's monetary principles 133, 209, 267, 270-1, 284; his empirical version of diminishing returns 126-7, 255; recognizes identitiy of canonical-cost and his services doctrines 76,250

and economic policy: approach to British corn laws 264-6; champions Smithian perspective 259-60, 278; and government intervention 91, 247-8; shares Malthus's view of desirable income distribution 103

his Malthusianism: basis for corn-price analysis 43-5, 51, 141-2; and hard-line approach to wage-rate determination 20 , 43, 70, 106

and methodology: his approach to applied economics 236-7, 241-4, 247-8; his case for deductive procedures 229-31, 233-4, 239-44, 248; on quantifiability as sine qua non of science 79, 254; and role of mathematics in political economy 234-7

his personality and personal relations: belittles Malthus's contribution to population analysis 283; charges McCulloch with plagiarism 241, 287-8; charges Ricardians with ill will 281-2; expresses himself too strongly 21; gives impression of systemic discord with Ricardo 262-6, 276; insists, against Ricardo, on novelty of his approach to 'riches' 144, 151-2, 167, 185-8; late modifications to his correspondence with Ricardo 158, 273-6; literature on his relation with Ricardo 15-23; his Notes on Ricardo's Principles 9, 23-4, 30-55, 285-6; protests at Ricardo's misunderstandings 78-9; rejects McCulloch's analytical claims on behalf of Ricardo 132-3, 136, 141-2, 266, 271-2; reviews McCulloch's Discourse 112-13, 252, 272; his sensitivity to criticism 24, 279-83; tends to misread Ricardo 42, 263-4; unfairness in retreat 263, 283; vicissitudes in his attitude towards Ricardo 18-19, 86, 129-43, 
266-82; his word-mindedness illustrated 32-4, 42, 62-3, 131-2, 140, 141, 259, 272

Say, Louis 161-2, 186

Say's Law 195, 213, 254, 264; see also Law of Markets

Schoorl, E. 16

Schumpeter, J. A. 13, 16-17, 21-3, 98, 237, 247-8, 251, 263

Scotsman, The 279, 289-92

Senior, Nassau William 13

service-supply conditions 106-18

services, doctrine of: 17, 23, 58-63, 76, 81-2, 84-5, 86-90, 105, 135, 151, 159, 163, 167, 178, 183, 202, 222, 250, 251; see also cost price

Sismondi, J. C. L. Simonde de 9, 22, 52-3, 89, 91, 123, 155, 175, 206-9, 215-16, 222, 227, 229, 242, 267, 283-4

Smith, Adam 4, 21, 68-9, 107, 108, 129-30, 151, 186, 190, 194-5, 278; on agriculture and investment priorities 24 , 54, 259-60; on corn pricing 43-5, 154; his doctrine of saving 10, 191-2, 204-5, 219-20; and effect of wages on prices 24; and 'competition of capitals' 10, 24, 64-6, 109, 123, 128-9, 191-2, 212, 223, 224, 245, 258; and land-based growth model 10, 119, 135-6, 139; opposes 'inductive' method 232; on productive and unproductive consumption 203, 204-5; on productive and unproductive labour 173; on 'riches' 148-9, 160, 166, 169, 229; on risk 117; his value theory $13,17-18,32,33-4$, 47, 77-8, 104-5, 274; on wage differentials 119-20, 131; his The Wealth of Nations 10-11, 25-6, 31, 107, 111, 140, 165, 170, 204, 255, 258, 270, 289; see also Say, Jean-Baptiste

Soliani, R. 19

Sowell, T. 23

Spence, William 219

Sraffa, Piero 13, 20, 273

stationary state 122-7, 255-6; see also growth theory; 'subsistence wage'; wage path statistics, use of 231-3, 240

Steiner, P. 18, 20-1, 249, 266

Stigler, G. J. 98, 222-3

stock vs. flow 24, 150, 157, 161, 162-3, 187,275

Storch, H. F. von 114, 176, 229, 236, 260, 288

'subsistence wage' 67-70, 106-7, 127-8, $131,134,254$

surplus 9, 12, 19, 68-70, 172-3, 177-9

taxation 35-6, 39-40, 46, 49, 53-4, 163-4, 179-84, 200, 207-8, 214, 264, 279, 281 technical change 91, 94, 99, 127, 147, 156-61, 166-8, 247-50, 281-3

Thornton, Henry 228

Tooke, Thomas 112, 250

Torrens, Robert 10, 13, 291

Tosi, G. 23

'Treasury View' 202-3, 210, 247, 254

Trower, Hutches 6, 74, 223, 267, 277, 285

Turgot, A. R. J. 175, 210

uncertainty 20-1, 199, 218, 252; see also risk

utilitarianism 69

utility 12, 28, 58, 70-5, 79-81, 91, 97-100, 104-6, 145-6, 159-61, 167-9, $173,187,250,263,290$

value theory 16-20, 70-9, 77-80, 83, 97, $100,105,148-9,157,160-1,165-9$, 227, 229, 275, 277-8, 280-1, 290; see also cost price; labour theory of value

wage differentials 76, 119-21, 235-6, 243

wage path 15, 65-6, 125-8, 258; see also 'subsistence wage'

wage-profit theorem see inverse wage-profit relation

Walras, Auguste 250

Walras, Léon 13, 251

welfare see 'riches'

West, Sir Edward 10, 13, 141, 255, 272

Wicksell, K. 13 